\title{
Principled Pragmatism \\ VOC Interaction with Makassar 1637-68, and the Nature of Company Diplomacy
}

Carl Fredrik Feddersen

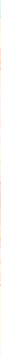

20 (1)

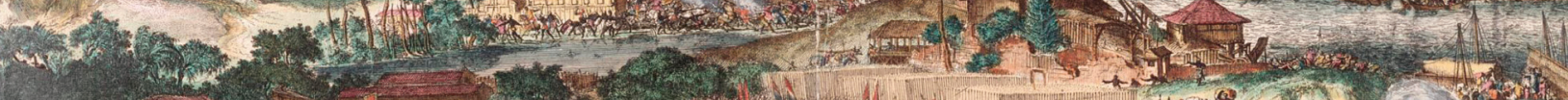

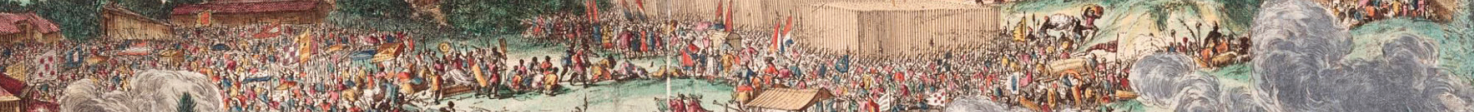

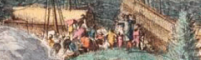

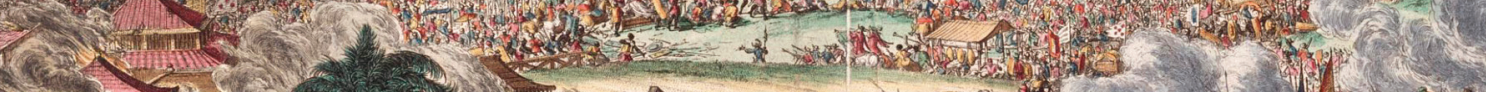

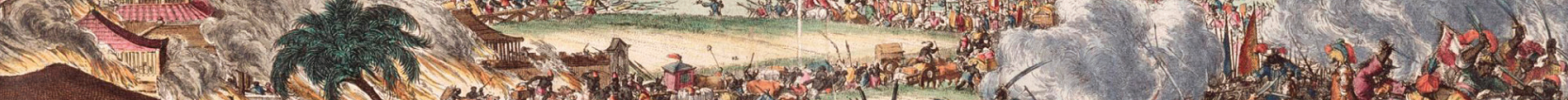

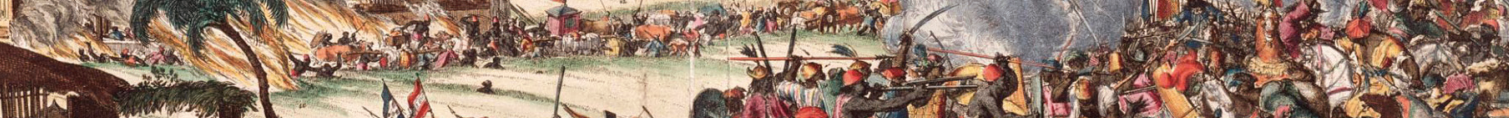

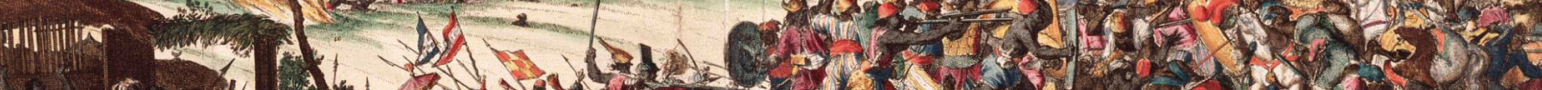

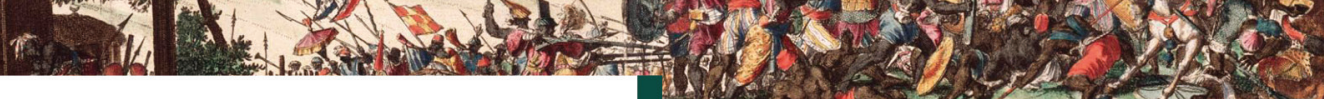




\section{Principled Pragmatism}

VOC Interaction with Makassar 1637-68, and the Nature of Company Diplomacy 

Carl Fredrik Feddersen

\section{Principled Pragmatism}

VOC Interaction with Makassar 1637-68, and the Nature of Company Diplomacy 
(c) Carl Fredrik Feddersen, 2017

ISBN: 978-82-02-56660-9

This work is protected under the provisions of the Norwegian Copyright Act (Act No. 2 of May 12, 1961, relating to Copyright in Literary, Scientific and Artistic Works) and published Open Access under the terms of a Creative Commons CC-BY 4.o License (http://creativecommons. org/licenses/by/4.o/). This license allows third parties to freely copy and redistribute the material in any medium or format as well as remix, transform or build upon the material for any purpose, including commercial purposes, provided the work is properly attributed to the author(s), including a link to the license, and any changes that may have been made are thoroughly indicated. The attribution can be provided in any reasonable manner, however, in no way that suggests the author(s) or the publisher endorses the third party or the third party's use of the work. Third parties are prohibited from applying legal terms or technological measures that restrict others from doing anything permitted under the terms of the license. Note that the license may not provide all of the permissions necessary for an intended reuse; other rights, for example publicity, privacy, or moral rights, may limit third party use of the material.

Cover painting: Romeyn de Hooghe, The conquest of Macassar 1666 to 1669, by Speelman From: the Atlas of Mutual Heritage and the Koninklijke Bibliotheek, the Dutch National Library. Credit: Wikimedia Commons.

Typesetting: Datapage

Font: Whitney \& MinionPro

The book is produced with support from University of Agder.

Cappelen Damm Akademisk/NOASP 


\section{Contents}

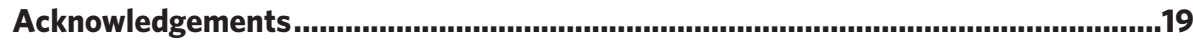

Summary, English ...........................................................................................21

1 Presenting My Case ............................................................................................ 25

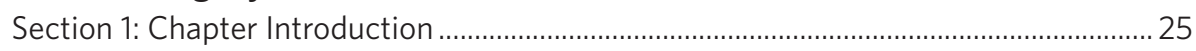

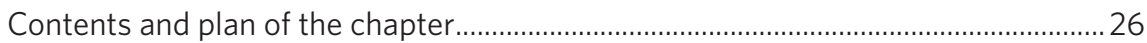

Section 2: A brief chronology of VOC-Makassar interaction, 1603-68 ........................... 26

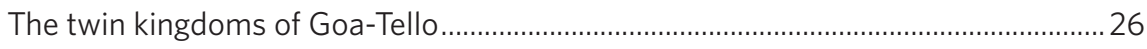

Actors in the Makassarese political field ...................................................................... 27

Internal tensions in South Sulawesi: The Bugis-Makassar dimension ........................28

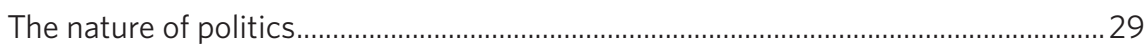

The role of Islam

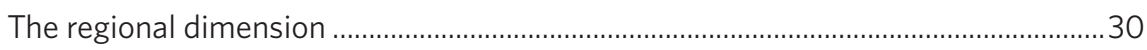

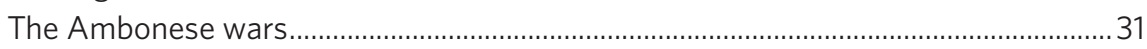

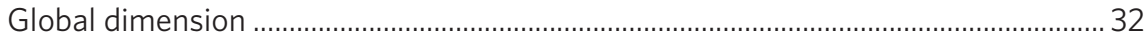

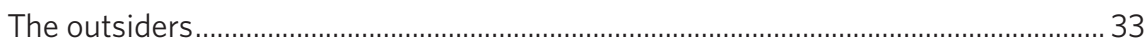

Chronological overview of the seventeenth VOC-Makassar interaction .....................34

The monopoly on nutmeg and cloves as the central issue of conflict .......................... 35

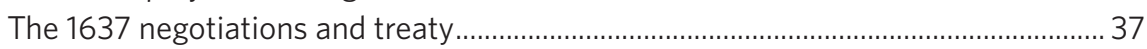

From the 1637 peace to war, negotiations, and the 1655 treaty.................................. 37

Tensions 1655-60, and another cycle of war, negotiations, and treaty........................ 38

Context and treaty making: The Bugis rebellion in 1660 ............................................... 39

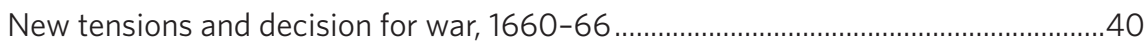

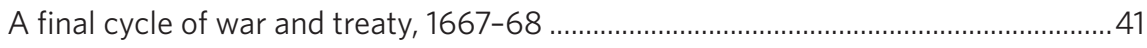

War on and in Makassar, June-November 1667 ........................................................... 42

Securing the peace by war and still more treaties, 1667-69 ...................................... 42

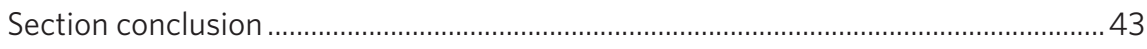

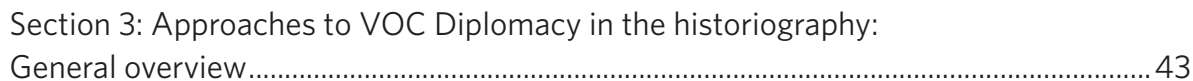

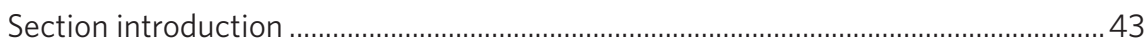

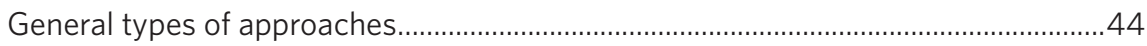

Section 4: Chronological overview of the historiography ............................................ 47

Nineteenth- and early twentieth-century historiography .......................................... 47 
The Van Leur break and the economic turn in the post-World

War II historiography

Revisionist comparative perspectives and views on the nature of interaction.......... 48

Entering a new millennium: The coming of a "new diplomatic history"? ................... 52

Jurrien van Goor's positions on Company diplomacy..................................................... 53

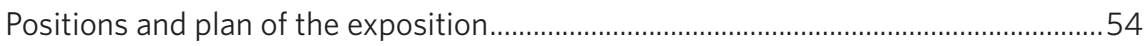

Van Goor's positions on the nature of the Company's diplomacy................................54

Van Goor's position on the Company's position in the overseas

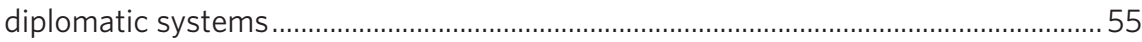

Accommodation as preferred interaction mode and its implications .......................... 55

Comparative aspects and the issue of commensurability ............................................56

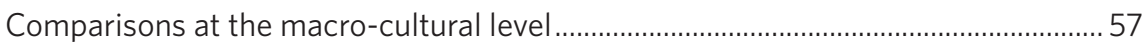

The singularity of my analysis compared to Van Goor's positions.............................. 59

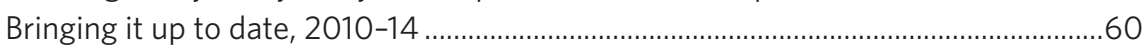

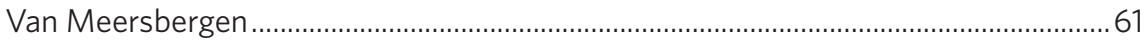

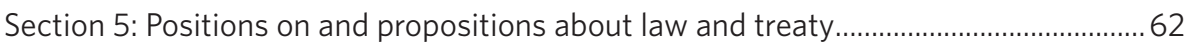

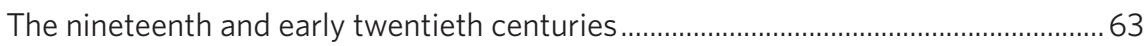

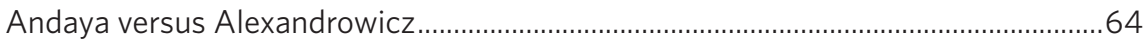

The Paulusz-Arasaratnam exchange on the Westerwolt Treaty ................................ 65

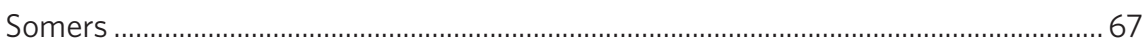

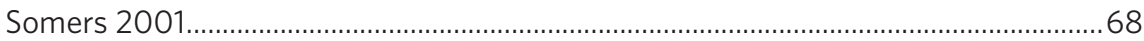

On the Company's assumptions and mode in its diplomatic

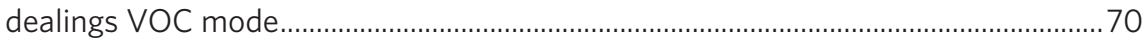

Somers 2005

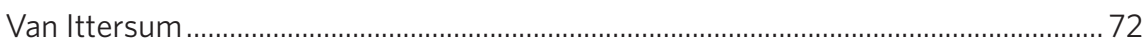

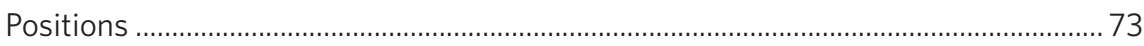

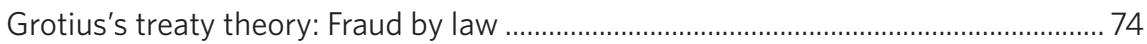

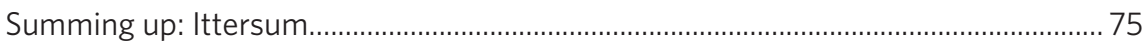

Section 6: Summing up the historiography of VOC diplomacy....................................... 75

2 Positions and Propositions Refined ........................................................................ 79

Section 1: Brief historiography on seventeenth-century Company-Makassar interaction, with an emphasis on Andaya's propositions ...................................................... 79

Spiritual versus secular conceptions of "treaty" .........................................................8

South Sulawesian and Western functions of treaty and function

of state-interaction systems contrasted

A spiritual conceptualisation of interstate relations: The workings of

the South Sulawesian system and grounds for structural misunderstandings,

and conflicting views on the nature and bonds of treaties

The concept of siri and the workings of diplomacy and treaty in the

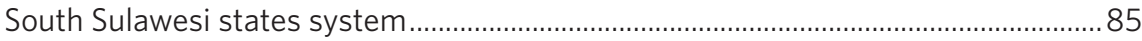

Miscommunication in treaty making between Makassar and the Company .............86

Exceptions confirming the rule in the Company's treaty practice ................................ 87 


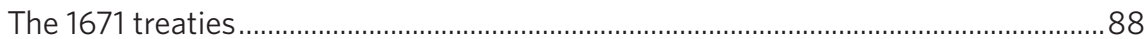

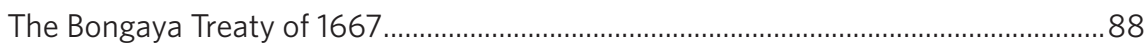

European tunnel vision and lack of understanding of and sensitivity to local perceptions in the Company's treaty making.................................89

Allegations of breach of contract as a cultural misconception ....................................90

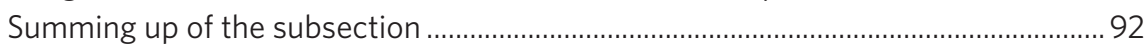

Andaya's views on treaty and treaty making in historiographic perspective............. 92

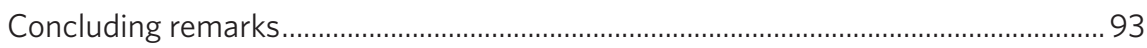

Section 2: Resink's proposition on international law in Makassar

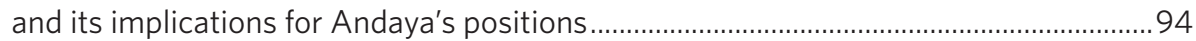

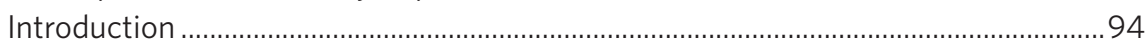

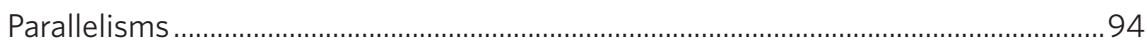

Institutions of international law in Indonesia................................................................... 97

The outsider as a separate category in the Indonesian

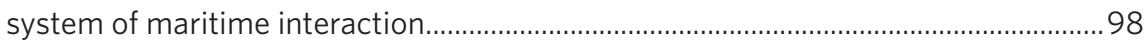

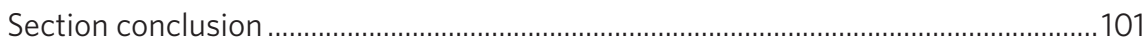

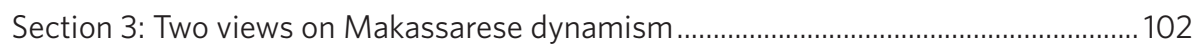

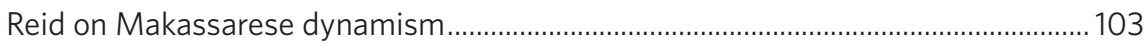

The nature of late sixteenth and seventeenth-century

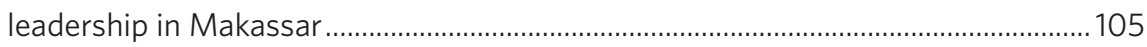

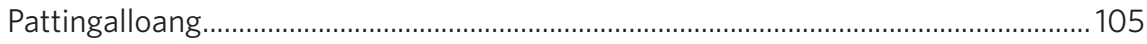

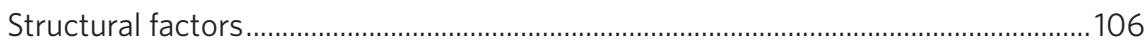

A seventeenth century cultural shift with "modern" implications? ............................ 107

Section 4: The structure of the argument .................................................................. 108

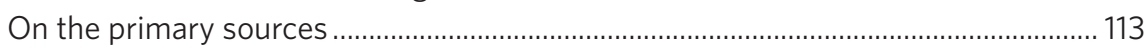

The nature of the primary sources and method .................................................... 114

\section{The model of overseas diplomacy in the Heeren XVII's}

Generale Instructies and the advice on Makassar in the particular letters .............. 115

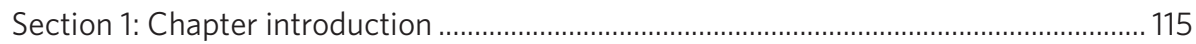

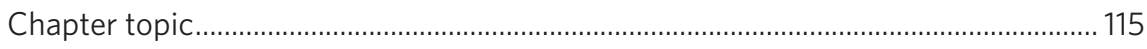

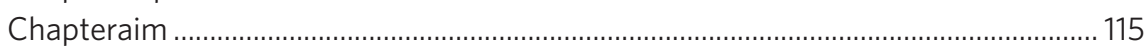

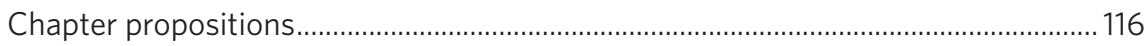

Two additional comments.................................................................................................. 117

A rebuttal to my critics about my interpretation of the role of

international law in the Company's diplomacy ......................................................... 117

The Role of Islam in Makassarese political thinking ........................................................118

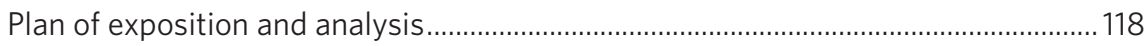

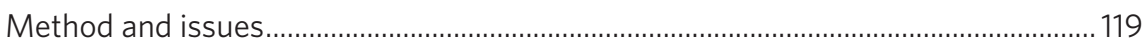

Section 2: The respective General Instructions 1609-50, and

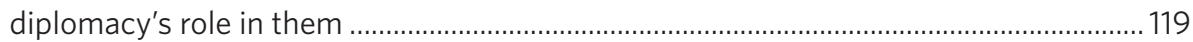

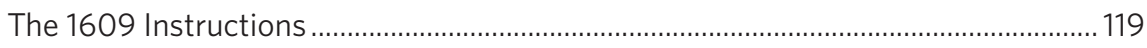

Issues, concerns, and diplomacy in the 1609 Instructions ........................................ 120 
The 1613 Instructions Context and general contents ...................................................122

General presentation of the contents in the 1613 Instructions....................................122

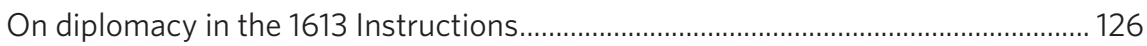

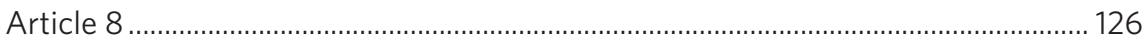

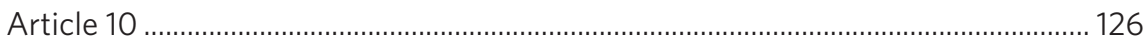

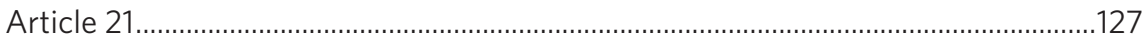

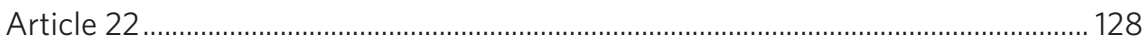

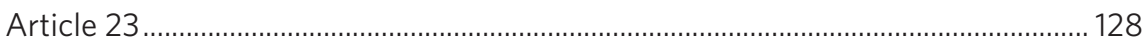

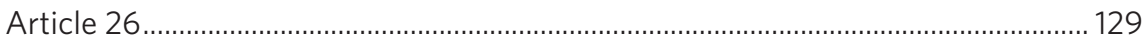

Article 33

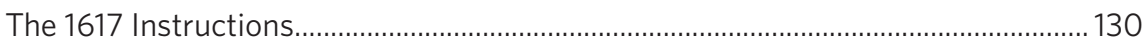

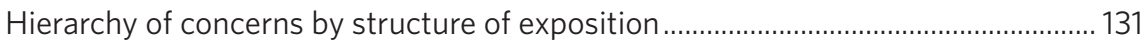

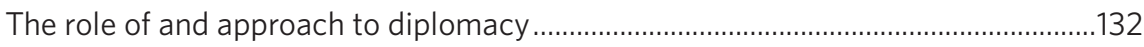

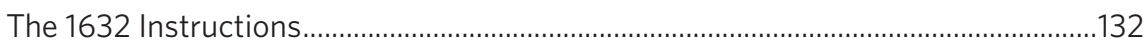

Contents and structure of the 1632 Instructions ……...........................................133

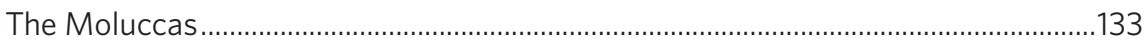

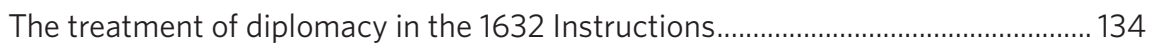

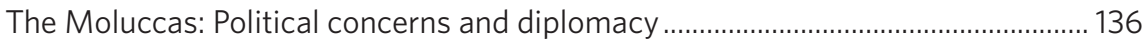

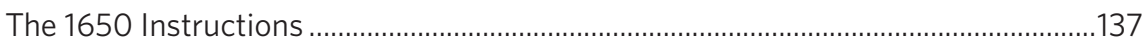

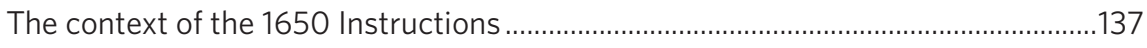

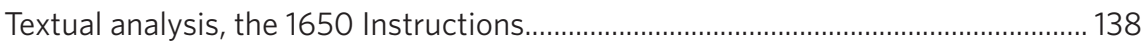

The balance between war and diplomacy regarding

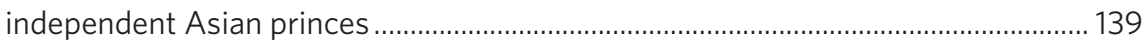

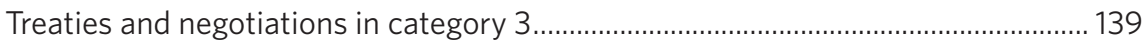

Adaptation, accommodation, and pragmatism as

the general principle in diplomatic interaction

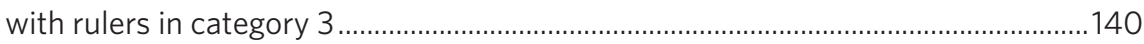

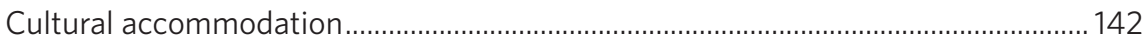

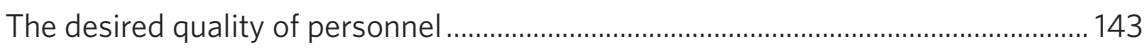

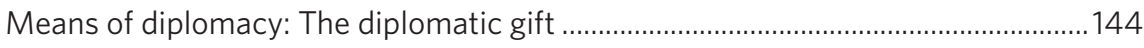

Notions of cultural relativism and pragmatic
accommodation to local ways in the pre-1650 General Instructions ........................144

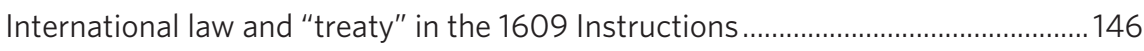

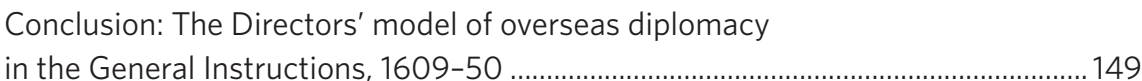

Section 3: Commerce, diplomacy, and ideology................................................................. 149

The Company's success as providential blessing .......................................................... 150

Section 4: Approaches to diplomacy in the entries on Makassar in

the particular patriase letters to the High Government 1634-1669 ............................... 154

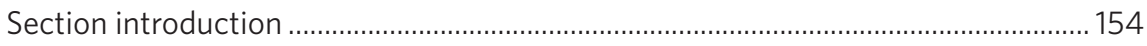

Letters containing politico-diplomatic implications or

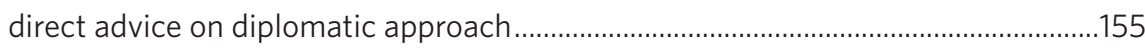


The nature of the Directors' advice on approach towards

Makassar in the particular patriase letters................................................................... 159

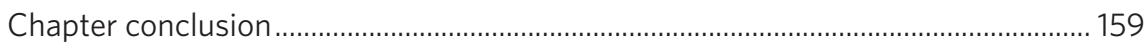

4 Culture and Treaty: Leonard Andaya's model of conflicting treaty conceptions and the June 26, 1637 treaty between Sultan

Alauddin and the Company .........................................................................................161

Section 1: Presentation of the June 26, 1637 treaty of peace between

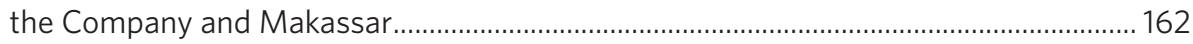

Background and context of June 1637 treaty .................................................................. 162

The nature of the 1637 treaty: Historiographic positions and

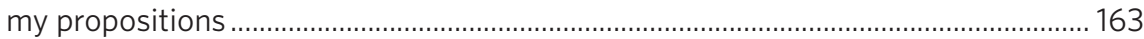

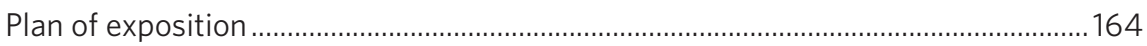

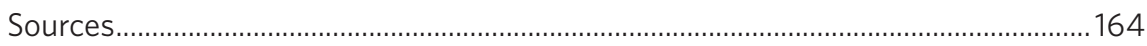

Section 2: Perspective in South-Sulawesian thinking on diplomacy

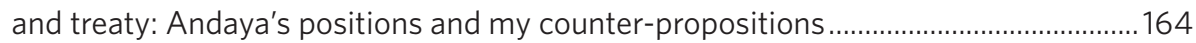

Andaya's structural approach to overseas treaty making ...........................................164

Local imprints in the Company-Makassar treaty record ............................................. 165

Andaya on the protection of sovereignty as a "typical

South Sulawesian feature," and its imprint on the 1637 treaty ................................... 166

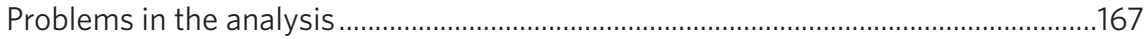

Alauddin's claim of perceptions of perpetuity as typical of the

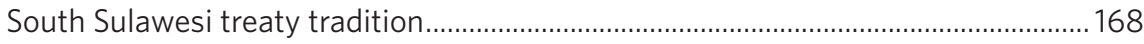

Antagonistic notions of "breach of contract" ................................................................. 169

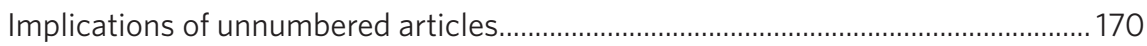

The swearing ritual as an example of local imprint .................................................. 171

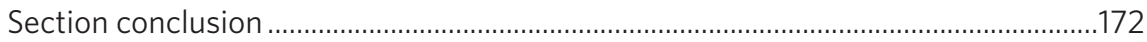

Section 3: The significance of communicative performance in

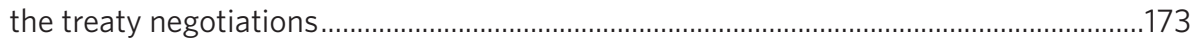

Brief chronology of events from June 22-June 26 and their implications ..................173

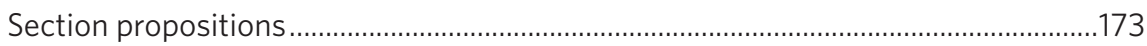

Events of June 22: Determining the sultan's intentions ................................................174

Events of June 23: The Achenese ambassadors as

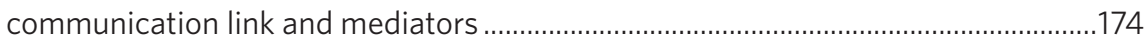

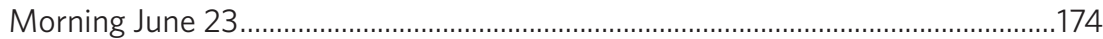

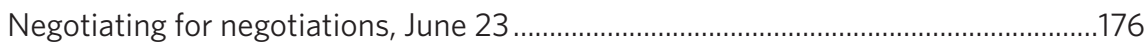

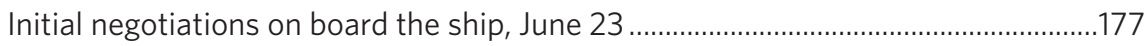

Events of June 24: A simple "misunderstanding"? ....................................................... 179

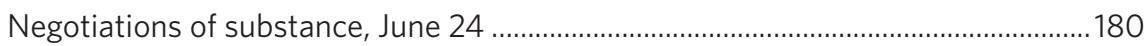

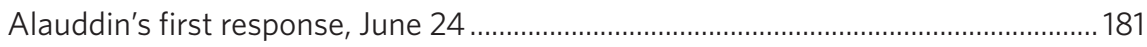

Dutch deliberations and swift response on the ship, June 24 .................................. 184

Alauddin's amendments and continued negotiations, June 25................................. 184 
Deliberations and decisions on Alauddin's amendments on board, June 25 .......... 186

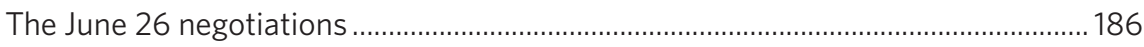

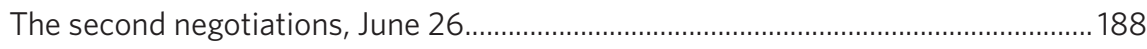

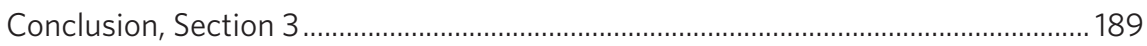

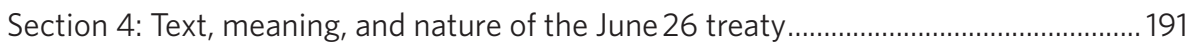

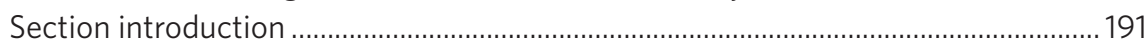

The typical Company treaty as opposed to the South Sulawesian

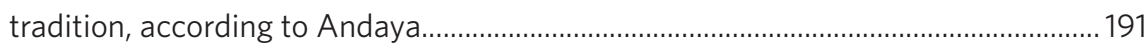

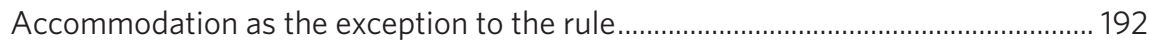

Andaya on antagonistic interpretative frameworks as the rule ................................. 193

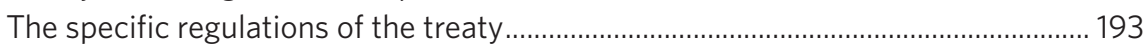

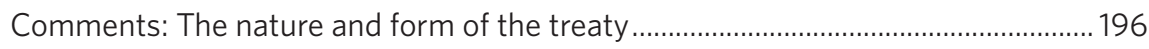

The issue of "sovereignty" ................................................................................................197

Explications and implications of secular, defensive "sovereignty" ........................... 198

Chapter conclusion: Treaty compromise by context and

meaningful communication, not cultural collision and

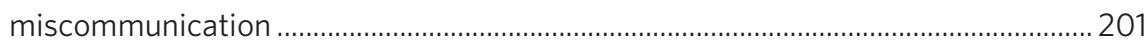

\section{Policy Discussions and the 1655 Treaty with}

Makassar-A Matter of Trust and Belief..............................................................203

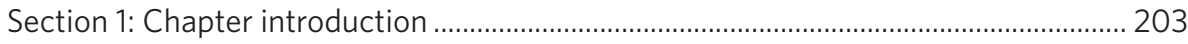

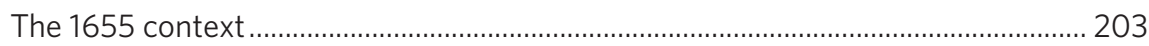

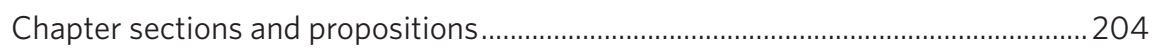

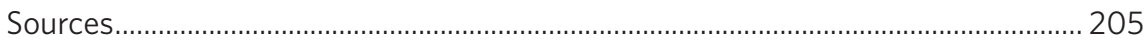

A comment on the Generale Missiven as a source for

understanding "overseas diplomatic culture" ............................................................ 206

Section 2: Conflicting assumtions of diplomatic performace 1650-1655 ...................... 206

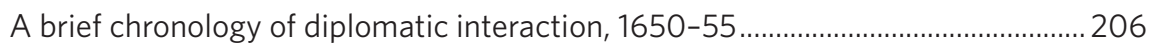

Makassar as a category 3 territory in the 1650 General Instructions ..................... 208

Implications in the Directors' advice on Makassar, 1650 ............................................ 210

Section 3: The De Vlaming-Maetsuyker Controversy Concerning

When to End the War: the shared pragmatic mode of thinking about

overseas diplomacy, and the assumptions in Maetsuyker's "

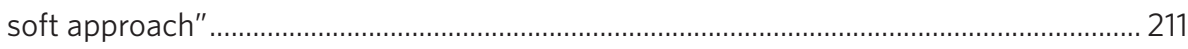

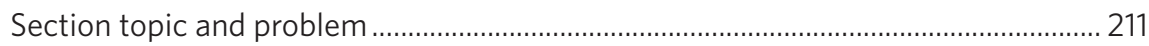

Presentation of the two contestants ................................................................................ 211

Maetsuyker: Career and historiographic evaluation ............................................... 211

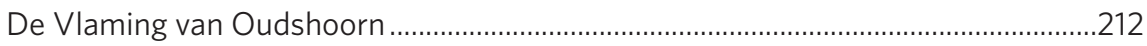

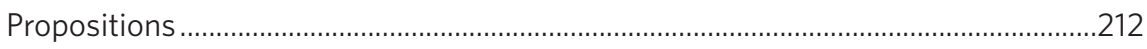

Textual analysis, Maetsuyker's advocacy for the negotiation

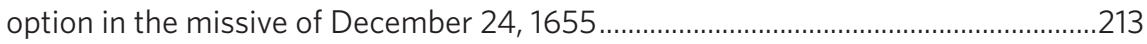

On De Vlaming's excessive use of force as counterproductive 
The basic assumptions in De Vlaming's argument for

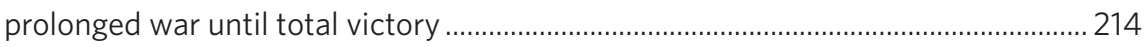

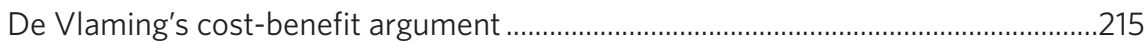

Maetsuyker on De Vlaming's cost-benefit argument for war ......................................215

De Vlaming and Maetsuyker on whether to trust the Makassarese .......................... 216

Maetsuyker's counter-arguments to De Vlaming's "grand strategy"........................217

De Vlaming's grand strategy for Makassar rejected-a matter of

differing expectations

Rejecting De Vlaming's war plan as costly, reckless and likely

counterproductive-advocating soft diplomacy as an alternative.

Opposing De Vlaming's grand strategy for its lack of

long-term realism

Arguing the lack of realism in the belief in obtaining local allies ................................ 219

Arguing permanent residency and information gathering by

way of treaty as opposed to war

The concluding appeal to the Directors

Considerations of context primary to considerations of law......

The significance of dismantled trust after 1655 and its

significance in interpreting the 1655 context.....

Opposing standpoints within a shared conceptual

framework - the source of differences in policy preferences.

Section 4: Analysis of the 1655 treaty as a typical product of

"soft diplomacy"

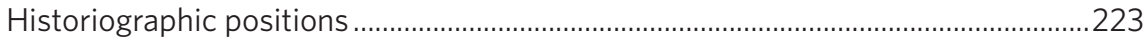

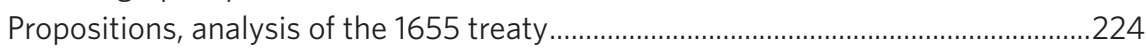

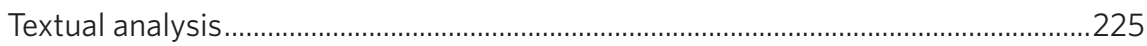

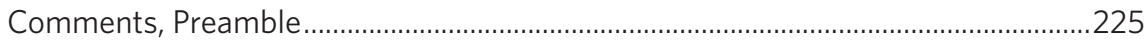

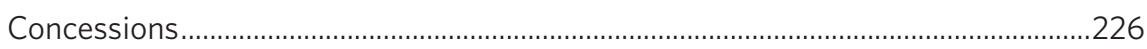

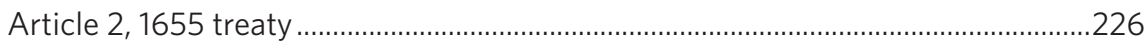

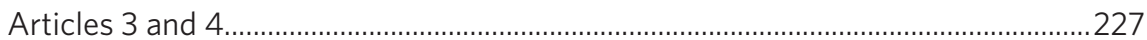

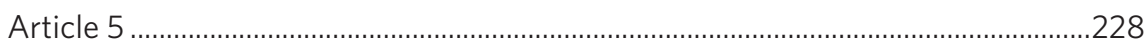

A brief speculation on Hasanuddin's use of the religious

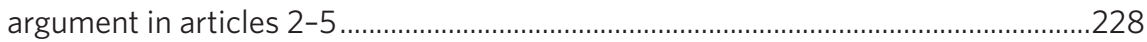

Prestige and religion as motives in Company diplomacy............................................22

Articles 6 and 7: Regulating relations with the Portuguese

and other third parties

Comments on the regulation of the Makassar-Company

positions in the multilateral interaction regime set down

in articles 6 and 7

Securing the Company's monopoly and Sovereignty by treaty:

Article 8

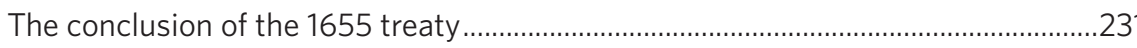

Chapter conclusion. 


\section{The Pragmatic Dynamics of the Batavian Diplomatic Mode-Shifts and Fluctuations in the High Government's Approach towards Makassar as Presented in the Generale Missiven, 1656-61}

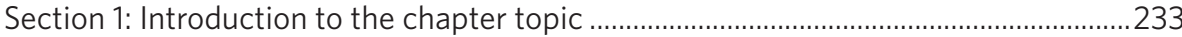

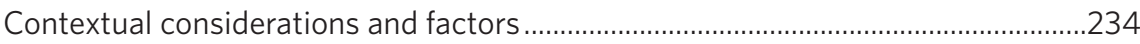

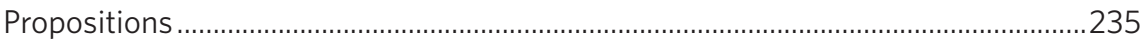

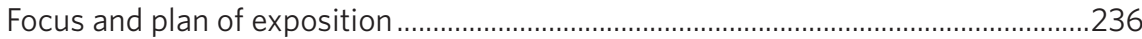

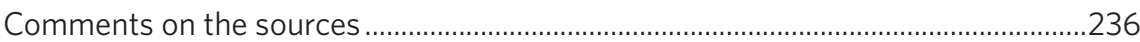

Section 2: The missive of December 4,

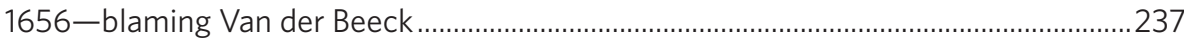

The 1656 context -the reversal of positive expectations of Hasanuddin .................237

Textual an alysis, Makassar in the missive of December 4, 1656 ............................237

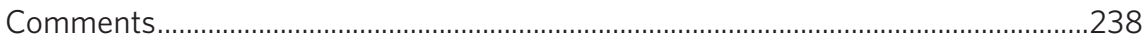

Summing up positions and their implications in the missive of

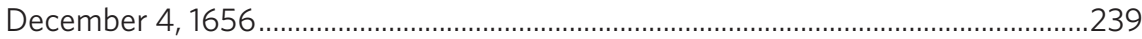

Section 3: The missive of December 17, 1657-full explication of

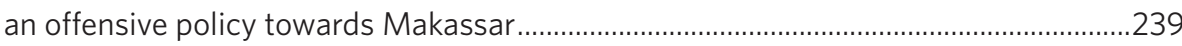

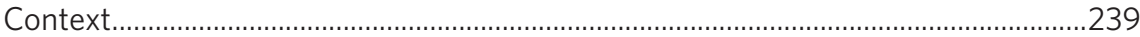

Makassar in the missive of December 17, 1657 ................................................... 240

Textual analysis, missive of December 17, 1657: Validating

Hasanuddin's hostile intentions and deceitfulness ..................................................... 240

Comment: The emotional aspect of the turn from trust to distrust..............................241

Explaining the probability of Makassarese plans for war

and conspiracy against the Company....

The commercial conspiracy, already at work ...............................................................242

The explanation of the post-1655 strategy ......................................................................243

Arguing the case for war by referring to the deceitful

nature of Hasanuddin and the Makassarese.

The presentation of Hasanuddin as an unreliable partner

in treaty making

Assurance of the commitment to fend off a Makassarese attack on

Ambon and Banda.

A return to, and turnaround of, the 1655 cost-benefit arguments

about war

Comment.

The argument concerning the excessive costs of war countered

Reassuring that the security of Ambon and Banda is not jeopardised

and arguing the soundness of the war plan.

Inscribing Makassarese deceit towards the Company as structurally

embedded

The cultural-religious argument. 
Comments 248

Summing up the break with the 1655 assumptions and positions in

the Generale Missiven of December 1656 and 1657 .................................................. 248

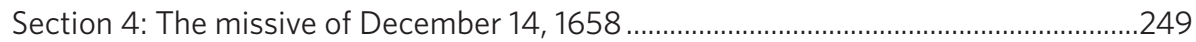

Context and focus

The fear of a Makassar-Mataram alliance, and the implications for the Spice Islands. 250

Deliberating on the nature of religion in Makassar's expansion efforts.................... 250

Comment.

The High Government's change of view on the mix and hierarchy

among the pursuits of power, prestige, and profit

Concluding the analysis of the December 14, 1658 letter:

The difference of tone in the 1657 and 1658 letters

Shared characteristics of the 1656,1657, and 1658 missiven

in contrast to that of 1655

Section 5: The December 16, 1659 missive: Reporting on

Negotiations with Low Expectations

The primacy of contextual considerations.................................................................. 254

The chronology of the Basting mission......................................................................... 254

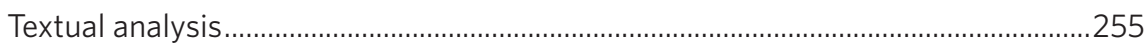

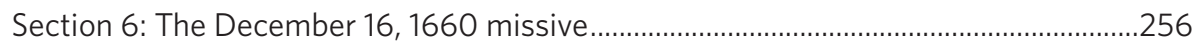

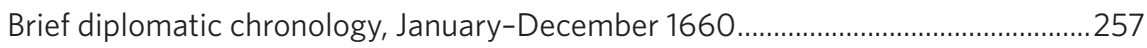

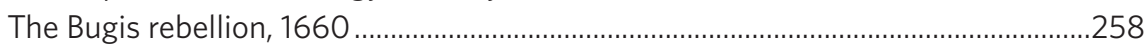

Topics and issues in the missive December 16, 1660 ...............................................258

The contextual imprint in the December 16, 1660 missive

on Makassar - and the slide from realism towards cynicism ..................................259

Textual analyses, the December 16, 1660 missive on Makassar:

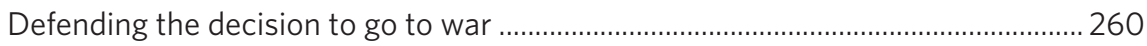

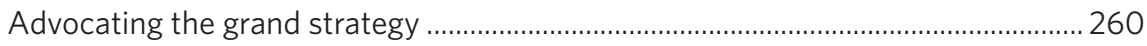

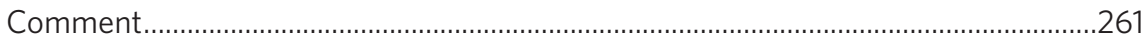

Policy preferences fluctuating as to information about context .................................261

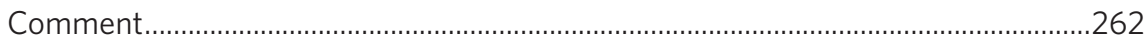

Bending treaty agreements on Fort Panakkukang in the hope of

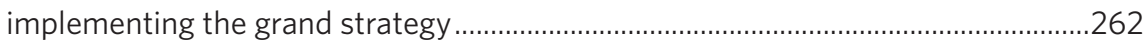

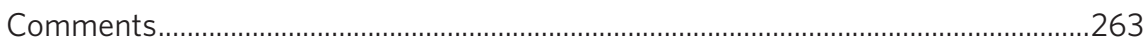

Section 7: The Missiven of January 26 and December 22, 1661:

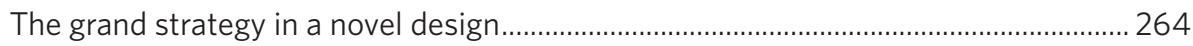

The plans for the post-1660 commercial regime and its political implications.............. 264

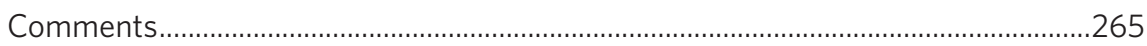

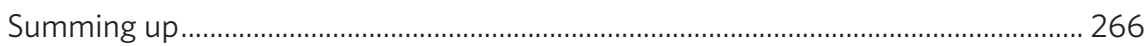

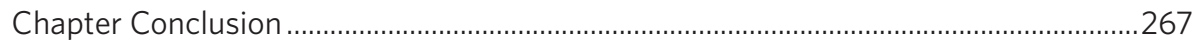




\section{Learning to contract, 1: From contractual regulations of interaction towards construction of a relational regime 1637-1660}

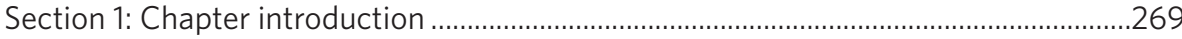

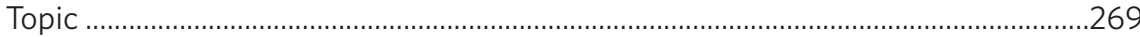

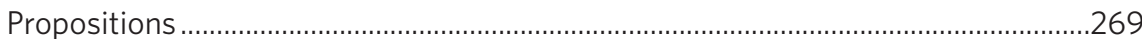

Continuities and breaks in the dynamics of treaty making .....................................270

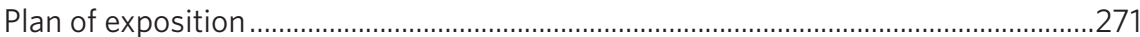

Section 2: A recapitulation of the 1637 and 1655 treaties as "soft" treaties....................271

The 1637 and 1655 treaties: Different, but still two of a kind......................................272

Section 3: The switch to contractual constructivism:

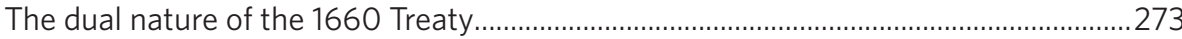

Section introduction: Topic and propositions.............................................................273

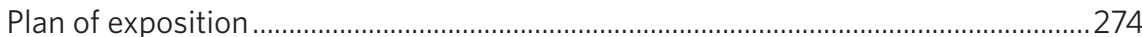

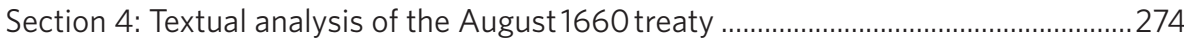

A treaty to be honoured, make no mistake about it ......................................................274

Reconstructing the political regime: 1-Limiting

Makassarese claims of sovereignty outside Makassar

to secure the Company's interests in the Moluccas (articles 1, 2, and 3) ................275

Comment: Idioms of "sovereignty" in articles 1, 2, and 3 and

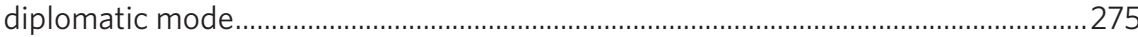

Issue: Ambon, the Spice Islands-banning interference and

restricting sailing rights (articles 4 and 5 )

Comments: A further turn towards treaty formulations in

the concrete and specific

Securing and protecting the Company's monopoly in the

Spice Islands (articles 6 -9)

Comment: constructing a defence for the monopoly by treaty .................................279

Power politics and the expulsion of the Portuguese (articles 9-12) .........................279

Articles 9-11: Neutralising the threat from the Portuguese in

Solor and Timor and making it a general rule 280

Summing up: Restrictions on Makassar's foreign policy and autonomy in the precautions to protect the monopoly

The expulsion of the Portuguese (article 12)

A proposition for a reconfiguration of Makassar-Company

relations following the expulsion of the Portuguese

The blame and shame in damages and debt:

1-Implications of prestige distribution

(articles 13-15 and 18)

Article 13

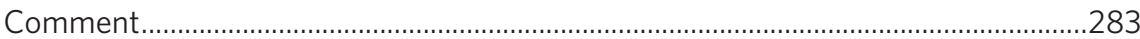

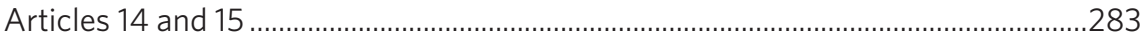

Courting Makassar in distrust: Articles 23-26 ......................................................... 284

Article 25: Evacuation of Fort Panakkukang ................................................................28 
Correcting the mistakes of 1655: Regulations on runaways and converts (articles 16 and 17).

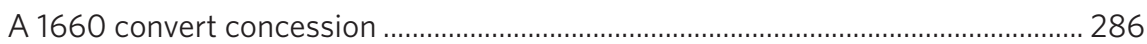

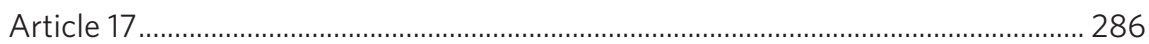

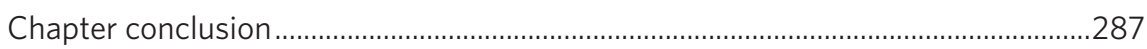

8 Learning to Make Treaties, Two Treaties of Political Hegemony, 1667-68 .......289

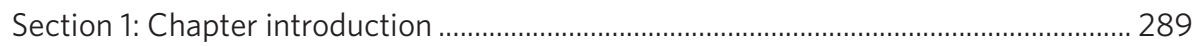

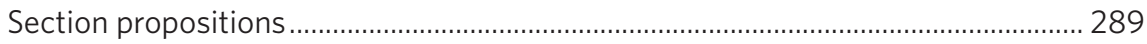

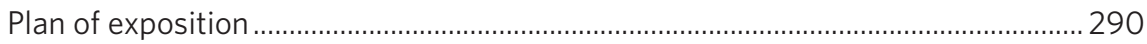

Section 2: The outer islands treaties January-June 1667:

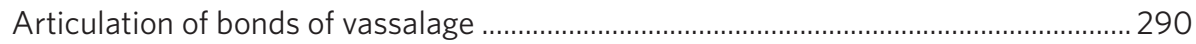

Buton as an exception confirming the rule ....................................................................... 291

Securing political dominance and stability in Buton by

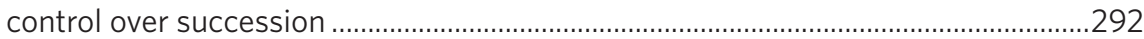

Conclusion: Buton and the other outer islands: Exception and rule...........................293

The meaning of sequence ............................................................................................. 294

Section 3: Company hegemony in the November 18, 1667 treaty

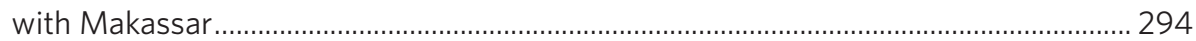

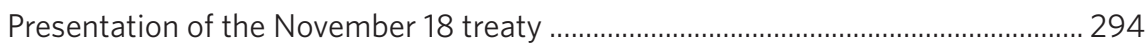

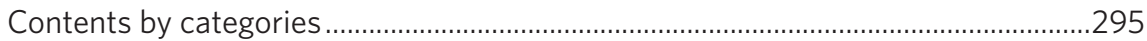

Hegemony in the explicit political regulations of the 1667 treaty:

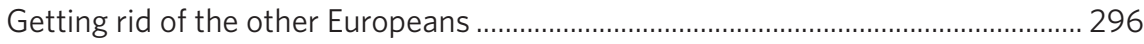

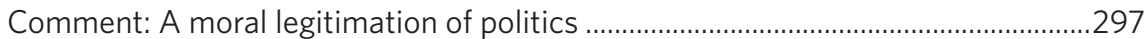

Comment: form and content in the exclusion articles.................................................. 298

Article 10: The regulations for military backup and security ..................................... 298

The outer security circle: Bima ……............................................................................ 299

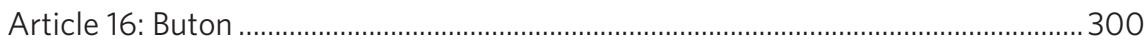

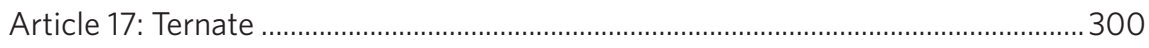

Summing up and comments: The articles cutting bonds of

alliance to the Makassarese and transferring them to the Company......................... 301

Section 4: Restructuring the political geography of

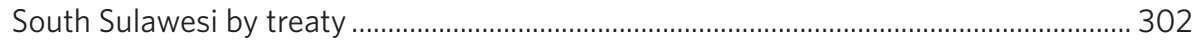

Article 18: Rewards to the Bugis allies and Makassarese

recognition of autonomy for Bone and Loeboe........................................................... 302

Article 19: The punishment of Laijo and Bancala for siding with

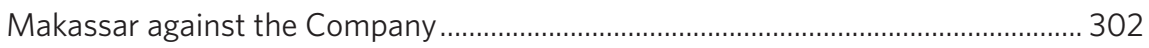

Article 20: Elaborating territorial rearrangements as legitimate

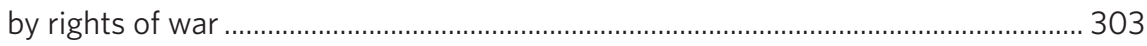

Summing up: Transfers of sovereignty and territory ............................................... 303

Sanctions against local petty states that had sided against

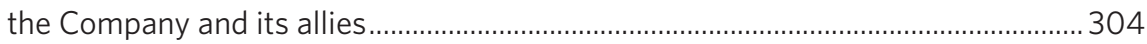

Configuring the respective polities into a hegemonic system (articles 23-25)..... 304 
Article 23: Reconfirming the Company's political hegemony

Article 24: Incorporating Makassar's vassalage position into the

new local and regional treaty system.

Article 25: The hierarchy of hegemony

Summing up: The Company as hegemon by treaty..................................................307

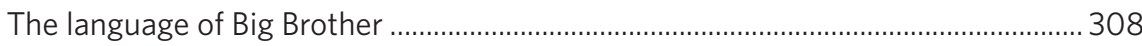

Section 5: The 1668 treaty with Tello: Paternalism as the

cement of loyalty

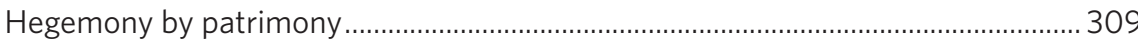

Section conclusion: The 1667 and 1668 treaties of hegemony .................................... 310

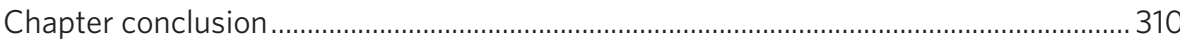

\section{The Pragmatic, Empirical Model of Overseas Diplomacy}

\section{in Cornelis Speelman's Notitie}

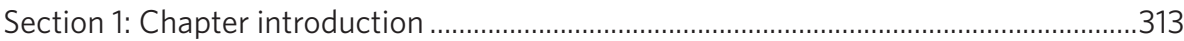

The challenge of preserving the Company's hegemony by diplomacy ......................313

Section 2: Cornelis Speelman, a brief diplomatic- military biography............................. 314

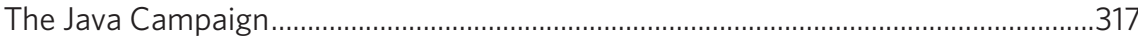

The conquest of Banten....................................................................................... 319

Preliminary negotiations: The issue of letters of delegation ..................................... 320

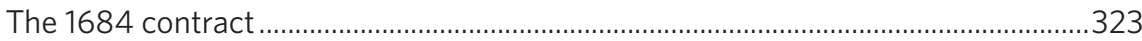

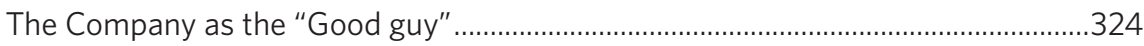

The other foreigners in general and the English in particular as

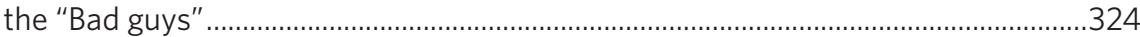

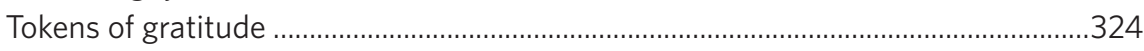

Section 3: Analysis, the Notitie On the Notitie as a source for

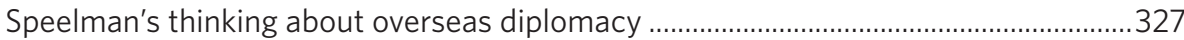

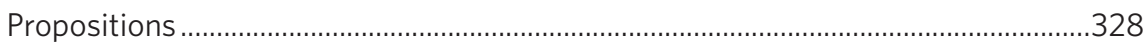

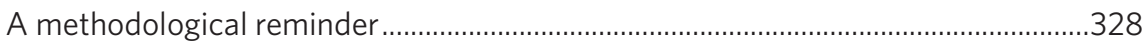

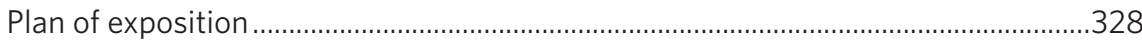

The limitations of treaty agreements in upholding the hegemonic regime .............329

Speelman's account of the Company's interaction with Makassar

up to 1666 -the relative value of treaty regulations to military sanctions............... 330

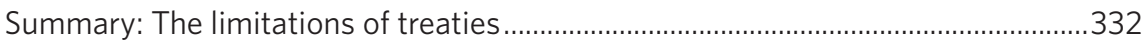

On diplomacy's role in upholding the Company's hegemony in general .........................332

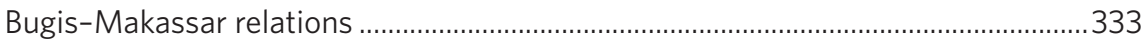

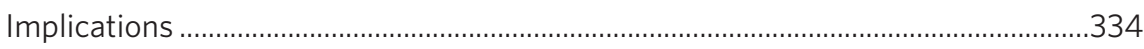

The importance of acquiring precise information on local conditions as the general foundation of the Company's diplomatic performance.................................334

Considerations with respect to the foe: Karaeng Karunrung .............................................336

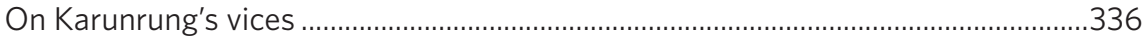

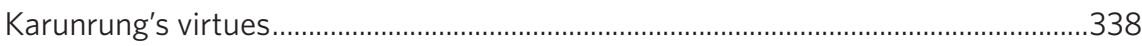

Luring Karunrung over to the Company's side..............................................................339 
The young king of Makassar. 340

A shared implication in Speelman's characterisation of

Karunrung and the young sultan of Makassar.

The king of Tello

Advice on how to approach the king of Tello.....

Summing up: The implications of Speelman's assessments of the Makassarese foes

A return to the information dimension.

Three aspects of keeping the alliance with Arung Palakka......

Legitimacy by dynastic claims and historical tradition................................................. 346

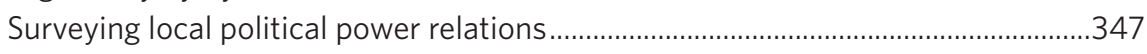

The concern over Arung Palakka's lack of legitimate heirs ....................................... 349

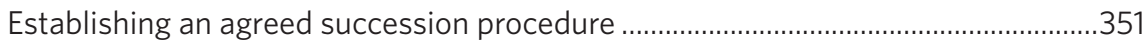

Arung Palakka's personal charisma and the hazards of going

public with his religious speculations

Speelman's handling of the two obstacles and the diplomatic

mode of empirical pragmatism.

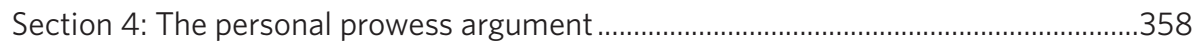

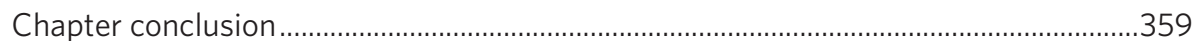

Thesis Conclusion...................................................................................................... 361

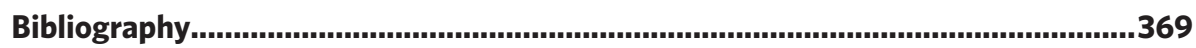

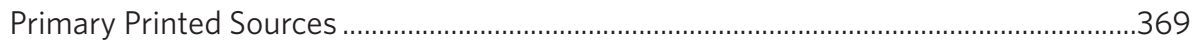

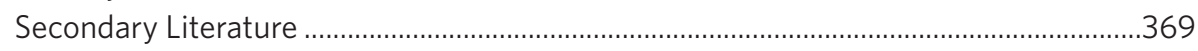





\section{Acknowledgements}

This book is a revised version of my doctoral thesis submitted to the University of Leiden September 2016. I have revised the text with a special focus on some of the points and objections that were raised during the promotion, such as the role of religion in the politics of Makassar, the role of international law in the diplomatic thinking of the Company; and enlargement of the historiographic section with a special eye to the treatment of Jurrien van Goor.

The thesis has a long history, beginning with my approaches to Professor Leonard Blussé in the spring of 1996. For a number of reasons - some of them having to do with health - some of them with teaching commitments - it has taken me over fifteen years to complete the work. Over these years, four institutions have made this possible. First, I would like to thank the Research Council of Norway for awarding me a Doctoral grant for the years 1997-2000. Second, I would like to thank the Department of History of Leiden University and the International Institute for Asian Studies (IIAS) at the University of Leiden, where a grant enabled me to stay as a guest researcher from 1997-98.

Returning to Norway, my ability to work was hampered by health problems over longer periods. This situation was relieved by the University of Agder's willingness to lighten my teaching load, and this meant that I finally could finish the thesis. I would like to thank the University of Agder for that and especially the then Dean at the Faculty of Letters at that time, Ole Letnes.

Professor Leonard Blussé, who is something of an institution all by himself, has guided me through this work with a mix of scholarly suggestions and friendly scolding. He possesses a unique ability to never miss an opportunity for presenting anecdotal digressions, where the digressions, paradoxically, were always to the point. If it were not for Professor Blussé, there would have been no thesis. And, had there been no Blussé, it would not have been half the fun writing it. 
Many of the people that I met during my year in Leiden have become good friends, and more than they probably know, they have been a great support. So, a big thank you and a smile go to Martha Chaiklin, Cynthia Vialle, and Paul A. Van Dyke. Lincoln Paine corrected my first English draft, and later proofreadings have been conducted by translators from the Portal Publishing House of Kristiansand. Thanks go to them too.

A special thank you goes to Editor Lars Aase at the Cappelen Damm Akademisk for helping and facilitating in the process of publishing my thesis.

At the beginning of the writing of my thesis, and over the years, I have contacted a lot of people for advice. I have never met a person in this field who has not been forthcoming and helpful. All deserve my thanks, but I would like to mention two especially, Professor Jurrien van Goor of Utrecht University, who perhaps without knowing it, helped me pursue the matter, and Professor John E. Wills Jr., who helped get the project back on the right track at a time when it might have crashed. I have also over the years been in regular contact with Professor Peer Vries, and although we have not discussed my thesis in particular, our exchanges on global history have influenced my thinking about history.

A few words must also be said about Agder University and my colleagues there. I am grateful for having had the opportunity to discuss drafts of chapters with my colleagues at the History department. Special thanks go to Professor May-Brith Ohman Nielsen in this connection for her observant reading and to-the-point comments. Professor Ole Riis must also be included in this special list. I appreciated his merciless critical enthusiasm! Special thanks go to Professor Jonathan Baker, for his encouragement during more than three decades.

Finally, I would like to thank my three daughters, Kate, Frida, and Birgitte Maaike, first for just being there, second for never asking why I kept on doing this and just accepted that my writing about the Dutch and Makassar was a basic fact of our family life. And not only that; as the work finally started rapidly progressing, they showed genuine enthusiasm for it!

Last but far, far from least: My thanks for supportive understanding go to my love, Ruth Wangberg. 


\section{Summary, English}

This thesis explores the nature of VOC diplomacy using the seventeenth century interaction between the Company and the sultanate of Makassar on the western coast of South Sulawesi as its case.

There has, but for some recent exceptions, been a noticeable trend in the historiography of the Company's diplomacy to consider its diplomatic practice as based on dogmatic assumptions either of a legalist or cultural-Eurocentric nature. Implicit in both is that the diplomatic interaction between the Company and its Asian counterparts was a miscommunication as the meeting of the two represented a clash of cultures.

Against these propositions I argue that both the Director's concerns and the determining factor in policy decisions in Batavia were predominantly based on contextual considerations. By its very nature such an approach begged for precise and accurate information about local conditions and affairs.

Working top down I start by arguing that the respective Generale Instructies sent from the Heeren XVII from the Republic to the High Government in Batavia from 1609 to 1650 either implicitly or openly entailed a message to the High Government to gather information about be local customs and conditions and base its conduct of diplomacy on such knowledge. This approach is also reflected in the Directors' particular advice on Makassar.

As for the nature of mutual understanding in the diplomatic interaction between the Company and Makassar, the negotiations leading up to, and the formulations in the actual contract text of the first treaty between the two in 1637 bear witness to that the Company were playing the diplomatic game along compatible rules.

Turning to discussions on policy within the High Government itself, a disagreement arose between Governor-General Maetsuyker and Superintendent Arnold de Vlaming in 1655 on whether to take a hard- or a soft stand towards Makassar. That the issue was the subject of discussion in Batavia, and that the 
arguments from both sides were presented to the Heeren XVII, show that the Company's decision process on diplomacy was flexible and reactive rather than dogmatic.

As for dynamics and trends in the High Government's deliberations on Makassar, there is a decisive break after 1655 away from "soft diplomacy." After the conclusion of the 1655 treaty there developed a growing belief that a lasting contractual order with Makassar could not be established unless accompanied by a complete military victory. A close reading of the sections on policy towards Makassar in the Generale Missiven after 1655 reveals how Batavian decisions on diplomacy towards Makassar formed a "learning process" based on shifting interpretations of the situation and Makassarese intentions.

When analysing the texts of the treaty record between the Company and Makassar, one is struck by an impression that the Company's diplomatic approach is moving in a direction towards a more constructivist perception of "treaty" after 1655. This could be seen as an element in the learning process that characterised the High Government's diplomatic practice towards Makassar after the 1655 treaty.

The Bongaya Treaty of 1667 and its follow up contracts in 1668 formed parts of a treaty complex that included not only Makassar but the other states in South Sulawesi and the outer islands. Taken together these treaties made up a system whereby the Company attained a hegemonic position in South Sulawesi. When looking at the construction of Company as hegemon by contract it is striking that appeals to principles of international law plays a limited and very narrowly defined role. On the contrary the primary political functions of the contracts were formulated not with references to international law, but in detailed, concrete and specific phrases pointing to the relevant issues at hand.

In addition to dealing with the Directors' reflections on diplomacy and Batavian reports on and records of treaty making, as well as discussions within the Company on policy, and analyses of the implications of treaty formulations, I have also analysed reflections on policy by 'the man on the spot', Cornelis Speelman who in his memorie van overgave of 1669 pondered how to maintain the hegemonic position created by the Bongaya treaty complex. The text not only presents us with an implicit model of overseas diplomacy, but Speelman's explicit statements on his diplomatic exploits during his campaign 
in Makassar 166-68 also show how Company diplomacy was actually performed by one of the most able practitioners in the field.

Two factors stand out as general traits of Speelman's approach towards overseas diplomacy. Firstly, he advocates a case study approach. Decisions and choice of action must be based on as extensive empirical information as possible. The other trait is his emphasis on agency and personal diplomacy. Speelman's analysis is primarily focused on local power networks and the personal relations connecting them, and the tactical options that are left for Company influence and control. Personality traits of men who are in, or aspire to, power therefore form a prominent part in Speelman's text.

This personalised approach may be explained by the overall purpose of preempting the rise of foes and keeping the bonds of alliance with old and new allies in a political environment built on personal charisma and bonds. This emphasis on information gathering and the personalised approach seem to conform with the mode of diplomacy practiced by Company diplomacy at large.

Targeted gathering of information was consistently stressed in the General Instructions by the Gentlemen XVII, it was characteristic of the High Government's deliberations on policy in Batavia, and it marked the conduct of diplomacy on site. Awareness of and adaptation to local particularities thus formed the basis for the conduct of pragmatic diplomacy. The Company's practice of diplomacy towards Makassar conformed to this empirical and flexible rather than dogmatic Real Politik.

Consequently, this thesis refutes the proposition of a structural miscommunication in the Company's diplomatic dealings with Asian rulers. Obviously there occurred some misunderstandings, but these were not of an insurmountable nature, and generally speaking, there was sufficient understanding to make functional communication possible. Contributing to this was the fact that Makassar, in the first decades of contact and interaction with the Company, was ruled by very able and open-minded men, who showed particular interest in things European and a very strong will to innovate.

In conclusion, if in the Company's diplomatic mode, contextual considerations trumped a dogmatic approach to legal principles, this does not mean that it resulted in anarchy. What happened was that a pragmatic approach shaped the conceptualisation and the application of international law. On the one hand, this led to a constructivist perception of "treaty," whereby treaties were 
particularly designed for the specific context to which they were applied. On the other hand, appeals to general principles of international law were applied in instances where this was considered to best serve the Company's interests. In the final instance, both were based on pragmatic considerations. In this pragmatic approach was also an element of dynamism. 


\section{1}

\section{Presenting My Case}

\section{Section 1: Chapter Introduction}

In 2006, Martine van Ittersum could write "With one or two exceptions, the VOC's ideological and political dimensions have been neglected for a long time by both Dutch historians and specialists in the history of South East Asia." ${ }^{1}$ But for some exceptions, ${ }^{2}$ Ittersum's statement still holds true. This thesis is one of the exceptions. My topic is the nature of the diplomatic mode of the Company and I use the Company's diplomatic interaction with the sultanate of Makassar in the seventeenth century as my case.

Three points need initial clarifications. First, as for the use of the term "diplomacy" in the early modern period two explanatory remarks must be made. "Diplomacy" and "diplomatic action" will be used in the present context to cover any communication between Company officials and local men of power concerning specifics or general aspects of their mutual interaction. In short, the use of the term "diplomacy" is closer to "negotiations about practical matters in reciprocal affairs" than to "political state interaction" in the modern sense. ${ }^{3}$ Still, since the arrangement of reciprocal affairs must be considered "political" as it concerned distribution of power, the term "political interaction" too will be used in this broader meaning of "diplomacy".

Second, the present thesis is not a work of intellectual history, but rather a history of assumptions and perceptions characterising the Company's diplomatic practice. Third, the thesis is a case study, using the politico-diplomatic interaction between the port principality of Makassar on the west coast of Sulawesi and the Company in the period from their first treaty in 1637 until the treaties in 1667-68, which

1 Martine J. Van Ittersum, Profit and Principle: Hugo Grotius, Natural Rights Theories and the Rise of Dutch Power in the East Indies, 1595-1615 (Leiden: Brill, 2006), xliv.

2 See: Section 2, "A brief Chronology of VOC-Makassar interaction", below.

3 See for instance Leonard Blussé, Tussen Geveinsde Vrunden en Verklaarde Vijanden (Amsterdam: Koninklijke Nederlandse Akademie van Wetenschappen, 1999). 
effectively made the sultanate a dependency of the Company. The actual case, or "object of study," is neither the Company, nor the sultanate as such, nor their interaction as such, which has already been described. ${ }^{4}$ It is, rather, the interpretative implications of the Company's diplomatic practice in interaction with Makassar.

My main propositions are that at the outset the Company's diplomatic mode was neither Eurocentric, nor legally dogmatic, nor static, as has been claimed time and again in the historiography. To the contrary, I propose that the Company's seventeenth-century diplomatic mode, as demonstrated by the interaction with Makassar, was programmatically non-Eurocentric, pragmatically orientated, and dynamic.

\section{Contents and plan of the chapter}

After these general introductory notes, I shall proceed by giving a historical introduction to the kingdom of Goa-Makassar and a chronology of its diplomatic interaction with the Company circa 1637-68, and then present an overview of positions in the historiography of VOC diplomatic interaction. These positions and my own propositions will be further elaborated in chapter 2 .

\section{Section 2: A brief chronology of VOC-Makassar interaction, 1603-68}

\section{The twin kingdoms of Goa-Tello}

The term "Makassar" is originally an ethnic name, and could thus be applied to "where Makassarese" resided, but as a historical term it is applied to the twin kingdoms Goa and Tello, situated on the southwestern and southern tip of Sulawesi respectively. ${ }^{5}$ The two kingdoms are recorded as once being one kingdom, but split in two by a king dividing his kingdom between two of his sons, sometime in the fifteenth century, declaring that they should be twin kingdoms "with two lords, but one people."

4 I am thinking of F. W. Stapel, Het Bongaais Verdrag (Groningen: Wolters, 1922) and Leonard Andaya, The Heritage of Arung Palakka: A History of South Sulawesi (Celebes) in the Seventeenth Century (The Hague: Nijhoff, 1981), both to be commented on later.

5 Christian Pelras, The Bugis, Oxford, 1996, 116.

6 Ibid. 114. More accurately the formation of the double monarchy of Goa and Tello can be set to 1560, see John Villiers, "Makassar: The Rise and Fall of an East Indonesian Maritime Trading State, 
There was a working relationship between Tello and Goa up to the second half of the 17 th century where the ruler of Tello would be adviser or first minister to the king of Goa. In the Dutch records, this arrangement is reflected in that the ruler of Tello is designated as the "elder king" and the karaeng (noble) of Goa as "the younger king."

While some hold forth that the collaboration between Tello and Goa was a harmonious affair, ${ }^{8}$ others surmise that the unity between Goa and Tello, has been overdone, and suggest that it should be seen as a reaction to outside pressure, namely the Company's encirclement by its trading contacts in places such as Taiwan, Java, Solor, Timor, Buton, Moluccas, more than as a result of internal forces. ${ }^{9}$ In any case in the 1660 s political divisions had definitely developed between the then Sultan of Makassar, Hasanuddin and Raja Tello. ${ }^{10}$ But, be that as it may for now, what I want to state is that when I in the following use the term "Makassar", it is the twin kingdoms I am referring to unless otherwise indicated.

\section{Actors in the Makassarese political field}

The late sixteenth and seventeenth century rulers of Goa and Tello, of particular interest to us, are, beginning with Goa: Tumamenag ri Gaukanna, the sultan Alauddin (ruled 1593 to 15 June 1639), his son: Tumamenang ri Papambatuna, who ruled from 1639 to 5 November 1653, under the names of Sultan Malikusaid and Muhammad Said, and his son: Tumamenang ri Ballaq Pangkana, who ruled as Sultan Hasanuddin from 1653 to 17 June 1669 when he abdicated.

In the same period two important rulers of Tello who also functioned as advisers to the rulers of Goa, were: Karaeng Matoaya who ruled from 1593 to 1623 , and Karaeng Pattingalloang, who ruled from 1641 to September $151654{ }^{11}$

1512-1669", in: J. Kathirithamby-Wells \& John Villiers (eds.) The Southeast Asian Port and Polity, Rise and Demise, (Singapore: Singapore University Press, 1990), 147-148.

7 William Cummings, Making Blood White: Historical Transformations in Early Modern Makassar, University of Hawai'I Press, 2002, 112.

8 For instance John Villiers, Kathirithamby-Wells \& John Villiers (eds.) 1990, 149.

9 Arend de Roever, De jacht op sandelhout, Zutphen: Walburg Pers, 2002, 230.

10 Basset, D.K., "English Trade in Celebes, 1613-1677", Journal of the Malaysian Branch of the Royal Asiatic Society, 31/1 1958, 1-39, 35.

11 All based on: William Cummings, Reign List for the Rulers of Gowa and Talloq, in The Makassar annals, KITLV Press: Leiden, 2010, 351-52. 
Of the three Sultans of Goa mentioned, Sultan Alauddin and Hasanuddin concluded the treaties with the Company that I analyse. Of equal importance, if not even more, are the two rulers of Tello mentioned, because they helped form policy in their function as advisors to Goa. I shall return to them in my discussion of Makassarese dynamism in section 3 in chapter 2, but suffice it for now to point to the fact that both Matoaya and Pattingalloang are considered able politicians; in the words of Anthony Reid they represented an "extraordinary combination of intellectual eminence and political wisdom." ${ }^{12}$ Noorduyn for one, praises the sensible and pragmatic mode of Matoaya's policies. ${ }^{13}$

Added to this, and I shall return to this in more detail, is that both Matoaya and Pattingalloang displayed a preoccupation with all kinds of innovations, including European ones. Finally, it should be remarked that although Sultan Hasanuddin came to end the tradition of appointing the rulers of Tello as his advisor, ${ }^{14}$ two sons of Pattingalloang, namely Karaeng Karunrung and Karaeng Sumana came to play important roles during Hasanuddin's reign, as proponents of an aggressive and accommodating policy towards the Company respectively. ${ }^{15}$

\section{Internal tensions in South Sulawesi: The Bugis- Makassar dimension}

Political life in South Sulawesi centred on the split between four dominant ethnic groups, of which the Bugis and the Makassarese were the most important. ${ }^{16}$ These two groups were also politically dominant, occupying as they did the most fertile lands and having access to the most favourable harbour sites. ${ }^{17}$ As for historical kingdoms in South Sulawesi, the earliest dated from the tenth

12 Reid, Anthony, "A great seventeenth century Indonesian family: Matoaya and Pattingalloang of Makassar", Masyarakat Indonesia, 8/1, 1-28, 1981, 3.

13 Noorduyn, Jacobus, Een Achtiende-Eeuwse Kronik van Wadjo - Buginese Historiografie, Proefschrift, Universiteit te Leiden, 'S Gravenhage, 1955, 98, emphasising Matoaya's sensible politics, as for instance as seen in his non- offensive, conciliatory policy towards Bone during the Islam-wars.

14 Reid, 1981, 26.

15 Boxer, C. R., Francisco Vieira de Figueiredo: A Portuguese Merchant-Adventurer in South East Asia, 1624-1667, Verhandelingen, KITLV, 52, 'S-Gravenhage-Martinius Nijhoff, 1967, 30. For Karunrung in particular, see section the discussion of Speelman's considerations of him as friend and foe in chapter 9. Leonard Andaya, The Heritage of Arung Palakka, The Hague: Verhandelingen van het Instituut voor Taal-, Land- en Volkenkunde, 91, 1981, 9. Ibid.id. 9. 
century. ${ }^{18}$ By the middle of the sixteenth century, Makassar and the Bugis kingdom of Bone, situated to the east of Makassar stood out as the two most powerful in South Sulawesi. ${ }^{19}$ A series of wars between Bone and Makassar characterized the seventeenth century. ${ }^{20}$

For reasons that we need not go into here, in 1643 Goa, assisted by the Bugis states of Wajo and Soppeng (to the north-east and east in South Sulawesi respectively) attacked and defeated the Bugis state of Bone. ${ }^{21}$ The following year, after a period of uncertainty about the political standing of Bone, another battle was fought, and this time Bone's relation to Goa was reduced from one of "vassal" to "slave." ${ }^{22}$ Bone's defeat in 1644 marks the beginning of the career of the Bone Prince Arung Palakka, who was to take a leading role in a Bugis rebellion against Makassar in 1660, and after its defeat join with the Company and regain the independence of Bone in the joint Company-Bugis campaign of $1666-68$.

\section{The nature of politics}

Originally, political organisation was based on kinship groups and their offshoots, held together by origin myths of shared founding fathers. ${ }^{23}$ This kinship and sacred logic underlay the process when the original small kinship groups came to merge into larger confederacies and larger state units. ${ }^{24} \mathrm{An}$ integral part of state integration in the seventeenth century was the conversion of Goa to Islam in 1608 and the Islamic wars between 1608 and 1611 .

\section{The role of Islam}

One consequence of Goa's victory in the "Islamic wars" was the conversion to Islam of the Bugis states of Soppeng (1609), Wajo (1610), and Bone (1611). The Islamic wars should be fitted into the struggle for hegemony in South Sulawesi where Islam gave Goa extra prestige and power, and at the same time

\footnotetext{
18 Ibid.id. 17.

19 Ibid.id. 28.

20 Ibid.id. 9.

21 Ibid. 41.

22 Ibid. 42.

23 Ibid. $10 \mathrm{ff}$.

24 Ibid. 13.
} 
created new bonds of equality between the conquered and conqueror. ${ }^{25}$ It also gave Makassar status as an exemplary centre in the Archipelago, ${ }^{26}$ and proper Islamic piety became indivisible from political allegiance to $\mathrm{Goa}^{27}$

Extra potential power was also added to the converted states in that they could align with the Islamic powers in the archipelago as well as with the Muslim Ottoman and Mughal empires. For Makassar, there was also a commercial aspect to this, as Goa and the port of Makassar now became a link in the trade of spices from the Moluccas, which later was to become the main cause for friction and conflict with the Company.

With the conversion to Islam there was also a transformation in the institutions of the polity, as Islamic administrative and judicial institutions replaced traditional bodies. ${ }^{28}$ Also, there was an enhancement in the ideological power of the ruler as he was now officially regarded as the religious leader of society and polity. ${ }^{29}$ This acquired religious prestige and the position of the sultan as a defender of Islam in the Eastern Archipelago would also become an important issue in the conflict with the Company. Before we turn to the interaction with the VOC, we should take a brief look at Makassar's' expansion and role in the region outside South Sulawesi.

\section{The regional dimension}

Although some would say Makassar did not develop into an important sea power until the $1620 s,{ }^{30}$ already from the late fifteenth century Makassarese had diplomatic interactions with rulers of Mataram, Banjarmassin and Johor, as well as with rulers of Melaka and Timor. ${ }^{31}$

However already in 1580 a regional political settlement was reached between Makassar and Ternate where it was recognised that Saleyer should belong to the sphere of Makassar, but Buton to the sphere of Ternate. ${ }^{22}$ This did not however preclude a "constant Makassar struggle to establish its supremacy in

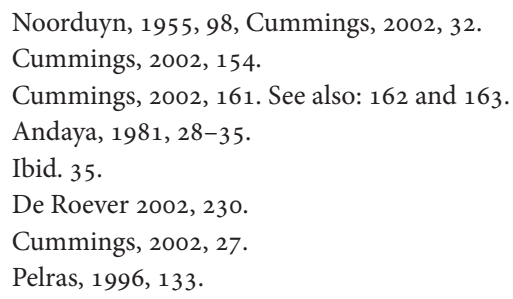


Buton", against the claims of Ternate, and later the Dutch. ${ }^{33}$ Anthony Reid claims that in the following period, under Matoaya's rulership of Tello and thus in his period as first minister of Goa, Makassar was the most important power between Java and Luzon, with its hegemony over most of Sulawesi, eastern Borneo, Lombok and Sumbawa. ${ }^{34}$

As it was, in the period of Matoaya, and after him up to the second half of the seventeenth century, Makassar led expeditions against Sumbawa in 1617, 1619, 1621 and 1632, against Lombok in 1624, against Buton in 1624, 1633, and 1639, and against Timor in 1640, ${ }^{35}$ while at the same time keeping close ties with Ternate and the Banda. ${ }^{36}$

At this junction in time Makassar's role as a regional power, and its role as a free haven for trade in spices, cloves and nutmegs from Ambon and Banda, which the Company regarded as a break of its monopoly rights, became enmeshed.

\section{The Ambonese wars}

Asian trade in East-Indonesia after 1625 increasingly became a Makassarese activity, ${ }^{37}$ including Makassarese sailings and trade with cloves in the western islands in the Ambonese archipelago, which meant breaches of Company contracts of monopoly. ${ }^{38}$ In reaction to Company efforts to enforce the monopoly the Kapitan Hitu, Kakiali and the Kimelaha of Hoamoal, Johu Luhu, sought and obtained support from Makassar against the Company, but lost out during the Hituese war of 1641-46. ${ }^{39}$ Because of its defeat to the Company in a decisive sea battle in 1642 hardly any cloves were for sale in the market in Makassar after that year, and the Company's realization of the VOC monopoly should thus be reckoned from 1642 rather than from 1656 (i.e., the subjugation of Hoamoal, see below) or 1667 (the subjugation of Makassar, see below).40

Anthony, Reid, “The Rise of Makassar", Review of Indonesian and Malaysian affairs, 17, 1983, 117-160, 139. Reid. $1981,8$.

where it came to have a lasting influence on the north coast, see Hans Hägerdal, Lords of the land, lords of the sea: conflict and adaptation in early colonial Timor, 1600-1800 (Leiden: KITLV Press, 2012), 98.

Pelras, 1996, 139.

Knaap, Gerrit, Kruidnagelen en Christenen: De VOC en de bevolking van Ambon 1656-1696, tweede herziende druk, Leiden: KITLV Uitgeverij, 2004, 24.

Knaap 2004, 27.

Knaap 2004, 28.

Knaap 2004, 28, referring to Basset, 1958. 
Still illicit trade continued to a degree, which led to the Company extracting so-called Hongi services from the local population in Ambon to patrol the sea lanes for smuggling. The Hongi services meant the bringing together of several smaller vessels, kora-koras, by several villages for this purpose. ${ }^{41}$ This led to local resistance and escalated into the so-called "Great Ambon" (or: Hoamoalese) war $1651-56 . .^{42}$ In this war the rebel leader Kimelaha Madjira received support from Makassar. ${ }^{43}$

On 29 July 1655, the rebel stronghold Asahudi was conquered by the Dutch. ${ }^{44}$ When the news of the peace between the Company and Makassar, concluded later in 1655, reached Ambon in the beginning of 1656, the Ambon war was over. ${ }^{45}$ As can be seen, the Makassar- Company rivalry formed an integral part of this struggle.

\section{Global dimension}

If there was a regional dimension to the Company's conflict with Makassar, there certainly was a global dimension as well. The confrontation between the Company and the Iberian powers of Portugal and Spain [which were united (1580-1640)] in the Moluccas can for instance be interpreted as part of the larger conflict over the issue of confession between the Protestant and Catholic states in Europe ${ }^{46}$ And Makassar was also part of this. One of the factors that made it essential for Van Diemen and successors to conquer the Spanish Moluccas in the 1640 s was the trade in Makassar of cloves from the Spanish forts in Tidore and Ternate. ${ }^{47}$ The maritime rivalry in Europe between England and the Republic was also, as we shall see, reflected in their rivalry to obtain goodwill in Makassar; on a larger scale one might, as Hägerdal for one indicates, follow Anthony Reid, and view the decline of Southeast Asian states such

41 "Kora-kora en kruitdamp - De Verenigde Oost-Indische Compagnie in oorlog en vrede in Ambon", in Knaap, Gerrit, and Teitler (eds.) De Verenigde Oost-Indische Compagnie tussen Oorlog en Diplomatie (Leiden: KITLV Uitgeverij, 2002), 261.

42 Knaap 2004, 29-30.

43 Knaap 2004, 33.

44 Knaap 2004, 34.

45 with the exception of Buru, where peace was not concluded not until 1658, Knaap, 2004, 34.

46 Knaap, Gerrit :«Kora-kora en kruitdamp - De Verenigde Oost-Indische Compagnie in oorlog en vrede in Ambon», in Knaap, Gerrit, and Teitler (eds.) 2002, 257-279, 258.

Basset, 1958, 18 . 
as Makassar in the second half of the seventeenth century as part of a global seventeenth century crises. ${ }^{48}$

Whatever the specifics of either the global or the regional dimension, both point to the fact that Makassar in the seventeenth century was a cosmopolitan harbour city which was part of both regional and global networks. This also meant that an increasing number of "outsiders" both visited and came to settle in the city too. I shall now take a closer look at these groups.

\section{The outsiders}

William Cummings points to the fact that already before the sixteenth century there had been centuries of Makassarese contact with Javanese and Malay traders. ${ }^{49}$ Still there is no doubt that the expansion whereby Makassar became a maritime power by the middle of the $16^{\text {th }}$ century increased its attraction to and its reliance on "outsiders." One such group of growing importance were the Malays.

The fall of Melaka in 1541 had worked as catalyst for a Malay diaspora to Makassar, ${ }^{50}$ and after the conversion to Islam the role of Malays increased both at the court of Makassarese rulers, and in the function as teachers and Mosque officials. ${ }^{51}$ Of other Asian visitors, albeit with a lesser internal influence, one could mention Chinese junks from 1619, as well as that there were agents from Jambi and Golconda in the city. ${ }^{52}$ As for Europeans, besides the VOC, mention must be made of the EIC which established a trading post in Makassar in 1613, the Danish India Company which did the same in 1618, and the French factory from 1622-1625. ${ }^{53}$ But above all the Portuguese played an important role, and particularly so after the fall of Melaka, when the numbers of stable residents reached up to 3,000 at the highest, and came to represent a "key figure in the life of the Sultanate", 54 An indication of the impact of Portuguese influence is that Portuguese was widely spoken at the court of Makassar. ${ }^{55}$

\footnotetext{
48 Hägerdal, 2001, 12. Referring to Anthony Reid, Southeast Asia in the Age of Commerce, 1450 - 1680, vol. 2, Expansion and crisis, 1993.

William Cummings, “The Melaka Malay diaspora in Makassar, c. 1500-1669”, Journal of the Malaysian Branch of the Royal Asiatic Society 66 (2): 107-122, 108.

50 Cummings, 1998, 108,

51 Cummings, 1998, 111.

52 Reid, 1981, 10.

53 Pelras, 1996, 141.

54 Basset, 1958, 18.

55 Villiers, in Kathirithamby-Wells \& John Villiers (ed.) 1990, 155.
} 
I shall return to the role of the Portuguese as agents of dynamism and innovation in Makassar in section 3, chapter 2 below, but will introduce the general argument here. Christian Pelras has argued that innovation was the hallmark of Bugis culture. ${ }^{56}$ This trait was only broken in the nineteenth century with the integration of South Sulawesi in industrial capitalism. As will be shown in more detail below, the same features of innovation and dynamism may be said to apply to Makassar in the late sixteenth and first half of the seventeenth century. This dynamism has (particularly by Reid) been ascribed to the international trade and maritime rivalry typical of those centuries. ${ }^{57}$ I shall, as mentioned above return to this phenomenon in more detail, when I will also point to criticisms of Reid for overdoing the effects of international trade. But it will suffice for now to say that there is a tradition of singling out a dynamic streak in Makassarese society at the time of its rivalry with the Company.

As for the particularity of the historical context of the MakassarCompany interaction in the seventeenth century, five major factors should be kept in mind regarding the background and standing of Makassar at the coming of the Company: firstly that Makassar already was an international entrepôt; secondly that it was connected to the spice trade in the Moluccas; thirdly that it was a cornerstone of Islam in the region; fourthly that the period of the first half of the seventeenth century was a dynamic one; and finally that there was latent tension within the realm connected to its conquest and subjugation of the Bugis.

\section{Chronological overview of the seventeenth VOC- Makassar interaction}

The first contact between Makassar and the Company took place in $1603,{ }^{58}$ when Company merchants stationed on Banda sent a request to the then Sultan Alauddin asking to be allowed into the realm. Permission was granted

\footnotetext{
56 Pelras, 1996, 150.

57 See vol. 2 of Southeast Asia in the age of commerce, 1450 - 1680, Expansion and crisis. And Reid, "Pluralism and Progress in seventeenth-century Makassar", in: Roger Tol, Kees van Dijk and Greg Acciaioli (eds.), Authority and Enterprise among the Peoples of South Sulawesi, Verhandelingen, KITLV 188, Leiden, KITLV PRESS, 2000, 55-73, 57.

58 Andaya has 1601 for the stationing of a Dutch factory on the invitation of Sultan Alauddin; Andaya $1981,45$.
} 
on condition that the Dutch would come for trading purposes only and not in large numbers. On those conditions, the Dutch were also allowed to establish a factory for their commerce. ${ }^{59}$ The sultan's emphasis on restricting the Company's activities was grounded in his awareness of the ongoing conflict between the Dutch and the Portuguese in Asian waters. He did not want to become entangled in this intra-European conflict. As time would show, there was no way to avoid this.

The Dutch factory was temporarily closed in 1607 , for internal Company reasons, but it reopened in 1609 . Harassment against Company servants by the Portuguese, to which the sultan turned a blind eye, did not make life any more pleasant for the personnel of the VOC factory, with the result that it was closed again in $1615 .{ }^{60}$ The Company's departure was accompanied by dramatic incidents that involved the killing of several Makassarese subjects who resisted being taken hostage by the Dutch. This was later avenged by the sultan, who ordered the killing of fifteen Company sailors after the hostages, among them a member of the sultan's family, had been returned. ${ }^{61}$ The incidents of 1615 demonstrates that even before the Company approached the sultan about a treaty in 1637 there had been serious tensions between the Company and Makassar that had led to outbreaks of violence on both sides.

\section{The monopoly on nutmeg and cloves as the central issue of conflict}

The core of the conflict between the Company and Makassar lay in the sultanate's infringement of the monopoly rights that the Company began to impose on trade in the Spice Islands. ${ }^{62}$ At the outset, the Banda Islands possessed a monopoly in production and sales of nutmegs and mace because it was the only place the nutmeg tree grew. Ships from all quarters flocked to its roadstead. But the coming of European buyers, first the Portuguese and the Spaniards, and in their wake the English and Dutch, resulted in armed rivalry.

\footnotetext{
59 F. W. Stapel, Geschiedenis van Nederlandsch Indië, vol. 3, Amsterdam: Joost van der Vondel, 1939, 192-93.

60 Ibid., 193.

61 Ibid. 193-94.

62 I lean on Leonard Blussé and Jaap de Moor, Nederlanders overzee: De eerste vijfig jaar 1600-1650 (Franeker: Wever, 1983), 110-41.
} 
The conquest of the islands in 1621 by Governor-General Jan Pieterszoon Coen solved the struggle in favour of the VOC. ${ }^{63}$ The result was that the Banda Islands were made a territorial possession of the Company, who deported the original population and repopulated the islands with slaves from Sulawesi among other places. The Company organised a system for the production of nutmeg and mace by the newly imported population. ${ }^{64}$ The Banda Islands thus became an essential part in the Company's monopoly regime.

I have already accounted for the Ambonese wars, so suffice it here only to repeat that the product was cloves, or kruidnagel. When the Dutch began to operate in the area in 1599 they were in competition with the English, whom they ultimately bested for control of the clove trade. A Company-controlled system of production similar to that used on Banda from the mid- 1620 s. $^{65}$

The point of relevance in our context is that the Company's monopoly rights in the Eastern Archipelago were to become the primary source of conflict between the Company and Makassar as the latter became a centre for the smuggling of "illicit" monopoly.

The fact that the Portuguese, English, and Danes could snap up smuggled cloves and nutmeg in Makassar was a steady provocation to the Company. ${ }^{67}$ Heaping insult upon injury, these European competitors of the Dutch also assisted the build-up of Makassar's military power. ${ }^{68} \mathrm{~A}$ final provocation was Makassarese expansionist aggression against the Company's declared ally of Buton. In response to a Makassarese siege of Buton in 1633, the Company sent ships to blockade the roadstead of Makassar in 1634, with the orders to destroy all local and Portuguese vessels. The Makassarese had anticipated the attack, however, and when the Company ships arrived, all Portuguese and local merchant vessels had already been evacuated.

Unable to move his ships closer to the coast, the commander of the Company's fleet had to watch a fleet of Makassarese war vessels bound for the Moluccas escape from the mouth of the river into open waters. In May of the

\footnotetext{
63 Ibid. 118-23.

64 Ibid. 123.

65 Ibid. 138. See also H. J. de Graaf, De geschiedenis van Ambon en de Zuid-Molukken (Franeker: Wever, 1977), 77-81.

66 "smuggling" and "illicit" in the eyes of the Company, of course.

67 Stapel, Geschiedenis van Nederlandsch Indië, 245-46.

68 Ibid. 246.
} 
same year, the Dutch learned that Buton had fallen to the Makassarese. The blockade of Makassar continued until August, when the fleet was ordered to return to Batavia. Another expedition sent later the same year met with even less success. The situation worsened when in 1635 the Company learned that the Butonese had started to act aggressively against the Dutch. A Company revenge expedition achieved little else but the exchange of prisoners. Such was the situation when in June 1637 Governor-General Anthonio van Diemen, having re- established peace and order in Ambon, left for Makassar to make an effort to end the conflict with the sultanate. ${ }^{69}$

\section{The 1637 negotiations and treaty}

The rebellion on Ambon had been intensifying since 1634 and in December 1636 Van Diemen, governor-general since January 1 of that year, set forth with an expedition to set matters straight. Having accomplished his mission, he left Ambon for Batavia in May the following year, but went via Makassar to see if difficulties could be overcome and peace concluded there..$^{70}$ Negotiations between Van Diemen and Sultan Alauddin took place between June 23 and 26, and resulted in a treaty of June $26 .{ }^{71}$ These negotiations and the June 26 treaty form the subject of chapter 4 . Suffice it for now to say that the agreement was a peace treaty, negotiated at a time when both parties were under pressure to obtain a positive result.

\section{From the 1637 peace to war, negotiations, and the 1655 treaty}

The smuggling of cloves from Ambon via Makassar continued after 1637, and when in 1652 one of the Ambonese rebel leaders, a kimelaha (district leader) named Madjira, went to Makassar to seek support there, the Company decided to send an embassy to Makassar to discourage the sultan from supporting him. ${ }^{72}$

\footnotetext{
69 Ibid. $245-46$.

70 Ibid. 244-45.

71 Corpus diplomaticum Neerlando-Indicum verzameling van politieke contracten en verdere verdragen door de Nederlanders in het Oosten gesloten, van privilegebrieven aan hen verleend, enz., edited by J. E. Heeres and F. W. Stapel, 6 vols. ('s-Gravenhage: Martinus Nijhoff, 1907-55), 1.303-306. (Hereafter Corpus Diplomaticum.)

72 Stapel, Geschiedenis van Nederlandsch Indië, 331.
} 
An expedition under the command of Jacob Hustard arrived at Makassar on February 1 only to find that Madjira had already left with thirty well-armed war vessels with the permission of the sultan, ${ }^{73}$ thus leaving Hustard's mission pointless.

After Hustard's return to Batavia, Arnold de Vlaming van Oudshoorn visited Makassar on his return trip from Ambon to Batavia, and tried to persuade the sultan to send envoys to Batavia for negotiations. His proposal was rejected, but the sultan was willing to give De Vlaming a diplomatic letter for the governor-general. The sultan's letter was of a general nature, just stating that he wanted to live in peace with the Company, but on condition that the Company allowed the people of Ambon and Ceram to live in peace and to practise their religion freely. As the selfstyled protector of those rights, he also gave notice that he had sent envoys to Ambon. Batavia considered the sultan's declaring himself protector and defender of peoples who were (by treaty) under the Company's protection, nothing less than a casus belli. At the meeting of the governor-general and Council on October 21, 1653, it was decided to declare war on Makassar. We do not need to go into the details of the campaign here, but will simply state that fighting started at the end of the same year, and the war went on until negotiations for peace took place late in 1655, which resulted in a new treaty dated December 28 of that year. ${ }^{74}$

As in 1637, the 1653-55 cycle of war, negotiation, and treaty was rooted in the issue over what the Company considered Makassarese infringement on its monopoly rights in the Moluccas. What distinguishes the 1655 peace from that of 1637 was that the former to a large extent came about under pressure from the Company directors in the Netherlands, and that it was accompanied by a robust internal discussion between Governor-General Maetsuyker and De Vlaming van Oudshoorn, who disagreed with the lenient tactics that were applied. This discussion forms the topic of chapter 5 .

\section{Tensions 1655-60, and another cycle of war, negotiations, and treaty}

Not long after the conclusion of the peace in 1655, it became clear that armed Makassarese vessels again had taken up sailings to the clove islands. In 
response, Governor-General Joan Maetsuyker sent Willem Basting as envoy to Makassar with the message that the sailings must stop or Makassar would once again find itself at war with the Company..$^{75}$ The Makassarese response to this was a cluster of counterclaims, one of which was that the Company give up its fortifications on Menado (in North Sulawesi) because, among other things, it was built on lands under the sultan's sovereignty. ${ }^{76}$ On receiving these claims, the Company once again declared war. The fleet under command of Van Dam and Johan Truytman arrived at the roadstead of Makassar on June 6, and engaged in battle immediately. ${ }^{77}$ Troops were landed on June 12, and Fort Panakkukang was seized. Given that loss, the sultan sent out feelers for negotiations, which resulted in a ceasefire. A Makassarese negotiation delegation was then sent to Batavia, and a treaty concluded there on August 19. ${ }^{78}$ The treaty was countersigned in Makassar on December $2^{79}$ the same year.

\section{Context and treaty making: The Bugis rebellion in 1660}

After the Company's conquest of Panakkukang in June 1660, 10,000 Bugis, among them nobles such as Arung Palakka, were ordered to dig a canal to cut the fort off from the mainland. They refused to do so and fled back to their homeland on August 7. ${ }^{80}$ Hasanuddin's preoccupation with laying siege to the Company's garrison in Panakkukang left the Bugis to reorganise and prepare themselves for new attacks by the Makassarese. ${ }^{81}$ During the fall, the Dutch were on the verge of being starved out, but were still hanging on, perhaps encouraged by news of the continuing rebellion of the Bugis. However, when a Makassarese offensive against the Bugis was finally launched, the rebellion was quelled in the beginning of October. ${ }^{82}$

What is of special relevance to us in this context is that the Bugis rebellion took place between the sending of Makassarese delegates to negotiate in

\footnotetext{
75 Ibid. 332 .

76 Ibid. 332-333.

77 Ibid. 333 .

78 Corpus Diplomaticum, 2.171-77.

79 Corpus Diplomaticum, 2.177-79.

80 Andaya, The Heritage of Arung Palakka, 49.

81 Ibid. 49.

82 Ibid. 50.
} 
Batavia in August and the countersigning of the treaty in Makassar in December. With the Bugis rebellion, an opportunity opened for the Company to renew the war with Makassar in alliance with the Bugis. But, by the start of the rebellion, the Company had already committed itself to negotiations, and by the time of the countersigning in Makassar in December, the Bugis rebellion had been quelled. Still the option of allying with the Bugis made its impact on Batavia's reflections on policy towards Makassar. The impact on policy positions by shifting constellations of contexts forms the topic of chapter 6.

\section{New tensions and decision for war, 1660-66}

Neither a complete stop the illicit traffic with the Moluccas nor the expulsion of the Portuguese as were agreed in the 1660 treaty were met in the years to follow. The traffic in the Moluccas continued, and even if some of the lower strata of the Portuguese left Makassar, the richer merchants stayed on. The latter filled an important military function, too, in the construction defence works. ${ }^{8}$ Sultan Hasanuddin confided to the Company's resident Jan Barra that a total expulsion of the Portuguese would lead to the destruction of his realm. A new Makassarese grievance against the Company was that Bugis rebels had taken refuge in Batavia, including the Bone leader Arung Palakka. To these grievances were added several lesser complaints that, together with a number of other incidents, led to the Company's decision to start another war on October $5,1666$.

It is important to note that before the final decision for war was taken, several attempts were made to negotiate a solution. For instance, on October 25, 1661 , the council decided to let the Makassarese who had been held as hostages as part of the 1660 peace settlement to return to Makassar. ${ }^{84}$ When on November 23, 1663, a decision was made to delegate Jacob Cau and Abraham Verspreet to go to Makassar to try to reach an accommodation, it was made with the instructions not to mention the continued presence of the Portuguese. The ensuing negotiations, taking place in the beginning of 1664, started off in a positive atmosphere, but were hampered by both the issue of the Bone refugees

83 Stapel, Geschiedenis van Nederlandsch Indië, 334.

84 Ibid. 334 . 
in Batavia and the accusation of the sultan that the Company had taken sides against him in Ternate and Buton.

What turned the atmosphere from tolerable disagreement into open conflict was the incident of the yacht De Leeuwin, which shipwrecked on the island of Don Duango on December 24, 1664, with 40 dead and 162 survivors, who were brought to Makassar. The Company's resident in Makassar, Verspreet, was prohibited from going to the ship to save the money case. ${ }^{85}$ Shortly after the incident, considerable amounts of Dutch money began to circulate in Makassar. A party of fifteen men sent to save the rest of the money were attacked and killed. When Verspreet himself later received threats, he saw no other option than to lock up the lodge and leave. ${ }^{86}$

Yet another attempt to reach a peaceful solution by negotiations was made when on November 20, 1665 when Receiver-General Joan van Wesenhagen was sent to Makassar. No agreement was reached however. Quite the contrary, Wesenhagen considered the mood in Makassar bellicose. He sensed a dedication to war, encouraged by the English there, and noticed signs of preparations for a campaign against the Company's ally, Ternate. Against the background of the threatening situation in the eastern quarters, on October 5 of the following year the High Government passed a resolution to prepare an expedition against Makassar. ${ }^{87}$

\section{A final cycle of war and treaty, 1667-68}

A fleet under the command of Cornelis Speelman sailed on November 24 and arrived at Makassar December 19. War started with the bombardment of Makassar city in late December, followed by a landing of troops further south. Speelman then sailed for Buton, which was besieged and conquered on January $3,1667 .{ }^{88}$ On January 31 , a treaty was concluded with the raja in which an annual stipend was accorded in exchange for the extinction of the clove trees on the island. This arrangement was to form the pattern for the other outer islands. $^{89}$

\footnotetext{
85 Ibid. 337 .

86 Ibid. 338 .

87 Ibid. 338 .

88 Ibid. 338-39.

89 See chapter 8.
} 
After the successful attack on Buton it was decided that Arung Palakka should go to Bone with his fellow Bugis to prepare a general revolt against Makassar, ${ }^{90}$ while Speelman, as instructed by the High Government, should go on to inspect the state of affairs in the eastern quarters. ${ }^{91}$

Speelman left Buton for the eastern quarters in February 1667 and returned to Makassar in June. In the Moluccas, Speelman brought about a peace between the sultans of Ternate and Tidore and linked them to the Company as their overlord and protector, ${ }^{92}$ which was of vital importance for the subsequent campaign.

\section{War on and in Makassar, June-November 1667}

In late June 1667 , Speelman returned to Makassar, and from July 1 hostilities in Makassar began and lasted until a ceasefire was reached at the end of October. The signing of a peace treaty, the Bongaya Treaty took place on November $18 .{ }^{93}$ I shall analyse the text of the treaty in detail in chapter 8 , so suffice it for now to say that in essence the treaty recognised the establishment of an autonomous Bugis state under Arung Palakka and effectively put the Company as overlord over Makassar, both politically and commercially. The Company's position was further secured by the sultan's cession of Fort Pandang, which was renamed Fort Rotterdam and became the Company's base in Makassar. ${ }^{94}$

\section{Securing the peace by war and still more treaties, 1667-69}

The news of the Bongaya treaty was received with celebrations in Batavia. A public mass of thanksgiving (dankpredicatie) followed by public celebrations, including a 200-gun salute, was held on March 14, 1668.95 Yet Speelman did not trust the Makassarese and doubted whether they would live up to the agreement. ${ }^{96}$ Several nobles, for instance, showed considerable opposition to the

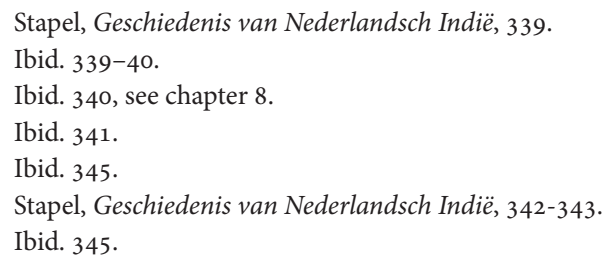


Dutch and the treaty, and neither the raja of Tello nor Karaeng Linques, another prominent noble of Makassar, had signed it.

Even when Speelman had the raja of Tello and Karaeng Linques sign the treaty on March 9 and 31, 1668, respectively, ${ }^{97}$ opposition continued, and open conflict broke out again April 12. Abortive peace talks took place in November 1668 and February 1669. On April 15, having received reinforcements from Batavia, the Company started its attack on Goa. The sultan's palace was finally conquered on June 24. The raja of Tello and Linques then signed a treaty confirming the one of March 1668, and on December 20, 1669, peace was finally confirmed with great pomp and circumstance in Fort Batavia. $9^{8}$

\section{Section conclusion}

The Bongaya Treaty and its aftermath marked a break in the nature of the relationship between the Company and Makassar. The interaction regime now in place was a multilateral, hierarchical one, comprising both Makassar and polities of the Eastern Archipelago, who were all bound together under the overlordship of the Company.

A characteristic trait of the 1666 campaign, and without doubt the one that won the day for the Company, was that it was allied to an internal Makassarese opposition, namely the Bugis coalition under the leadership of Arung Palakka. Reflecting this, the restructuring of power relations on South Sulawesi itself was woven into the Bongaya Treaty. This guaranteed Bugis independence from Makassar and recognised their homelands as an autonomous realm under Arung Palakka.

\section{Section 3: Approaches to VOC Diplomacy in the historiography: General overview}

\section{Section introduction}

The Dutch East India Company was given the power to sign treaties in the charter area. Counting from Heeres and Stapel's compilations, ${ }^{99}$ over five hundred treaties were concluded between the Company and Asian princes and

\footnotetext{
97 Ibid. 345 .

98 Ibid. 346-49.

99 Corpus Diplomaticum, vols. $1-3$.
} 
rulers during the Company's existence. That makes for an average of about twenty treaties a year, although the peak years were in the second half of the seventeenth century. It goes without saying that the larger part of this contractual corpus had been preceded by negotiations. We may thus conclude that both negotiating for and concluding treaties for political and commercial interaction was an integral part of the Company's undertaking in the charter area.

In this section, I shall be looking at approaches to the Company's diplomatic interaction with Asian rulers in the historiography from the nineteenth century to the present. The section will be divided into three subsections in which I first give an overview of some central positions in the interpretation of the nature of VOC diplomacy and the nature of the Company's interaction with local rulers in the charter area. I then place various positions and approaches along a historiographic timeline more generally, before I turn to a topical discussion focusing specifically on propositions about the role accorded to "international law" in the Company's overseas treaties.

\section{General types of approaches}

My typology of general approaches begins with the nineteenth and early twentieth centuries, ${ }^{100}$ which is characterised by a mixed narrative of commercial and political history, but with a bias towards the latter. C. H. Alexandrowicz's An Introduction to the History of the Law of Nations in the East Indies $\left(16^{\text {th }}, 17^{\text {th }}\right.$ and $18^{\text {th }}$ Centuries $)^{101}$ represents a second approach. He propagates a position I term "the system compatibility approach," which advocates a principled comparability and compatibility between Asian and Western systems of state interaction. G. J. Resink holds a modified but similar position. If I would subsume Resink in the system compatibility category, he still deserves further comments because of the function his views occupy in my argument by his insistence on compatibility between Makassar's and Western institutions of

\footnotetext{
100 To name some representative works in this tradition: J. K. J. de Jonge, M. L. van Deventer, et al. De Opkomst van het Nederlandsch gezag in Oost-Indie. Verzameling van onuitgegeven stukken uit het OudKoloniaal Archief. ('s-Gravenhage: M. Nijhoff, 1862-1909), both sources and introductory narratives; H. T. Colenbrander, Koloniale Geschiedenis, 3 vols. ('s-Gravenhage: Martinus Nijhoff, 1925-26); F. W. Stapel, in collaboration with E. C. Godée Molsbergen and H. Terpstra, Geschiedenis van Nerderlansch Indië, 5 vols. (Amsterdam: Joost van den Vondel, 1938-40).

101 C. H. Alexandrowicz, An Introduction to the History of the Law of Nations in the East Indies (16th, 17th and 18th Centuries (Oxford: Clarendon Press, 1967).
} 
diplomatic interaction. Resink also marks a special case in the historiography because of his mixed cultural background. He was born in Yogjakarta, served in the colonial administration, and did research on Indonesian legal system and diplomatic interaction after independence, when he also opted for Indonesian citizenship. ${ }^{102}$

A selection of his essays, published in 1968 by the Royal Tropical Institute of Amsterdam as Indonesia's History between the Myths points back to his article "Between the Myths: From Colonial to National Historiography," ${ }^{103}$ which appeared in 1952. Writing in the immediate postcolonial period, it is symptomatic that the myths he warns against are, on the one hand, an overinflated emphasis of the historical importance of Dutch colonial presence in Indonesia, while on the other hand he is also critical towards an Indonesian-centred chauvinistic approach. ${ }^{104}$ Of special importance in the context of this thesis is his article "The law of Nations in Early Macassar," ${ }^{105}$ the propositions of which serve well to problematize propositions about non-compatibility. Particularly Resink's discussion of Makassarese diplomatic practice highlights problems in assumptions that the Makassarese applied the same set of diplomatic standards towards foreigners that they did towards fellow South Sulawesian states. For now, however, I shall restrict myself to considering Resink as a special case under the compatibility category. I will return to his views on international law in Makassar in more detail in my elaboration of positions and propositions in chapter 2.

Returning to my list of types of approaches, the third is what I call the "cultural embeddedness approach," which is represented by Leonard Andaya's article "Treaty Conceptions and Misconceptions," ${ }^{106}$ and his book on Arung Palakka and seventeenth-century South Sulawesi. ${ }^{107} \mathrm{I}$ have also included a controversy between J. H. O. Paulusz and S. Arasaratnam over the Company's

\footnotetext{
102 Foreword, G. J. Resink, Indonesia's History between the Myths-Essays in Legal History and Historical Theory (The Hague: Van Hoeve, 1968), v-vi.

103 First printed in De Nieuwe Stem 7:6 (June 1952). My references are to the reprint in Resink, Indonesia's History between the Myths.

104 See the editors' "Foreword" in Resink, Indonesia's History between the Myths, vi- vii.

105 Originally written to be given as a lecture at the Faculty of Law in Makassar, first published in Dutch as "Volkenrecht in vroeger Makassar," Indonesië 6:5 (March 1953): 393-410. I use the English translation in, Indonesia's History between the Myths.

106 Leonard Andaya, "Treaty Conceptions and Misconceptions: A Case Study from South Sulawesi," Bijdragen tot de Taal-, Land-en Volkenkunde 134:2/3 (1978): 275-95.

107 Andaya, The Heritage of Arung Palakka, Verhandelingen KITLV 91, Martinus Nijhof, 1981.
} 
diplomatic interaction in Ceylon. ${ }^{108}$ Neither should be regarded as a defined type in his own right. Paulusz should be considered as part of the late nineteenthearly twentieth-century tradition, whereas Arasaratnam's argument lies closer to Andaya's. I have chosen to include their controversy because it casts light on the positions of Alexandrowicz and his critics as well as the prior historiography.

Jan A. Somers' Thesis: De VOC als volkenrechtelijke actor, ${ }^{109}$ and his Nederlandsch-Indië, Staatkundige ontwikkelingen binnen een koloniale relatie $e^{110}$ built upon it, are, as the titles suggest, both preoccupied with the legal relations between the Republic (and later the Kingdom) of the Netherlands-and Indonesia. Somers is included as a fourth type primarily because he occupies an ambivalent position between the nineteenth- and early twentieth-century writers and Alexandrowicz on the one side and his critics such as Leonard Andaya on the other side. I have called Somers' position a "legalist-pragmatic approach" because he seems to oscillate between assumptions that the Company's actions were determined by legal considerations even as he stresses the built-in need for the Company to act pragmatically given the circumstances of the overseas context. In Somers' perspective, the Company's diplomacy stands out as a strange combination of both legalist and pragmatic considerations leading to a mixed or ambiguous form of communication.

I have also included Martine Julia van Ittersum's work Profit and PrincipleHugo Grotius, Natural Rights Theories and the Rise of the Dutch Power in the East Indies (1595-1615). ${ }^{11}$ Van Ittersum earns her place in the selection because she offers an original interpretation of the nature of the Company's use of law by putting it in a broader historical and political context. Her main proposition is that the Company's legal arguments as articulated by Grotius should not be separated from considerations of power. In her view, the legal arguments served as little more than instruments of pure power. I have therefore termed her position "legal cynicism." Ittersum's "legal cynicism" transgresses the restricted legal

\footnotetext{
108 Respectively, J. H. O. Paulusz, “The 1638 Westerwolt Treaty in Ceylon: Charges of Dutch Deceit Disproved," Bijdragen tot de Taal-, Land-, en Volkenkunde, 136:2/3 (1980):321-52, and S. Arasaratnam, "J. H. O. Paulusz on the Westerwolt treaty in Ceylon: A Rejoinder," Bijdragen tot de Taal-, Land-, en Volkenkunde, 138:2/3 (1982): 191-205.

109 Proefscrift, Erasmus Universiteit Rotterdam, juni 2001.

110 Jan A. Somers, Nederlandsch-Indië, Staatkundige ontwikkelingen binnen een koloniale relatie (Zutphen: Walburg Pers, 2005).

111 See note 1.
} 
perspective generally dominant in the historiography on VOC diplomatic relations and practice, with the notable exception of Andaya and, possibly, Somers.

Having outlined these respective types of approaches to VOC diplomacy, I shall now turn to placing them in a broad chronological overview, in which I shall also include a section on the approach to and handling of the Company's diplomacy in Jurrien van Goor's writing on the Company's diplomacy. When I devote a separate section to him it is for two reasons mainly, first because he occupies a central position in the historiography, and secondly because I share his assumptions and propositions to an extent which makes it necessary to make clear what distinguishes my analysis from his.

\section{Section 4: Chronological overview of the historiography}

\section{Nineteenth- and early twentieth-century historiography}

Characteristic of the treatment of the Company's politico-diplomatic interaction and treaty making in the nineteenth- and early twentieth-century historiography is that the topic was treated chiefly in a descriptive matter, fitted into a chronological narrative. A recurring feature is telling the story of how treaties came into being and commenting on their essential terms. ${ }^{112}$ This tradition could be said to have been, and was later attacked for, operating from a Eurocentric point of view.

112 The selection and structuring principle of the source extracts in de Jonge, van Deventer, et al., De Opkomst van het Nederlandsch gezag in Oost-Indie is for instance both based on the Patriase Instructions, treaties and reports from Company servants on site to Patria, all centred on Company relations with specific places of interaction. In Colenbrander's three-volume work, only chapters 5-14 in volume 2 (1925) are dedicated to the Company period, where three of the chapters are concerned with local Indonesian history. Still the chapters that are dedicated to VOC interaction in Indonesia are mainly concentrated on the history of political events. Volume 3 of Stapel's Geschiedenis van Nederlandsch Indië of 1939 is organised by narrating a chain of events with an emphasis of political relations all structured by chronological time periods in respective places of operation, and thus conforms to the history of political events tradition. 


\section{The Van Leur break and the economic turn in the post- World War II historiography}

J. C. Van Leur ${ }^{113}$ represented a reaction to the "Eurocentric bias" in the traditional historiography, and promoted a shift towards a more Asia- centred viewpoint. After Van Leur, non-Eurocentric interpretations of CompanyAsian interaction were further developed and refined. In his De Nederlandse Koloniën, Jurrien van Goor, for instance, argued a "post-van Leur approach" that, in distinction from both the Eurocentric and Asiacentric approaches, focused on the interaction between the two. Van Goor's approach thus aimed at escaping both the pre-Van Leur Eurocentrism as well as avoiding the danger of underplaying the role of the VOC inherent in the Asiacentric approach. ${ }^{114} \mathrm{~A}$ perspective of interaction with a focus on the impact of Asian influences on the Dutch Republic was more recently applied in Gommans and Emmer's Rijk aan de rand van de Wereld. ${ }^{115}$

Another trend characteristic of the period after the Second World War was a shift of focus away from political interaction to economic history. So, while the changes in perspective starting with Van Leur came to relativize the role of the Company, with decolonisation the focus shifted away from narrative political-diplomatic history towards a more structural economic history. ${ }^{116}$

\section{Revisionist comparative perspectives and views on the nature of interaction}

Still, studies either directly or indirectly concerning the political interaction of the Company in the Asian arena came increasingly to be published after the 1970s, predominantly with a revisionist edge against Eurocentrism. Both European significance on a global scale and European modernity in global comparative perspectives were played down. Perhaps the most prominent exponent of this reorientation is Sanjay Subrahmanyam, who rejected both

\footnotetext{
113 J. C. van Leur, Indonesian Trade and Society: Essays in Asian Social and Economic History (The Hague: Van Hove, 1955), printed posthumously.

114 Jurrien van Goor, De Nederlandse koloniën: geschiedenis van de Nederlandse expansie, 1600-1975 (Den Haag: SDU Uitgeverij, 1993) 75.

115 Piet Emmer and Jos Gommans, Rijk aan de rand van de wereld: de geschiedenis van Nederland overzee 1600-180o (Amsterdam: Bakker, 2012), 15.

116 Van Ittersum, Profit and Principle, xlvi.
} 
the contrast between Asian stability and "European dynamism"117 as well the relative "modernity" of European actors in Asian waters. ${ }^{118}$ Anthony Reid's magnum opus on South East Asia in the Age of Commerce ${ }^{119}$ is a typical example of how the dynamism of local Asian societies was upgraded. Another, possibly less known, example is Claude Guillot's The Sultanate of Banten. ${ }^{120}$

Approximately ten years after Guillot, Johan Talens' presented a bleaker evaluation of the dynamism and developmental potential of Banten, ${ }^{121}$ but still his approach was non-Eurocentric by his choice of study-object. Also, it should be remarked that although apart from Andaya's contributions little had been written on the theoretical dimension of VOC diplomacy, an exception must be made for Talens. In an article of 1993, he accords considerable space to problematizing the commensurability and dynamics of conceptualisations of power and kingship by the Dutch and the Bantenese. ${ }^{122}$ This was an invitation for a discussion that has not been followed up.

Belonging to the general revisionism that followed Van Leur, but more radical in its perspective, was a reinterpretation, if not an outright rejection, of the idea of the West's modernising impact on Asian society. For instance, M. N. Pearson could write "nor can one see the early European settlements on the Indian coast as introducing positive European notions such as the rule of law that providing security for property and persons inevitably attracted merchants from the surrounding Asian-ruled, and so implicitly less lawful, areas. Quite the contrary." ${ }^{123}$

117 See for instance his "Aspects of State Formation in South India and Southeast Asia, 1500-1650," Indian Economic and Social History Review 23:4 (1986): 364-65, and Merchant Networks in the Early Modern World, edited by Sanjay Subrahmanyam (Aldershot: Variorum, 1996), xii.

118 There was thus no break between the era of the Portuguese $\left(16^{\text {th }}\right.$ century) and the $17^{\text {th }}$-century Company period. The Northwest European companies represented no break in mentality, Subrahmanyam - 93 p. 272.

119 Anthony Reid, Southeast Asia in the Age of Commerce, 1450-1680, vol. 1, The Lands Below the Winds (New Haven: Yale University Press, 1990) and Southeast Asia in the Age of Commerce, 1450-1680, vol. 2, Expansion and Crisis (New Haven: Yale University Press, 1993).

120 Claude Guillot, Hasan Muarif Ambary, and Jacques Dumarçay, The Sultanate of Banten (Jakarta: Gramedia, 1990).

121 Johan Talens, Een feodale samenleving in koloniaal vaarwater, Staatsvorming, koloniale expansie en economisch onderontwikkeling in Banten, West-Java (160o-1750) (Hilversum: Verloren, 1999).

122 J. Talens "Ritual Power; The installation of a king in Banten, West Java, in 1691", Bijdragen tot de de Taal- Land-en Volkenkunde 149, pp. 333-335.

123 M. N. Pearson, "Merchants and States," in The Political Economy of Merchant Empires: State Power and World Trade 1350-1750, edited by James D. Tracy, 41-116 (Cambridge: Cambridge University Press, 1991), 108. 
As for the nature of interaction and the direction of impact, even an inverse constellation to Eurocentric assumptions has been argued, as, for instance, by referring to the indigenisation of the European colonial enclaves in the eighteenth century: "With their endemic family feuds and institutional splits," Victor Lieberman writes, "the communities of $18^{\text {th }}$ century Batavia and Manila resembled indigenous courts more closely than a concern with formal structures might suggest." ${ }^{124}$

Still, when looking at the historiography of the European impact as a whole, Lieberman finds a pattern in which there is a movement away from a Eurocentric approach, passing through a revisionist Asiacentric reaction, and back to a renewed emphasis on the European impact. ${ }^{125}$ Lieberman subscribes to the relevance of the latter position with the reminder that "the collapse of the archipelagic states is inconceivable without the Dutch." ${ }^{126}$

It was not until 1999 that the first initiative to open up the study of VOC overseas diplomacy as a new field in its own right was taken. In his Tussen Geveinsde Vrunden en Verklaarde Vijanden, ${ }^{127}$ Leonard Blussé lamented that there was as yet no new, invigorating study of the diplomatic interaction between Western and Asian powers in the early modern period. To remedy the situation, he called for a systematic utilisation of the VOC archives to establish a "new diplomatic history of overseas diplomacy" on a par with Geoffrey Parker's "new military history." He pointed out that the VOC tuned its diplomatic practice throughout the Asian theatre according to existing local norms and rituals, and suggested that researchers should pay fresh attention to Heeres' source publications and give them a closer reading. ${ }^{128}$ Since Blussés original plea, a number of developments have occurred indicating that such a process was in the making. Among these were the conference held in conjunction with the quadricentennial jubilee of the VOC in 2002 and the resulting conference publication, De Verenigde Oost-Indische Compagnie tussen Oorlog en Diplomatie, ${ }^{129}$ as well contributions in the compilations published

\footnotetext{
124 Victor Lieberman, "Local Integration and Eurasian Analogies: Structuring Southeast Asian History," Modern Asian Studies 27:3 (July 1993), 568.

125 Ibid. 557.

126 Ibid. 554 .

127 Blussé, Tussen Geveinsde Vrunden, 1.

128 Ibid. 6.

129 Held in Den Helder and Leiden 2002, the contributions printed by Nederlandse Organisaties voor Wetenschappelilijk Onderzoek, 2002.
} 
in honour of Jurrien van Goor and Leonard Blussé in 2004 and 2011, respectively. ${ }^{130}$ Nonetheless, it seems fair to say that as of today the research programme that Blussé called for in 1999 has not fully blossomed. Van Ittersum's proclamation in 2006, seven years after Blussés original plea, that "the new history of international relations in monsoon Asia still needs to be written"131 still holds true today.

Regarding for instance general works on the Company or Dutch- Indonesian relations published from the second half of the 1990s, such as J. J. P. de Jong's De Waaier van het Fortuin: Van handelscompagnie tot koloniaal imperiu; De Nederlanders in Azië en de Indonesische Archipel 1595-1959, ${ }^{132}$ René Barendse's, The Arabian Seas $1640-1700,{ }^{133}$ or Els M. Jacobs, Merchant in Asia: The Trade of the Dutch East Company during the Eighteenth Century, ${ }^{134}$ but for Barendse ${ }^{135}$ none accorded any significant treatment to the Company diplomacy. ${ }^{136}$

In brief, Barendse's view on the nature of the Company's overseas diplomacy which he treats in chapter 4, "Diplomacy and the State", ${ }^{137}$ is that European overseas diplomacy in general and the Company's diplomacy in particular do not exclusively nor primarily represent a form of Eurocentric legalism, but rather a pragmatic configuration of the Asian societies formed to serve European purposes:

The problem is not just that Asian states were perceived through the distorted lenses of Roman or common law but that the policy of the Company was justified by a peculiar interpretation of Asian societies ${ }^{138}$.

The pragmatic configuration Barendse has in mind more particularly, is a lack of "constitutional safeguards to liberty", in other words, "despotism." ${ }^{139}$ So, on

\footnotetext{
130 Namely Elsbeth Locher-Scholten and Peter Rietbergen, eds., Hof en Handel: Aziatische Vorsten en de VOC 1620-1720 (Leiden: KITLV, 2004), and J. Thomas Lindblad and Alicia Schrikker, eds., Het Verre Gezicht Politieke en culturele relaties tussen Nederland en Azië, Afrika en Amerika (Franeker: Van Wijnen, 2011).

131 Van Ittersum, Profit and Principle, li.

132 Sdu Uigervers, Den Haag, 1998.

133 Leiden: CNWS, 1998.

134 Leiden: CNWS Publications, 2006.

135 Chapter 4: "Diplomacy and the State"

136 "diplomacy" is for instance neither in de Jong's nor in Jacob's index.

137 Barendse 1999, 100-126.

138 Barendse 1999, 104.

139 Ibid. 105, 108.
} 
the one hand Barendse supports the legalist Eurocentric assumption with modifications by giving it a constructivist twist by referring to how propositions about "Asiatic despotism" served to legitimate actual European overseas practice. The latter proposition in one sense foreshadows implications of cynicism later brought forward by Van Ittersum. ${ }^{140}$

So where does that leave us as far as the historical writing on the Company's overseas diplomacy after the middle of the twentieth century is concerned? First, there was comparably little of it until after the 1970s, as the scene before then was dominated by economic history. The little there was on political interaction history was to a large degree dominated by a variety of revisionist trends. But, it was not until the end of the millennium that pleas for a "new overseas diplomatic history" by their own right began to make their mark.

\section{Entering a new millennium: The coming of a "new diplomatic history"?}

The 199os saw the publication of a number of case studies such as, Reinout Vos' study on VOC diplomatic interaction on the Malay Peninsula, ${ }^{141}$ and Luc Nagtegaal's study of the intertwining of the Company's diplomatic and commercial interaction on the north coast of Java. ${ }^{142}$ Indicative of a renewed interest in the cultural dimension of the Company is the work of Femme Gaastra, usually associated with studies of the commercial aspect of the Company, who at the end of the 199os published on sociocultural aspects. ${ }^{143}$

While the plea for a new diplomatic history of the European overseas expansion and global interaction originally came from Leonard Blussé, one person who has exhibited a consistent interest in the cultural dimension of the

\footnotetext{
140 See below.

141 Reinout Vos, Gentle Janus, Merchant Prince, The VOC and the Tightrope of Diplomacy in the Malay World (Leiden: KITLV Press, 1993).

142 Lucas Wilhelmus Nagtegaal, Riding the Dutch Tiger-The Dutch East Indies Company and the Northeast Coast of Java, 1680-1743 (Leiden: KITLV, 1996).

143 Femme S. Gaastra, "Competition or collaboration? Relations between the Duct East India Company and Indian Merchants around 1680," in Merchant Companies and Trade: Europe and Asia in the Early Modern Era, edited by Sushil Chaudhuri and Michel Morineau, 189-201 (Cambridge: Cambridge University Press, 1999).
} 
Company and its diplomatic dealings with local rulers deserves to be brought forward, namely Jurrien van Goor.

\section{Jurrien van Goor's positions on Company diplomacy}

An increased interest in and emphasis on the cultural dimension characterised the historiography of the Company from the late seventies. Typical topics were Asiatic modes of thinking about power and religion, interpersonal relations, ceremony and ritual considered both as form and substance, and miscellaneous aspects of the Company's political and diplomatic practice in Asia. ${ }^{144}$

These topics could well be described as typical of the historical writings of Jurrien Van Goor too. Born in 1939 and teaching at Groningen and Utrecht Universities before he retired in 2004, Van Goor is a prominent figure in the writing on Dutch colonial history. If we look at a selection of titles from his bibliography: Jan Kompenie as Schoolmaster: Dutch Education in Ceylon 1690-1795, ${ }^{145}$ Kooplieden, predikanten en bestuurders oversee: Beeldvorming en plaatsbepaling in een andere wereld, ${ }^{146}$ Trading companies in Asia: 1600$1830,{ }^{147}$ his general history of the Dutch expansion and colonies both in Asia and the Americas: De Nederlandse Koloniën; Geschiedenis van de Nederlandse expansie $1600-1975,{ }^{148}$ the bundle: Indische Avonturen: Opmerkelijke ontmoetingen met een andere wereld, ${ }^{149}$ and Prelude to Colonialism: The Dutch in Asia,${ }^{150}$ where he compares the early modern and modern Dutch expansion and colonialism in Asia, and his 2015 biography of Jan Pieterszoon Coen, ${ }^{151}$

\footnotetext{
144 Peter Rietbergen and Elsbeth Locher-Scholten, "Een dubbel perspectief; Aziatiasche hoven en de VOC, ca 1620 - ca 1720", in Rietbergen and Locher-Scholten (ed.) Hof en Handel, Aziatische vorsten en de VOC 1620-1720, (Leiden: KITLV Uitgeverij, 2004), 5.

145 1978: Jurrien van Goor, Jan Kompenie as Schoolmaster: Dutch Education in Ceylon 1690-1795, (Groningen: Wolters Noordhoff, 1978).

146 Jurrien van Goor, Kooplieden, predikanten en bestuurders oversee: Beeldvorming en plaatsbepaling in een andere wereld, (Utrecht: HES Uitgevers, Utrecht, 1982).

147 Jurrien van Goor, Trading companies in Asia: 1600-1830 (Utrecht : HES Uitgevers, 1986).

148 Jurrien van Goor, De Nederlandse Koloniën; Geschiedenis van de Nederlandse expansie 1600-1975, (Bielthoven: Sdu Uitgevers, 1994, 1997).

149 Jurrien van Goor, Indische Avonturen: Opmerkelijke ontmoetingen met een andere wereld, Indische Avonturen: Opmerkelijke ontmoetingen met een andere wereld, (den Haag: Sdu Uitgevers, 2000).

150 Jurrien van Goor, Prelude to Colonialism: The Dutch in Asia (Hilversum: Uitgeverij Verlooren, 2004).

151 Van Goor, 1982, $12 \mathrm{f}$.
} 
his preoccupation with the cultural and politico-diplomatic aspects of the Company becomes clear.

\section{Positions and plan of the exposition}

Van Goor raises the same kind of questions and propositions that I do in my theses, namely that the Company occupied a position in the various local diplomatic system, that its preferred mode of operation was by accommodation, unless forced by circumstances or particular interests to act otherwise, and that both the local parties and the Company managed to come up with a functional understanding of the other party's concerns and intentions. Here I agree fundamentally with Van Goor.

Having pointed to these fundamental agreements, there are also some points where I do deviate from Van Goor's propositions and assumptions. My plan of exhibition in this section is that I shall first elaborate and define Van Goor's positions, and then will go on to point out what I say that Van Goor does not say, and where I disagree with him.

\section{Van Goor's positions on the nature of the Company's diplomacy}

To clarify Van Goor's positions on the nature of the Company's diplomacy one may start with his more general positions on the Company historiography. While on the one hand he expresses support for Van Leur's Asia-centric turn, ${ }^{152}$ he on the other hand also criticises Van Leur for not going into the problem of how the Company acquired its prominent commercial and political position in the archipelago. ${ }^{153}$ His criticism of Van Leur on this point reflects his focus on the Company's politics and diplomacy in his own research. Van Goor's basic assumption is namely that close links between trade and politics were built into the Company's dual nature as merchant and king from the start. ${ }^{154}$ The more specific questions that arise from this assumption he lists as, first: If the Dutch were assigned a position in the local diplomatic system, what was exactly their position? Second: Did the local diplomatic systems in the Charter

\footnotetext{
152 Van Goor, 1982, $12 \mathrm{f}$.

153 Van Goor, (1993) 1997, 75.

154 Van Goor, 2004, 27, Van Goor 2015, 522.
} 
area and the Company's position in them differ from home? Third: If the local systems did differ from the European one, did the Dutch adapt, or was the Dutch behavior a product of mixed traditions? The third question also entails a fourth one, namely whether both parties understood or misunderstand each other; ${ }^{155}$ in other words van Goor implicitly also raises the problem of commensurability.

\section{Van Goor's position on the Company's position in the overseas diplomatic systems}

It is Van Goor's contention that the Company in the archipelago represented a new actor playing in an already established game. ${ }^{156}$ It thus came to form an integral part of the local political system. ${ }^{157}$ In this game the Company could be used as a pawn in the local power struggle. ${ }^{158}$ But, on the other side, the Company was also perceived as an attractive ally by local princes, ${ }^{159}$ a fact that Van Goor among other factors attributes to its reliability as a political partner. ${ }^{160}$ His general proposition on the Company's position and interaction with local rulers is then that there was cooperation and that an aspect of this cooperation was that the Company and local rulers could share ideas of mutual profit. ${ }^{161}$

\section{Accommodation as preferred interaction mode and its implications}

Variations in the mode of the Company's interaction varied from withdrawal to accommodation to resorting to violence. Complete partnership was rarely present (zelden anwezig). ${ }^{162}$ The specific modes of accommodation depended on the respective context or forms of imbalance or asymmetric relations of

\footnotetext{
155 Van Goor, 2004, 28.

156 Van Goor, (1993) 1997, 75.

157 Van Goor (ed.), 1986, "Introduction", 16.

158 Van Goor, 2004, 34.

159 Van Goor, "Seapower, Trade and Stateformation: Pontianak and the Dutch", in Jurrien van Goor (ed), Trading Companies in Asia: 160o-1830, 83f. (Utrecht: HES Uitgevers, 1986).

160 Van Goor, 2015, 522.

161 Van Goor, (ed.) 1986, 104.

162 Van Goor, (1993) 1997, 84, 91.
} 
power in which they were applied. ${ }^{163}$ In accommodation lay then an in-built drive to understand what to accommodate to. In other words: An incentive to learn about the local ways to be able to handle the various challenges that the Company faced, be they commercial transactions, or social and political relations, was an intrinsic element in the accommodating approach. ${ }^{164}$ Not unexpectedly, this meant that the Company's diplomatic and local diplomatic practice came to take on similar traits.

\section{Comparative aspects and the issue of commensurability}

Regarding the comparative dimension in the diplomatic interaction between the Company and local rulers in Southeast Asia, Van Goor finds resemblances: "The regional states shared a number of characteristics of the Kompeni state,"165 and holds that there was a striking resemblance in the diplomatic mode of operation too: "In both diplomatic and ceremonial respects, Batavia behaved like any other kingdom in the region". ${ }^{166}$

What then of the specificity of the Company's diplomacy? On commentating on Coen's "diplomatic mode", Van Goor characterises it as based on a combination of legal arguments, power politics and sensitivity to local conditions. ${ }^{167}$ As for the nature of the "International law" in question, he describes it elsewhere as being based on natural right theories, ${ }^{168}$ meaning it was of a crude, general practical nature. This position is well illustrated by Van Goor's depiction of the Company's mode towards Siam. Here the Company's success was based on "political knowhow and accommodation to the context, without involving itself too much in internal developments". ${ }^{169}$ There was not an absolute divide between the Company and the local diplomatic actors. Pragmatism ruled the day. As stated above, by implication this pragmatism rests on an

\footnotetext{
163 Van Goor, (1993) 1997, 91.

164 Van Goor, (1993) 1997, 130.

165 Van Goor, (ed.) 1986, 85.

166 Van Goor, 2004, 25.

167 een combinatie van juridische argumenten, machtspolitiek en gevoel voor de lokal omstandigheden, Van Goor, 2015, 175 (in conjunction with treatment on how Coen envisaged the Company should acquire monopoly).

168 Van Goor, 2015, 46of, and referring to Van Goor 1982, 66-76, and Van Goor 1986, 23-33.

169 Door politieke handigheid en aanpassing aan de omgeving, zonder zich al te veel in te laten met de interne ontwikkelingen Van Goor, 1982, 51.
} 
assumption of commensurability by Van Goor in that pragmatic accommodation had to be based on an ability by the Company to understand what they had to accommodate to.

\section{Comparisons at the macro-cultural level}

Returning to the comparative aspect per se, if we move one step higher up the ladder to a more general level of comparisons, we find that Van Goor does not comply with the view that there was an absolute divide between the Company and local perceptions when it came to cultural models at the macro-cultural level. More specifically he rejects the assumption of an absolute divide between a European rational- and a mythological Asian world view. Quite contrarily he finds parallels as well as contrasts when it comes to integrating mythological aspects in Southeast Asia and the Republic, and thus recognises a role for "magical" interpretations in both places. ${ }^{170}$

Having pointed out this relativism in Van Goor's views, it must also be said that he still subscribes to the view that there was a difference between the Company's institutional and the local personalised perception of power and interstate relations. ${ }^{171}$ European and Southeast Asian conceptualisations of state-interaction are described as based on international (horizontal) law and (vertical) conceptions of hierarchies of rank respectively. ${ }^{172}$ But Van Goor also describes the European diplomatic system on a par with his relativistic view of the macro-cultural field in a way to make the contrast to the Southeast Asian one as of a relative and not absolute kind. For instance, he makes a point that one of the defining qualities of the European system, reciprocity, did not lead to equality. ${ }^{173}$ Thus a kind of hierarchical order is a defining feature of both European and Asian interstate systems. He also points to similar comparable features regarding the exchange of envoys in Europe and Asia in the seventeenth century. ${ }^{174}$ Furthermore he states that status as motive for diplomatic

\footnotetext{
170 Van Goor, 2015, 344.

171 Van Goor, (1993) 1997, 134.

172 Van Goor, 2015, 46of, referring to Van Goor 1982, 66-76 and Van Goor (ed.) 1986 23-33.

173 Van Goor, 2004, 28.

174 Van Goor, 2004, 35.
} 
exchange was not confined to Asia. ${ }^{175}$ Another point of similarity put forward is the function and meaning in gift-giving. ${ }^{176}$

In a similar mode, although on a more general level, Van Goor points out that the political culture in the Indonesian archipelago often is characterized as a culture of shame (een schaamtecultuur), ${ }^{177}$ by which is meant a mentality dominated by concerns of prestige and status. But, says Van Goor, one must consider that concerns of and sensitiveness to honor and respect for rank and status were strong in seventeenth century Europe too, although it was even more so in Asia. ${ }^{178}$ Batavia for one was ridden by concerns of status and pride, ${ }^{179}$ and Van Goor regards concerns of prestige and status generally as central in the Company's diplomatic practice. ${ }^{180}$

In our context, the significance of Van Goor's view that there was a degree of commensurability between the Company's and local modes of diplomacy lies in the implication that there was possibility for meaningful communication.

As for Van Goor's view on the particularity of the Company's mode of diplomacy in a European comparative context, and the form of prestige and status constituent of it, he makes and important qualification. He on the one hand holds that the VOC constituted an Ancien Regime state. ${ }^{181}$ But at the same time he underlines that its mode of diplomacy was characterized by a flexibility stemming from its merchant background which was opposed to the inflexible honour-mode of diplomats from the nobility. ${ }^{182}$

Another word for "flexibility", is "pragmatism", and on this as a general characterisation and the points of view outlined above I am in full agreement with Van Goor. This leaves us with the question as to on which issues we do not agree and the nature of our differences, or put in other words: What do I do in my thesis which Van Goor does not do?

\footnotetext{
175 Van Goor, 2004, 40.

176 Van Goor, 2004, 43.

177 Van Goor 2015, 132.

178 Van Goor 2015. 132.

179 Van Goor, 2015, 468.

180 Van Goor, 2004, 24.

181 Van Goor, (ed.) 1986, 85.

182 Van Goor, 2004, 33.
} 


\section{The singularity of my analysis compared to Van Goor's positions}

If there is one topic, which admittedly is implicit in Van Goor's discussions, but which I make much more explicit, it is the problem of whether and to which degree the Company did understand the diplomatic thinking and practices of their local partners and antagonists. Analysing this problem necessitates a consistent use of textual analysis of the actual wording in the Company's diplomatic exchanges that separates my analysis from Van Goor's. My proposition of commensurability between the Company and its diplomatic partners is thus both more consistently pursued and more explicitly advocated by textual analysis than is the case in Van Goor's works.

Another difference is that whereas Van Goor often treats the Company's diplomacy in conjunction with other overarching problems, my primary focus is and remains the nature of the Company's thinking about and practice of diplomacy. My "topical case" is Company diplomacy. Viewing it from one historical case, Makassar, made it possible for me to analyse the Company's diplomatic practice from different angles and levels, ranging from the advice from Patria to the advice from Company servants in Makassar to Batavia and to do so, when needed, at the microlevel. Two additional aspects of choosing Makassar as my case stand out.

Firstly, in the interaction between the Company and Makassar, we are faced with a case of shift of diplomatic approach in that an initial flexible-pragmatic approach of peaceful negotiations was abandoned for a strategy to intervene militarily directly in the internal politics of Makassar. The latter option arose by the possibility to ally with a local actor, also in conflict with Makassar. In Batavia, there was debate over strategy in conjunction with this possibility which made it possible for me to get a peep into the Company's internal debate on policy.

Case Makassar: then let me analyse and compare the Company's diplomacy in three distinct approaches: Wooing by negotiations with peaceful intent, negotiating and warring with the intent of intervention to restructure the political order, and tying bonds with a local ally. These variations in contexts make Makassar a perfect match for an in-depth analysis of a set of complementary aspects of the nature and dynamics of the Company's diplomacy. 
Second, the already existing historiography on Makassar made it possible for me to go in depth into and formulate counterpropositions to theoretical assumptions of a structural kind of analysis which I hold to contain structural weaknesses. In my explicit discussion on these theoretical problems I do something which is not openly set out in Van Goor's works.

\section{Bringing it up to date, 2010-14}

Bringing this overview up to date, but by no means claiming to present an exhaustive list, another person who has made a mark in the recent historiography on cultural contact and diplomacy is Markus Vink. ${ }^{187}$ Mention should also be made of Blussés article, "Peeking into Empires: Dutch Embassies to the Courts of China and Japan," ${ }^{188}$ the essays gathered in The Dutch Trading Companies as Knowledge Networks, ${ }^{189}$ Adam Clulow's The Company and the Shogun: The Dutch Encounter with Tokugawa Japan, ${ }^{190}$ and Matthias van Rossum's, Werkers van de Wereld; Globalisering, arbeid en interculturele ontmotingen tussen Aziatische en Europese zeelieden in dienst van de VOC, 1600-1800. ${ }^{191}$ As all these contributions were published between 2010 and 2014 , they may represent an upsurge in the study of the cultural and politico- diplomatic dimension of the Company.

183 Jurrien van Goor, Jan Kompenie as Schoolmaster: Dutch Education in Ceylon 1690-1795 (Groningen: Wolters Noordhoff, 1978).

184 Jurrien van Goor, Kooplieden, predikanten en bestuurders overzee: beeldvorming en plaatsbepaling in een andere wereld (Utrecht: HES, 1982).

185 Jurrien Van Goor, Prelude to Colonialism: The Dutch in Asia (Hilversum: Uitgeverij Verloren, 2004).

186 See n. 92, above.

187 See, for instance, Markus P. M. Vink, "Images and Ideologies of Dutch-South Asian Contact: CrossCultural Encounters between the Nayak State of Madurai and the Dutch East India Company in the Seventeenth Century," Itinerario 21:2 (1997): 82-123, and idem, Mission to Madurai: Dutch Embassies to the Nayaka Court of Madurai in the Seventeenth Century (New Delhi: Manohar, 2012); and numerous reviews.

188 Leonard Blussé, "Peeking into Empires: Dutch Embassies to the Courts of China and Japan”, Itinerario 37:3 (2013), pp 13-29.

189 Siegfried Huigen, Jan L. de Jong, and Elmer Kolfin, eds., The Dutch Trading Companies as Knowledge Networks (Leiden: Brill, 2010).

190 Adam Clulow, The Company and the Shogun: The Dutch Encounter with Tokugawa Japan (New York: Columbia University Press, 2014).

191 Matthias van Rossum, Werkers van de Wereld; Globalisering, arbeid en interculturele ontmotingen tussen Aziatische en Europese zeelieden in dienst van de VOC, 1600-180o (Hilversum: Verloren, 2014). 


\section{Van Meersbergen}

Finally, in the finishing stages of my own work, I was made aware of Guido van Meersbergen's PhD thesis Ethnography and Encounter: Dutch and English Approaches to Cross-Cultural Contact in Seventeenth-Century South Asia. ${ }^{192}$

Although Van Meersbergen's work and mine clearly overlap as far as topic and issue are concerned, there are also some differences. Van Meersbergen presents his analysis of the VOC and EIC documentation as focused on "what it reveals about perceptions of Others, categories of human difference, and approaches to cross-cultural interaction." ${ }^{193}$ Thus Van Meersbergen may be more focused on ethnographic assumptions "shaping worldviews" in the general, while I focus more specifically on assumptions in the Company's diplomatic interaction. In brief, I may tend to put more emphasis on the context of diplomatic interaction whereas Van Meersbergen puts emphasis on cultural tradition.

I shall briefly state some points that follow from this difference. First, I hold that the Company was not acting on an overarching theory or general assumptions of cross-cultural interaction; it primarily relied on casuistic reflections and advice. The whole issue of diplomacy was approached practically and pragmatically. This is to say-and this may be the main difference between Van Meersbergen's thesis and my own - that I am not convinced that VOC personnel brought a set of cultural meta-conceptualisations with them overseas that were then used uncritically as a grid through which all their observations and reflections were processed. The Company's servants were perfectly aware that they were in foreign lands and adopted ways of reflection to adapt to that fact.

Second, as for modes of adaptation, Company servants could draw on the Portuguese cross-cultural experience, from which they could pick and choose, to model their behaviour as outsiders. Third, and this is the view that I shall particularly be pursuing in the following, the Company's overseas experience was by itself a learning process by which the Company came up with different responses and adjusted them to the overseas challenges.

\footnotetext{
192 Guido van Meersbergen, Ethnography and Encounter: Dutch and English Approaches to Cross-Cultural Contact in Seventeenth-Century South Asia (PhD diss., University College London, 2014).

193 Ibid. "Abstract," 5.
} 
The present thesis is meant as a contribution to a "new history" of overseas early modern diplomacy, by presenting a case study in the Company's seventeenth-century overseas diplomatic practice. In particular, I intend to clarify the restricted role of international law, the specific meaning and function of the overseas diplomatic treaty, and the rules guiding negotiations for regimes of interaction in the Company's diplomacy.

My reasons for undertaking this project are that I think that the nature and dynamics of the Company's diplomatic practice have been misunderstood or distorted. Too much emphasis has been placed on law, too little on the practical dimensions of diplomacy and negotiations. Before elaborating on my own positions on these points, ${ }^{194}$ I first need to go more into detail regarding the historiography on the above issues.

\section{Section 5: Positions on and propositions about law and treaty}

Nobody denies that exchange of envoys and letters as well as conclusion of agreements between rulers took place in both early modern Southeast Asia and Europe. Opinion is split, however, as to whether these diplomatic activities meant the same in Asia as in Europe and also whether transcultural diplomacy in early modern Asia represented a clash of political cultures or an interaction between compatible systems.

As these issues go directly to the heart of my thesis, I shall dedicate the rest of this chapter to clarifying a variety of positions and propositions on the understanding and meaning of "international law" and "treaty" and assumptions about compatibility and incompatibility among Asian and European systems of state interaction. I shall pick my examples from the selection of works already mentioned, starting with the "classical" historiography of the nineteenth and early twentieth centuries, then turn to C. H. Alexandrowicz's propositions. ${ }^{195}$ I then go on to clarify Leonard Andaya's refutations of positions in the nineteenth- and early twentieth-century historiography, in the general as well as his attacks on Alexandrowicz's assumptions in particular. ${ }^{196}$

\footnotetext{
194 See section 4, chapter 2, 108-113, for elaboration.

195 Alexandrowicz, C.H., An Introduction to the History of the Law of Nations in the East Indies, (Oxford, Clarendon Press, 1967)

196 Andaya, "Treaty Conceptions and Misconceptions," and The Heritage of Arung Palakka, respectively.
} 
To accentuate the issues raised by Andaya I shall also include the controversy between Paulusz and Arasaratnam over the Company's diplomatic interaction in Ceylon, ${ }^{197}$ because it illuminates the positions of Alexandrowicz and Andaya. I conclude with the positions of Somers and Van Ittersum before rounding off with a summary comparison of the respective positions.

\section{The nineteenth and early twentieth centuries}

The historiography of the nineteenth and early twentieth centuries did not understate the fact that there was a difference between the diplomatic habits and traditions of the Company and its Asian counterparts, and that this must be taken into consideration when analysing the nature of their interactions. Heeres, for one, elaborated on the implications of the overseas setting for the mode of the Company's performance in the following manner:

Through the behaviour of its sons in the Orient the Dutch national character has manifested itself in all manners, good and bad, but above all in a specific accentuation exacerbated by the environment in which it interacted, exacerbated by the antagonism between white and black, Christian and non-Christian, European and Asian. ${ }^{198}$

Another characteristic trait of nineteenth- and early twentieth- century historiography is its preoccupation with the Company's politico- diplomatic and military actions. ${ }^{199}$ As for the nature of communication with the Company's local partners, it was assumed that however unfamiliar the treaty terms were to them, they were still, in principle, intelligible. ${ }^{200}$ The latter view was not only held, but accentuated as a basic assumption in C. H. Alexandrowicz's 1967 book. Alexandrowicz's work remains a classic study in seventeenth- and eighteenth-century international law and the nature of the diplomatic interaction between Europeans and Asians in Asia. Compared to the nineteenth- and

197 Paulusz, “The 1638 Westerwolt Treaty in Ceylon,” and Arasaratnam, “J. H. O. Paulusz on the Westerwolt treaty in Ceylon: A Rejoinder."

198 "Het Nederlandsche volkskarakter heeft zich in de daden van Neerlands zonen in het Oosten vertoond in al zijn uitingen, in al zijn kanten; goede en slechte. ... Maar vooral in zeer bijzondere accentuatie, verscherpt door het milieu, waarin het daar optrad, verscherpt in de eerste plaats door de tegenstelling van blank en bruin, van Christen en niet-Christen, van Europeaan en Aziaat." Corpus Diplomaticum, 2. xvi-xii.

199 The selection of sources and comments in de Jonge, van Deventer, et al., De Opkomst van het Nederlandsch gezag in Oost-Indie and, Stapel's focus in Geschiedenis van Indië, may serve as exemplary cases.

200 See the discussion on Andaya's views on this below. 
early twentieth-century tradition, Alexandrowicz distinguished himself by his principled insistence on an essential similarity, and thus compatibility, between the thinking and practise of early modern international law in Asia and the West. He starts by admitting that initially there were differences in the Asian and Western systems of politico-diplomatic interaction, which originated in different conceptualisations of the nature of treaty making. For instance, the Asian systems and approaches were originally characterised by a "personal" approach, while those of the West by an "institutional" one. ${ }^{201}$ However, increased contact and treaty making possessed an inherent "law- promoting character," ${ }^{202}$ so that in the long run, a "depersonalisation" of the Asian conceptualisation towards an institutionalised interpretation took place. ${ }^{203}$ In other words, for Alexandrowicz, interaction was a dynamic process by which Asian accommodation to Western conceptualisations made their approaches increasingly similar.

A consequence of this was that up to the nineteenth century, the treaties between the Europeans and Asian rulers were basically concluded on an equal basis. ${ }^{204}$ It was against these propositions of compatibility and symmetry that Leonard Andaya came to launch his attack on what he considered to be Eurocentric misconceptions of Asian treaty making and diplomacy.

\section{Andaya versus Alexandrowicz}

In his 1978 article, Andaya declared his intention to "provide a fair and balanced analysis of treaty relationships between Europe and non- European states prior to the $19^{\text {th }}$ century." ${ }^{205}$ In diametrical opposition to Alexandrowicz, his main proposition was that European international law is irrelevant to understanding the nature of Europe-Asia treaty making before the nineteenth century. Rejecting Alexandrowicz's proposition of a "similarity of ideas of interstate relations and a mutual adaptation of legal concepts" ${ }^{206}$ between the Europeans

\footnotetext{
201 Alexandrowicz, Introduction to the History of the Law of Nations in the East Indies, 169.

202 Ibid. p. 176. For his views on the dynamics and development of politico-diplomatic relations between European and Asian rulers, see p. 203-204.

203 Ibid. 231.

204 Ibid. 224.

205 Andaya, "Treaty Conceptions and Misconceptions," 292.

206 Ibid. 276-77, quoting Alexandrowicz, An Introduction to the History of the Law of Nations in the East Indies.
} 
and their Asian treaty partners, Andaya argued the opposite position, namely that treaty making between Europeans and Asians from the seventeenth to nineteenth centuries represented a cultural collision because Asian conceptualisations were incommensurable with the European ones: "treaties between the Company and a South Sulawesi state were characterised by conflicting expectations, leading to frustration, then mutual recriminations, and finally war." ${ }^{207}$ A similar clash of positions can be found in an exchange between J. H. O. Paulusz and S. Arasaratnam.

\section{The Paulusz-Arasaratnam exchange on the Westerwolt Treaty}

In his 1980 article, "The 1638 Westerwolt Treaty in Ceylon: Charges of Dutch Deceit Disproved," Paulusz set out to clear the Company of charges of foul play in its conflict with the king of Kandy, Raja Singha, in the aftermath of the conclusion of the Westerwolt Treaty of 1638. Attacking views put forward by Arasaratnam and Goonewardena that the Company was consciously misleading the king, Paulusz holds that such charges are unfounded, and in fact should be reversed. While the Dutch had been "firmly upholding the basic terms of the contract against the king," the king himself had, for instance, been claiming, misleadingly, that he was the "emperor" of the whole of Ceylon. ${ }^{208}$ When the Dutch had been lured to support Raja Singha on such false pretenses, the king on his side had proven unable to live up to his promises of military support to the Company. Neither had he honoured obligations of cinnamon deliveries stated in their treaty. ${ }^{209}$

As a matter of fact, Raja Singha had been in breach of the treaty from the very outset as he had presented his motive for entering into an alliance with the Company as originating in their common goal of expelling the Portuguese from Ceylon. ${ }^{210}$ Yet, Singha also had another motive that he kept hidden from the Dutch, namely to seek support against a personal rival, Vijayapala. ${ }^{211}$

\footnotetext{
207 Andaya, "Treaty Conceptions and Misconceptions," 291.

208 Paulusz, "The 1638 Westerwolt Treaty in Ceylon," 321.

209 Ibid. 321.

210 Ibid. 323.

211 Ibid. 325 .
} 
As for the treaty concluded after the fall of the Portuguese fort in Batticaloa on May 18 , the king was given a draft of the treaty text which he spent a couple of days deliberating over with his advisors ${ }^{212}$ before finally signing it on May 23. The treaty was thus, claims Paulusz, "not a treaty imposed by a victorious general on a defeated enemy, but a Contract willingly sealed between brothersin-arms." ${ }^{213}$ For Paulusz, then, any notions of deceit and fraud by the Company are wrong because the treaty was entered into voluntarily by the Ceylonese, who were given time to consider its contents. ${ }^{214}$ For Paulusz, arguing from assumptions on a par with Alexandrowicz's , the Westerwolt Treaty was a symmetrical treaty built on universal terms of international law understandable to both the Ceylonese and the Company. If there was deceit involved, it came from the Ceylonese.

Arasaratnam came to disagree on all counts, and intensely so. Starting by referring to the unanimous opinion in the historiography that the Dutch "behaved with duplicity," ${ }^{15}$ he goes on to claim that Paulusz's arguments were "erroneous in the extreme." ${ }^{216}$ Paulusz produced no new evidence to support his case, his interpretations of the existing evidence were unacceptable, and he revealed an inadequate knowledge of the issues and background of the period. ${ }^{217}$

Arasaratnam calls Paulusz's interpretation of Singha's claim to be emperor of all of Ceylon fraudulent and an example of Paulusz's "ignorance of the philosophy and practice of state power in the island of Ceylon." ${ }^{218}$ The claim of universal kingship was "ingrained in Sinhalese kingship" as such. ${ }^{219}$ Arasaratnam also rejects Paulusz's proposition about Vijayapala, who, he notes, had nothing to do with the attack on Batticaloa. ${ }^{220}$ In other words, according to Arasaratnam there was no duplicity involved from Singha here either. After going through and rejecting Paulusz's reading and interpretation of the meanings and

\footnotetext{
212 Ibid. 325

213 Ibid. 325

214 Implying that they were thought to be able to comprehend its contents.

215 Arasaratnam, “J. H. O. Paulusz on the Westerwolt Treaty in Ceylon: A Rejoinder," 191-92.

216 Ibid. 193.

217 Ibid. 193.

218 Ibid. 193.

219 Ibid. 193.

220 Ibid. 194-95.
} 
intentions in the 1638 treaty point by point, Arasaratnam rounds out his criticism with an appeal for a revisionist, non-Eurocentric colonial history.

Prior historiography he divides into three phases, starting with the writings of the original Company administrators, which were taken over by the professional historians of the colonial era. Both these periods shared the colonizer's perspective, but the latter singled itself out by working professionally with colonial sources. ${ }^{221}$ Arasaratnam calls the third stage, which he dates from the 1950s, a revolutionary period, because it inaugurated a reaction to the previous Eurocentrism, a reaction based on a new consensus in that it was "no longer adequate to write the history of Europe's expansion in Asia solely as an extension of European history." ${ }^{222}$ Crucial for this reorientation and programme to avoid the pitfalls of the colonial sources, was to apply a more critical methodology. Paulusz, in Arasaratnam's eyes, fails to meet this essential requirement on all counts. ${ }^{223}$

I shall not be taking a stand on the Paulusz-Arasaratnam exchange here. Their respective positions in the debate primarily go to illustrate two points that are particularly relevant to my case. First, Paulusz's approach generally aligns with the nineteenth- and early twentieth-century positions of Company observance of international law and treaties, while Arasaratnam's criticisms generally is in accord with Leonard Andaya's anti-Eurocentric approach. Second, when Arasaratnam's criticizes Paulusz for failing to see the Sinhalese tradition and thinking on kingship in their own terms, the implicit assumption is that the Dutch not only brought their own standards overseas, but that they also operated from them without any effort to try to understand local traditions. This is an assumption close to Andaya's radical proposition of Eurocentric tunnel vision. One scholar who seems to try to balance these two positions in a moderate proposition is Jan A. Somers.

\section{Somers}

In this section, I address Jan A. Somers' positions on VOC diplomacy as put forward in his Thesis: De VOC als Volkenrechtelijke actor of 2001, and his book partly built on it: Nederlandsch-Indië-Staatkundige ontwikkelingen binnen een

\footnotetext{
221 Ibid. 202-203.

222 Ibid. 203.

223 Ibid. 203.
} 
koloniale relatie of $2005^{224}$. The main difference between the two is that while Somers presents the whole history of Dutch diplomatic interaction in Indonesia from the Company era up to Indonesian [what?] in the latter work, his Thesis is restricted to the Company period. Regarding the coverage of the Company period, in both works he uses Banten, Mataram, Ceylon and the Moluccas as his cases.

I shall briefly point to Somers' positions regarding international law and the conceptualisation of treaties in the Company period as they are depicted in both works. In general, I hold that Somers represents a view of the Company's diplomacy as pragmatic, although his view on this may be said to be more explicitly voiced in the 2001 Thesis than in the 2005 book. It should also be said, that although I endorse his views on the nature of VOC diplomacy, Somers is more preoccupied with the formally legal aspect of the interaction than with the actual practice of diplomacy, as for instance in negotiations, than I am. I shall treat the two works in chronological order.

\section{Somers 2001}

The volkenrechtelijke actor comprises twelve chapters in all. Chapters 1-7 deal with the conceptual framework and the historical background of the VOC up to the establishment of Batavia in 1619. In chapters 8-11 VOC diplomatic interaction with Banten and Mataram, the Moluccas, Ceylon and Cape the good hope, are analysed as cases of Company diplomatic interaction from the perspective of international law. In the final chapter, chapter 12, the conclusions are summed up chronologically.

Somers' focus is primarily on the way the Company saw itself as a diplomatic actor in various and changing contexts. Concerning the Banten case, Somers for instance distinguishes between two separate phases, namely the period between the establishment of Batavia in 1619, and the period after Banten's submission to the Company in 1684 . In the period up to 1684 the Company viewed its contracts with Banten as concluded between the

224 Somers, Jan A., De VOC as volkenrechtelijke actor, Proefschrift Erasmus Universiteit Rotterdam, Juni 2001, and Nederlandsch-Indië - Staatkundige ontwikkelingen binnen een koloniale relatie, Zutphen: Walburg Pers, 2005). From now on: Somers, volkenrechtelijke actor, 2001, and Somers, Nederlandsch Indië, 2005, respectively. 
governor-general as representing the Company, whereas after 1684 the governor-general acted as representing the States-General and the Prince ${ }^{225}$.

Mataram proves a contrary case to Banten, in that the Company never acted in the name of the States-General towards it, as it did towards Banten. Somers attributes this difference in approach to a difference in context and challenge. The need to keep European rivals out, i.e. the English from Banten, made stronger formal bonds necessary than in relations with Mataram, where no such external threats existed. ${ }^{226}$

Regarding the Ceylon case, the Company acted as instrument of the StatesGeneral in its contracts with the kingdom of Kandy, and again this is explained by the presence of a European rival, in this case the Portuguese. ${ }^{227}$ The Moluccas represented a special case compared to the three above because of the fragmented and weaker political structure dominating there, but as in the case of Banten and Ceylon, there were European rivals to be taken into account, namely the Spanish and Portuguese as well as the English. ${ }^{228}$ In the Moluccas the Company originally acted as an instrument of war on behalf of the StatesGeneral. But from 1651, with the signing of contracts of submission and the end of war with Spain from the second half of the 17 th century, the Company should no longer be considered as an actor in international law in the area ${ }^{229}$.

Cape the good hope is included in Somers' sample as a case of res nullius, and thus falls outside international law from the beginning. The Company personnel there acted solely as administrators on behalf of Batavia. ${ }^{230}$

The résumé of Somers' sample of cases above has been given to illustrate two general traits about his approach: Firstly, that his preoccupation lies with formal legal aspects of the Company's diplomacy, and secondly the formal legal interaction is considered in historical context. What is particularly relevant to my own topic in this connection is Somers' evaluation of the Company's assumptions and mode in its diplomatic dealings.

\footnotetext{
225 Somers, volkenrechtelijke actor 2001, 244.

226 Somers, volkenrechtelijke actor 2001, 245.

227 Somers, volkenrechtelijke actor 2001, 245.

228 Somers, volkenrechtelijke actor 2001, 246.

229 Somers, volkenrechtelijke actor 2001, 246.

230 Somers, volkenrechtelijke actor 2001, 247.
} 


\section{On the Company's assumptions and mode in its diplomatic dealings VOC mode}

It is basic for Somers that in the Company's diplomatic world de facto power held primacy over formalities of contract. This came from the fact that the diplomatic challenges that the Company was confronted with in Asia were never foreseen in 1602. The Company's diplomatic mode developed sui generis. ${ }^{231}$ Also, as for the Company's view on the function of contracts, Somers stresses that the Company hardly paid attention to the aspects of international law in the treaties: De Compagnie had meestal geen behoefte aan formeele volkenrechtssubbjectiviteit; de inheemse vorsten werden echter gefronteerd met, vergezeld van gangbare rituelen. ${ }^{232}$ It was this pragmatic view that made the Company able to navigate flexibly among the various customs of the respective courts it was dealing with. ${ }^{233}$

\section{Somers 2005}

In the 2005 book Somers starts his narrative of the Company period by stating that with the establishment of Batavia, the Company came to be perceived as and acted as an independent sovereign state in Asian waters. ${ }^{234}$ As for the nature of communication with the locals, he asserts that the Company came to encounter a "totally different cultural environment" in Asia. ${ }^{235}$ Regarding the kinds of states encountered in Asia, he notes that different typologies built on categories such as "agrarian," "harbour polities," or "communal states," or other ways of characterising them as, for instance, "feudal" or "patrimonial- bureaucratic," do not frame the problem adequately. ${ }^{236}$ He prefers to look upon them as "network states," understood as various nodes and concentrations in networks of commercial and diplomatic interaction that reached from Arabia to China and Japan. ${ }^{237} \mathrm{He}$ also takes care to stress the variety among Asian actors operating on the diplomatic stage, as for instance between Mataram and

\footnotetext{
231 Somers, volkenrechtelijke actor 2001, 247.

232 Somers, volkenrechtelijke actor, 2001, 247.

233 Somers, volkenrechtelijke actor 2001, 247.

234 Somers, Nederlandsch-Indië, 2005, 25.

235 "een volstrekt andere culturele omgeving." Nederlandsch-Indië, 2005, 25.

236 Somers, Nederlandsch-Indië, 2005, 33.

237 Somers, Nederlandsch-Indië, 2005, 34.
} 
the harbour states of Indonesia and the village communities of the Moluccas. ${ }^{238}$ Asian states prior to the coming of the Europeans all bore individual characteristics, ${ }^{239}$ but whatever their particularities, Somers' point is that these states had all long before the European maritime expansion upheld interstate contacts and interactions that were operated in a way that deserves to be considered as "international law." 240

This proposition of general similarity, and by implication of Eurasian compatibility, is one that Somers shares with Alexandrowicz. But to a greater degree than Alexandrowicz, Somers points to the difference between the pre- and post-nineteenth-century periods in holding up the early modern system in Asia as "incomparable" to the modern one. ${ }^{241}$ On this point Somers is closer to Andaya's positions than those of Alexandrowicz. On the other hand, he leans on the Eurocentric side when he judges the conceptualisation of treaty obligations of the Asian princes, as a "concession they could withdraw at will." ${ }^{242}$ Unlike Andaya, Somers does not elaborate on the possible Eurocentric cultural foundations for such a judgement. He simply states that facing such differences in conceptualisations and practices, the VOC diplomatic mode had to be, and indeed was, accommodating and pragmatic. ${ }^{243}$

All in all, Somers' recognition of particularities and differences never glides into a position of incompatibility as far as communication between Company and local polities or Company and rulers is concerned. Where Andaya sees a breakdown in Company-Makassar communication, Somers points to accommodation as, one must assume, a relative successful communicative means employed by the Company. Similarly, Somers explicitly subscribes to

\footnotetext{
238 Somers, Nederlandsch-Indie, 2005, 33-34.

239 "De volkenkundige constellatie in Azië, voorafgaand aan de Europese expansie, was vol eigenaardige aspecten, die doorwerkend in het Indisch staatsrecht, mede een stempel hebben gedrukt op de staatsvorming.", Somers, Nederlandsch-Indië, 2005Ibid. 35.

240 "Bovendien bleken de machthebbers onderling betrekkingen te onderhouden, zich te erdragen als volkenrechtssubjecten." Somers, Nederlandsch-Indië, 2005 Ibid. 34-35.

241 "In de toenmalige volkenrechtelijke constellatie, onvergelijkbar met de huidige internationale verhoudingen." Somers, Nederlandsch-Indië, 2005, 63.

242 Somers, Nederlandsch-Indië, 2005, 58.

243 "Wel heeft de Compagnie altijd getracht de door machtsverhoudingen feitelijk onstane situatie in te kaderen." Somers, Nederlandsch-Indië, 2005, 41, and "De Compagnie paste zich als koopman/vorst in het sociale en diplomatieke verkeer binnen de Zuidoost-Aziatische volkenrechtelijke constellatie volledig aan bij de binnen de vorstenhoven heersende gewoonten." Somers, Nederlandsch-Indië, 2005, 63.
} 
Alexandrowicz's proposition of functional understanding and increasing secularisation. ${ }^{244}$

To sum up, Somers does not advocate a position of structural blockage for communication, but points out that the Company often had to accommodate the other side for practical reasons. But still, if Asian and European concepts of international law were not instantly compatible, and European law consequently had to be accommodated to local standards, the question that needs to be answered is which factors shaped the accommodation of the Company's diplomatic practice and thus gave it a typical overseas "twist"? Alas, that is a question that Somers never really addresses. In his survey of the legal aspects of the VOC diplomacy and state interaction in Asia, the answer to this issue fades into the background.

Van Ittersum is the one in my sample who comes closest to offering a characterisation of VOC diplomacy in practice within a broader historical framework. She proposes that the Company's legal theory was but a vehicle for politics of power. According to her, the Company not only held a pragmatic view on the use of law overseas, but an outright cynical one.

\section{Van Ittersum}

One of Van Ittersum's objectives is to remedy what she considers to be shortcomings in the Cambridge school of political thought. Although the school must be credited for having disclosed "the dark side of rights theories," such as demonstrating the thinking of Grotius, Hobbes, and Locke as "building blocks of Western Imperialism, ${ }^{245}$ its approach still has clear deficiencies. For one "its methodology does not always seem compatible with its self-proclaimed mission to write the history of political thought." ${ }^{246}$ Instead, it seems to be locked within the confines of philosophical study. ${ }^{247}$ What are lacking, claims Van Ittersum, are an awareness of historical context and an analysis of "the histo-

\footnotetext{
244 Somers, Nederlandsch-Indië, 2005, 46, referring to Alexandrowicz, Introduction to the History of the Law of Nations in the East Indies, 89.

245 Van Ittersum, Profit and Principle, xxxvii.

246 "If the Cambridge school is gradually broadening its scope ... its methodology does not always seem compatible with its self-proclaimed mission to write the history of political thought." Ibid. xl.

247 "remains preoccupied with the canon of Western philosophy." Ibid. xli. "Although the Cambridge School continues to maintain a refreshingly critical stance towards the cannon of Western philosophy, it refuses to abandon the notion of a canon as such." Ibid. xlii.
} 
rical events that inspired or provoked the writings of early modern theorists and that these theories themselves hoped to influence." ${ }^{248}$ What she advocates is an analysis of the "interrelationship between politics and political theory," ${ }^{249}$ and this is what she herself sets out to do in Profit and Principle, which examines the relationship between Grotius's legal theories and the Company's enterprise and interests.

\section{Positions}

The point of departure for Van Ittersum is that Grotius's legal theories were intrinsically bound to the interests of the Company. For its part, the VOC context was marked by the world of aggressive military and naval strategies in which the Republic was born, ${ }^{250}$ and run by capitalist directors who were themselves cynical and opportunistic. ${ }^{251}$ For all the sophistication of form and level of abstraction, Grotius's thinking was part and parcel of this world. "Even though he conceptualised this material at a higher level of abstraction than anybody else," writes Van Ittersum, "his theoretical concerns were always subject to the VOC's political needs and commercial interests." ${ }^{252}$ When Grotius was bound by and committed to the interests of the Company in this way, his text must also be interpreted in that context: "Grotius did not philosophize for philosophy's sake. He wrote De Jure Praedae and published chapter 12 as Mare Liberum to safeguard the VOC's commercial interests and political needs. ${ }^{253}$ In other words, Grotius's legal theories constituted a "key component of Western imperialism and colonisation in the early modern period." ${ }^{254} \mathrm{His}$ theories were thus not only contemporary with, but intrinsically built into and directly instrumental to the venture of early modern mercantile expansion: “Grotius' rights and contract theories were not just coterminous with the rise of global

\footnotetext{
248 Ibid. xliii.

249 Ibid. xliii.

250 "The VOC itself was a product of the aggressive military and naval strategies of the Dutch Republic at the start of the seventeenth century." Ibid. lii.

251 VOC directors: "hard-headed capitalists and opportunistic to the core." Ibid. lii.

252 Ibid. liv.

253 Ibid. lxi.

254 Ibid. lxi.
} 
trading empires in the seventeenth and eighteenth centuries, but made them possible in the first place." 255

It is a central proposition for Van Ittersum that once Grotius is identified as a Company spokesman and agent, his cynicism comes clearly to the fore. For example, De Jure Praedae was written in defence of Van Heemskerck's capture of the Portuguese ship Santa Catarina at the explicit request of the VOC directors. ${ }^{256}$ Likewise attached to Company interests, and thus opportunistic, was Grotius's defence of "the Black Legend," which he used for all it was worth to legitimize Dutch privateering against the Iberian enemy. ${ }^{257}$ Van Ittersum's most prominent proposition about Grotius's cynicism is however the nature of his contract theories, which she considers a kind of fraud by law.

\section{Grotius's treaty theory: Fraud by law}

Grotius's contract theory rested on the recognition of the local parties as legitimate legal subjects. Therefore, they were by natural law free to sign treaties with whomever they wished, but once a treaty had been signed, they were committed to keep their obligations by the principle of pacta sunt servanda (agreements must be kept). Thus, the VOC's monopoly treaties "contained no escape clauses. Once signed, the local signatories were obliged to ensure that their subjects sold their manufactures to the VOC in perpetuity." ${ }^{58}$ During the London conference in 1613 and 1615, in which Grotius negotiated for the Company, he systematically defended the right to take up arms to defend the monopoly treaties, even if it meant taking up arms against the local population. 259

The trick here, holds Van Ittersum, is that Grotius does not bring the imbalance in strength into the reckoning. Because of its relative weakness of power, the Spice Islands in practice "had little choice but to renew their contracts with the VOC year after year. They simply lacked the military means to dislodge the Company from their countries. Grotius blatantly ignored these power differentials in his rights and contract theories." 260

\footnotetext{
255 Ibid. lxi

256 Ibid. lv.

257 Ibid. lv.

258 Ibid. xxii.

259 Ibid. xxii.

260 Ibid. lx-lxi.
} 
Grotius's rights and contract theories served two purposes: To undermine Iberian claims to the extra-European world and to legitimize Dutch participation in the age-old trading systems of the Indian Ocean and the China Seas. ${ }^{261}$ In the latter area, more specifically the Indonesian archipelago, the Company's tactics and mode of operation were to lure or pressure local rulers into treaties that were beneficial to the Company. When the former came to realise that the treaties ran contrary to their own interests, the Company could defend them on Grotian principles by claiming that they were entered into without coercion by autonomous subjects of law, and thus were legally binding and had to be observed.

\section{Summing up: Ittersum}

Grotius is the "villain" in Van Ittersum's story as he is the one who gave the Company the legal theory to justify their behaviour after the fact. In other words, he provided the opportunity to suppress local states by legal trickery. One assumption Van Ittersum shares with Andaya is that local people had an imperfect understanding of the implications of agreeing to treaties with the Company. But Van Ittersum's emphasis is different. It is not the miscommunication in itself which is her point; it is the fraudulent way in which the company manipulated partial understanding or misguided interpretations in its treaty practice. This point also contrasts with the approach of the nineteenthand early twentieth-century tradition, as well as Somers' view, in that Van Ittersum primarily analyses law in terms of power relations and as a means of extortion. When and where power relations were asymmetrical to the advantage of the Company, "law" could and did become a cynical instrument for achieving the Company's ends.

\section{Section 6: Summing up the historiography of VOC diplomacy}

Five approaches to the understanding of the nature of seventeenth- century VOC diplomacy and the nature of its interactions in Asia have been identified above. The classical approach of the nineteenth and early twentieth centuries

261 Ibid. lxi. 
recognised differences in conceptualisations and practice, but still assumed a functional understanding between the Company and its Asian partners. The "the system compatibility approach" represented by Alexandrowicz advocated both a level of compatibility in thinking about international law at the outset as well as cumulative cross-cultural understanding by increased interaction. Andaya heavily attacked this approach, and advocated a cultural embeddedness approach that emphasized conceptual incompatibility and structural miscommunication as typical of pre nineteenth century East- West state interaction. Somers' "legal-pragmatic approach" may be regarded as a variant of the nineteenth- and early twentieth-century approach, though it should be distinguished from the former by being more explicit about its emphasis on cultural differences. Van Ittersum for her part shares the preoccupation with law with both classical historiography and Somers, but marks herself off by analysing law as primarily an instrument of power. The discussion between Paulusz and Arasaratnam marks no original positions on its own, but is primarily used to clarify the difference in positions between Andaya on the one hand and the nineteenth- and twentieth-century historiography and Alexandrowicz on the other.

I propose that the approaches I have treated here, with the possible exception of Van Ittersum, and with some modifications for Somers, "over-focus" on law as far as the nature of the Company's diplomacy is concerned. By that I mean that they all seem to assume a direct and decisive impact of concepts of European international law on the Company's diplomatic practice. I suggest not only that this was not the case, but that this misapprehension leads to a distortion of a relevant conceptualisation of Batavia's diplomatic practice proper, by underplaying both its thoroughly pragmatic and case-oriented character and, not least, its dynamic nature.

There are some propositions in the above survey with which I particularly differ. I hold Andaya's assumptions and propositions about the Eurocentric nature of VOC diplomacy to be anachronistic in that he seems to transfer nineteenth-century conceptualisations of treaty law to a seventeenth-century world of commerce by treaty. This has in its turn implications for his propositions about the structural misunderstanding in communications between Makassar and the Company. I think Andaya wrongly rejects the reciprocal understanding there was and underrates the dynamics of the Company's understanding. I also object to the all- embracing pretensions that seem to be 
implied in Van Ittersum's propositions about the Company's cynical application of treaties. It may fit well in the smaller states in the Moluccas, but probably not in the Moluccas in general, and certainly not in the charter area as a whole. And, as a generalisation, it is contradicted by the instances of idealism that can be found in the Company treaties.

In the next chapter, I shall first analyse propositions about the nature of VOC diplomacy particularly as they come forth in Andaya's analysis of seventeenth-century VOC-Makassar diplomatic interaction, and then elaborate on my own propositions. 



\section{2 \\ Positions and Propositions Refined}

In this chapter, I turn specifically to the historiography on Makassar. I shall start by briefly introducing F. W. Stapel's now classic thesis of 1922 before concentrating on Andaya's views on the contrasting nature of South Sulawesian and European diplomacy. In a separate section, I contrast Andaya's views to Resink's view on Makassarese international law to clarify my own positions. Finally, I present the structure of my argument and plan of exposition in the empirical chapters, before I round off with some comments on sources and method.

\section{Section 1: Brief historiography on seventeenth- century Company-Makassar interaction, with an emphasis on Andaya's propositions}

F. W. Stapel's Het Bongaais Verdrag is a monograph on the Company's interaction with Makassar from the early seventeenth century up to the Bongaya Treaty. Stapel focuses on the political and diplomatic interaction, and the text is organised in a chronological narrative with analytical comments inserted. However, the analytical implications are more often hinted at than fully explicated. Typical is Stapel's remark that the behaviour of the Makassarese "did not come as a surprise to those who knew their nature."' This should not be read as a racist remark; "the nature of the Makassarese" should more likely be read as "culture" or "habitual way of doing things."

However, the remark leaves some assumptions uncommented. It combines an explicit proposition of difference and the implicit assumption that the

\footnotetext{
F. W. Stapel: Het Bongaais Verdrag, PhD diss., Leiden University, 1922.

"voor hem, die den aard der Makassaren kende." Ibid. 34.
} 
Company in spite of such difference, had been able to decipher the Makassarese code of conduct. In other words, Stapel operates from assumptions that there were differences in codes of behaviour between the Company and Makassar but that they did not prevent the Company from having a functional understanding of the situation. In other words, their respective systems of interaction and communication were compatible to a degree that enabled the Company to have a meaningful interpretation of the Makassarese system. Such propositions of compatibility and the possibility of functional understanding came to form the main targets of Leonard Andaya's two publications on the diplomatic interaction between Makassar and the Company, ${ }^{3}$ which appeared almost fifty years after Stapel's work.

In his analysis of the VOC's diplomatic interaction with Makassar, Andaya vehemently rejects Stapel's assumption that the Company's personnel were capable of understanding the nature and therefore the "ways" of the Makassarese. On the contrary, he holds that for South Sulawesians and the Company, the meaning of state interaction and treaty were totally incompatible. Thus, there was no foundation for meaningful communication between the two. The diplomatic communication between the Company and Makassar represented a structural miscommunication grounded in antagonistic political cultures and perceptions.

I shall clarify Andaya's positions about the incompatibility between South Sulawesian and European diplomatic conceptualisations with a focus on his propositions and assumptions about the nature of the VOC's overseas diplomacy primarily using his 1978 article as my reference.

\section{Spiritual versus secular conceptions of "treaty"}

The basic difference between the Dutch and South Sulawesian conceptions of how treaties functioned was that while the Western tradition operated within a secular, rational logic, the South Sulawesian tradition was confined within sacred, mythical beliefs and perceptions. Andaya builds to a large degree on Noorduyn's Een Achtiende-Eeuwse Kronik van Wadjo - Buginese Historiografie. ${ }^{4}$ Hans Hägerdal and William Cummings represent more recent elaborations of

\footnotetext{
Andaya, “Treaty Conceptions and Misconceptions," and The Heritage of Arung Palakka.

Proefschrift, Universiteit te Leiden, 's Gravenhage, 1955.
} 
similar views. ${ }^{5}$ Writing about Timor and the eastern Indonesian archipelago Hägerdal for instance prefers the terms "princedom" or "domain" instead of "kingdom" to cover the non-bureaucratic nature of the polities there, ${ }^{6}$ and points to Henk Schulte Nordholt's use of the term "Mandala state." ${ }^{\prime}$ Hägerdal himself uses the term "kingdom of word" to describe the "spiritual or symbolic essence of such polities), ${ }^{8}$ Immanent in the "symbolic" conceptualisation of power is also a conceptualisation of "history" that is different from the modern Western standard. In the "sacred world view" there was no term for "myths", indicating the nonexistence of the Western distinction between "myth" and "fact." ${ }^{\circ}$ The Solorese, in the words of de Roever thus had no "history" in the Western sense, only oral, "mythological history." ${ }^{11}$ It is with this background that we must view William Cummings' statement that "no Makassarese (historical) chronical ever set out to rewrite or interpret what had been set out in a previous text." ${ }^{12}$

Gerrit Knaap is also pointing to the same logic when he characterises the mentality on Ambon as backwards-looking with an emphasis on honouring the tradition with a belief in spirits in the guise of forefathers to guard and protect it. ${ }^{13}$ The "conceptual package this springs from is one where everything is interpreted as "signs" and "warnings." 14

Having demonstrated that Andaya both stands in a tradition preceding him of emphasising the peculiar sacral or mythological foundations of society and polity in maritime Southeast Asia him and that this tradition is still vital, I shall return to his treatment of it as a determining factor in the understanding of the logic of state-interaction and diplomacy in the region.

Hägerdal, Hans, Lords of the land, lords of the sea: conflict and adaptation in early colonial Timor, 1600-1800 Leiden: KITLV Press, 2012, and: Cummings, W., Making Blood White: Historical Transformations in Early Modern Makassar. Honululu: University of Hawai'I Press, 2002, respectively.

$6 \quad$ Hägerdal 2012, 5, n. 7 .

$7 \quad$ Hägerdal 2012, 171 n. 76.

8 Hägerdal 2012, 61 and 69-70.

9 Hägerdal, 2012, preface, xi.

10 Hägerdal 2012, 74.

11 de Roever, 2002, 20.

12 Cummings, 2002, 48-49.

13 Gerrit Knaap, Kruidnagelen en Christenen: De VOC en de bevolking van Ambon 1656-1696, tweede herziende druk Leiden: KITLV Uitgeverij, 2004, 90.

14 Knaap 2004, 91. 
Andaya considers what he calls "the spiritual element" of the treaties, "as important as the political to South Sulawesi states." ${ }^{15}$ In fact, he asserts that a predominantly "spiritual" orientation as opposed to a this-worldly approach formed the defining trait of South Sulawesian diplomacy and treaty making up to the twentieth century: "A South Sulawesi ruler prior to the $20^{\text {th }}$ century was also a product of his culture and time, and while he was mindful of the secular world, he was equally, if not more so, responsive to the spiritual one." ${ }^{16}$

In introducing this statement, Andaya also warns that such a mythological worldview or mode of perception is hard to grasp for "the cynical modern-day observer ... tempted to see everything in terms of Realpolitik." ${ }^{17}$ Andaya's implicit historical comparative argument is that in the seventeenth and eighteenth centuries, European treaty partners with Sulawesian states did not understand the kind of logic and mentality the local actors were operating from, set as they were in their own kind of rational thinking and rational tradition. When Europeans met with the spiritual South Sulawesian tradition, it was a clash of cultures, a confrontation between two incompatible worldviews. ${ }^{18}$

The "cosmological," "sacred," and ritual nature of South Sulawesian diplomatic treaties was embedded in oral traditions and lived on when these were written down. This can be seen in the "ritual-like repetition of certain phrases," ${ }^{19}$ and the phrases used for "treaty," such as "to give one's word of honour," "to uphold or support one's word," and the like. ${ }^{20}$ The introduction of the written treaty was thus simply seen as "an extension" of the older, oral tradition..$^{21}$ The logic and meaning of the oral tradition was thus carried over to and came to be contained in the written tradition. The essential point that Andaya wants to make is that the act of putting treaties into writing did not mean a transition into a new conceptualisation, but a continuation of the sacred logic in a new form.

The sacred or "cosmological" conceptualisation of treaty making in the South Sulawesian tradition also revealed itself in the ritual modes of confirming treaties, and the sanctions invoked for breaking them. The traditional confirmation ritual by drinking palm wine that had been stirred by the

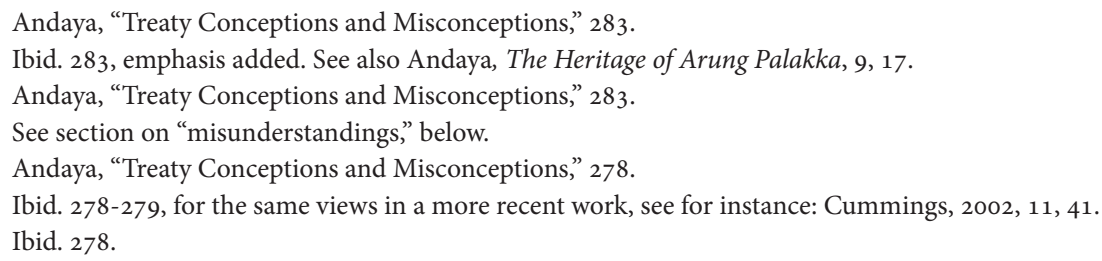


overlord's kris or sword of state reflected, for instance, the perception that the kris was believed to imbue the potion with its powers. ${ }^{22}$ When treaty obligations as a rule were made binding for present, as well as future generations, it pointed in the same direction of a magical worldview. ${ }^{23}$ Also, making the extinction of lineage the ultimate sanction for breaking the treaty underlined the "immense importance attached to the survival of the king's line." 24 The threat at least reflected the lineage logic in South Sulawesian society, where lineage formed the basic social and political structure. ${ }^{25}$ It was with such notions of spirituality and collective survival that South Sulawesian states made treaties with each other, and-this is the basic assumption in Andaya's argument-it was with such conceptualisations and expectations that Makassar concluded treaties with the Company, and which lay at the heart of their miscommunication. ${ }^{26}$

One should note that Andaya's proposition of an antagonistic difference between the South Sulawesian and European conceptualisations of state interaction rests on two basic assumptions. The South Sulawesian religious or sacred conceptualisation and mode of operation stood in such absolute contrast to those of secular Europeans as to make meaningful communication or interaction between the two impossible. Furthermore, Andaya does not consider the possibility that either party could apply modes of thinking and operation that differed from those inscribed in their respective cultural models of state- interaction. Both were locked within and unable to transgress their respective monolithic cultural models.

\section{South Sulawesian and Western functions of treaty and function of state-interaction systems contrasted}

The point of departure in Andaya's comparison between treaty making in Europe and South Sulawesi is that while the Western tradition operated within a secular, rational logic, the South Sulawesian tradition was confined within sacred, mythical beliefs and perceptions. From this it follows that the concrete form and function of treaty making was basically different, too. For instance, the South Sulawesi treaties

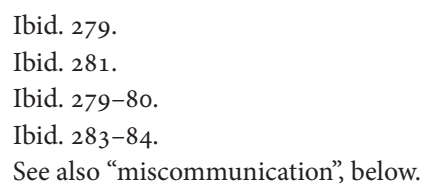


had a particularly localised function and meaning that could be found in the preamble, where the "precise relationship of the treating parties was declared in purely conventional terms. ${ }^{27}$ These "precise relationships" ranged from full equality to master-slave relationships. ${ }^{28}$ These hierarchical relations were expressed in terms of closeness of family relations, like father and son, elder and younger brother and so forth ${ }^{29}$ This system further meant that once the type of hierarchical relation was given, it became "superfluous to mention particular details already implied in the conventional phrases." ${ }^{30}$ This mode of giving the specific obligations and rights by inference from hierarchical relations, with "no possibility of ambiguity" according to Andaya, ${ }^{31}$ stood in diametrical opposition to the typical European mode, in which rights and obligations were expressively stated in the specific: the Dutch and the native states] differed fundamentally in the manner in which they invoked the treaty as a legitimising document. Whereas the Dutch would cite a specific provision within the detailed Bongaya treaty, the native states would simply refer to the treaty' without mentioning any specific clause." ${ }^{22}$ In the South Sulawesian perception and practice, stating specific rights and obligations was superfluous. In the European perception, such specifics were the primary task of treaty making. These conflicting technical modes of treaty formulations accordingly reflected conflicting modes of perception as to what a "treaty" really meant. At the heart of the matter lay the basic difference between the South Sulawesian and the Western traditions where the former was of a "spiritual-" and the latter of a secular nature.

\section{A spiritual conceptualisation of interstate relations: The workings of the South Sulawesian system and grounds for structural misunderstandings, and conflicting views on the nature and bonds of treaties}

The spiritual primacy in treaty conception meant that no treaty once concluded was ever considered totally dead and done with. On the contrary, it was thought of as a perpetual part of the sacred lineage heritage: "The words and oaths of the ancestors

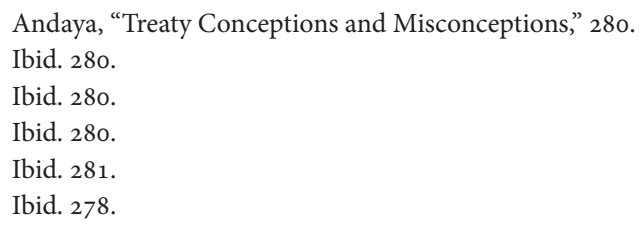


contained in the treaties became a moral and supernatural sanction which adumbrated all interstate relations." ${ }^{33}$ This conceptualisation not only provided stability" ${ }^{34}$ but also gave flexibility and dynamism to the interstate-system in South Sulawesi. For, when actual power centres changed and prior alliances were broken and new formed, obsolete treaties were relegated to the shadows of the new ones, but with the possibility of re-emerging should changes in the actual power relations require it: "Once a treaty had been agreed upon, it remained a permanent agreement which could be resurrected and renewed or allowed to recede into the background in face of other superior political and spiritual forces." ${ }^{35}$ The notion of treaties as "enduring sacred documents" was thus no impediment to stability or dynamic readjustments; quite the contrary, it served as a facilitating factor for both: "The treaties, oaths and the whole treaty making procedure were part of a continuing process of reassessment of political and spiritual affiliations to assure the establishment of a hierarchy of states which accurately reflected the power situation in South Sulawesi." ${ }^{36}$

As for flexibility, Andaya goes so far as to rank the South Sulawesi states diplomatic system as superior to the Company's, because in the latter, treaties were used and functioned as "instruments of oppression," ${ }^{37}$ whereas in the former they served as "a means of establishing proper and peaceful relations." 38 Leaving aside the ranking and the moral context that Andaya puts it in here, his explanation of motivating forces and the driving factor "' in the South Sulawesian system demands comment. Unique moral conceptualisations of "honour" (siri) and "dignity" (pesse) formed the underpinnings of the South Sulawesian states system, and represented a logic that stood in diametrical opposition to the European diplomatic system.

\section{The concept of siri and the workings of diplomacy and treaty in the South Sulawesi states system}

Distribution of siri, a concept that may be translated as "shame," "self- respect," or "self-worth," ${ }^{39}$ was what the typical South Sulawesi system of treaties was

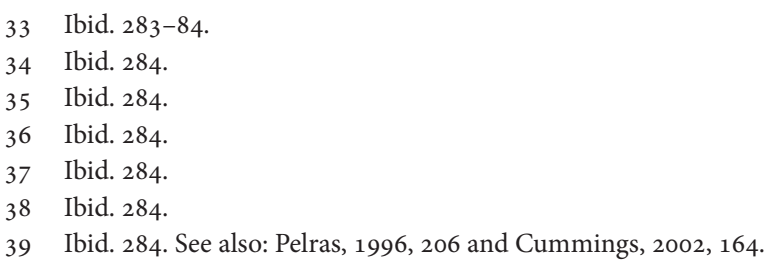


about. Diplomacy was a mechanism by which proper and peaceful relations with other states were established by distribution and redistribution of it." ${ }^{\circ 0} \mathrm{At}$ the personal level, siri worked as motivational factor. To have siri meant "to know one's status and place in one's society," and a person would "defend his self-respect to the death if necessary." ${ }^{41}$ The struggle for recognition of siri, and conversely the fear of being deprived of it at the personal individual level, was replicated in the political life of interstate relations. The instrument in which political siri was gained was the treaty: "A similar philosophy appears to have underlined the concept of treaties in South Sulawesi. A state's understanding of its proper status in relation to all other states was determined by the treaty." ${ }^{42}$

Recognising the siri mentality as the driving factor in the South Sulawesian interstate system has serious implications for the understanding of the particular logic of treaty making in South Sulawesi, because the siri-logic meant that the primary goal of the treaty was to preserve social harmony: "The efficacy of the treaty lay, as with 'siri', in the universal acceptance in South Sulawesi of its legitimate function in preserving harmony in the society." ${ }^{43}$ The implicit contrast is with the Western treaty as a zero-sum game in which one party always must lose. So, for Western Europeans and South Sulawesians, the purpose and way of treaty making constituted a binary, contrasting pair not only at the conceptual level, but also for their inherent logic and motivating factors. Furthermore, in Andaya's view, these were not differences of degree but of kind. As such, they constituted a structural impediment to meaningful communication, and hence for systemic misunderstanding between the Company and South Sulawesian states like Makassar.

\section{Miscommunication in treaty making between Makassar and the Company}

The seventeenth-century contractual record between Makassar and the Company up to and including the Bongaya Treaty serves as Andaya's main example of systemic misunderstanding. It is central to his argument that the Makassarese were inexperienced in the Western mode of treaty making. Thus,

\footnotetext{
40 Ibid. 285. For these concepts, see also Andaya, The Heritage of Arung Palakka, $15 \mathrm{ff}$.

41 Andaya, "Treaty Conceptions and Misconceptions," 284.

42 Ibid. 284.

43

Ibid. $284-85$.
} 
he stresses that there is no evidence of any treaty making with the Portuguese, and that the treaties with the VOC of 1637,1655 , and 1660 , represented the only three previous occasions in which the sultanate had entered into "a formal treaty arrangement with a European power prior to the one of 1667. " 44 Likewise important to Andaya's proposition of structural misunderstanding is that there was no learning either. Andaya regards the Bongaya Treaty as exemplary when it comes to structurally conditioned misunderstandings originating from the underlying divergence in the way the Company and South Sulawesian states understood the concept of the treaty. ${ }^{45}$ To the degree that there were exceptions, these can be explained as exceptions that prove the rule.

\section{Exceptions confirming the rule in the Company's treaty practice}

The Company, says Andaya, "was not unaware of the existence of local treaty traditions in South Sulawesi as it "actually became party to such treaties." ${ }^{6}$ But special contextual factors go to explain the rare instances where the Company made concessions to local norms. Accommodation to indigenous treaty traditions happened in cases where the Company was weak, such as when concluding the 1655 treaty with Makassar, ${ }^{47}$ or in dealings with native states from which the Company had nothing to fear, such as four treaties concluded in December 1671 with minor South Sulawesi states the Company considered insignificant. ${ }^{48}$ Andaya's explanation of these exceptions is that the Company would depart from its own contractual tradition either when it felt itself bargaining from a weak position, or from a position of disproportionate strength in its favour.

Looking at Andaya's use of the 1655 treaty as an example of Company accommodation to local standards in more detail, one of the accommodations he sees is that although "the framework of the treaty is borrowed from the Western European practice of including each new subject in separate

\footnotetext{
44 Ibid. 289 (referring to Stapel, Het Bongaais Verdrag, 33-34, 53, 66-77).

45 Andaya, "Treaty Conceptions and Misconceptions," 289.

46 Ibid. 286.

47 December 28, 1655 treaty with Makassar, see analysis in Chapters 4 and 5 .

48 Andaya, “Treaty Conceptions and Misconceptions," 287.
} 
numbered articles, the contents read like a typical South Sulawesi treaty." ${ }^{49}$ The local imprint by contents is demonstrated in three articles safeguarding the autonomy of Makassar. ${ }^{50}$ As for form, local influence shows itself in general or imprecise phrasings of the treaty clauses, which only in article $8^{51}$ does "again revert to the precision of a European document." ${ }^{2}$

\section{The 1671 treaties}

In cases where the Company felt it held the upper hand, accommodation to local forms concerned the vassal-overlord relationship, in which the Company was recognised as ruler in the "traditional South Sulawesi treaty idiom." Another example Andaya uses is the fact that the swearing of the treaty also took the traditional form by swearing on the Koran and drinking the ritual palm wine "all in the traditional fashion." ${ }^{33}$ But all in all, apart from the 1655 and 1671 examples, both of which were marked by exceptional circumstances, the general rule was that the Company's ideas about Asian rulers and treaty making with them were locked in Eurocentric perceptions and practices. However, local contractors interpreted these Eurocentric treaties in terms of local idiom. Andaya uses the Bongaya Treaty as a prominent example of both.

\section{The Bongaya Treaty of 1667}

After demonstrating how Arung Palakka perceived the Bongaya Treaty in terms of local conceptions and how he continued to act in accordance with these conceptions vis à vis the Company, ${ }^{54}$ Andaya goes on to argue that this was the general South Sulawesi interpretation of the Bongaya Treaty. Arung Palakka and his allies thus viewed their relationship with the Company as "a favoured child to the mother" 55 and according to local tradition, this type of relationship carried certain obligations for the "mother" as the person responsible for the protection and welfare of its "child": "When the South Sulawesi

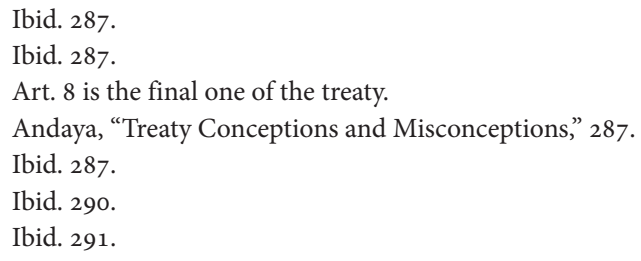


states accepted their subordinate relationship to the Company in the Bongaya treaty, they fully expected the Company to accept its responsibilities as mother/ master and guarantee the sovereignty of all its children / slaves in the traditional South Sulawesi overlord-vassal relationship." 56

When the Company, acting on their own set of conceptions, failed to meet local expectations, the South Sulawese considered the treaty to have been broken: "But this expectation turned to bewilderment and anger when the Company failed to adhere to the proper code of behaviour expected of an overlord." 57

The examples that Andaya uses to illustrate the Company's failure to meet South Sulawesians' expectations mainly concern Sulawesian fears of the Company's infringements on local autonomy. ${ }^{58}$ Over this issue, there was a constant struggle in which the Company tried to "force" the South Sulawesi states into the European conceptions of treaty. ${ }^{59}$ But these states "never relinquished their traditional belief that any treaty guaranteed a state's right to its own adat and bicara." ${ }^{60}$ Basically, this too was a conflict caused by incompatible expectations grounded on conflicting assumptions about the meaning of "treaty" and, no less important, how treaties function.

\section{European tunnel vision and lack of understanding of and sensitivity to local perceptions in the Company's treaty making}

Andaya describes the Company's approach to its Asian counterparts as based on three features: A principled lack of intention to understand the local treaty traditions; an all-embracing dominance of the "European" model in the Company's treaties with states in South Sulawesi; and a lack of interest in accommodating local practices. "There is little indication that any effort was made to understand the whole intent of local treaties," he writes. "Almost the entire corpus of the treaties between the Company and the South Sulawesi

$\begin{array}{ll}56 & \text { Ibid. } 291 . \\ 57 & \text { Ibid. } 291 . \\ 58 & \text { Ibid., } 291 \\ 59 & \text { Ibid. } 291 \\ 60 & \text { Ibid. 291, "customary law" and "autonomy." }\end{array}$ 
states was framed in the Western European tradition of treaty making, with little or no attempt to accommodate local practices." ${ }^{11}$

Andaya's message is clear: Company servants suffered from a form of Eurocentric tunnel vision. They brought with them a Western model of "treaty" to Asia and made no adjustments when applying it in the Asian context. Given that the "European beliefs and concepts" brought overseas were in total opposition to local perceptions, the treaty making by necessity had to end in a clash of cultures. I shall end my exposition of Andaya's viewpoints by demonstrating how conflicting conceptualisations of "treaty" lay at the heart of the Company's recurring complaints about "breaches of contract" by its South Sulawesian opposites.

\section{Allegations of breach of contract as a cultural misconception}

As we have seen, Andaya claims that the difference between the Company and its South Sulawesian counterparts' conception of what a treaty was can be ascribed to the fact that the Company's intention was to establish regulations on specific issues to which both parties agreed, whereas the South Sulawesian intention was to signal positions within a hierarchy of implicit, but still specific reciprocal obligations. A divergent view of what constituted a breach of contract was thus built in at the outset. For the Company, it followed that any failure by the treating parties to honour the explicit regulations agreed to in the treaty was considered a violation of its terms. From the South Sulawesian point of view, however, such explicit and specific regulations were peripheral to the intention of entering into a treaty at the outset, as the centrality of the agreement lay in its function as a regulator of a given state's position and thereby implicit rights and obligations within a hierarchy of states. In South Sulawesi the state interaction system was set in a mental framework in which "the local states viewed the treaty not in its individual parts, but as a total document." ${ }^{62}$ It all meant a deep-seated difference between the South Sulawesi states and the Company regarding the view of what constituted breach of contract. In South Sulawesi, "the treaty represented an open declaration of a shift in the spiritual

\footnotetext{
61 Ibid. $287-88$.

62 Ibid. 288 .
} 
and political power relationships in the area, and ... when circumstances demanded it, the ruler felt free to re-examine his alternatives and to make necessary realignments to reflect the new power relations." ${ }^{33}$ By the Company's particularistic standards, however, such rearrangements came to be regarded as "breaches of contract. ${ }^{6}$ It all boiled down to the essentially antagonistic conceptualisation of the meaning and function of treaty as respectively a secular political or spiritual political entity.

To the local South Sulawesi treaties represented a mechanism for the distribution of political and spiritual "capital." To the Company, these treaties were intended as a political means for acquiring profit: "The treaties between the Company and the native states were ... always basically commercial with the foremost aim being the acquisition of trading advantages for the Company." ${ }^{65}$ The South Sulawesi treating parties did not put much emphasis on commercial matters, which were always secondary and instrumental to political and spiritual concerns or considerations about hierarchical position. ${ }^{66}$

In general, Andaya purports that the very idea of entering into treaty relationships for commercial purposes was not an integral part of the South Sulawesian perception of "treaty": "Such a treaty whose central concern was trade was totally alien to the concept of treaties in South Sulawesi." ${ }^{67}$ So, not only were the European and South Sulawesian treaty traditions different in form and content, they served fundamentally different purposes.

Besides that, the wording of the Company's treaty regulations was formulated so intricately that the local ruler was left with no other option but to protest against the most "outrageous" of them, while leaving the rest in the belief that "all things would find their proper place according to well-known traditional practices." 68 The latter assumption was an expectation that sprang from the Sulawesian tradition, in which it was assumed that the commercial or economic arrangements would find their solution within a framework of reciprocal rights and obligations that did not compromise any of the party's sovereignty. ${ }^{69}$

$\begin{array}{ll}63 & \text { Ibid. } 288 \\ 64 & \text { Ibid. 288 } \\ 65 & \text { Ibid. 288. } \\ 66 & \text { Ibid. 288. } \\ 67 & \text { Ibid. 288. } \\ 68 & \text { Ibid. 288. } \\ 69 & \text { Ibid. 288. }\end{array}$ 


\section{Summing up of the subsection}

Whatever the contextual reasons Andaya offers to explain the exceptions to the VOC's mode of treaty making, in the main he offers a structural explanation for the typical meaning and mode of diplomatic practice by both the Company and the South Sulawesi polities. Because these meanings and modes sprang from incompatible conceptualisations, there was no real communication between the two. Such diplomatic interaction as occurred was based on mutual misunderstanding.

\section{Andaya's views on treaty and treaty making in historiographic perspective}

Andaya's analysis is as I have pointed out, to a large degree built on Noorduyn, and assumptions supporting his propositions have been shared by more recent authors. Yet, at the end of this section I would like to draw attention to some interpretations that complement or modify Andayas view. Noorduyn for instance draws attention to what he calls "pragmatic opportunism" as a feature of the Bugis political system by the fact that people would back the person considered to manifest the greatest concentration of power as leader. This convention thus represented an additional source of flexibility to the enduring life of treaties to be brought back and forth according to the demands of situation and context. ${ }^{70}$ Christian Pelras on the other hand seems to stress other factors than the sacred conceptualization of cosmos more than Andaya, pointing to that although the ruler ruled by sacred legitimation or divine origin, power was also conceptualized as a contractual relationship between ruler and the people which could be broken if the obligations were not met. ${ }^{11}$ Yet another latent source of flexibility in other words.

Anthony Reid takes this a step further in pointing to the fact that despite the sacred and binding nature of oaths taken before the spirits of the ancestors, there are plenty of examples where these were broken, ${ }^{72}$ which also might be considered a source for flexibility. In a somewhat different

Noorduyn, Jacobus, “The Wajorese merchants' community in Makassar", in: Roger Tol, Kees van Dijk and Greg Acciaioli (eds.), Authority and Entreprise among the Peoples of South Sulawesi, Verhandelingen, KITLV 188, Leiden, KITLV PRESS, 2000, 95-121, 116. 
direction, Reid points out that this was closely related to the readiness of Bugis and Makassarese communities to regulate their affairs by contracts between two parties, each recognising the other's rights. ${ }^{73}$ Because the concept of contract meant trust, there might have been greater respect for mutual contracts than for the authority of kings. ${ }^{74}$ I shall elaborate more on this in subsection 3 below. But before that, a conclusion on Andaya's positions is necessary.

\section{Concluding remarks}

There is little space left for dynamism in Andaya's analysis. Both the Company and the South Sulawesian states acted on their cultural structures well up into the twentieth century. Diplomatic interaction between the two was consequently a continuous process of repeated misunderstandings and conflict.

The picture of seventeenth-century South Sulawesian diplomacy Andaya draws also rests on the basic assumption that even in communication with European outsiders the South Sulawesians applied their traditional logic and approach to state interactions. Likewise, regarding the Company, Andaya's proposition is that it applied its heritage of European diplomatic means and modes without adjusting its expectations to the Asian context. I shall argue that Andaya's static assumptions are historically wrong for both parties. Diplomatic interaction between Makassar and the Company represented a dynamic process. My counterproposition can be illustrated by comparing Andaya's assumptions to those of G. J. Resink's interpretations of seventeenthcentury international law in the Indonesian archipelago and Makassar. I shall go through Resink's points of view, and their implications for Andaya's assumptions, mainly relying on Resink's analysis in The Law of Nations in Early Makassar. ${ }^{75}$ After that I pursue the topic of Makassarese dynamism, briefly introduced above.

Reid, in Tol et al. eds., 2000, 64.

Reid in Tol et al. eds., 2000, 66, 70.

First published as "Volkenrecht in vroeger Makassar", Indonesië, IV, v (March, 1953). My references are to the English version: “The Law of Nations in Early Makassar", in Resink: Indonesia's History between the Myths, (The Hague: W. van Hoeve Publishers, 1968) 


\section{Section 2: Resink's proposition on international law in Makassar and its implications for Andaya's positions}

\section{Introduction}

In The Law of Nations in Early Makassar Resink states that he set himself two goals, firstly to point out parallels between Makassarese notions of international law as compared to the Company's (or Western) notions, and secondly to identify incorporations or adaptations of local elements in the Company's diplomatic practice. Resink's project thus builds on two basic propositions that run contrary to Andaya, namely that there was a kind of international law in Makassar which for all its particular differences was compatible with Western notions of international law. In other words, Resink's assumptions are diametrically opposed to Andayas propositions about the absolute singularity of Makassarese tradition and the incompatibility of Makassarese and Company approaches to diplomatic relations.

I shall first treat Resink's identifications of constitutive institutions in the Makassarese variant of international law and then look at the instances where he singles out particular traits or variances in the Makassarese system. Finally, I shall sum up the instances where he finds integration of Makassarese elements into the Company's mode of diplomacy. My discussion follows a pattern where I first expose Resink's positions and then contrast them to Andaya's proposition with focus on the implications of Resink's view for Andaya's argument. Before I go on to the analysis, it should be mentioned that Resink's argument rests on empirical research at the time of writing. ${ }^{76}$

\section{Parallelisms}

Whereas Andaya points to the difference in meaning and intent in concluding interstate treaties in Europe and South Sulawesi, Resink starts his argument by stating that there was a long-established tradition for concluding diplomatic treaties in South Sulawesi. Examples of such contracts, such as the ulukanaya,

76 In particular A. A. Cense, "Enige aantekeningen over Makassars-Boeginese geschiedschrijving," BKI 107 (1951): 42-60, and V. E. Korn, "Problemen der Makassaars-Boeginese samenleving," BKI 108 (1952): $17-35$. 
a collection of treaties concerning Goa's political relations with its dependencies and other Indonesian states, could for example be regarded as a "Goan Corpus Diplomaticum." 77 As Resink finds no need to qualify the parallelism with respect to differences in meaning and intention in the South Sulawesian treaties, the implication must be that he finds no essential difference between the European and Asian treaties.

The same goes for the perception of boundaries and territories. Pointing to studies by Van Vollenhoven and Korn, Resink claims the existence of "fixed boundaries" for the Makassarese and Buginese principalities "with frontiers sedulously described and delineated ages ago." ${ }^{78}$ As such, a delineation of fixed borders also implies a secular trait shared by people in South Sulawesi and Europe-one that stands in indirect opposition to Andaya's proposition about an absolute contrast between a sacred conceptualisation of statehood in South Sulawesi and a secular conceptual framework in Europe.

Resink finds a similar modern and secular trait in the Makassarese conceptualisation of international law in the field of maritime territorial rights. In the treaty of 1637 with the Company for instance, one finds "recognition of maritime authority in the customary sense of territorial waters." 79 This is but a reflection of the general rule that principalities of southern Sulawesi had such defined "marine belts." ${ }^{80}$ Note that Resink seems to suppose that the clause was included by the initiative of the Makassarese. However, of greater importance in my context is the implication that the Company and Makassar worked within a shared perceptual framework regarding this matter. ${ }^{81}$

Given this background, Resink believes the conflict between Makassar and the Company in the seventeenth century can be seen as a struggle over this kind of maritime authority "in the broader sense." ${ }^{2}$ This proposition is important to note, because it signals quite a different interpretation of the nature of the conflict between the Company and Makassar than Andaya's view that it arose from a structural miscommunication between incompatible parties pursuing different goals. For his part, Resink is quite clear that Makassar and the

Resink, Indonesia's History between the Myths, 41, referring to Cense, "Enige aantekeningen."

Ibid. 43, referring to Vollenhoven and Korn.

79

Ibid. 45. For an analysis of the making of the treaty and its contents, see chapter 4 .

Ibid. referring to Vollenhoven.

81 See chapter 4 for my further corroboration of this point.

82 Resink, Indonesia's History between the Myths, 45. 
company was pursuing the same goals: "Macassar ... with a large-scale transit trade in spices from the Moluccas had no choice but to resist the efforts of the Company to force through treaties banning shipping, transportation and trade on the part of others to promote the monopoly which it desired for itself in the nutmeg and clove trade." ${ }^{83}$ From this perspective, Resink logically comes to view Makassar as a de facto champion of mare liberum $^{84}$, but, contrary to Andaya, assuming that it was acting on secular, commercial motives.

According to Andaya Makassar and the Company were pursuing quite different goals. While the company sought profit, Makassar was interested in prestige. The root of the conflict for Andaya lay in the Makassarese pursuit of the recognition of overlordship in areas where the Company had vested monopoly claims. ${ }^{85}$ So, while for Resink the conflict between the Company and Makassar over the Moluccas was one in which both struggled to get a share of the commercial prize ${ }^{86}$ for Andaya the conflict represented yet another example of misunderstanding due to the incompatibility between the worldviews of Makassar and the Company. The sultan was not a champion of an "open sea"; he was protecting his pursuit of prestige by a proxy argument. His "real" interest lay in the accumulation of prestige, which he could acquire by acting and being recognised as a protector and defender of the faith and overlordship in the Moluccas. Mare liberum was conceived in terms of notions of prestige, not commercial terms in Makassar. ${ }^{87}$

For Andaya, the conflict over the Moluccas between the Company and Makassar sprang from the fact that the one could not have its wishes fulfilled without trespassing on the interests of the other. But they did not have shared interests. The conflict originated in different motivations, namely Makassar's quest for prestige and the Company's for profit. What caused the clash was the fact that control over the Spice Islands served as means to both ends.

For Resink, the conflict between the Company and Makassar over the Moluccas was a conflict over shared interests, as the core of the conflict was that the Company's monopoly claims ran counter to Makassar's economic

\footnotetext{
83 Ibid. 45 .

84 Ibid. 45 .

85 Andaya, The Heritage of Arung Palakka, 46.

86 Reid for one, shares the impression of Makassar as a champion of an open door policy of free trade, Reid $1981,10$.

87 Andaya, The Heritage of Arung Palakka, 46.
} 
interests. Thus, when Makassar applied an open seas argument, it did so to protect its interests as a transit harbour, while the Company tried to protect its monopoly interests by outlawing the transit traffic from the Moluccas on Makassar. In other words, they were both trying to protect their respective commercial interests. The conflict lay in the Makassarese refusal to recognise or adhere to the Company's monopoly claims: "What the Dutch looked upon as Makassarese smuggling ... was perfectly legal trade in the Makassarese view. Hence the (Makassarese) struggle for the mare liberum and against the Company ... was even from the Dutch point of view a struggle against the injustice of the closed seas attempted and perpetrated by the Company in Indonesia." 88 In other words the struggle between Makassar and the Company was primarily a conflict over a common goal: economic resources. ${ }^{89}$ For that reason, the struggle was also fought with a shared rhetoric.

\section{Institutions of international law in Indonesia}

The institution of diplomatic envoys, for one, was one of long standing in Indonesia, ${ }^{90}$ pointing to the existence of a system of diplomatic interaction with similar age-old roots. If this was an institution found in both Indonesia and Europe, there were also specialist institutions in Indonesia primarily meant to facilitate maritime trade. Resink draws special attention to the institution of the sabannara, the Makassarese translation of shahbandar, a local administrative office that can be translated as "harbourmaster" and which was meant to serve the special needs of the maritime states in South East Asia. ${ }^{91}$ The shahbandar was responsible for receiving foreigners and bringing them to the ruler, but there are several instances in which the shahbandars also exercised jurisdictional authority over foreign traders. Resink's point is that states such as Makassar whose income derived largely from maritime trade needed an institution to facilitate and regulate that trade..$^{92}$

\footnotetext{
88 Resink, Indonesia's History between the Myths, 46.

89 Compare "This essentially economic struggle," ibid. 45.

90 Ibid. 48.

91 This is institution is also treated by Cummings, who traces it back to the 1539 s, and notes that the institution was never occupied by high ranking nobles, indicating that it did not have particularly high prestige. See Cummings 2002, 29 and 111 respectively.

92

Ibid. 48-50.
} 
Resink finds similarities between the sabannara or shahbandar and the European medieval institution of consul de la mer, but prefers to regard the shahbandar as a uniquely Indonesian institution because of the shahbandar's function as administrator of international law: "Though all this suggests that the sabannara might in a way be compared to the medieval consul de la mer, it would seem more satisfactory to view him as a quite distinct Indonesian legal functionary who was endowed with both administrative power and regulatory and judiciary authority in the sphere of international law."93

Whatever the particularities of the institutions of the sabannara/shahbandar the point to notice is that the institution and the powers attached to it are indicative of the international nature of the harbour states. Symptomatic of the functionality of the institution is that the Company came to adopt it, under the name of license master. ${ }^{94}$ In both cases, the institution points to a context of (maritime) interaction where a diplomatic repertoire confined to a "landlocked" tradition would be insufficient. Another functional necessity of the maritime interaction system was that it had to make structural space for foreigners or outsiders.

\section{The outsider as a separate category in the Indonesian system of maritime interaction}

Referring to A. A. Cense, Resink states that "Makassarese and Buginese manuscripts time and again contain regulations defining the rights and duties of foreigners, and thus: "in Makassar there must have been a fairly well-defined status for aliens." ${ }^{95}$ In actual fact, Resink holds that Makassar was not only typical, it was an extraordinarily typical example of how a particular defined place for the outsider was designed, as Makassar "saw and drew the lines between the status of aliens and that of subjects more clearly than was customary and necessary at the time." ${ }^{6}$ The mental division between insiders and various outsiders was well entrenched and there was a "vivid awareness of what or who were Makassarese on the one hand and Dutch, English, Danish, Spanish,

\footnotetext{
93 Ibid. 51.

94 Ibid. 50. Referring to Pieter van Dam's use of the term.

95 Ibid. 47.

96 Ibid. 47.
} 
Portuguese, Ternatan, Tidorese, Batchanese and so forth on the other." ${ }^{77}$ This awareness and the legal demarcation between Makassarese subjects and outsiders have serious implications for Andaya's propositions about the nature of Makassarese diplomacy.

As we have seen, Andaya pays no attention to specific regulations for outsiders in Makassar. His argument of incompatibility between the Makassarese and the Company's modes of diplomacy rests on the assumption that the Makassarese applied the same diplomatic approach towards the Company that they would to a neighbouring South Sulawesi state. In other words, Andaya's proposition of incompatibility and structural misunderstanding rests on the assumption that Makassar saw the coming of and contact with the Company as it was approached by a South Sulawesian insider, while in fact there was a special category reserved for the treatment of outsiders. Recognising the fact that the Makassarese had every reason to hold the Company at arm's length, this is hardly convincing. The Company was an obvious candidate to be treated as an "outsider," both by definition, as well as for tactical considerations.

Furthermore, when Resink points to that the Makassarese system contained a separate category particularly designed for the "outsider", it undermines the foundation of Andaya's dichotomy between the Makassarese and Company's system of interaction, because the very existence of such a category raises the possibility of a plurality of regulatory forms. More specifically, Andaya's assumption that Makassar would simply apply endogenous traditions established to handle interstate affairs in South Sulawesi to its dealing with outsiders is not credible. There were alternative modes reserved precisely for such cases, and common sense suggests that Makassarese rulers would have found these far more attractive than treating the Company as a South Sulawesian "insider."

The presence of outsiders in the Makassarese community further necessitated internationally organised administration of justice at the individual level. ${ }^{98}$ Resink finds examples of this in the 1637,1660 , and 1667 Bongaya Treaty. ${ }^{99} \mathrm{We}$ need not go into details here, but besides demonstrating the existence of specific institutions arising from the cosmopolitan nature of Makassar, it is important to note that the Company would fall under this category.

97 Ibid. 47.

98 Ibid. 51.

99 Ibid. 52. 
Besides the identification of both similarities and differences of international law in Makassar and Europe, Resink also points to instances of Company adoption of local institutions and usages. One I have mentioned already, namely the appointing of a license master to meet the function of the shahbandar. Another example to which Resink draws attention is the habit of naming the treaty after the name of place where it was concluded ${ }^{100}$, which is a weaker case, considering that this was a European custom too. But another feature pointed out, namely the gradation of different types of relationships between treaty partners ${ }^{101}$ is particularly interesting when placed alongside Andaya's propositions. Referring to Cense, Resink states that in the Makassarese system, "relationships could range from a "footing of equality" to various degrees of subservience and dependence. ${ }^{102}$ That the Company adopted this system is evident from the Company's subsequent practice of employing the same variety of relationship types in its treaties with other local rulers. ${ }^{103}$

As we have seen, Andaya emphasises that South Sulawesian treaties typically specified the nature of the relationship between the treating parties in the preamble. The fact that naming the type of relationship also made further explication of the reciprocal rights and obligations redundant further distinguished the South Sulawesian tradition from the European. Resink's demonstration of the Company's adoption of certain local treaty elements, however, weakens Andaya's argument about the absolute dichotomy between the "Western and South Sulawesian treaties." If elements from one tradition could be integrated into the other, there must have been some sort of compatibility. Such part-by-part adoption is blocked in Andaya's structural assumptions.

It is important to note the contrast between Resink's and Andaya's views on the possibility of cultural exchange more generally, as they represent diametrically opposite approaches. By proposing an absolute antagonism between the South Sulawesian and Western European modes of conceptualisation, Andaya presupposes an insurmountable barrier to learning by exchange between the two modes. Resink's proposition of compatibility opens the possibility that such cultural exchanges could in fact take place. To which degree the Company adopted local practices I shall not consider here, but I would argue for a

\footnotetext{
100 Referring to Cense, "Enige aantekeningen," and using the Bongaya Treaty as a prime example." Ibid. 42.

101 Ibid. $42-43$.

102 Ibid. 42.

103 Ibid. 42-43.
} 
broadening of Resink's implicit proposition of cultural borrowing in a general direction, and propose that adaptation to Asian contexts was a hallmark of the Company's diplomacy.

\section{Section conclusion}

Resink sums up the aim of his article in the following manner: "that a knowledge of the history of non-European international law thus in this case the specific international law of Indonesia ... can in its turn help to free our knowledge of the history of international law in general from its emphatically European stamp." ${ }^{104}$ This is a statement of a programmatic anti-Eurocentric comparative methodology.

Andaya is also anti-Eurocentric, but from diametrically different comparative assumptions. Resink identifies both similarities and differences between the systems and practices of international law in early modern Europe and Indonesia, and operates from assumptions of compatibility that allow for an analysis of mutual influence. The latter is barred in Andaya's contrasting approach of structural incompatibility. Which point of view encourages the most fruitful interpretation of the nature of the Company's diplomatic method, and which is the more fruitful in analysing the nature of Makassar-Company interaction? I shall restrict myself to summarising how my own propositions look if we take the contrast between Resink's and Andaya's positions as our point of departure.

First, the examples of similarity in Resink's comparison weaken Andaya's propositions of an absolute dichotomy between the Company's and local perceptions of diplomatic interaction. Second, the particular institutions of international law that Resink identifies in the Makassarese system lessen the likelihood that it would have restricted itself to local endogenous models of interaction in its dealings with the Company. Third, the Company's adoption of local elements of international law could probably be regarded as examples of a policy of Company accommodation rooted in a general pragmatic approach.

In the following, I build on all these propositions. There was some compatibility between the Makassarese and the Company's perceptions of

\footnotetext{
104 Resink, Indonesia's History between the Myths, 56.
} 
international law, and thus structural space for meaningful communication between them. Makassar was not confined to one single model as far as its dealings with the Company went. As a harbour state, the Makassarese had developed a system of international law that offered structural space and institutions in which the Company could be categorised as an "outsider" on par with other outsiders. But it was neither the first nor the most important one.

\section{Section 3: Two views on Makassarese dynamism}

In this section I present two views on Makassarese dynamism, mainly represented by William Cummings and Anthony Reid. The former holds that there was dynamism in early modern Makassar, particularly embedded in the coming of writing, whereas the latter also subscribes to that there were dynamics and change, but primarily sees this in conjunction with expansion in trade and cultural contacts. More importantly the two differ in the contents and nature of the dynamics. Whereas as Cummings sees it as a change that gives a new forms and meanings to existing "traditional" structures, Reid interprets the changes he finds as parts of a process towards more "modern" structures. I shall clarify their respective positions, with a particular focus on Reid and the implications his positions on dynamics of modernity has for Andaya's propositions.

Cummings is not alone in countering propositions of societies in the Eastern archipelago as "self-perpetuating systems." Hans Hägerdal for one has argued change and dynamism in Timor, subscribing it to increased income from trade. ${ }^{105}$ Gerrit Knaap has done the same for Ambon, subscribing increasing dynamism to increased outside contacts and the number of people with experience with the outside world. ${ }^{106}$

Cummings singles himself out in that he declares himself in opposition to the all-embracing and exclusive status he thinks Reid gives to commerce as the driving force of historical dynamics. ${ }^{107} \mathrm{He}$ sets out to analyse the beginning of written manuscripts in the beginning $16^{\text {th }}$ century, as the motor of a particular social and cultural change, or as he calls it: "a shift in historical consciousness." ${ }_{108}$

\footnotetext{
105 Hägerdal 2012, 55.

106 Knaap 2004, 12-13.

107 Cummings, 2002, 127.

108 Cummings, 2002, 12.
} 
With the introduction of writing, custom was now no longer perceived as resting with the elders, but in written manuscripts. ${ }^{109}$ Thus "custom" was codified into "culture." ${ }^{110}$ Cultural codification along with an increased strengthening of the social hierarchy and political centralisation were the big processes that were facilitated by literacy. ${ }^{111}$

As one of the changes brought with the transition to literacy was an increased importance put on ancestors or the written past, with it came a new emphasis on genealogies. ${ }^{112} \mathrm{~A}$ curious by-product of this was the creative fabrications of them where parents for instance would put Arung Palakka into their genealogies. ${ }^{113}$

On a more general level the changes that writing brought to Makassarese society were firstly, an enhanced authority to those who possessed written texts, be it genealogies or histories, and a change of view on past and present (by the enhanced weight put on genealogies for instance, and that the past came to be viewed as something that could be possessed (by manuscripts or objects). Put together these changes extended and refined the social hierarchy in a direction that later came to be viewed as "classical." ${ }^{114}$ That proposition is the key point in my context. For, if literacy brought about profound changes in Makassarese mentality, perception and world view, ${ }^{115}$ it was a change that cemented structures that were still "traditional" in the sense that it was looking backwards into a reconstructed past. For Cummings, the Makassarese dynamics lay in the increased emphasis and reconstruction of that past. As already stated, Reid's interpretation of the early modern dynamics in Makassar is that it is "modern", in the sense that it is perceived in perceptions about the future.

\section{Reid on Makassarese dynamism}

Christian Pelras stresses as characteristic of the Bugis their ability in cultural borrowing of novelties from the outside, particularly brought about by external contact and trade which up to the 19th century "produced by a continuous

\footnotetext{
109 Cummings, 2002, 169, 170, 172.

110 Cummings, 2002, 177.

111 Cummings, 2002, 195.

112 Cummings, 2002, 104.

113 Cummings, 2002106.

114 Cummings, 2002, 126.

115 Cummings, 2002, 11.
} 
process of change." ${ }^{116}$ This dynamics by cultural borrowing concerned almost every area of Bugis life - customary law, socio-political rules, customs, rites and creeds. ${ }^{117}$

Reid points to similar dynamic traits, although possibly more restricted to the ruling elite, but nonetheless depicted as a general trait in Makassar from the end of the sixteenth until the second half of the seventeenth centuries. As examples of innovations and changes in this dynamic period Reid mentions that in the wake of an incident with the Dutch in 1615 the then sultan Alauddin and his first minister Matoaya ${ }^{118}$ started to build brick walls for defence purposes. It was done in a European fashion which marked "a sharp break with older Indonesian methods of warfare." ${ }^{119}$ Matoaya also had the forts Ujung Pandag and Pannakkukang built, and there were innovations in the manufacture of cannons and small muskets, as well as technical innovations in shipbuilding. There were also innovations in the minting of gold and lead. ${ }^{120}$ Supporting the picture of an innovative culture and inquisitiveness was that there were translations into Makassarese of technical treatises from Spanish, Portuguese, Turkish, and Malay authorities, as well as map making. ${ }^{121}$ Reid also holds forth that the shift to Islam should be regarded as a (cultural) innovation. ${ }^{122}$

With respect to the population growth in Makassar, the rise is estimated to be from only a few thousands in the 1590s to about 25,000 in 1615 and 100,000 at its peak 1640-1660, and is taken as an overall indication of the seventeenth century's economic growth and dynamism. ${ }^{123}$ On the one hand it is clear that this growth can be considered part of the general growth in maritime Southeast Asia in the early modern period, ${ }^{124}$ the question is how the inventiveness of the Makassarese can be explained. According to Reid it sprang from the nature of the Makassarese leadership at the time, which

\footnotetext{
116 Pelras, 1996, 149.

117 Pelras, 1996, 150.

118 See: section 2, chapter 1.

119 Reid, Anthony, "A great seventeenth century Indonesian family: Matoaya and Pattingalloang of Makassar", Masyarakat Indonesia, 8/1, 1-28, 1981, 11.

120 Reid, 1981, 12.

121 Reid in Tol et al., eds., 2000, 60.

122 Reid, 1981, 13.

123 Reid inTol et al., eds., 2000, 58.

124 See: Reid, Anthony, Southeast Asia in the Age of Commerce, 1450-168o, vol. 2: Expansion and Crisis, New Haven: Yale University Press, 1993.
} 
demonstrated an "unusual aptitude .... for adopting new ideas and technologies." ${ }^{125}$

\section{The nature of late sixteenth and seventeenth-century leadership in Makassar}

As for Matoaya, ruler of Tello and chancellor of Goa 1593-1637, Noorduyn praises his sensible politics as for instance in his non- offensive, conciliatory policy towards Bone during the Islam-wars. ${ }^{126}$ It is also necessary to notice that Sultan Alauddin was both a nephew and pupil of Matoaya. ${ }^{127}$ Reid evaluates both Matoaya and his son Pattingalloang as possessing an extraordinary combination of intellectual eminence and political wisdom. ${ }^{128}$ While a lot of the innovations mentioned above can be ascribed to the initiatives of Matoaya, as for intellectual orientations and cultural openness Pattingalloang deserves some more detailed comments.

\section{Pattingalloang}

Indicative of Pattingalloang's openness and intellectual curiosity is that he was exceptionally fluent in Portuguese and Spanish, and had a library of European books. He also showed an interest in applied mathematics. ${ }^{129}$ In Reid's evaluation it is certain that Pattingalloang's role in Makassar, seen in the light of his interest in European science, mathematics, and astronomy, "influenced the culture of Makassar in this period, and lay behind many of the innovations to which it gave rise." ${ }^{130}$ Also by the VOC there was appreciation of this man of the "Makassarese enlightenment", as Reid calls him. ${ }^{131}$

After Pattingalloang's death in 1654 and with the succession of Sultan Hasanuddin, according to Reid, there was a change of system of government.

\footnotetext{
125 Reid in Tol et al., eds., 2000, 58.

126 Noorduyn, 1955, 98.

127 Pelras, 1996, 135.

128 Reid, 1981, 3.

129 Reid, 1981, 20-21.

130 Reid, 1981, 22. I should also make a reference to Tristan Mostert's contribution: "Ik vertrauwe dat de wereldtbhem naar dien twee polen keert" in Lodewijk Wagenaar (ed): Aan de opverkant: Ontmoetingen in dienst van de VOC en WIC, 1600-1800 (Leiden: 2015), 77-96, who paints a vivid picture of Pattingalloang's quest for knowledge.

131 Reid in Tol et al., eds., 2000, 60. "a man of great knowledge, science and understanding."
} 
Goa and Tello were unable to agree who should be the Chancellor, Hasanuddin himself, or one of two of the sons of Pattingalloang, Karaeng Sumana or Karaeng Karunrung. ${ }^{132}$ In the end Hasanuddin decided to be his own chancellor, which meant the end of the division of Sultan and chancellor in Makassar. ${ }^{133}$ Reid reckons Hasanuddin to be a "weak" character and he marks the beginning of his reign as the start of the demise of Makassarese dynamism. ${ }^{134}$ But returning briefly to the role of the exceptionally able rulers and advisors just discussed, I shall now turn to the structural factors that Reid points to as crucial for explaining Makassarese dynamism during their reigns.

\section{Structural factors}

Besides the luck of quality in the two chancellors, Matoaya and his son Pattingalloang, Reid primarily points to the capacity to attract trade and traders; by providing security of life and property and by offering an open society as structural factors behind Makassarese dynamism. ${ }^{135}$ There were also other structural factors such as the concept of contract as being closely related to a typical pluralistic political assumption, which gave the Bugis and Makassarese communities the readiness to regulate their affairs by contracts between two parties, each recognising the other's rights. ${ }^{136}$ The position and role of the Portuguese may serve as an example in both the general openness and security of property and business transactions.

There is no doubt that the Portuguese in Makassar were the main providers of arms and gunpowder and the main agents of diffusion of Western written books and on such various subjects as fort building, artillery, mathematics, astronomy, geography and cartography, some of which were translated into Makassar and Bugis. ${ }^{137}$ When the Portuguese in Makassar chose to stay on, it seems reasonable not only to contribute this to the security provided for property and business, but also to an environment of religious toleration.

\footnotetext{
132 Reid in Tol et al., eds., 2000, 70-71.

133 Reid, 1981, 26.

134 Reid in Tol et al., eds., 2000, 70.

135 Reid in Tol et al., eds., 2000, 61.

136 Reid in Tol et al., eds., 2000, 64.

137 Pelras, 1996, 141.
} 
After the shift to Islam there was toleration of Portuguese Christian worship, four new places, ${ }^{138}$ as well as the presence of Franciscans, Jesuits and Dominicans. ${ }^{139}$ According to Reid, Makassar stands out as "the most striking example of religious tolerance in a generally tolerant archipelago." ${ }^{40}$ This toleration he proposes could be regarded as an aspect of Makassar's general welcome to foreigner traders. ${ }^{141}$

\section{A seventeenth century cultural shift with "modern" implications?}

Reid's positions on Makassarese dynamism, is that it on the one hand formed part of a pattern of global integration where Southeast Asia as other cultures after 1500 came into continuous contact with each other "with an intensity not previously imagined." ${ }^{142}$ By an unusual luck of able leaders, and wise policies establishing structural conditions promoting trade and technological as well as cultural innovations, a dynamism sprang forth which made the Makassar chronicle read like a "litany of innovations." ${ }^{143}$

Reid clearly indicates that these innovations might be part of a greater shift in mentality, and then in the direction of "modernity" in a broad definition of the term which would include a direction towards a more pragmatic approach to myth and religion. Models taken over from the Dutch, under Pattinggaloang, in the writing of "state diaries", which recorded state events, chronologically, with dates both in the Christian as well as the Islamic form, Reid takes as an example of this. ${ }^{144}$ But the phenomenon was by no means entirely new: The chronicles of Tello and Goa reveal that the authors had no doubt about the concept of progress, states Reid ${ }^{145}$ and goes on to label the nature of the historical writing of Tello and Makassar as an indicator of the open nature of Makassarese society in the seventeenth century: "If one of the key features of

\footnotetext{
138 Reid, $1983,139$.

139 Reid, 1981, 18, and Reid in Tol et al eds., 2000, 60.

140 Reid, 198118.

141 Reid in Tol et al., eds., 2000, 58.

142 Reid: "Early Modernity as Cosmopolis: Some Suggestions from Southeast Asia”, in Sven Trakulhum and Ralph Weber (eds.), Delimiting Modernities - Conceptual

143 Reid, 2015, 135.

144 Reid, 2015, 136.

145 Reid in Tol et al., eds., 2000, 59.
} 
an "Open society" is historical writing concerned to preserve past events rather than to construct a state mythology, to portray the dealings between states rather than asserting the superiority of one of them, to record disasters as well as triumphs, the chronicles of Goa and of Talloq get high marks." ${ }^{146}$

The picture that Reid paints of Makassarese dynamism stands in opposition to the tendencies towards a new and enhanced "traditionalism" portrayed by Cummings. One may thus wonder whether Knaap's criticism that Reid is making it "too macro economically rational" ${ }^{147}$ when describing the motives of Southeast Asian leaders when engaging in war - whether he is not making the same anachronistic misjudgement in describing Makassarese dynamism.

I shall not approach this issue on a general basis, but point by way of example that even if Cummings is right on the general level, Reid's propositions about seventeenth-century Makassarese dynamism are primarily about members of the leadership in a restricted period of time. For all its merits or faults the argument is of vital importance in our context because these were the people that the Company was negotiating and concluding treaties and waging war and concluding peace with. It simply strongly implies that the Makassarese leadership had a certain grip on the motives and modes of operation of their Dutch adversaries.

\section{Section 4: The structure of the argument}

In chapters 1 and 2, I have introduced my topic and presented propositions in the historiography as well as stated my own positions. The remaining chapters are dedicated to an empirical analysis of the Company's diplomatic thinking and practice. Chapter 3 introduces my empirical counter-argument to categorisations of VOC diplomacy as "Eurocentrically dogmatic" by demonstrating that, even in the Republic people were aware that European concepts and standards of diplomacy did not necessarily apply in the charter area. On analysing the respective Generale Instructies sent from the Heeren XVII in the Republic to the High Government in Batavia, with an emphasis on the last and final instruction of 1650 , my conclusion is that not only the latter, but all these

\footnotetext{
146 Reid in Tol et al., eds., 2000, 61.

147 Knaap. Gerrit: "Kora-kora en kruitdamp - De Verenigde Oost-Indische Compagnie in oorlog en vrede in Ambon", in Knaap, Gerrit, and Teitler (eds.) De Verenigde Oost- Indische Compagnie tussen Oorlog en Diplomatie (Leiden: KITLV Uitgeverij, 2002), 257-279. 279.
} 
instructions either imply or openly stress adaptation to local modes and circumstance in a way that defies any categorisation of them as dogmatically Eurocentric. The key message in the Heeren XVII's General instructions to the High Government is one of awareness of local particularities as the basis for the conduct of pragmatic diplomacy. In a brief section on the Directors' particular patriase letters on Makassar I demonstrate that these conform to the general picture.

The encounter between the Company and Makassar in 1637 that ended up with the first treaty between the two forms the topic of chapter 4. Here I refute Andaya's argument of structurally conditioned diplomatic miscommunication between the Company and Makassar. By analysing Van Diemen's report on the encounter and process of treaty making with Sultan Alauddin, I demonstrate that the Company's approach in the negotiations was one of adaptive pragmatism. Not only that, the Makassarese reactions and proposals bear witness to the fact that there was functional communication between the two parties. Although the 1637 encounter was characterised by mutual suspicions and uncertainty, Sultan Alauddin and Van Diemen were in essence playing a diplomatic game by compatible rules, and both seem to have been were well aware of it.

In chapter 5 , I turn to the discussion on policy within the High Government itself. The topic is the disagreement between Governor- General Maetsuyker and Superintendent Arnold de Vlaming in 1655 on whether to take a hard- or a soft stand towards Sultan Hasanuddin. The analysis is primarily based on Maetsuyker's presentation of the reasons for his rejection of De Vlaming's hard-line approach to the Heeren XVII in Maetsuyker's general letter of December $24,1655 .{ }^{148}$

In his defence of the soft approach, Maetsuyker systematically presents De Vlaming's arguments point by point. Ironically, the discussion on the one hand gives us an insight into their disagreement on policy, but although the two men disagreed, they also shared some basic tenets, for example about the goals. The disagreement was over assumptions and means, and was based on diametrically different perceptions of Sultan Hasanuddin's character and plans. Maetsuyker trusted that Hasanuddin had learnt his lesson and would not

\footnotetext{
148 December 24, 1655, in W. Ph. Coolhaas, Generaele Missiven van Gouverneurs- Generaal en Raden aan Heren XVII der Verenigde Oostindische Compagnie, vol. 3, 1655-74 ('s Gravenhage: Nijhoff, 1968), 4-8. (Hereafter GM.)
} 
interfere in the Moluccas anymore, while De Vlaming, distrusting the Sultan, was convinced that he would.

Equally important, the very existence of this disagreement and discussion weakens propositions about the Company as a monolithic body. The fact is that the issue of whether to take a "soft" or a "hard" stand against Makassar was the subject of discussion in Batavia, and that the arguments from both sides were presented to the Heeren XVII, shows that the Company's diplomacy was flexible and reactive rather than dogmatic. Moreover, both sides based their arguments on contextual considerations rather than fixed legal principles.

As for dynamics and trends in the High Government's deliberations on Makassar, there is a decisive break after 1655 away from "soft diplomacy." With the disillusionment after the conclusion of the 1655 treaty there came a growing belief that a lasting contractual order with Makassar could not be established unless it was preceded by a complete military victory. I elaborate on this shift in chapter 6, where I treat the change in policy assumptions from 1656 to 1661 as they can be read from the Generale Missiven in that period. A close reading of the sections on policy towards Makassar reveals how Batavian decisions on diplomacy towards Makassar formed a "learning process" based on experience on the ground. This runs counter to propositions of fixity, whether of a cultural-conceptual or legalist-dogmatist kind. The Company was able to both learn from experience and readjust its approach according to lessons learned. The determining factor in policy decisions and shifts of approach in Batavia lay predominantly in changing assessments of tactical opportunity and other constraints. In other words, policy deliberations in Batavia were based on evaluations of context more than legal text. Flexibility moulded by contextual considerations stand out as a characteristic of the High Government's decisions on policy.

In chapter 7 I pursue the argument about the contextual focus and dynamic nature of the Company's diplomatic approach presented in chapter 6, albeit from a more concrete and specific point of view. Contrasting the treaties of 1637 and 1655 on the one hand and the treaty of August 1660 on the other, I demonstrate how the general learning and adjustment process outlined in chapter 6 is reflected in a move towards a more constructivist perception of "treaty" by the High Government after 1655.

Chapter 8 takes this one step further in that it analyses the construction of Company hegemony treaty in the respective post-1660 treaty texts up to and 
including the Bongaya Treaty of 1667 and the one with Tello in 1668. By situating the treaties analysed in both these chapter in their respective contexts and varying expectations towards the Makassarese, I demonstrate three essential interconnected characteristics of Batavia's treaty making. First, legal thinking and appeals to principles of international law played a limited and very narrowly defined role in all these treaties. Second, the difference between the contracts, both in the selection and contents of the regulations, as well as in the mode of formulating the clauses, can all be explained by variations in the appreciation of the context and changes in the Company's expectations towards Makassar.

Symptomatic of Batavia's devaluation of its trust in the Makassarese after 1655 is that not only was the number of clauses of the 1660 treaty increased significantly, they were far more detailed and specific than they had been previously. This elaboration would reach its acme with the Bongaya Treaty. These traits, including an almost ritually repetitive insistence on the binding nature of the treaty, do not reflect a "legalist obsession" on the part of the Company; they were meant as safeguards against a breach of contract. The contents and form of the 1660 treaty thus reflect a move towards a more realistic and possibly cynical perception of treaty making compared to the High Government's assumptions and beliefs in 1655 .

The difference between the 1660 and 1667 contracts reflects the fact that the latter was drafted in the aftermath of a total military victory for the Company and its allies and the unconditional surrender of the Makassarese. The Bongaya Treaty was part of a treaty complex that included not only Makassar but the other states in South Sulawesi and the outer islands. Together this treaty complex made up a system whereby the Company was hegemon. The 1660 treaty on the other hand was a bilateral one that represented a "middle ground" as far as the Company's political status was concerned.

Speelman's reflections on how to maintain the hegemonic position created by the Bongaya treaty complex, as recorded in his Notitie of $1669,{ }^{149}$ forms the

149 Cornelis Speelman: Notitie dienende voor eenen corten tijt en tot nader last van de Hooge Regeeringe op Batavia, tot naarrigtinge van de Onderkoopman Jan van den Oppijnen, bij provisie gesteldt tot Opperhooft en Commandant in 't Casteel Rotterdam, op Maccasser, en van den Capitain Jan Fransz; als hoofd over de Militie, mitsgaders die van den Raadt, anno 1669. VOC 1276 OB, Inkomen Briefboek Makassar 1671, fols. 684-1007 (Hereafter "Notitie.") I have had immense help by comparing the original source with the typed manuscript undertaken by W. Ph. Coolhaas and Dr. H. J. de Graaf in 194950, now at the KITLV (Nr. H 802). 
topic of chapter 9. The Notitie, some 600 folio pages long, contains both a broad and detailed geographical and political mapping of Sulawesi and the outer islands, as well as detailed instructions on the running of the Company's colonial headquarters, Fort Rotterdam. I shall be concentrating on Speelman's presentation of the challenges of hegemonic rule and his advice on how to meet them as his reflections on these points mainly cover surveys of who is and is not trustworthy and recommended modes of diplomatic action. Chapter 9 constitutes a reconstruction of Speelman's "overseas diplomatic model" with a focus on these aspects of it.

"Reconstruction" is the keyword here, because one of my basic points is that Speelman worked on a case-by-case basis and never presented a general model of overseas diplomacy. His "model of diplomacy" thus must be constructed from his specific advice.

It is also important to note that Speelman's case-based approach was dependent on getting precise and accurate information about local affairs. The Notitie typically abounds with an insistence that good overseas diplomacy depend on obtaining accurate information. This insistence on basing decisions and choice of action on extensive empirical information is one of two factors that stand out as general traits of Speelman's approach towards overseas diplomacy in the Notitie. The other is his reliance on agency and personal diplomacy. Clearly working from, but never elaborating on, the assumption that local diplomacy had a strong personal bias, Speelman's analysis of local power contexts and the tactical space it left for Company influence and control is focused on the personality traits of men who are in, or aspire to, power. The personalised approach may be explained by the overall purpose of preempting the rise of foes and keeping the bonds of alliance with old and new allies in a political environment built on personal charisma and bonds.

Context also played a part in Speelman's political perspective, though it seems to be subsidiary to agency. Chapter 9 consequently has two parts. In the first, I analyse Speelman's thinking regarding the institutional dimension of the hegemonic order, and in the second I look at his recommendations vis-à-vis personal diplomacy. Both sections reveal an "open" and unprejudiced approach towards overseas diplomacy. With ups and downs, and some counter-cases, I still hold that this attitude and approach stands out as a general, but increasingly marked feature of the Company's diplomatic performance towards Makassar between 1637 and 1667 . 


\section{On the primary sources}

The material I use for my reconstruction of the Company's model of overseas diplomacy comprises documents that were produced at various levels of, and served separate functions in, the Company hierarchy. The reconstruction of diplomatic mode as initially devised by the Heeren XVII, the patriase model of overseas diplomacy, which is dealt with in chapter 3 , is primarily based on the General Instructions from the Heeren XVII of 1609, 1613, 1617, 1632, and 1650 , as well as a selection of comments on Makassar in their particular letters to the High Government. ${ }^{150}$ The discussion of the nature of the Company's perceptions about Makassar, and the nature of the communication between Makassar and the Company, analysed in chapter 4, are primarily based on Van Diemen's report on the negotiations in Makassar, June 24- 26, 1637, ${ }^{151}$ and secondarily on the treaty text itself, as compiled by Heeres. ${ }^{152}$ For the discussions over policy towards Makassar and the policy assumptions of the 1655 treaty, I rely mainly on the advice concerning Makassar in the Heeren XVII's General Instructions of 1650 . For the difference of opinion between Maetsuyker and De Vlaming, I rely on Maetsuyker's Generale missive of December 24, $1655 .{ }^{153}$

As for the shift after 1655 from the optimistic view that the Makassarese could be trusted not to interfere in the Moluccas, to the more realistic view that the Makassarese would interfere if not deterred, analysed in chapter 6, I rely mainly on the information on Makassar found in the Generale Missiven of the period 1656-61.

150 "Instructie voor Pieter Both, Gouverneur Generaal en die van den Raad van Indiën," November 14, 1609 ;

“Ordonnancie en Instructie voor den Gouverneur Generaal en den Raden van India," August 22, 1617; "Punten en artikelen, in Forma van Instructie, voor Hendrik Brouwer, Gouverneur en Generaal en de Raden van Indië," March 17, 1632; and "Punten en artikelen in form van Generale Instructie voor den Gouverneur Generaal en de bijvoegde Raden," April 26, 1650, all in Pieter Mijer, Verzameling van instructiën, ordonnanciën en reglementen voor de regering van Nederlandsch Indië, vastgesteld in de jaren 1609, 1617, 1632, 1650, 1807, 1815, 1818, 1827, 1830 en 1836, met de ontwerpen der Staats-commissie van 1803 en historische aanteekeningen (Batavia: Lands-drukkerij, 1848).

151 "Verhaell vant gene d'Heer Generaall van Diemmen wedervaren is zyjne Amboijnesche voijage int weder keeren voor Macassar," June 22-26, 1637, in Dagh-register gehouden int Casteel Batavia vant passerende daer ter plaetse als over geheel Nederlandts-India. Anno 1637, edited by H. T. Colenbrander ('s-Gravenhage: Martinus Nijhoff, 1899), 280-89. (Hereafter, DRB.)

152 "Treaty of peace between the king of Makassar and the noble Gentleman General Governor Antonio van Diemen, June 26, 1637." Corpus Diplomaticum, 1.303-306.

153 December 24, 1655, GM 3.4-8. 
The nature and dynamics of the High Government's treaty making with Makassar in the period 1637 to 1668 in chapters 7 and 8 are based on the texts of the contracts, as compiled by Heeres and Stapel in the Corpus Diplomaticum Neerlando-Indicum. The ninth chapter in which I reconstruct the diplomatic model implicit in Cornelis Speelman's advice for his successors as the Company's leading representative in Makassar is wholly based on his Notitie.

\section{The nature of the primary sources and method}

The sources on which I base my analysis range from the Directors' orders sent from the Republic to the on-the-spot decisions and deliberations on policy in Batavia. The documents span from Instructions from the Heeren XVII to the Company's authorities in Asia, to reports from Company servants in the charter area (octrooigebied) to Batavia. And not the least, my sources include the product of these diplomatic negotiations, the written contracts or treaties themselves.

The sources I use have admittedly all been used before, but not for the same primary purposes, and neither have they been used in the way that I have. I do not intend to use my sources as building blocks in a general reconstruction of interaction. That has been done before. I treat and analyse my relevant documents to find indications about a mode of thinking about diplomatic practice in a cross-cultural setting. Therein lies the originality of this study. The method that follows from this approach is to read these documents closely to see what they may reveal about the Company's diplomatic mind. There is nothing fancy about my method. It is simply based on close reading of meaning and intent in these official documents with the aim to establish characteristic traits and typical dynamics in the Company's assumptions and thinking about its diplomatic practice towards Makassar in the seventeenth century. Using CompanyMakassarese interaction as a case study, it goes by definition that I also intend to say something about the nature of the Company's seventeenth-century overseas diplomacy on a more general level. 


\section{3}

\section{The model of overseas diplomacy in the Heeren XVII's Generale Instructies and the advice on Makassar in the particular letters}

\section{Section 1: Chapter introduction}

\section{Chapter topic}

During the Company's existence, five sets of General Instructions were sent from the Heeren XVII in the Republic to the High Government in the charter area, namely the Generale Patriase Instructies of 1609, 1613, 1617, 1632, and 1650, respectively. ${ }^{1}$ These were meant to serve as general manuals for the Company's operations in Asia. The 1613 Instructions is reprinted in the third volume of Pieter van Dam's Bescryvinge van de Oostindische Compagnie, ${ }^{2}$ and all the others have been preserved and compiled by P. Mijer. ${ }^{3}$

\section{Chapteraim}

All these instructions were primarily concerned with the conduct of trade, but the Company's trade was always intertwined with politico- diplomatic implications. Advice on how to act towards local rulers in the charter area was thus

\footnotetext{
See "On the primary sources", above.

F. W. Stapel (ed.) 's Gravenhage, Matinus Nijhoff, 1943, 544-556.

In: Mijer, Verzameling van instruction, 1848.
} 
also offered in the instructions. The General Instructions may therefore serve as a source of the Directors' ideas about the politico-diplomatic dimension of trade. My aim in this chapter is to reconstruct how the Directors' thinking on overseas diplomacy was reflected in their explicit advice and implicit assumptions in their comments on how the High Government should act when dealing with respective rulers and states in Asia. As for the Directors' comments on Makassar in their particular letters, I have primarily checked these to see to what degree they conform to the thinking in the general instructions.

\section{Chapter propositions}

Already in 1965, Charles Boxer noted of the 1650 Instructions that in the areas where the Company held no territorial rights or privileges by exclusive treaty, which comprised by far the largest part of its area of operation, the Company was instructed to proceed in a conciliatory and accommodating manner. ${ }^{4}$ In this chapter I propose that pragmatic adjustment to local conditions and context constituted the basic approach not only in the advice on diplomacy in the 1650 Instructions, but was a recurring feature in all the instructions from 1609 to 1650 . Not only that, I argue that the imperative to act pragmatically and accommodate grew proportionally with the expansion of the Company's trade area. Implicit in this proposition of pragmatism is a relative devaluation of the role of international law in the Company's overseas diplomacy.

I argue that the Directors accorded a restricted and specific role of not only international law but also European legal concepts in their thinking and advice on overseas diplomacy. Legal theory was reserved as rules of conduct or legitimising devices in two specific areas: Relations with other Europeans, and legitimation of the Company's position as a territorial sovereign and exclusive privileged party. Elsewhere, one had to improvise without being legally compromised. The General Instructions consistently advocate a flexible and accommodating approach to overseas diplomacy based on an assumption that we now would label "cultural relativism."

Pragmatism goes together with dynamics. The Directors' "model" of overseas diplomacy became increasingly insistent on the need for an open, flexible approach. Conversely, the stress on the need to adhere to principles of international law 
became more and more restricted. This tendency seems to have been proportional to the expansion of the Company's area of operations, and thus invites the proposition that even in the Netherlands, views of overseas diplomacy reflected a learning process in which experience rather than legal theory explained the dynamics.

\section{Two additional comments}

Before I go on to present the structure of my argument, I would like to comment on two points of criticism that were raised during my promotion.

\section{A rebuttal to my critics about my interpretation of the role of international law in the Company's diplomacy}

In conjunction with my defense it was argued that the VOC acted as a machtstaat in the Charter area, and that its empire in Asia was in fact an empire of law. The argument ran, in other words, that international law played a greater role than I was willing to admit. Neither at the time was I, nor am I as of today, willing to concede this point, or to moderate my propositions, at least not without qualifications.

The validity of the proposition in which I underplayed the role of international law in the Company's dealings with its local Asian partners all depends on what is meant by the concept "international law". If by it we understand a system of bi- or multinational agreements or treaties between two parties of a state nature, the VOC's trade in Asia was certainly based on it, and on no point has my intention been to reject such a proposition.

The proposition I reject is a proposition of the nature of the body of the VOC treaty or contract practice with Asian counterparts, holding that it was based on particularly European principles of international law in a subtle way to make it generally unintelligible to the Company's Asian partners. It is this interpretation of the Company's use of "international law" as legally subtle and its propositions of incommensurability that I argue against. My argument about the pragmatic approach of the Company as well as my proposition about the functional understanding between the Company and the Makassarese rest on the propositions that the Company's diplomatic practice, including its treaty-making, was pragmatically adapted to local circumstance, which in its turn made reciprocal understanding possible. 


\section{The Role of Islam in Makassarese political thinking}

Another point of criticism that was raised was that I underrated the influence of Islam in the political thinking of the Makassarese elite. The numerous appeals made to Islam by the Makassarese in the negotiations with the Company and the references to Islam in the contracts to support claims by the former could point to this. However, religion and politics were difficult to disentangle in seventeenth century maritime Islam. ${ }^{5}$ There is thus reason to claim that the Makassarese references to Islam equally probably sprang from concerns of power and prestige as from a genuinely religious mental matrix. In other words, the Makassarese religious claims could be understood as a political message, and not exclusively as manifestations of a metaphysical or religious mentality or worldview. I thus propose that there was a secular, political dimension to the religious appeal by the Makassarese which constituted a shared ground for understanding between the Sultanate and the Company. My point is that the religious dimension in the thinking of the Makassarese did not block such understanding and meaningful communication.

\section{Plan of exposition and analysis}

My analysis is split in two main parts. In the first part of the chapter I give an overview of context, general concerns, and the relative position of diplomacy in each of the General Instructions. In the second part, I conduct a more detailed textual analysis of the advice on overseas diplomacy in the 1650 Instructions, which ends up by pointing to continuities and changes as compared to prior ones. I have also added a brief section on the Directors' comments on relations with Makassar in their particular letters to the High Government. I conclude by summarising the nature and dynamics in the Directors' advice on diplomacy, ending up in a clarification of to what extent and under which conditions we may legitimately speak of a "diplomatic model" in the General Instructions.

Finally, I discuss whether it is possible to reconstruct an "ideological superstructure" by which the Company's commercial activity was legitimised by the non-commercial values of the Directors. Affirming this, I give some tentative

5 Anthony Reid, "Islamization and Christianization in Sou theast Asia: The Critical Phase, 1550-1650", in Reid (ed.), Southeast Asia in the Early Modern Era: Trade, Power, and Belief (New York: Cornell University Press, 1993), 173. 
characteristics of the nature of this ideological superstructure and its implications for the conduct of diplomacy.

As for my selection of examples of diplomatic interaction in the General Instructions, the Banda Islands and Ambon, as conquered Company possessions, fall outside diplomacy proper. The diplomatic interaction with other European parties could be viewed as "inter- European practice and parlour" brought overseas, and thus also falls outside the bounds "cross-cultural diplomacy" proper. I shall, therefore only briefly account for the advice given with respect to the Moluccas and relations with European enemies and rivals, and concentrate the analysis on the Directors' advice concerning the interaction with independent Asian rulers. Regarding the comments and advice on Makassar in the particular patriase letters, I have placed these at the end of the chapter.

\section{Method and issues}

As for method, particularly in the textual analysis of the Instructions, I mainly apply close reading: What was the Directors' meaning and intention in saying what they did - or did not say - regarding diplomatic interaction with Asian princes and rulers? From what assumptions about overseas diplomacy did these utterances spring?

\section{Section 2: The respective General Instructions 1609-50, and diplomacy's role in them}

\section{The 1609 Instructions}

The General Instructions of 1609 were written the same year that Habsburg Spain and the Dutch Republic signed the Twelve Years' Truce. The final agreement on the Dutch trade in Asia in the Twelve Years' Truce was that the Dutch were allowed to trade anywhere outside the domains of the united SpanishPortuguese crown. In the Dutch Republic, however, there was little faith that the Spanish would honour this agreement. Besides, the agreement was not to become known in the charter area until one year after its original signing. In short, the 1609 General Instructions, although written at the outset of an armistice, were conceived with an eye to a condition of war with the Iberian powers. ${ }^{6}$ The situation during the Twelve Years' truce has been called "an

6 Mijer, Verzameling van Instructiën, viii. 
armed peace in Europe, and endemic conflict in Asia,"' Another significant contextual factor should be mentioned: By 1609, the Company had not yet established an administrative bridgehead, a "general rendezvous" for Dutch merchants comparable to Portuguese Goa in the charter area.

Seen in terms of the Company's internal development, the historical importance of the 1609 Generale Patriase Instructies is that they laid down the administrative structure that was to last throughout the Company's existence. Whereas before 1609 the final responsibility had lain with the admirals of the respective fleets, the 1609 Instructions introduced the institutions of the governor-general and the Council of the Indies. ${ }^{8}$ As far as the Directors' handling of the topic of diplomacy in the 1609 Instructions was concerned, it can be split in two: Advice on how to handle European enemies and rivals, and advice on how to handle relations with Asian rulers. Neither of the two was given a separate heading, nor was "diplomacy" as such.

\section{Issues, concerns, and diplomacy in the 1609 Instructions}

The General Instructions of 1609 comprised forty-two articles in all. Articles 1 through 7 laid down the institutional structure and procedures for the administration of the Company in Asia. Articles 8-10 come the closest to offering general advice on diplomacy, covering both relations with local kings and princes as well as with the Portuguese. Article 8 introduces a section of advice on various specific issues; whereas article 9 deals with measures to be taken in Banten, then the centre of the VOC's activities in Asia. Tellingly the emphasis is on information gathering, repeated in article 10 which calls for the pursuit of information on local affairs in general and the situation of the Portuguese in particular. ${ }^{9}$ Articles 8-10 could be regarded as an introductory section to the main body of advice on managing affairs in the places that the VOC operated in the charter area. The topical consistency is, however, interrupted by three articles concerning the nature of the "general rendezvous" and the role of "predikanten," 10 and a longer section on private trade and the correct keeping of books. ${ }^{11}$ The latter is succeeded by a section comprising

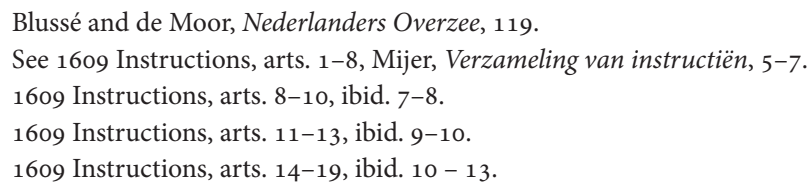


articles 22-37, ${ }^{12}$ which, except for two articles that give instructions on how to behave towards the Portuguese, ${ }^{13}$ are all devoted to specific advice on various places of operation. This section thus comprises by far the lengthiest part of the 1609 Instructions, as it would in the later ones. The focus of the final four articles turns to the running of the factory in Banten. ${ }^{14}$

Although the successive General Instructions after 1609 were to become increasingly encompassing and more structured, a general pattern of organisation is visible already in those of 1609 , namely in the general division between matters of internal administration and order, and particular advice on respective places of operation. The section on particular places of trade always remained the largest, and although we find articles that include comments on overseas diplomacy in general, most of the advice on diplomacy is found in the respective sections on particular places of trade.

Recommendations for dealing with the Portuguese are a recurrent subject. In the 1609 Instructions the subject is treated in separate articles, ${ }^{15}$ but, more often than not, the subject of the Portuguese is treated in conjunction with the Moluccas or other areas of contest between the Company and the Portuguese. In none of the Instructions is diplomatic performance as such accorded a separate section. If the advice on diplomacy in this sense bears a casuistic imprint, the Directors also give clear note, that as for actual performance in diplomacy with local kings and princes, as in the case of trade, it must be up to the High Government to take the final decision. Thus reads, for instance, the message in article 8 , which makes the topical bridge between the section on the administration of the Company's headquarters and the section on particular places of operation: "Regarding how you choose to handle other matters (i.e. other than internal administration) government, trade, and alliances with the Kings and Potentates in Asia, we cannot give you any standing instructions, but only advise, instruct, and partly command as follows." 16

\footnotetext{
121609 Instructions, arts. 22-37, ibid. 13-19.

131609 Instructions, arts. $28-29$, ibid. 16.

141609 Instructions, arts. 38-42, ibid. 19-21.

15 The 1609 Instructions marks an exception here, which must be explained by the particularity of the 1609 context.

16 "Aangaande hoe gij $U$ in andere zaken, de regering, commercie, trafique, mitsgaders de alliantiën met de Koningen en Pottentaten van Indië betreffende, zult hebben te gedragen, daaop kunnen wij U geene faste ordre stellen, maar alleen raadgeven, instrueren ok eensdeel ordonneren als volgt." 1609 Instructions, ibid. 7. For the same contents, see art. 21, ibid. 13.
} 
When the Directors proclaimed not to be in the position to offer specific advice on how to behave towards independent Asian rulers it was most likely because of a felt lack of information. Pointing in that direction is that they consistently stressed the need to gather information about local rulers and their external relations, particularly with the Portuguese. ${ }^{17}$ In this respect the Directors' approach towards independent Asian rulers could be seen as "overseas diplomacy in the making." If fragmentary and lacking in specificity, one permanent feature was established: Diplomatic performance had to be based on optimum knowledge of local goings-on.

\section{The 1613 Instructions Context and general contents}

Much of what applied to the 1609 instructions applied to the 1613 instructions, too. In the negotiations which ended in the twelve years armistice between the Republic and the Iberian powers the Directors had both been pressing for the conclusion of as many treaties of alliance with Asian princes as possible, as well as plans for a consolidation of the Company's structure in the Charter area. ${ }^{18}$ The concerns for internal administrative consolidation is reflected in the 1613 Instructions for instance in the relative number of articles related to the internal administration of the Company, which comes close to two thirds of the total (22 out of 36 articles). Elsewise explicit concerns about forging alliances with Asian princes, implicitly also evident in the encouragement to gather information about local political affairs to that purpose, and lastly instructions to stand firm against the Iberian powers are main topics in the 1613 Instructions that all fall in line with the Directors overreaching aims in the first years after 1609.

\section{General presentation of the contents in the 1613 Instructions}

The 1613 Instructions comprise thirty-six numbered articles, ${ }^{19}$ where the first article lay down rules for the constitution of the Council of the Indies, and the

17 See particularly arts. 9 and 10, ibid. 7-9, see below for textual analysis.

18 J. van Goor: De Nederlandse Koloniën: Geschiedenis van de Nederlandse expansie, 1600-1975, Sdu Uitgevers, (1994) 1997, 46.

19 All the references to the General Instructions of 1613 are to the reprint of it in: F. W. Stapel (ed.): Pieter van Dam: Beschryvinge van de Oostindische Compagnie, Deerde boek, 'S-Gravenhaage, 1943, 544-56. From now on: Stapel (ed.), 1943. 
final one simply declares the completion of the Instructions. The remaining thirty-four articles concern various topics as the authority of the governorgeneral and the Council, to the maintenance of the Company's ships. I shall briefly point out the issues and concerns in the respective articles before I go on to analyse comments made on diplomacy in the text more specifically.

The first article lays down the rules for the constitution of the Council of the Indies (note: 545 ) ${ }^{20}$ whereas article. 2 establishes the authority of the governorgeneral and Council who are free to appoint the personnel, i.e. commanders, captains and soldiers at the respective forts. Article 3 concerns the administration of internal justice, whereas article 4 regulates the handling of fines and confiscations. ${ }^{21}$ Articles 5 and 6 concerns respectively, the oath of loyalty to be sworn by all official ${ }^{22}$ and arrangements to be made when Company officials, governors etc., would come visiting where the governor-general might reside, or vice versa when the governor-general visited such authorities at their place of residence, ${ }^{23}$ whereas article 7 returns briefly to the administration of internal justice.

After having thus delimited various aspects of the Company's internal organisation in Asia in the first seven articles, article 8 demonstrates the great space of authority placed in the hands of the governor-general and Council by the Directors, in that as for the issues to be treated in the rest of the Instructions, be they about other items of internal government, trade and diplomatic relations with kings or potentates in Asia, the Directors did not consider themselves in a state to give general orders, but would offer advice in the specific, ${ }^{24}$ Article 9 instructs the governor-general and Council to obtain as updated and comprehensive information as possible on the state of affairs, and particularly the performance of the personnel in the Company's service at respective other factories, outside Banten, ${ }^{25}$ and thus concerns the relationship between the governor-general and Council in Banten and the other factories.

The conduct of commerce and diplomatic dealings with Asian princes in general is mentioned in article 8 (546), as topics on which, as we saw above, the

\footnotetext{
20 Stapel (ed.), 1943, 544-45.

21 Stapel (ed.), 1943, 545.

22 Stapel (ed.), 1943, 545-46.

23 Stapel (ed.), 1943, 546.

24 geen vaste ordre stellen, maar alleen raet geven, instrueren, oock eensdeel ordonneren als volght, Stapel (ed.), $1943,546$.

25 Stapel (ed.), 1943, 546.
} 
Directors considered themselves not to be able to offer general advice. Still, in article 10, diplomacy with the Asian rulers with whom the Company did trade is presented as a topic on its own, although not entirely, as the Asian princes' relations with the Portuguese and thus the Company-Portuguese is the dominant topic. I shall treat both these aspects of instructions on the Company's diplomacy in more detail below.

To continue listing the content of the articles, article 11 covers the internal, administrative structure in a narrower perspective as it deals with the issue of where the Council should make its headquarters, ${ }^{26}$ whereas article 12 concerns the internal running and coordination of the Company's business, with instructions that when where to establish the headquarters has been decided, copies of the letters from the Directors in Patria should be sent to all the other Company factories in the Charter area. ${ }^{27}$ Article 13 treats another internal aspect of the Company's settlement, namely where to post the respective schoolmasters and preachers sent over. ${ }^{28}$ A quite different matter, the overseeing of the respective factories, is the issue of articles no 14 and 15, where a request to make an inventory of all the factory's assets, and a general accounting book, is given with specifics in detail. ${ }^{29}$ Article 16 again deals with practical matters, but of a different nature, namely the loading and arrangements for placing the goods on the return fleet and how to avoid damages. ${ }^{30}$

In article 17 the Directors ask to be informed about the state of the Company's ships and the eventual need for more ships in Asia, which is followed up by repeating the ban on private trade and sanctions for those breaking it in article $18 .^{31}$ The following article is about proper maintenance of the ships, which is followed up by an article on a quite different subject, as it gives instructions on how to go about trade, and also contains a paragraph regarding boosting morale and dedication to the Company's cause. ${ }^{32}$

Article 21 will be analysed in more detail below as it exclusively and explicitly gives advice on how the Company should act towards Asian princes and thus on

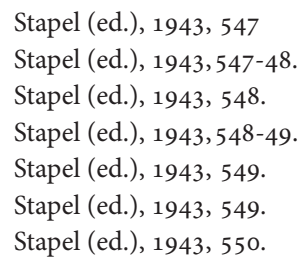


the mode of the Company's overseas diplomacy. The same goes for article 22 as it, in addition to dealing with the relations with Banten and complaints about the high tariffs demanded by the rulers of the Sultanate, also expresses concerns about what this harassment might do to the prestige and standing of the Company and thus indirectly comments on overseas diplomacy.

Advice on the diplomatic approach with respect to specific places and in conjunction with the approach of trade is also given in article 23, whereas the treatment of trade with China, in article 24 , is solely focused on the possibilities of trade and trade relations. ${ }^{33}$

Article 25 is another article that concerns a purely practical topic, namely an instruction to unload and fit out for return the ships coming in from Patria as quickly as possible because of the wear and tear on both ships and equipment when in Asian waters. ${ }^{34}$ The following article, article 26, is again about diplomacy, but not with Asian princes, as it returns to relations with the Portuguese and Spaniards. I shall treat this and all the other articles concerned with diplomacy in a separate section on diplomacy below.

Articles 27 and 28 establish the unrestricted authority of the governorgeneral and Council, ${ }^{35}$ which is logically followed up in article 29 by the requirement that as the Governor-General Reynst had sworn to uphold the regulations in the Instructions before leaving Patria, the members of the Council, not yet having done so, should do likewise on arrival in Asia. ${ }^{36}$ Articles 30 and 31 concern the reorganisation of the sailings for trade with Ambon and Banda, as well as China, ${ }^{37}$ whereas article 32 gives encouragements about the prospects for trade in sandalwood in Timor. ${ }^{38}$

Article 33 concerns an incident of the murder of a Company servant in Surat and how the Company should respond, but as this topic leads to reflections that carry advice on the mode of diplomacy, I shall analyse this aspect and article 33 in conjunction with the other articles which do the same.

In articles nos 34 and 35, the focus is again on internal issues as these articles provide instructions on the succession procedure in case of the death of the

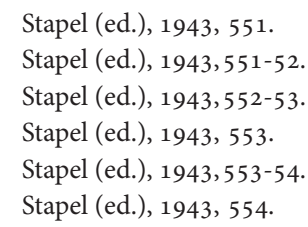


Governor-General Reynst, and practicalities concerning provisions for former members of the Council. ${ }^{39}$

\section{On diplomacy in the 1613 Instructions}

From the overview of topics given in the above paragraph, it could be said that as for relative volume, diplomacy plays a secondary role compared to the matters concerning the running and consolidation of the Company's presence in the archipelago. But still there are some features in the treatment of diplomacy in the 1613 Instructions well worth commenting upon.

In chronological order, diplomacy, whether it is with Asian princes or the Portuguese or the two viewed together, appears in the 1613 Instructions in articles $8,10,21,22,23,26$ and 33. I shall first treat them in chronological order, and then see whether some general traits can be drawn from the particular advice given. Still, to begin with, I would like to point out that the bundle of advice on diplomacy that we do find is not grouped in a separate section of the Instructions, and as often as not, it crops up as afterthoughts on other subjects, instead of being treated as a separate subject.

\section{Article 8}

The first time the topic of diplomatic dealings with Asian princes in the general is mentioned is in article 8 , but there is little else to remark on it than that it juxtapositions trade and diplomacy. ${ }^{40}$

\section{Article 10}

Article 10 on the other hand is more specific in that it requires the obtaining of precise information about the standing and attitude towards the Company of all the princes and peoples that the Company had dealings with in all quarters of the Company's area of operation. ${ }^{41}$ In addition one should also in particular

\footnotetext{
39 Stapel (ed.), 1943, 554-55

40 Compare the formulation: Aangaende hoe ghy in alle andere saken en regieringe, de commercie en traffique misgaders de alliantiën met de coningen en potentaten van Indiën, sult hebben te gedragen. . Stapel (ed.) $1943,546$.

41 Pertinentelijck informeren op de genegentheden, affection ende gunsten van alle ende iegelycke koningen, natiën, ende volkeren van de gantsche quartieren van India. Stapel (ed.) 1943, 547.
} 
determine the position of these local princes and rulers towards the Portuguese, currently, as well as before the coming of the Dutch.

In this connection, international law is brought into the picture in that one is asked to find out who were friends and who were enemies of the Portuguese, and in particular to clarify the legal standing of the Portuguese in relation to their Asian friends. ${ }^{42}$ An imperative to access and communicate information to the Directors regarding trade relations as well as the judicial standing of the Company with Asian princes and rulers likewise required this for the Company's Asian contacts. ${ }^{43}$

Overseas diplomacy is the implicit topic of article 10, in the request to gather information about the attitude of local princes towards the Company and the Portuguese, but it must be added that possibly the issue is understood primarily in conjunction with the Company's relationship with the Portuguese. One trait is worth noticing regarding the relative weight put on the legal side of the matter. I am inclined to argue that getting to know what the legal standing of the Portuguese was with Asian princes, must be interpreted as a survey of the possibilities for the Company to make their own alliances and block the Portuguese. Anyway, in the next article where diplomacy is treated, article 21, international law is given a more universal quality.

\section{Article 21}

Article 21 starts by emphasising the importance of maintaining steady correspondence with Asian princes as a necessary support for keeping up and expanding trade. ${ }^{4}$ "Correspondence" in this context should be understood as the exchange of diplomatic letters. The Directors also have some advice as to how to go about this task. One must proceed wisely with care and discretion (wijsselijck en gantsch discretelijck) so as to maintain good relations, and must pay close attention to who might be considered as potential friends as well as foes. ${ }^{45}$ After having laid down

42 wel examinerende wie vrienden of vyanden mette Portuguesen sijn, omme wat redenen ende op wat consideratie van state alle 't selve gegrondet en gevestight is. Stapel (ed.), 1943, 547.

43 Men overal goede intelligentie magh hebben, ende sooveel mogelijck is te vermeerderen; te oordelen en wetenen wat state des Compagnies saecken staan, op wat pointen van state, alsmede van trafique en handel deselve rusten Stapel (ed.), 1943, 547.

44 alle goede correspondentie, met de koningen van Indiën ...een groot deel van de conservatie van den Indischen handel voor ons en onse nakomelingen gelegen is. Stapel (ed.) 1943, 550. wel overleggende wie... uwe vrienden ofte vyanden behoeven of behoren te sijn. Stapel (ed.) 1943, 550-51. 
these rules, the Directors again stress international law as the basis for the considerations on relations and treaties..$^{46}$ The actual treaties, be they of a political or commercial nature, must however also be concluded with an eye to the glory of God, the welfare of the Republic and the Company's best, the article concludes ${ }^{47}$ Possibly at a risk of exaggerating, the juxtaposition still leads to the thought that international law was regarded as an instrument which furthered both the heavenly and earthly goals of the Company.

\section{Article 22}

As mentioned above, article 22 deals at the outset with complaints about the ruler of Banten imposing new and too high tariffs and tolls on the Company. But concerns are voiced in conjunction with these complaints about the negative effects of these actions. They might lead to a loss of the Company's prestige with other rulers. The Bantenese action was thus not only insulting but could result in serious loss for the Company. ${ }^{48}$ The remedy offered is too keep up good appearances, while at the same time gather information, and if possible, apply countermeasures secretly. ${ }^{49}$ The comments on diplomacy in article 22 demonstrate the secretive side of diplomacy, beneath the legal and formal level.

\section{Article 23}

Article 23 says nothing about the conduct of diplomacy, but encourages keeping or establishing friendly relations with, engaging in trade with, and establishing factories in Johor, Patani, and other places. The instruction is formulated generally to "maintain and establish new alliances of friendship and trade and establish factories wherever possible, ${ }^{50}$ with the additional instruction that this

46 op dat stuck en die overlegginge uwe consideratie in materie van state gegrondet hebbende...Stapel (ed.) $1943,551$.

47 daarna alle alliantiën en verbonden, soo op 't stuck van materie van state, als van proffitelycke traffique met deselve maeckende, ... tot Godes eere, der landen welvaart en des Compagnies profijt gevordert. Stapel (ed.) $1943,551$.

niet alleen schadelijck, maar oock schandelijck tot kleynaghtinge van onse natie, 't welck by alle andere koningen een quade consequentie soude mogen causeren en ons schade, schande en groot nadeel mogen gedyen. Stapel (ed.) 1943, 551.

moet men haar voor onse uyterlycke beeste en erste vrienden houden, waartegens soovel met contrapractycquen en secrete inteeligentiën gearbeyt worden als mogelijck is sonder noghtans de uytterlycke vreede en rulers of vrientschap eeninghsints te breecken of te alteren, Stapel (ed.) 1943, 551. 
be done according to an evaluation of what would serve the Company best. The article does not say anything about the mode of diplomacy; once again it primarily demonstrates the intertwining of diplomacy with trade.

\section{Article 26}

The subject of article 26 is the relations with the Iberian powers and thus strictly speaking it falls outside of my field, as it does not say anything about Asian rulers. Suffice it therefore to say that here the Directors warn that Portugal and Spain certainly will try to harass the Company, which on its side should seek to deter the Iberians in every possible way. However, if the Portuguese and Spaniards should forget and [breach treaties?] then reparations must be sought. ${ }^{51}$

\section{Article 33}

Article 33 represents an example where the article starts by commenting on a concrete-specific case and then evolves into more general advice, in this case on diplomacy. This issue at the outset is retaliation against Surat because of an incident including the murder of a Company servant there. The instruction is to retaliate by any means possible..$^{52}$ But, a diplomatic concern is added as a necessary precondition: One must retaliate in such a manner so as not to provoke Company-friendly Asian rulers..$^{53}$

To my mind, the latter modification sums up the essence of the advice on diplomacy in the 1613 Instructions. The Company should approach Asian rulers with the aim to increase its influence and trade, and should do so by relying on treaties according to international law. But this may also turn to violence, as seen in the instructions with respect to the Iberian powers as well as in the instruction on retaliation against Surat. Still, above all, as is implicit in the emphasis put on acquiring information on local affairs and political relations, and as explicitly stated as concerns in article 22 on Banten and no 33 on Surat, the primary function of diplomacy remained to establish friendly

\footnotetext{
51 met alle mogelycke middlen soecken te weren, Stapel (ed.) 1943, 552.

52 sult pogen by alle mogelycke wegen sooveel schepen, goederen en personen van Suratte onder uw gewelt te krygen als immermeer mogelijck wesen sal. Stapel (ed.) 1943, 554.

53 sonder alteratie van onse gunstige koningen en volckeren van Indiën. Stapel (ed.) 1943, 554.
} 
relations and possibly alliances to facilitate the conduct of trade. Knowledge of local affairs and knowledge of how not to provoke, which was the same as to say knowledge of local manners, were essential constituents in this part of the package.

\section{The 1617 Instructions}

Mijer characterises the 1617 Instructions as more encompassing, more determined in tone, and more structured in the ordering of issues than the preceding ones. ${ }^{54}$ It is also significant that the 1617 Instructions were confirmed and included in both the 1632 and 1650 Instructions. ${ }^{55}$

Besides the obligatory section on particular places of operations, the 1617 Instructions covered a number of topics such as administration of internal justice, the promotion of the Christian creed, conditions for allowing private trade, as well as the promotion of settler-colonisation by free burghers. ${ }^{56}$ The Moluccas was the pressing the issue as far as the Company's external challenges were concerned. In 1615, Governor- General Reynst had decided to settle the score with the Portuguese by conquest, but the expedition under his personal command failed. It was left to Jan Pieterszoon Coen to complete the task. Appointed bookkeeper-general in Banten by Pieter Both in 1613, Coen wrote several letters to the Heeren XVII offering advice on the Company's strategy before he was named governor-general in 1619. The most famous is his Discourse aen de Edele Heeren Bewindhebberen, toucherende den Nederlandsche Indischen Staet (Memoranda to the honourable Directors concerning the state of affairs in the Netherland's Indies) of 1614, in which he advocates a decisive stand and firm action against both European rivals and local rulers who were undermining the Company's monopoly.57 The issues that Coen raised were included in the 1617 Instructions, but the policy recommended against intrusion by rival Europeans and the measures to be taken against local breaches of monopoly agreements were less militant. ${ }^{58}$

\footnotetext{
54 Ibid. Inleiding p. ix.

55 Ibid. Inleiding, $\mathrm{p}$ ix.

56 Stapel, Geschiedenis van Nederlandsch Indië, 3.123.

57 Stapel, Geschiedenis van Nederlansch Indië, 118, 121.

58 Compare particularly arts. 35 and 45, Mijer, Verzameling van instructiën, 1617 Instructions, 34 and 37 respectively.
} 


\section{Hierarchy of concerns by structure of exposition}

The 1617 Instructions comprised eighty articles, almost double those of the 1609 Instructions, and well over double of the Instructions of 1613. The subjects can be grouped into issues in the following order: Articles 1 through 6 covered the administrative structure of the factory in Banten, including the order of succession in case of the death of the governor- general, the enlargement of the Council of the Indies from five to nine members, ${ }^{59}$ and the distribution of administrative tasks among the councillors. ${ }^{60}$ Articles 7-34 concerned the organisational structure and running of the Company's operations in the charter area, covering both political and commercial issues, as well as instructions about "education" and missionary work in the Moluccas. ${ }^{61}$

Articles 35-44 covered miscellaneous topics such as how to handle third-party intrusion into the Company's monopoly possessions, ${ }^{62}$ instructions for the returnfleet, ${ }^{63}$ and regulations for private trade. ${ }^{64}$ Articles $45-47$ started with the general recommendation to stick to peaceful relations and avoid war with Asian rulers. ${ }^{65}$ This obviously has diplomatic implications, but it is succeeded by the issue of eliminating or reducing tolls paid in Banten and elsewhere, ${ }^{66}$ how to proceed in expanding trade with China, ${ }^{67}$ and the issue of military provisions for the fort of Ambon. ${ }^{68}$ The relations with Banten and China required negotiations and diplomacy. In the case of Banten, the High Government was instructed to avoid any cause for war. ${ }^{69}$ Regarding China, the instructions counselled conducting trade in such a way that relations might improve..$^{70}$ One may see articles $45-47$ as a body of diplomatic advice concerning interactions with independent Asian rulers; but if so, the general message and particular advice offer little more guidance than to avoid war. War was also the implicit issue in the next seven articles $^{71}$ concerning

\footnotetext{
591617 Instructions, arts. 1 and 3, ibid. 25-26.

601617 Instructions, art. 4, 1617, ibid. 26.

611617 Instructions, art. 34 , ibid. 34 .

621617 Instructions, art. 35 , ibid. 34 .

631617 Instructions, arts. 36-40, ibid. 36.

641617 Instructions, arts. 40-44, 1609, ibid. 37.

651617 Instructions, art. 45, 1617, ibid. 37.

661617 Instructions, art. 46, 1617, ibid. 37.

671617 Instructions, art. 47 , ibid. 37.

681617 Instructions, art. 48 , ibid. 37.

691617 Instructions, art. 46, ibid. 37.

$70 \quad 1617$ Instructions, art. 47 , ibid. 37.

711617 Instructions, arts. 49-45, ibid. 38-39.
} 
the defence of the Company's position in the Moluccas and measures to be taken against the Iberian powers.

The next seventeen articles all concern regulations on private trade. ${ }^{72}$ Of the remaining articles of the 1617 instructions, one single article is dedicated to the settlement of expatriate Chinese in Company- controlled areas. ${ }^{73}$ The issue of provisions for the overall importance of the defence of the Company's possessions in the Moluccas is emphasised in article $75 .{ }^{74}$ The next two articles express the need to establish an independent rendezvous and the requirements that had to be met for it. ${ }^{75}$ Article 78 returns to the issue of war with the Portuguese with instructions to undertake a maritime campaign against them on an annual basis. ${ }^{76}$ The two concluding articles both confirm the powers and prerogatives of the High Government. ${ }^{77}$

\section{The role of and approach to diplomacy}

Although we may agree with Mijer that there is a more defined structure in the 1617 Instructions than there is in those of 1609 and 1613 , we should at the same time notice that diplomacy is not accorded a section of its own in the 1617 Instructions, either. It is treated in conjunction with respective relevant cases. These comments demonstrate a defined contrast. Advice on performance towards independent Asian princes recommends accommodation. Recommendations on how to approach the Iberian powers, which occur mostly in conjunction with the advice on the Moluccas, are bellicose, completely unlike the approach to the former. This pattern we have already seen in embryo in the 1609 Instructions and fully articulated in the Instructions of 1613 , and it is repeated in those of 1632 and 1650.

\section{The 1632 Instructions}

Of special interest in our context is that the Instructions for Governor- General Hendrik Brouwer and the Council of the Indies dated March 17, 1632, were

\footnotetext{
721617 Instructions, arts. 56-73, ibid. 39-43.

731617 Instructions, art. 74, ibid. 43.

741617 Instructions, art. 75, ibid. 43.

751617 Instructions, arts. 75 and 76 , ibid. 44.

761617 Instructions, art. 78 , ibid. 45.

771617 Instructions, arts. 79 and 8o, ibid. 45.
} 
the first after the Company had established Batavia as its Asian headquarters. It is thus not surprising that almost half of the ninety-six articles are dedicated to the administrative and judicial running of the Company's headquarters in the charter area. The 1620 s had witnessed a phase of geographical expansion of Company-trade, which is reflected in the more extensive advice on conduct in particular places of trade in the 1632 Instructions. Growing self-confidence given the successful repulsion of the attacks on Batavia in 1628 and 1629 must also be taken into account regarding the background of the 1632 Instructions. Fear of rising defence costs is a prominent topic in the 1632 Instructions, ${ }^{78}$ though not when it concerns the defence of the Company's possessions and monopoly rights in the Moluccas. ${ }^{79}$

\section{Contents and structure of the 1632 Instructions}

The 1632 Instructions have an even more defined structure than the preceding one. They can be split in three main parts. The first thirty-nine articles all concern the running of Batavia as a colonial institution, with articles 1-3 covering the administration of justice and the rest are devoted to various practical matters related to the daily running of Batavia. The next forty-six articles ${ }^{80}$ deal with the commercial regime and conduct of trade in the charter area. Particular instructions as to the Moluccas make up a considerable part of this section.

\section{The Moluccas}

Articles 63 to 80 are all dedicated to the Moluccas ${ }^{81}$ and cover such diverse issues as the repair and upkeep of defence works, ${ }^{82}$ measures to be taken against the illegal sale or production of cloves, ${ }^{83}$ and measures to be taken against Makassarese "smuggling" and influence in Ambon. ${ }^{84}$ This section also includes a proposal to replace the original population on Banda with slaves, a plan

\footnotetext{
78 For warnings against unnecessary defence costs, see arts. 19 and 33, Mijer, Verzameling van instructiën, 54,56

79 See below, 88-89.

801632 Instructions, arts. 40-86, Mijer, Verzameling van instructiën, 57-67.

811632 Instructions, arts. 62-65, ibid. 62-63.

821632 Instructions, arts. 63, 72, 69, and 79, ibid. 62-63, 64, 66. Art. 69, on Ambon, is on the reduction of the garrison, to economise the Company's expenses there.

831632 Instructions, arts. 65, 73, and 78, ibid.63-64, 65, 66.

841632 Instructions, arts. 66-68, and 8o, ibid. 64, 66.
} 
based on the assumption that, given their "inherently defect" human nature, trying to change the character of the Bandanese by schooling or religious instruction was useless. $^{85}$ As the policy on private trade from the 1617 Instructions had been reversed, a section of the 1632 Instructions includes six articles on the prohibition of private trade and sanctions to be used against those breaking it. ${ }^{86}$

There follow five articles that cover "miscellaneous" issues as the inspection of the factories outside Batavia, ${ }^{87}$ prohibitions on offering sea-transport to anyone who had travelled overland to Asia, ${ }^{88}$ and worries about the cost of keeping excessive numbers of slaves. ${ }^{89}$ The concluding article ends with an instruction to get rid of unqualified personnel, and a "mobilising appeal" to renew the Company servants' dedication to the Company.

\section{The treatment of diplomacy in the 1632 Instructions}

Diplomacy is not accorded a subsection in its own right in the 1632 Instructions. There is, for instance, no general formulation on "foreign policy" stating that international law is the foundation for overseas diplomacy equivalent to the statement in article 1 , which declares "the laws and practices in the United Provinces" to be the basis of the judicial regime in Batavia..$^{90}$ A parallel formulation explicating the legal foundations and general principles of diplomatic interaction with Asian princes seems alluringly close, but, as in its predecessors, the comments on diplomatic interactions with locals and approaches to rival Europeans are mixed with particular advice on the conduct of trade.

The 1632 Instructions, the sheer volume of advice on places of commercial operations in the second section taken into account, contains broader and richer material regarding explicit and implicit advice on diplomatic conduct

85 Het aanhouden van scholen aldaar, nademaal het naturel van de Bandanezen bevonden woort zoo kwaadaardig te zijn, dat er geen hoop is om deselve te verwinnen ... en daarom oordelen de kwaadaardige Bandanezen te versenden." 1632 Instructions, art. 75, Mijer, Verzameling van instructiën, 65-66.

861632 Instructions, arts. 84-90, ibid. 67-68.

871632 Instructions, art. 90, ibid. 67-68.

881632 Instructions, art. 94, ibid. 69.

891632 Instructions, art. 95, ibid. 69.

90 "eene regtmatige justitie ...mag worden bediend volgens de instructien en praktijken in de Vereenigde Nederlandsche Provinciën doorgaans.” 1632 Instructions, art. 1, ibid. 47. 
than the predecessors. I shall give some examples on the treatment of diplomacy to illustrate the complexity of the overseas diplomatic challenges, and the Directors' empirical and pragmatic approach to how to handle the Company's diplomatic challenges.

The section on the conduct of trade covers the Company's commercial operations from Persia to Japan. The articles concerning trade in Persia instruct how to deter the recurrence of English influence ${ }^{91}$ and how to present the Persian ruler with a "substantial gift" (eerlijke veerering) to improve bilateral relations. ${ }^{92}$ In three articles on trade between China and Japan via Formosa, ${ }^{93}$ the Directors approve a proposal suggesting submission to (demping) rather than accommodation with (onder sauvegarde) pirates in the South China Sea to get better access to trade in China. In that connection, it was deemed necessary drive the Spanish out of their stronghold on Formosa. ${ }^{94}$ Instructions for the use of violence against the Portuguese are repeated in article 62, which calls for systematic attacks on the Portuguese ships sailing between Japan and Macau. ${ }^{95}$ Both these articles primarily concerned access to trade. The common denominator regarding relations with the Asian states in question was accommodation, in the case of the Persians, gifts, and in the case of the Chinese, abstention from behaviour that might provoke retaliation. The advice on behaviour towards other Europeans was to minimise their local activities and influence, as in the case of the English in Persia, or to regularly oust them by military means, as with the Spanish in Formosa. This piece of advice summarises the Heeren XVII's general principle of overseas diplomacy with independent Asian polities of size and power well: Maximise friendly relations with the former, minimise the influence held by Europeans, and fight the latter when necessary. In the case of the Moluccas, the balance between the rose and the nailed glove was somewhat different. But both applied in the Moluccas too.

\footnotetext{
911632 Instructions, art. 40, Mijer, Verzameling van instructiën, 57.

921632 Instructions, art. 43 , ibid. 58.

931632 Instructions, arts. 56-58, ibid. 61.

941632 Instructions, art. 57, ibid. 61.

95 "om den Portuguesen dien handel infructueus te maken", 1632 Instructions, art. 62, ibid. 62.
} 


\section{The Moluccas: Political concerns and diplomacy}

The Moluccas fell under the category in which third-party influence had to be countered given the Company's sovereignty and monopoly rights on Ambon and the Banda islands. As we have seen, this meant military concerns of territorial defence and the ability to protect the Company's monopoly rights by force. But it also meant keeping a sharp eye on the other island polities in the Eastern Archipelago, and if possible trying to make alliances with them. Ternate was the obvious ally in the Eastern Archipelago in blocking Makassarese influence and actions in the archipelago. The 1632 Instructions offered a lengthy passage on how to sustain the alliance with Ternate. Article 64, on relations with the king of Ternate, reads:

Despite the fact we consider all this behaviour feigned, and try to keep him estranged from the Spanish, and support him with courteous compliments, under no circumstance must we, except for reasons of utmost importance, fall into conflict with him, which would jeopardise the cause of the Company and only serve the interests of the enemy.

Therefore, one must post rational, reasonable, and wise men there who would know how to defend the interest of the Company with competence ... because if we from our side act properly, we may to expect them to act in an obliging manner. ${ }^{96}$

If the stakes were higher in the Moluccas, the instructions on Ternate were in line with the advice on trade on Persia and China above. The latter two reflected a context where European rivalry meant a kind of "diplomatic competition" for local goodwill. That logic required men of tact and competence to handle relations with local power-holders more than intimate acquaintance with international law. This approach can be found as an assumption in all the General Instructions, but was explicated to the fullest in the 1650 Instructions.

96 De koning van Ternate "niettegenstaande Wij al zijn doen voor geveinsd, en hem vervreemd van den Spanjaard houden en met hoofsche complimenten onderhouden, en men geene, als om hoogwigtige redenen in rupture van vrede met hem te vervallen, waardoor de zaken van de Compagnie al te zeer verachteren en den vijand te groot voordeel op Ons krijgen zoude. Verstandige, kloeke vredzame persoonen, het regt van De Compagnie met goed beleid wetende te defenderen, dienen aldaar, zoo als hiervoor gezegd is, want als Wij van Onze zijde wel doen, kunnen van hen afvorderen 't geen zij schuldig zijn te presteren." 1632 Instructions, art. 64, ibid. 63. 


\section{The 1650 Instructions}

A tripartite order of the Company's diplomatic position and subsequent approach was formalised in the 1650 Instructions. The three categories were areas where the Company held sovereignty rights, areas where it held exclusive contracts, and areas where it had to trade on equal terms with other parties. ${ }^{97}$ Although an explicit formalisation of these categories was written down for the first time in the 1650 Instructions, the tripartite division is also discernible in prior Instructions. After all, the arrangement was taken over from the Portuguese..$^{98}$

The 1650 Instructions can be regarded as the richest source of information about the Heeren XVII's model of overseas diplomacy of all the General Instructions, not only for its explication of the Company's overseas diplomatic system, but for its sheer length-164 articles in all, covering places of operation across the whole charter area. Still the 1650 Instructions conform with their predecessors in that no one section or group of articles deals strictly with how to conduct bilateral diplomacy. Except for the article on the tripartite system, the advice on diplomatic mode was given in conjunction with specific cases. Not only did this case approach still apply, but as Mijer stresses, one of the peculiarities of the 1650 Instructions was its enhanced casuistic nature, which went both for approach and style. ${ }^{99}$ Still, it holds true that the 1650 Instructions also contained general observations and advice on the mode of the Company's operations, but as in the prior ones, such general advice appears in conjunction with or as generalisations from case comments.

Its comprehensive and practical nature helps explain why the 1650 Instructions was the last body of General Instructions for the Company. As late as 1746 , they were still acknowledged as the basis for the Company's operations in the charter area. ${ }^{100}$

\section{The context of the 1650 Instructions}

The years between 1632 and 1650 were the "dramatic period" of Van Diemen's governor-generalship, ${ }^{101}$ with its offensive against the Portuguese and bold

\footnotetext{
971650 Instructions, art. 18, ibid. 76.

98 C. G. Roelofsen, "De periode 1450-1712," in Compendium volkenrechtsgeschiedenis, edited by A. C. Eyffinger and C. H. Bezemer, (Deventer: Kluwer, 1991), 58.

99 Mijer, Verzameling van instructiën, "Inleiding," xi-xii.

100 Ibid. Inleiding, xiii.

101 Governor-General 1636-45.
} 
territorial expansion. With the death of Van Diemen and appointment of Van der Lijn as governor-general in $1646^{102}$ and the peace of Münster in 1648 , the Company was in for the less "dramatic" reign of Joan Maetsuyker (1653-78), characterised more by consolidation and securing prior gains than acquiring new ones. It should also be added that by 1650 , peace had been concluded with Batavia's two territorial neighbours on Java, Banten, and Mataram. ${ }^{103} \mathrm{~A}$ more immediate concern for the Directors in 1650 was about the moral fibre and conduct of their servants in the East, more specifically the twin problems of private trade and corruption. ${ }^{104}$ This went all the way to the very top, and perhaps proportionally so. Governor-General Van der Lijn was for instance allowed to seek retirement in an act of grace, but his second in command, Director-General Francois Caron, was called back to The Netherlands in 1650, on accusations of corruption. ${ }^{105}$ Thus rather than expansion, consolidation, both internal and external, was the keyword for the 1650 Instructions.

\section{Textual analysis, the 1650 Instructions}

As the 1650 General Instructions offer the richest material for a reconstruction of a Patriase model of diplomacy of the four extant Instructions, I shall analyse them in detail to demonstrate that, while the Directors' approach towards diplomatic performance should be viewed as pragmatic at the outset, this pragmatism became ultimately more embedded and increasingly explicit in the 1650 Instructions.

I start by giving an overview of the relative position of international law, and the advice on the relative position on the use of force versus accommodations and negotiations regarding the three categories of the 1650 Instructions. Here I draw particular attention to the emphasis that the Directors put on acquiring information about local conditions and affairs. After reviewing the "diplomatic model" of the 1650 Instructions, I return to its predecessors with an eye to demonstrating the extent to which the pragmatic model of diplomacy was developed or foreshadowed in these. I conclude by discussing whether, and on which grounds, it is fair to speak of a non-commercial ideological dimension

\footnotetext{
102 To be followed by Carel Reynierzoon in 1650.

103 In 1645 and 1646, respectively.

104 Stapel, Geschiedenis van Nederlandsch Indië, 285.

105 Ibid. 285.
} 
in the Directors' General Instructions that may have implications for the interpretation of its approach to and conceptualisation of overseas diplomacy.

\section{The balance between war and diplomacy regarding independent Asian princes}

As in all the General Instructions, the Company's possessions in the Moluccas, namely the areas that had been won by the sword and areas where the Company held contracts of exclusive privilege (covered in categories 1 and 2 of the 1650 division) were also to be defended by the sword. ${ }^{106}$ This relative position between diplomacy and war was inverted in category 3. The advice about Persia is quite explicit that war should only be resorted to as defensive retaliations and only when there were no other options at hand: "Our military might must only be applied against violence and injustice done against us, and then only when the grievances cannot be solved by peaceful means." ${ }^{107}$ The principle goal of the mercantilist diplomacy articulated in category 3 , where the Company held no special privilege, was to set down the terms for a treaty of trade. Its preferred means was peaceful negotiations. War was a means of last resort.

\section{Treaties and negotiations in category 3}

To understand the meaning of "treaty" in the nexus between the VOC and independent Asian states, one must first repeat the obvious: These contracts were vehicles for profitable trade. Where political matters were regulated, they were regulated with the intention of facilitating trade. It therefore seems more relevant to analyse these treaties as commercial contracts in which legal and political issues were addressed pragmatically as a means to secure profit rather than principally to secure an international order in its own right. At best, international law was a means to legitimise a political trading regime. But it did not form it. This is not to say that "law" had nothing to do with it, but in the process of the actual treaty making, it was secondary. The Directors' primary concern regarding the High Government's performance was that the latter negotiate the most profitable treaty possible. Their basic concern about the treating

\footnotetext{
1061650 Instructions, arts. 19 and 20, Mijer, Verzameling van instructiën, 76.

107 "Onze magt en wapenen....alleen gebruikt moeten worden tegen geweld en ongelijk, dat Ons aangedaan wordt, als hetzelve met vrede niet uit den weg kan gelegdworden.” 1650 Instructions, art. 72, ibid. 89.
} 
parties was that they honour their contractual obligations. This latter concern really amounted to a feeble hope that they could be trusted to do so. The difficulty of establishing contractual arrangements in Persia, for instance, was attributed to an inherent lack of trustworthiness on the part of the Persian people. Contracts with the Persians had "always been renewed under the most difficult and arduous conditions, due to the devious, proud nature of that people." ${ }^{108}$

By implication: To get a bilateral treaty with local rulers-and not least to convince them to stick to it-took both knowledge and skills. This is a point that is stressed repeatedly in the Instructions' advice on particular places of trade, far more often than specific comments on legal aspects per se. For one simple reason, I propose, the legal dimension lay in the right to conclude contracts of trade or make alliance bonds. The rest was left to improvisation. Guidelines for how this improvisation should proceed were offered in the Directors' advice on overseas diplomatic interaction but these were precisely general guidelines advocating contextual adaptation and pragmatism.

\section{Adaptation, accommodation, and pragmatism as the general principle in diplomatic interaction with rulers in category 3}

The heterogeneity of the overseas context in category 3 , which comprised polities of such different size and power as Tokugawa Japan, China, the Mughal, and Safavid Empires, on one hand, and lesser states and port polities in southern Indian and the Indonesian archipelago on the other, meant that the diplomatic mode had to be adjusted to a variety of local conditions and circumstances. This in turn begged for an awareness and appreciation of the particularity of context and local conditions and modes. In other words, diplomatic interaction in category 3 posed a challenge that by its very composite nature opposed a generalised "Eurocentric mode of thinking," if the Company should reach its goals. Here, the Company's submissive approach to defend their position in Japan is often pointed to. ${ }^{109}$ But

\footnotetext{
108 "Zoodanige contracten altijd vernieuwd geweest zijn met vele moeijelijkheden en vexatiën, naar den aard van die schrapende, superbe natie." 1650 Instructions, art. 67, ibid. 88.

109 See for Instance, Blussé and de Moor, Nederlanders Overzee, 227-28, and Van Goor, De Nederlandse Koloniën, 106-107.
} 
Japan was but one extreme case where the Directors' advice ran along the principle of "approach- diversification" dictated by particularities of local context. The 1650 Instructions actually propagate an advice that pragmatism must generally prevail.

The particular advice on the conduct of trade in Persia in the 1650 Instructions illustrates both the point of a case approach, and the way specific advice on a case could slide into more general ideas on transcultural diplomacy. Here the Directors' shifted their focus from particular advice to advocating a pragmatic, even cultural relativistic approach as a first principle of overseas diplomacy. They emphasise that the High Government must not try to enforce European standards in places where they "find the law and do not bring it." The only permissible principle is to adhere closely to local norms and rules: "The abovementioned trade cannot be pursued by applying our own standards or by use of force, as we (in these places) must adapt to existing laws, and not bring it." ${ }^{110}$ Intriguingly this relativistic and pragmatic stand is given a pedagogic counter-illustration by the Heeren XVII: Imposing one's own norms on autonomous Asian princes would be just as unacceptable as if outsiders should claim the right of interference in areas where the Company held legitimate control: "Just as the Company in the places under its jurisdiction would not tolerate it should any (outside) nations dictate its manner of operation by their own laws." 111

The recommended cultural relativism argued above was at the outset conditioned by the relative imbalance of strength in favour of the Safavid Empire. So, even though it could be argued that the above examples do not explicitly point to "cultural relativism" (an anachronistic term, in any case) as a general principle in the Directors' thinking, what stands out as the general rule is that the Company was instructed to assess local norms and follow them as far as need be. Different terms, same substance. The practical consequence of this pragmatic advice was cultural accommodation.

\footnotetext{
110 "Den vornoemden handel Ons op eigen concepten niet toeeigenen en zoodanige natiën met magt daartoe mogen constringeren Alwaar Wij de wetten vinden en niet brengen moeten." 1650 Instructions, art. 71. Mijer, Verzameling van instructiën, 89; emphasis in the original.

111 "Gelijk de Comp. ook niet verstaan zoude kunnen, dat op plaatsen onder haar gebied sorterende, andere natiën op de manier van handelen haar de wet zoude willen stellen." 1650 Instructions, art. 71, ibid. 89 .
} 


\section{Cultural accommodation}

Article 53 of the 1650 Instructions underlines the accommodating approach to be applied, taking particularly the pride of the people in the overseas areas into consideration. The article starts with a reminder of how misconduct has previously damaged the interests of the Company:

The differences regarding the relative value accorded to prestige by the Dutch and the Asian peoples must be taken into account in all the Company's dealings in the East ... the debauches of many Company servants in many quarters of India has caused setbacks in their daily dealings, whereby it is important to take into consideration that Asian peoples are very sensitive as to respect, and therefore harbour little affection for the Dutch nation. ${ }^{112}$

Put between the advice particular to Malacca and Sumatra, the generality of the message is all the same clear: Lack of appreciation of local ways and sensitivities was counterproductive to the goals of the Company. The way to further these goals was accommodation to local standards. The message was repeated in conjunction with the advice on Tonkin. "Take care not to cause the slightest offence to the king or his nobles" ${ }^{113}$ ran the counsel regarding North Vietnam.

Tonkin was of a strategic commercial importance in that it delivered silk that could be traded for silver in Japan. Its relation to the Company represented a typical category 3 constellation in that the Dutch could have no realistic hope of forcing their own conditions of trade upon the local rulers. The instructions on the Tonkin trade represent yet another example where the Directors go on to enunciate a principle of cultural relativism as the basis of Company diplomacy in places where it could not itself make the rules: "There is no alternative but to play the game according to local rules, especially in places where we are in no position to change things, but must conduct our trade on the basis of local laws." ${ }^{114}$

112 "Dat de debauche van vele Compagnie ministers in verscheiden kwartieren van Indië extraordinaire verachtering in de dagelijksche affaires geeft, waarbij geconsidereerd, dat de Indische natiën zeer gevoelig van hun respect zijnde, daardoor kleine affective tot de Nederlandsche natie zetten." 1650 Instructions, art. 53. ibid. 84 .

113 "Onze ministers zich voor al wachten moeten, om den Koning en den grooten van't rijk eenige de minste offensie te geven." 1650 Instructions, art. 116, ibid. 100.

114 "Niet anders te doen is, als anderen met gelijke munt te betaalen, zonder te denken op feitelijke resistentiën, inzonderheid op plaatsen, daar wij niets te zeggen hebben, maar ons naar de wetten van die landen op het stuk van den handel regulerenmoeten, 1650 Instructions, art. 116, ibid. 100. 
The Directors' reasoning regarding interaction with cases in category 3 was then that in some, if not most, of those places, "rules were different." As the Company was neither in a position, nor had the legitimate grounds, to change the rules, it must and should play by the local ones. But to do that, one needed Company servants who were culturally observant and knew how to "play the game" by the local rules.

\section{The desired quality of personnel}

General human qualities such as the ability to observe and accommodate local norms were the qualities that counted in the kind of personnel the Directors wanted to be appointed to positions in the places where the Company could dictate neither the law nor customs. "Do primarily base your conduct on modesty, humbleness, politeness, and amity; always acknowledging your inferior position," ran the advice to the governor in Deshima in the 1650 Instructions. ${ }^{115}$ Although Japan represented an extreme case, as already noted, in essence this advice represented the norm more than the exception with respect to desired personal conduct in category 3. Neither the 1609 nor the 1617 Instructions had such explicit remarks on "modesty" as a preferred quality, but the 1632 Instructions did. Regarding whom to appoint as governor of Ambon, for instance, the Directors stressed that he must be: "good natured, not arrogant; forthcoming towards the (local) inhabitants, and able to spot their sensibilities and accommodate them in minor matters."

Admittedly, Ambon was not an independent state, but the qualities and mode of performance sought for in prospective governors fit perfectly well with the recommendations for personal qualities and mode of performance in diplomatic interaction with independent states offered in the 1650 Instructions. The advice essentially came down to this: do not stir feelings of discontent or disrespect, accommodate to local standards, and be pragmatic so long as it serves the interest of the Company. This "principled pragmatism" also stands out as a defining trait in the Directors' advice on the respective means of diplomacy at hand in dealing with the Asian rulers in category 3 of the 1650 Instructions.

\footnotetext{
115 "Compagnie's ministers ...vooral gewapend moeten gaan met modestie, nederigheid, beleefdheid en vriendschap, altijd de minste zijnde." 1650 Instructions, art. 114, ibid. 99.
} 


\section{Means of diplomacy: The diplomatic gift}

Gift exchange and diplomatic missions were constituent elements in the diplomatic interaction in early modern Southeast Asia as it was in Europe. ${ }^{116}$ The exchange of gifts and, to a lesser degree, paying homage stand out as the two most important means for establishing or maintaining peaceful relations in both regions. In the overseas setting such gift giving and embassies were considered political "overhead" for the conduct of commercial transactions. In the advice on relations with Siam, the function of the gift as "grease money" is made quite explicit. Gifts must be seen as politico-diplomatic overhead to secure the prospects of profits from the trade in Siam: "In order to get the goodwill of the king and foreign minister of Siam, it is necessary to offer them annual gifts with compliments to their liking, and, given the great profits for the Company resulting from the trade there, no pettiness must be allowed as far as the costs are concerned." ${ }^{117}$ In other words: Today's politico-diplomatic investment is tomorrow's commercial gain, and the two must be calculated in relation to each other.

\section{Notions of cultural relativism and pragmatic accommodation to local ways in the pre-1650 General Instructions}

Article 10 of the 1609 Instructions illustrates how pragmatism was built into the Directors perception of overseas diplomacy from the start. The article states that the Company must gather information on Asian princes and their ways of trade and on the standing of the Portuguese; but it also puts emphasis on the need to gather information about the political situation in different ports of call. The article opens with an order to "accurately inform the Directors of the circumstances, the feelings, and approach of "each and every single one"

\footnotetext{
116 For a balanced comparison between European and Asian diplomatic systems and modes in the Early modern period, see Jeremy Black, A History of Diplomacy (London: Reaktion Books, 2010), $33 \mathrm{ff}$.

117 "De gunst van de grooten te mogen capteren, de Koning en Berquelang met jaarlijksch vereering, hun aangenaam zijnde, begroet moet worden; welcke kosten, ten aanzien van de groote commoditeit daaruit voor de Compagnie resulterende, op profijt aangelegd worden, en derhalven niet te menagerende mogen zijn.” 1650 Instructions, art. 85, Mijer, Verzameling van instructiën, 92.
} 
of the kings, nations and peoples over the whole of Asia where the Company conducts or is licensed to conduct trade." ${ }^{118}$

The pursuit of information must be understood as being sought after because it was instrumental to trade, but the desired knowledge was not restricted to matters of commerce alone. Included was information about the diplomatic relations between local rulers, as well as their relations with other Europeans. The governorgeneral and Council were instructed to take note of Asian princes' relations with the Portuguese and others: Who were their enemies? Who were their friends? And what were the legal foundations and considerations of their relationships? The quest for this kind of information was obviously motivated by the Company's struggle to wrest control of the trade dominated by the Portuguese. Still, in the overseas context, this struggle was a triangular affair with the commercial prospects and political stand of Asian trading states as one of the dimensions. To get a better idea of the Asian dimension, the Directors asked for information not only of the current state of politico-diplomatic stands of the Asian princes, but also about their political and economic power and diplomatic performance towards the Portuguese and the Dutch in the past. The article goes on to specify the kind of information one should look for. Information about Asian polities was thus not restricted to trade relations, it was meant to serve the purpose of establishing and easing the Company's diplomatic relations with them:

"One therefore must seek information about domestic politics: such as "specifically by whom and in what manner all the respective states were governed in all matters, (and) by which means to communicate and establish relations with them, and consistently increase the Company's pool of knowledge."119

What is being demonstrated here is that already in the first of the General Instructions, the Directors regarded information on local conditions of power, politics, and policy as the foundation for the Company's success when interacting with independent Asian rulers. Although the implications for diplomatic practice could have been more explicit, the message is nonetheless clear: The Directors

118 "Zult gij U pertentelijk informeren op de genegenheid, affection en gunsten van alle en een iegelijke koningen, natiën en volken van de gansche kwartieren van India ... om te weten, welcke gunst en genegenheid dezelve koningen, natiën of volken tot den handel met die van de Compagnie zijn hebbende." 1609 Instructions, art. 10, ibid. 8.

119 "als te weten: hoe, bij wie en welke personen alle zaken in de resp. Rijken gereegeerd worden; wat middel, om communicatie en access hij dezelve te hebben, aangewend moet worden, ... goede intelligentie ...zooveel mogelijk is te vermeerderen.” 1609 Instructions, art. 10, ibid. 8. 
were not ethnographers, they were men of business, and the information they sought served the purpose of establishing and preserving profitable trade relations. No sane person with that intention would go about it by breaking local customs and rules or challenging the local rulers and authorities. The pragmatic approach and accommodating mode outlined in the 1650 Instructions is implicitly preconceived in the emphasis laid on the importance of gathering information about Asian rulers, their politics, and their policies in the 1609 Instructions.

Squeezed between an article on the general conduct of trade and particular advice on the trade in the Moluccas, ${ }^{120}$ article 21 of the 1609 Instructions entails a formulation that comes as close as it can to a full enunciation of pragmatism and accommodation in diplomatic relations: "As for good correspondence with the kings in Asia," the Directors wrote, admittedly making no reference to diplomatic correspondence in particular, but implicitly including it, they considered themselves unable to give any specific advice, but would in general remark that the perseverance of the Company's trade in Asia now and in the future depended on such contact. Therefore, the governor-general and Council was advised to "proceed with caution and act discretely" in deciding whom to befriend and whom to consider the Company's enemies, whether from concerns about trade or for other reasons. ${ }^{121} \mathrm{I}$ take this to foreshadow the more explicit elaborations of a culturally accommodated approach in the 1650 Instructions.

\section{International law and "treaty" in the 1609 Instructions}

The 1609 Instructions state that law was the foundation upon which to build the Company's interaction with Asian rulers. Having considered who to fight and who to make friends with "on the basis of law" (materie van state), all contracts of friendship relations or alliances guaranteeing the Company free access to trade had to be based on the same legal footing. The Directors do not use the phrase regt van alle volkeren or any other seventeenth-century synonym for "international law," but what they had in mind must have been the universal

\footnotetext{
1201609 Instructions, arts. 20 and 22, respectively, ibid. 13.

121 "Belangende alle goede correspondentiën met de koningen van Indië te houden, daarop kunnen Wij U geen particulariere vaste instructie geven, maar in 'tgeneraal zeggen, dat aan 't zelve een goed deel van de conservatie van den handel voor Onsen Onze nakomelingen gelegen is, zulcks gij U dienshalve zeer wijselijk, voorzigtelijk en gansch discretelijk moet gedragen, wie om haar profijt of uit haar eigen belang Uwe vrienden of vijanden behoeven of te zijn." 1609 Instructions, art. 21, ibid. 13.
} 
right to trade, given by the principles of natural law, ${ }^{122}$ as the basis for bilateral treaties to regulate conditions for and terms of trade. But of the two, the latter took precedence, and besides that, the treaty was but the tip of the iceberg following negotiations or war. The diplomatic effort proper lay in the challenge of getting a treaty.

International law primarily came into the picture as a basis for the appeal to get it, and the defence of it in the case of third party intrusion. Still bilateral negotiations centred on the treaty were thus the crux of the Company's overseas diplomacy. This explains the emphasis on information about local context and conditions. Assessing the prospects for securing a treaty and the right performance in getting it were dependent on accurate assessments of local conditions. Implicitly contextual awareness and cultural sensitivity were vital to successful diplomatic performance. This is the same kind of configuration between information-gathering and pragmatic diplomatic performance and treaty making that we find fully elaborated in the 1650 Instructions.

This "pragmatic package" can also be found in the 1613, 1617 and 1632 Instructions, as we have seen, articles no 21 of the 1613 and no 45 of the 1617 Instructions more or less repeat the wording of article 21 of the 1609 Instructions by stating that the High Government must keep its correspondence and make friendships and alliances with "all the kings, princes, republics, and men of power" in Asia with all due discretion and caution," yet again leaving the actual decisions about how to proceed up to the High Government, as it "thought best in the interest of the Company." ${ }^{123}$ Significantly, however, the 1617 Instructions add, like those of 1613 , that the Company's performance on the ground must generally be conducted in a manner "not to offend anyone or to run into conflict and war with anyone over petty matters." ${ }^{124}$ If the term "accommodate" was not used, that was still the core of the message.

Although the Directors' basic approach regarding the purpose and mode of diplomacy remains the same in 1617 as in 1609 and 1613, there are differences. The naming of the Asian counterparts in general terms as "the kings, nations, and peoples" in 1609 and in the same general terms in 1613 is replaced by a more nuanced terminology in 1617 which then included "kings, princes,

\footnotetext{
122 Roelofsen, "De periode 1450-1712," 91-92.

1231613 Instructions, art. 21, Stapel (ed.) 1943, 550-51, 1617 Instructions, art. 45, Mijer, Verzameling van instructiën, 37.

124 Ibid. 37.
} 
republics, and men of power." ${ }^{125}$ One should be careful to read too much into such differences but still the difference might be taken as an indication of growth of knowledge about the Asian counterparts that had taken place in the eight years between the two sets of instructions. If this is correct, the difference in wording supports the proposition that the Directors' understanding of overseas diplomacy was subject to a dynamic learning process. Another difference is that the 1609 and 1613 explicit insistence on law as the basis of interaction and relations with Asian rulers was left out in 1617. Possibly the formal legal footing went without saying, but it might also reflect that legal justifications did not constitute the primary challenge in making treaties.

In the 1632 Instructions, regarding trade on Siam, an appeal for accommodation and pragmatism is made explicit. To get a firm foothold in the Siam trade, the Directors had discussed whether to approach the king directly or to approach subaltern ministers responsible for the trade ${ }^{126}$ in a specific area. It was stressed that, if, and when doing so, one should at the same time take care to stay on good terms and conduct regular correspondence with the kings' ministers at court. ${ }^{127}$ The advice sprang from fear that a direct approach to the king's ministers at the regional level might cause royal offence. The Directors ended up by stating that the advice regarding Siam could serve as a general example, in that the governor-general and Council must "seek to have all disagreements that may prop up tackled in a way that would best serve the interests of the Company." ${ }^{128}$

In this case the Directors did not consider it sufficient or relevant to act dogmatically and try to force the Company's rights by reference to international law. The process of negotiating terms of access to, and rules for the conduct of trade was far too concrete and specific than to be handled by in general terms of law in the final instance. The Directors knew this in 1632, as they did in 1609,1613 and 1617 , even if they would most unequivocally express it in 1650. If cultural sensitivity, accommodation to local norms and pragmatism in negotiating the political terms of trade with independent Asian rulers were

\footnotetext{
125 "Alle koningen, prinsen, republikeinen en heeren." Ibid. 37.

126 "gedelibereerd zijnde, of met den handel met den koning of met particuieren ... stabiliëren zoude." 1632 Instructions, art. 41, ibid. 57.

127 "Houdende nietteminmet Malambeek en alle andere van den koning dependererende goede vriendschap en correspondentie." 1632 Instructions, art. 41, ibid. 57.

128 "Alle openstaande dissentiën ten meesten dienste van de Compagnie zoude zoeken af te handelen." 1632 Instructions, art. 41, ibid. 58.
} 
only fully explicated in the 1650 Instructions, these precautions were no doubt all foreshadowed and if not fully expressed in the preceding Instructions.

\section{Conclusion: The Directors' model of overseas diplomacy in the General Instructions, 1609-50}

Pragmatism was the Directors' recommended means to get what the Company wanted in a political environment different from their own. International law could only do so much: Give legitimacy to the claim to trade on par with third parties in category 3 , and legitimise sovereignty and exclusive monopoly rights in the Moluccas, that is categories 1 and 2 of the 1650 Instructions. But this is where the function of international law stopped. The basic building block of the Company's overseas interaction regime remained the bilateral treaty concluded on site and designed to meet the requirements defined by local conditions and policies. That is why the Directors' General Instructions bore the stamp of a principled pragmatism. That in its turn was founded on an assumption of cultural difference.

\section{Section 3: Commerce, diplomacy, and ideology}

I have so far treated the Directors' advice on diplomacy as embedded in a pragmatic, commercial logic. I think that was the core of it, but this still does not give us the whole picture. There was also an idealistic-and not necessarily ideological- dimension as far as values and motives were concerned.

Configuring a hierarchy of values or means-to-an-end relations in the General Instructions on one hand puts one in the position of repeating the obvious. The Company was a commercial institution, and its primary purpose was to conduct profitable trade: "De eenige ziel van's Comp. lichaam zijnde." ${ }^{129}$ By simple inference, diplomacy and treaty making served the purpose of facilitating profitable trade first and foremost. But the question remains whether "profit" was the sole motive or reigned supreme in the Directors' worldview. The evidence strongly suggests that commercial concerns were not only intermixed with noncommercial concerns, but that some of the latter were treasured as values by their own right. Pride in power and prestige are two candidates that stand out.

1291650 Instructions, art. 123, particular advice on Coromandel, Ibid. 102. 
Qualifying the proposition that the pursuit of the "Glory of the Company" may have been a motive by its own right for the Directors is that such appeals may well have been instrumental to the accumulation of diplomatic capital. Still, my point is that whatever the exact configuration of the relationship between means and ends with respect to concerns other than profit, a survey of the more encompassing package of mixed concerns that I do find points to the fact that the Directors' perspective was broader than the proposition of a singular and all dominating profit motive suggests.

I shall narrow the problem down to how non-commercial concerns were presented in the Directors' General Instructions. Whether they served legitimating purposes or were conceived as values in themselves is difficult to tell, but generally, my proposition is that the rational "Reasons of Company" thinking was supplemented by "idealistic," moral-religious, and even emotional dimensions.

\section{The Company's success as providential blessing}

As for the evidence of religious appeal in the Directors' General Instructions, I have tried to leave out the instances where references to "higher powers" (God) are purely conventional. My focus will be on instances where the Directors depict the venture of the Company as part of a "greater plan" and interpret its successes as a sign of "providential blessings." Such appeals are particularly found in the closing paragraphs where the Company's secular success is portrayed as evidence of providential blessings for a righteous, "higher" cause. The two are depicted as two sides of the same coin.

The concluding article of the 1650 Instructions ${ }^{130}$ for instance is clearly intended as an ideological spur to the High Government's total commitment to the cause of the Company. It starts with a reminder to the members of the High Government that they "may every day dedicate all of your thoughts and interventions to the general and particular workings of the Company." ${ }^{131}$

The commitment of the High Government is then put into a religious perspective. All their efforts "will fall upon them lightly, especially as God himself,

\footnotetext{
1301650 Instructions, art. 164, Mijer, Verzameling van instructiën, 115-16.

131 "Dat Ued. Alle Uwe gedachten en mediatiën op het generaal en particullier werk van de Comp. dagelijks latende gaan.” 1650 Instructions, art. 164, ibid.
} 
who knows what is best for man, will give the work his blessings." 132 The "conceptual figure" or "moral lesson" here is that there exists a heavenly ordained symmetrical relation between worldly efforts and returns on earth. Dedicated work brings its reward by God's blessing-a Company variety of Devotio moderna, or a connection between "the Protestant ethic and a "Spirit of Company", if you wish. In the following paragraph from article 164, however, it is not so much heavenly returns that are stressed, but the more mundane returns for the Company to be earned by a collective high moral standard and the dedication of its servants in all fields of office:

But, as all good deeds finally depend on the moral example of the persons in charge, must we remind you members of the High Government and the Councillors of the Indies to serve collectively as an exemplary model in all your domains of office, execution of justice, law-enforcement, trade and all other matters. ${ }^{133}$

One should of course be careful not to read too much into such formulations. Cynically read, the text might basically mean, "Stop your individual smuggling." But what is also clear is that the Directors' stress that just as righteous conduct has rewards and blessings at the individual level, so does the Company's success as a corporate body depend on the virtue and moral conduct of the High Government as a collective body.

In the final paragraph of article 164, a unity of morals at the individual- and at the corporate level is linked together. Committed service to the Company according to the "laws of God" would bring it secular rewards guaranteed by providential blessings:

That you Councillors of the Company should take the interest of the Company so to your heart that the long-awaited fruits may be anticipated, for which we pray to the Lord that you jointly, will be spared all 'misfortunes', and that he will bless trade more and more under his long continuing blessings and protection. ${ }^{134}$

\footnotetext{
132 "zeer ligt en onbezwaard toevallen zal, inzonderheid als God de Heere, die weet wat den mensch nut is, 't zelve gelieft te zegenen." 1650 Instructions, art. 164, ibid.

133 "Maar gelijk alle deugden haar gevolgen krijgen uit goede opperhoofden en voorgangers wordt UEd. En den Raden van Indië geszamentlijk, als een lichaam representerende, ten hooghste gerecommandeerd med goede exempelen in de justicie, policie, handel en al hetgeen daarvan verder dependert, te toonen." 1650 Instructions, art. 164, ibid. 116.

134 "Dat Ued. Het welvaren van deze loffelijke Nederlandsche geocrtoijeerde Oost- Indische Comp. zoo te harte gaat, dat daarvan de lang verwachte vruchten te gemoet mogen zien waartoe wij God den Heere bidden, Ued. te zamen en in het bijzonder voor alle ongeluk en onheil te bewaren, den handel van
} 
The same linking of God and the Company's success is found, although in a somewhat different form, in article 10 of the 1609 Instructions, which summarises the general aim and purpose of the Company as being "Not only to continue, but to seek to increase and broaden the commercial activities in the name of Christ, to the salvation of the non-Christian peoples, to the honour and respect of our Nation and to the benefit of the Company, in all possible ways." ${ }^{135}$

As it stands, it is not explicitly made clear what the priorities among mission, national glory, and profitable trade should be. In fact, article 10 could be read to mean that trade was instrumental to mission (den handel tot verbreiding), but this was quite simply not the case, for the Company's commercial mission was restricted to areas conquered from the Portuguese, and colonisation schemes such as that on the island of Formosa were the exception.

We find a more secular "trinity" in article 20 of the 1609 Instructions, which concerns the Company's intra-Asian trade. The Directors do not find themselves in position to give specific advice on this, but in general the trade must be conducted to "serve the Republic, accrue profit to the Company, and protect and defend the honour of the Company". "Go "God" re-enters the trinity in the following article, however, at the expense of the Company's honour: "Our friendship and trade must be promoted and carried out to the glory of the Lord, the well- being of the country, and the profit of the Company."137

In the concluding article of the 1632 Instructions, heavenly providence and corporate commitment are called upon in the following manner: "That the prosperity of the honourable United Company so goes to your heart that we may reap the fruits, for which we pray God to spare you from all mischiefs and accidents, (and) to preserve the trade of the Indies." ${ }^{38}$

Inidië onder Ued. beleid meeren meer te zegenen, en onder Zijne heilige bescherming lang voorspoedig te willen houden." 1650 Instructions, art. 164, ibid. 116.

135 "Om den Oost-Indischen handel tot verbreiding van den naam van Christus, zaligheden der onchristenen, eere en reputatie van Onse natie, ten profijt van de Comp. niet alleen te continueren, maar bij alle mogelijke middelen en wegen te vergrooten." 1609 Instructions, art. 10, ibid. 8., and is repeated almost word by word in article 10 of the 1613 Instructions, Stapel (ed.) 1943, 547.

1361609 Instructions, art. 20, Mijer, Verzameling van instructiën, 13.

137 "Onzen voet in Indië vast, Onze vriendschappen en de trafique tot Godes eere, der Landen welvaart, en den Comp. Profijt bevorderd en gedreven mag worden." 1609 Instructions, art. 21, ibid. 13.

138 "Dat U.Ed. het welvaren van de loffelijk Vereenigde Geooctroieerde Oost Indische Comp. Zoo ter harte gaat, dat daarvan de vruchten zullen mogen tegemoet zien, waartoe God bidden U.Ed. voor alle onheilen en ongelucken te bewaren, den handel van Indie te willen onderhouden." 1632 Instructions, art. 96, ibid. 70 . 
Here, then, we encounter the same configuration as in the 1650 Instructions: Individual commitment to the Company is likened to taking part in an endeavour for a collective body under heavenly blessings.

References to "God" or appeals to a "higher order" are also invoked as a source of consolation and encouragement in the face of hardship. In the concluding paragraph of article 72 of the 1650 Instructions (concerning trade with Persia), the High Government is instructed not to retaliate violently to local injustice or harassment, unless clearly provoked to do so, and then only as a last resort. The sufferings and injustice that may be inflicted upon the Dutch should instead be viewed with calm and as being temporary. At the end of the day, seen from the perspective of cosmological justice, the wrongdoers would be punished and those showing restraint and righteous conduct rewarded: "Just as one must never lose confidence in the justice of God, it is our aim that those who follow evil ways will receive punishment, just as those who follow the righteous path in this behaviour can expect God's blessings." ${ }^{139}$

There is a common denominator in all these references to the providential dimension to the Company's venture. Divine blessing is consistently linked to the secular success of the Company, which again is combined with an implicit or explicit appeal to individual commitment and dedication to the execution of work in the Company's service. What is particularly relevant in this context is the relationship between means and ends; in the final instance providence and individual morale are both seen as means to the Company's collective success. This is, I think, as far as we can get in trying to establish a more general worldview or ideological framework from the Generale Instructiens. It represents a raison de compagnie argument, mixed with corporate pride, and a sense of belonging to the happy few. This has implications for the understanding of the Directors' diplomatic model in the sense that it is hard to imagine that diplomacy was perceived as being extrinsic to moral standards or void of emotions or motives of prestige and pride. I would thus propose that although the Directors' thought in pragmatic terms, their thinking also had an idealistic component. However, the idealistic dimension mentioned to in the above, is less evident in the advice on Makassar in the particular letters from the Directors to the High Government.

139 "Gelijk aan Gods rechtvaardigheid geenzins getwijfeld mag worden, zoo gaat ook zeker, dat degenen, die onregtvaardig wegen inslaan, de straffen daarvan gevoelen zullen, maar degene den regten weg in hunnen handel volgende, Gods zegen daarop te verwachten hebben." 1650 Instructions, art. 72, ibid. 80. 


\section{Section 4: Approaches to diplomacy in the entries on Makassar in the particular patriase letters to the High Government 1634-1669}

\section{Section introduction}

All in all, nineteen entries were made about Makassar in the particular patriase letters to the High Government in the period covered by my study ${ }^{140}$. The first is a comment on illicit trade via Makassar in a letter of September $3,1634,{ }^{141}$ and the final ones are two comments in a letter of May $9,1669^{142}$ on the situation after the various peace settlements with Makassar 1667-68.

The Directors' remarks and advice on Makassar cover a wide range of issues such as smuggling of spices via Makassar, as in the letters of September 2, 1634, April 21, $1635^{143}$ and September $25,1642,{ }^{144}$ or where to buy sappanwood of the best quality ${ }^{145}$. Whereas one entry occupies itself with taking actions to secure the supply of rice from Makassar, ${ }^{146}$ another concerns technical details on modes of payment and credit $^{147}$ and yet another gives orders not to enter "imaginary profits" into the bookkeeping. ${ }^{148}$ None of the above entries will be analysed here however, as I shall concentrate on comments which contain implicit perceptions or explicit remarks on policy and mode of diplomacy towards Makassar.

140 The sources consulted in this subsection are respectively: Johan van Hoorn's book of extracts of letters by the XVII to the GGs 1629-1697: Notulen getrocken uijt debrieven van de Heeren Bewindhebberen van de Generale Nederlandsche Geoctroijeerde Oostindische Compagnie ter Vergadering vande Seventienen: Beginnende met die van den 28 Augustij anno 1629 en Eijndigende met die van 27 December 1697, KITLV, collection H 45, from now on: "Van Hoorn, Notulen", and the original letters in the NA: VOC, 1.04.02, Invnrs. 316-319.

141 Patriase letter, September 3, 1634, Van Hoorn, Notulen, fol. 7: NA, Inv.nr. 316 fol. 45b.

142 Patriase letter, May 9 1669, two entries, Van Hoorn, Notulen, fol. 108b and 113b respectively. NA, Inv. nr. 319, unf.

143 Patriase letter, April 21, 1635, Van Hoorn, Notulen, fol. 7b, NA, invnr. 316, fol. 67b.

144 Patriase letter, September 25, 1642, Van Hoorn, Notulen, fol. 14b, NA, invnr. 350, fol. 380-38ob.

145 Patriase letter April 7, 1663, Van Hoorn, fol. 74. NA, invnr. 318, fol. 591.

146 Patriase letter September 21, 1644, Van Hoorn, fol. 17., NA, invnr. 317, fol. 3 b-4.

147 Patriase letter April 29, 1664, Van Hoorn, Notulen, fol. 78 b, NA, invnr. 351, fol.666-667.

148 Imaginereede winsten de boeken te brengen, Patriase letter 7 November 1665, Van Hoorn, Notulen, fol. 89, NA, invnr 351 , fol. 814 . 


\section{Letters containing politico-diplomatic implications or direct advice on diplomatic approach}

The particular patriase letters containing direct and specific advice on policy and mode of diplomacy towards Makassar are in chronological order the letters of: September 22, 1648, October 13, 1656, October 9, 1657, August 23, 1661, August 24, 1663, October 23, 1666, May 14, 1667, August 22, 1668 and of May 9, 1669, already mentioned.

In their letter of September 10, 1650, the Directors called upon the High Government to "evict all Portuguese from Batavia and close all other Company residencies to them as their presence was "bad for the Company." ${ }^{149}$ Considering the strong Portuguese position in Makassar, this obviously indirectly had to do with Company relations with Makassar, but the entry contained no further explicit advice on how the High Government should act towards the Sultanate or the Portuguese there, and thus falls outside the sample of policy advice concerning Makassar.

Within the sample of advice on policy towards Makassar proper, the series of letters up to October 23, 1666 is broken by insertions of advice on practical and commercial matters as already noted above. But in the letters after the sending of Speelman's expedition in 1666 up to and including the ones of May 9, 1669 the patriase comments on Makassar form an unbroken chain of reflections and advice. I shall analyse the Directors' view in the whole sample with an eye to how it fits in with or contradicts my findings in the analysis of the Directors' model of diplomacy in the General Instructions.

I have not been able to find any comments by the Directors on the 1637 Treaty. The first entry containing direct advice on mode of diplomacy is thus in the letter of September 22, 1648, where the subject is whether the Company should go to war or find peaceful solutions with Makassar. The Directors come up with a strong advocacy for the latter: a war against Makassar is hard to win, and one should strive to maintain the friendship so as not to end up with even more enemies. The ideal situation was to continue "trading in peace" 150.

\footnotetext{
149 Batavia en alle andere residentien van de Comp: Van de Portuguesen Suyveren, en deselve aldaar geen toegange meer geven ... als quaat voor de Comp., Patriase letter, September 10, 1650, Van Hoorn, Notulen, fol. 32, NA, Invnr. 317 , fol. 89 b.

150 om met selver (Makassar) in vriendschap te blyven om geen meer vyanden op onsen hals te hebben ... vreedsame negotie, Patriase letter, September 22, 1648, Van Hoorn, fol. 25b, NA, Invnr. 317, fol. 111.
} 
The letter of October 13, 1656 also concerns the issue of war and peace, but this time in a more immediate context, because of the Directors' fears that the Company might become involved in a war with Mataram and Banten. The High Government is therefore recommended to keep peace with Makassar to avoid a situation where the Company is "threatened from all sides"151.

When in the letter of Oct. 9, 1657, the High Government is reminded by the Directors to just keep an eye on Makassar with no other specific instructions, ${ }^{152}$ it falls in line with the fears of falling into war and the wish to avoid it as expressed in both 1648 and 1656 .

The comments on Makassar in the patriase letter of August 23, 1661, written in the aftermath of the successful campaign against Makassar in 1660, are more specific than the prior ones. The Directors start by expressing their joy over the victory in the general and the destruction of Portuguese ships at the Makassarese roadstead in particular. Then they go on to emphasise that when the Makassarese had been forced to conclude "such an advantageous peace", it contributed to increasing the Company's reputation in the area ${ }^{153}$. But except for the congratulations on the victory and the comment regarding the increased standing the victory gave the Company, no concrete advice or instructions on policy were offered.

More concrete and specific advice was given in the letter of August 24, 1663, however, where the High Government was asked to approach and invite the Sultan of Ternate's brother, Calamatta to Batavia instead of having him walk freely in Makassar which meant "running the risk that he might conspire with the English." ${ }^{154}$ This advice thus conforms to the cautious reminders we saw in the letters of September 22, 1648, October 13, 1656, and Oct. 9, 1657, except that in 1663 the caution took the form of preempting tactics to guard against any third party scheming to undermine the peace with Makassar.

\footnotetext{
151 den Mataram ende Bantam ....ons van alle kanten op luyf souden vallen, Patriase letter, October 13 1656, Van Hoorn, Notulen fol. 48, NA, Invnr. 317, fol. 450.

152 To keep an eye on the goings on in Makassar, Patriase letter Oct. 9, 1657, Van Hoorn, Notulen, fol. 52b, NA, Invnr. 317 , fol. 508b-509.

153 (de vrede) nu soo avantagieus gesloten zynde, sal het selve geen kleyne luyster aan 't Comp. Reputatie d’omleggende gewesten geven, Patriase letter of August 23, 1661, Van Hoorn, fol. 65b. NA, Invnr. 318, fol. 406-407.

154 dan pericuel te lopen darby op Macassar blyvende ofte sigh onder Engelse begevende, Patriase letter August 24, 1663, Van Hoorn, Notulen fol. 76, NA Invnr. 351, fol. 611.
} 
In the letter of October 23, 1666, the Directors state that they are awaiting what will eventually happen regarding the relations with Makassar, but repeat their general advice to stay out of trouble and conflict, while at the same time stressing that the High Government must consolidate the Company's position in the Eastern quarters. ${ }^{155}$ In other words the Directors' comments reflect a combination of calling for caution and advising that necessary precautions be taken. In the former respect the advice represents an echo of prior ones.

Even more so does the following letter of May 14, 1667, where the appeal to seek peaceful solutions once again is voiced. In 1667 the appeal for peaceful solutions starts by the Directors expressing their hopes that relations with Makassar would improve, and that the Company would soon be allowed to trade there again. ${ }^{156}$ Then an implicit statement of recommended policy is offered by stating that "lately the Company had had good profitable trade and made advances in Makassar" ${ }^{157}$. The implication is clearly that because of the war, trade had suffered and that the Directors were looking forward to an ending of the war so that peaceful relations and thereby profitable trade could be resumed.

With the news of Speelman's victories in the fall of $1667^{158}$ the Directors' cautious tone changed somewhat, but not without qualifications. The section on Makassar in the letter of August 22, 1668 started with the Directors' congratulations on Spellman's "great victory", and then went straight on to express the wish for the conclusion of an "honourable peace." The latter point was expressed as a matter of some urgency however, as the Directors expressed their doubts as to whether the Company would have the necessary military might to keep the Makassarese suppressed for long. ${ }^{159}$ Unnecessary continuation of the war would in addition mean a non-wished for draw on limited

\footnotetext{
155 blyven de Heeren afwagten, met recommandatie om met dat ryk (Makassar) buyten werveyderinge en hostiliteyten te blyven, .... in de oosterse quartieren te consolideren, Patriase letter October 23, 1666, Van Hoorn, Notulen fol. 91b, NA Invnr. 319, unf.

156 Hopen dat de saken met Maccassar ten beter sullen uytvallen, en wy daarverder geadmittert, Patriase letter May 14, 1667, Van Hoorn, Notulen fol. 93. NA Invnr. 319, unf.

157 geen vordeligh ... een considerable negotie en... goede advancen gehad, Patriase letter May 14, 1667, Van Hoorn, Notulen fol. 93. NA Invnr. 319, unf.

158 See chapter 1 and on the Bongaya treaty in chapter 8 .

159 dat hierop een honorable vrede gevolgt was, alsoo ' $t$ niet apparent is, wymet continuatie onser wapenen met voordeel, de Makassaren geheel t’onder sullenbrengen, Patriase letter August 22, 1668, Van Hoorn, Notulen fol. 105.: NA Invnr. 319, unf.
} 
resources that were needed elsewhere, for instance Ceylon, they pointed out. ${ }^{160}$ In support of establishing a final peace settlement as soon as possible, the Directors also argued that the Company in dealing with the Makassarese was "dealing with people of a stubborn nature." ${ }^{161}$ A prolonged war might thus well mean that the Makassarese would become even more dedicated in their struggle against the Company. ${ }^{162}$

The Directors' comments on how to deal with Makassar after the victories of 1667 thus on the one hand expresses pride in the Company's victories but on the other hand also worries that a final settlement be established as quickly as possible so as not to jeopardize the Company's current advantageous position. This ambiguity signals that the Directors in autumn of 1668 perceived the Company's position in relation to Makassar had not been radically changed so as to call for a reconstruction of the political map of South Sulawesi with the Company as hegemon, which in fact became the de facto result of the war. The Directors' mode of arguing in August 1668 however much jubilant, was still one basically characterised by caution and restraint.

There are two entries about Makassar in the patriase letter of May 9, 1669. The first entry is based on news in a letter from Speelman that the Makassarese have guns and are able in using them. Apart from worries over this fact, the Bewindhebbers state that victory over Makassar depends on the support of the Bugis. ${ }^{163}$ The tone in the entry that followed is far more optimistic, here the Directors express their surprise that the High Government had been able to humiliate the Makassarese to accept such a "dishonourable and unfavourable contract of accommodating submission." ${ }^{164}$

The two entries on Makassar in the May 1669 letter must have been entered respectively before and after knowledge of the contracts with Prince Tello and Karaung Linques in Mars 1668, which finally secured the settlement of the

\footnotetext{
160 daar ....op Ceylon soo noodige is, Patriase letter August 22, 1668 Van Hoorn, Notulen fol. 105.: NA Invnr. 319, unf.

161 uit een hartneckigh wolck te doen heben, Patriase letter, August 22, 1668, Van Hoorn, Notulen fol. 105. NA Invnr. 319, unf.

162 de Makassaren by langere continuatie van den Oorlog ...dardor te stoutmoedigen worden, Patriase letter, August 22, 1668, Van Hoorn, Notulen fol. 105. NA Invnr. 319, unf.

163 Patriase letter, May 9, 1669, in Van Hoorn, Notulen, Folio 108b and and 113b, NA Invnr. 319, unf.

164 hadden noit gedagt dat wy Makassar tot sulken vernedringe souden hebben konnen brengen dat hy tot het aangaan van sulcken disreputatien en nadeligen contract, in genoegsame submissie soude hebben konnen verstaan, Patriase letter, May 9, 1669, Van Hoorn, Notulen fol. 113b. NA Invnr. 319, unf.
} 
Bongaya treaty ${ }^{165}$. This chronology would explain why the first one reflects the same kind of worries about the final outcome as the letter of August 22, 1668, whereas the second entry signals unrestricted joy over final victory with no remarks of caution.

\section{The nature of the Directors' advice on approach towards Makassar in the particular patriase letters}

Speelman's was praised for his outstanding performance in the middle of the dehumanising effects of war, a war which he had brought to a happy conclusion by his vigilance, dedicated effort and bravery. ${ }^{166}$ Still it remains a fact that the jubilant reaction in the May 9 letter forms the exception to the rule. The Directors' advice on diplomacy towards Makassar generally conveys a message to tread lightly and above all to seek to avoid or to end wars at the earliest possible moment. In this regard the advice in the particular patriase letters falls in line with the model of pragmatic approach in the Directors' General Instructions.

\section{Chapter conclusion}

Strictly speaking, the "Patriase model of overseas diplomacy" in the General Instructions issued between 1609 and 1650 can hardly be called a "model" at all, if by "model" we mean an explicit set of general principles from which are deducted more elaborately defined rules. Advice on diplomacy there was, but the process of formulating advice was not a deductive one, it was an inductive one. The predominant body of advice on diplomatic performance offered by the Directors reflected a pragmatic approach by which a recommended line of action was suggested, where the actual implementation of it to a large degree was put in the hands of the Company's authorities in Asia. From time to time, the Directors' particular advice would slide into more general reflections, but the point of departure was in the final instance case-bound. In other words, the Directors' "model" of overseas diplomacy must be reconstructed from this

\footnotetext{
165 See chapter 8.

166 de chandelycke, en mensch verslindende oorlogh..., de vigilantie, en onvermoeylycken arbeit, voort dapperheyt en goede conduite den E. Cornelis Speelman ... Patriase letter, May 9, 1669, Van Hoorn, Notulen fol. 113b. NA Invnr. 319, unf.
} 
bundle of practical advice and general elaborations originating in specific cases.

Three characteristics of this "model-in-the-making" stand out: the way by which it testifies to a general pragmatic approach towards overseas diplomacy at the outset; how appeals to take a pragmatic stand were implied or explicitly inscribed in the texts of the Instructions; and an inherent drive to acquire as precise information about local conditions as possible. To assume that principles of international law directed the Company's overseas diplomacy is misguided at best. The evidence in the General Instructions, as well as the in the Directors' particular advice on Makassar suggest that their approach towards overseas diplomacy was neither Eurocentric, nor legally dogmatic, but culturally sensitive and inter-culturally pragmatic. 


\section{4}

\section{Culture and Treaty:}

Leonard Andaya's model of conflicting treaty

\section{conceptions and the June 26,} 1637 treaty between Sultan

\section{Alauddin and the Company}

In this chapter, I shall discuss Andaya's propositions about the cultural bias and incommensurability of treaty conceptions using the Company's treaty with South-Sulawesi of June 26, 1637 as my case.

The background before Van Diemen's expedition to the Moluccas 1637 was that after kapitan Hitu had approached Makassar in 1633, and because of Dutch counter actions in the following year, by 1636 almost the entire land of Hitu had risen against the Dutch. ${ }^{1}$ Also the Christian population of Ambon had started protesting the increasing burden of services (Herendienst) demanded by the Company. ${ }^{2}$

In addition, on western Java war with Banten had broken out in November 1633, but negotiations for settlement were opened in March 1636 and a truce signed between the Sultanate and the Company. ${ }^{3}$ Van Diemen's expedition, in

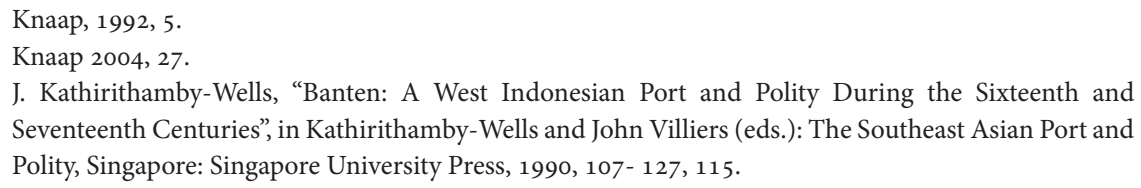
Seventeenth Centuries", in Kathirithamby-Wells and John Villiers (eds.): The Southeast Asian Port and Polity, Singapore: Singapore University Press, 1990, 107- 127, 115. 
other words, took place at a time when Makassar was continually expanding ${ }^{4}$, and the Company was under pressure both in the Eastern archipelago and on Java.

\section{Section 1: Presentation of the June 26, 1637 treaty of peace between the Company and Makassar}

In conjunction with his 1637 campaign against the rebels in Ambon, ${ }^{5}$ Governor-General Van Diemen anchored in the roadstead of Makassar on June 22 with the aim of concluding a treaty of peace and friendship. After four days of intricate negotiations, the Company and Sultan Alauddin of Makassar concluded a peace treaty. ${ }^{6}$

The 1637 treaty was primarily a political treaty. Of the twelve regulations only one dealt directly with bilateral trade between the Company and Makassar. ${ }^{7}$ The other eleven banned Makassarese residents from sailing to Malacca and Ceram, ${ }^{8}$ outlined rules of conduct and responsibility regarding conflict between the Company and other European nations in Makassarese waters, ${ }^{9}$ and regulated bilateral political interactions between the Company and Makassar ${ }^{10}$. The rest of the clauses concerned miscellaneous practical issues such as the reciprocal obligation to hand over runaways, ${ }^{11}$ and the reciprocal recognition of the freedom to practise one's religion. ${ }^{12}$ All in all, then, regulation of political interaction-bilateral as well as with third parties-were the dominant issues in the June 26, 1637 treaty.

\section{Background and context of June 1637 treaty}

The immediate background of the 1637 treaty was Van Diemen's expedition to Ambon and the Moluccas. The raison dêtre of the treaty was to stop the

D. K. Basset, «English Trade in Celebes, 1613-1677", Journal of the Malaysian Branch of the Royal Asiatic Society, 31/1 1958, 1-39, 10-11.

See "section 1", chapter 1.

1637 treaty, Corpus Diplomaticum, 1.303-306.

Specified rates of export tolls to be paid to the Sultan, 1637 treaty, Corpus Diplomaticum, 1.304-305.

1637 treaty, Corpus Diplomaticum, 1.304 .

1637 treaty, unnumbered arts. 4-5 and 7-9, Corpus Diplomaticum, 1.304.

1637 treaty, unnumbered arts. 1-3, Corpus Diplomaticum, 1.303-304.

1637 treaty, unnumbered art. 11, Corpus Diplomaticum, 1.305.

1637 treaty, unnumbered art. 12, Corpus Diplomaticum, 1.305. Both standard VOC treaty regulations. 
"smuggling" of cloves from the Eastern Archipelago via Makassar. ${ }^{13}$ In other words, the 1637 treaty was a political device intended to protect the Company's monopoly rights. It reflected a conflict of interest between Makassar and the Company, as the Makassarese profited both from their sultanate's position as an entrepôt as well as its collaboration with non-VOC Europeans at its roadstead. To stop or at least lessen this, the Company would have to establish a lodge in Makassar, which became an issue during the negotiations. ${ }^{14}$

\section{The nature of the 1637 treaty: Historiographic positions and my propositions}

One important feature of the 1637 treaty is that some of the articles in the final text were proposed by Sultan Alauddin. ${ }^{15}$ Heeres, for instance, points to the final ordering of the respective articles as coming from the Makassarese. ${ }^{16}$ Andaya, on the other hand, sees it as a predominantly European kind of treaty, although with some distinctive South Sulawesi imprints. ${ }^{17}$ Neither one, and in particular Andaya, analyses the treaty as the result of a dynamic process of give-and-take.

What I aim to demonstrate in this chapter is that the 1637 treaty in fact represented a product of negotiated compromises between competing interests. Contrary to Andaya, I also claim that there was "real" communication between the two negotiating parties in the sense that they both had a realistic grip on the issues at hand and that they understood each other's positions. In short, they were negotiating within a shared conceptual framework.

The negotiations and final formulation of the terms of the 1637 treaty was thus a result of a tug of war in which both parties demonstrated a functional understanding of the other's intention and motives. The nature of the 1637 treaty as a negotiated compromise between antagonistic secular interests that presupposed a kind of functional communication is symptomatically lost in Andaya's structural approach.

13 For the background, see Menno Witteveen, Antonie van Diemen: De opkomst van de VOC in Azië (Amsterdam: Amsterdam University Press, 2001), 215-19.

14 For the negotiations on the issue, see section 2; for the formulation of the compromise reached, see section 3 .

15 See sections 2 and 3 , below.

16 Corpus Diplomaticum, 1.304n1, referring to Van Diemen's report, DRB June 22-26, 1637, 286.

17 Andaya, “Treaty Conceptions and Misconceptions," 289. 


\section{Plan of exposition}

The analysis has three main sections. In the first, I discuss Andaya's general argument about the cultural collision between European and South Sulawesian treaty concepts and his views on the 1637 treaty in particular. In the second, I analyse what actually took place during the negotiations leading up to the treaty, with a focus on the nature of the issues and the exchanges that led to the compromises accepted by both parties. In the third, I analyse the formulations of the regulations agreed to in the 1637 treaty, arguing that both the substance of the issues and the formulation of them demonstrate a shared ground of understanding in the Company-Makassar treaty making at the time. The negotiations and final text of the treaty reflect pragmatism on both sides as they struggled to advance and protect their respective secular interests.

\section{Sources}

The analysis mainly rests on the VOC sources, namely Van Diemen's report on the negotiations in Makassar June 24-26, $1637,{ }^{18}$ and Heeres' edition of the 1637 treaty. ${ }^{19}$

\section{Section 2: Perspective in South-Sulawesian thinking on diplomacy and treaty: Andaya's positions and my counter-propositions}

\section{Andaya's structural approach to overseas treaty making}

For Leonard Andaya, the treaty making between the Company and Makassar in general represented a continuous miscommunication as the expectations and concepts of the two parties sprang from a "fundamental difference in cultural attitudes," ${ }^{20}$ or incompatible mental frameworks. Whereas the South Sulawesi treaty was situated in a "spiritual" conception of treaty, and concerned exchanges of spiritual power, the Company's perceptions and beliefs sprang from a

\footnotetext{
18 "Verhaell vant gene d'Heer Generaall van Diemmen wedervaren is zijne Amboijnesche voijage int weder keeren voor Makassar." DRB June 22-26, 1637, 280-89. 
European, rational- legalistic framework, ${ }^{21}$ and concerned specific regulations on trade. ${ }^{22}$ This meant that the very process of treaty making between the two took place between two parties with diametrically opposing intentions and pursuits.

Stemming from antagonistic and deeply embedded cultural perceptions and expectations, the mutual misunderstandings between the Company's servants and South Sulawesi states constituted a constant feature and caused endemic friction and eventually ended in war between the two: "treaties between the Company and a South Sulawesi state were characterised by conflicting expectations, leading to frustration, then mutual recriminations, and finally war." ${ }^{23}$

This friction was present from the first treaties with the Company in the early seventeenth century and persisted well into the colonial period. ${ }^{24}$ Still Andaya does find some local imprints in the Company- Makassarese treaty record, which raises the question of how and why these were included.

\section{Local imprints in the Company-Makassar treaty record}

Andaya points to instances of local influence in some of the treaties between the Company and Makassar, especially in the 1655 treaty, ${ }^{25}$ but also in the 1637 treaty. I shall analyse his propositions on this point in some detail, and will argue that these imprints were less culturally and more contextually embedded than Andaya assumes. If so, none of these local imprints would have been unintelligible to the Company's negotiators.

Andaya claims that: "There is little indication that any effort was made to understand the whole intent of local treaties. Almost the entire corpus of the treaties between the Company and the South Sulawesi states was framed in the Western European tradition of treaty making, with little or no attempt to accommodate local practices." ${ }^{26}$

I reject this on two grounds. First, the 1637 treaty basically focuses on the regulation of specific, concrete issues that were not formulated in Western legal parlance. Second, the Makassarese did not meet the Company's demands by retreating to their local practices or modes of thinking. Therefore, the Dutch

\footnotetext{
21 Ibid. 286, 288.

22 Ibid. 288.

23 Ibid. 291.

24 Ibid. 291.

25 Ibid. 287.

26 Ibid. 286-87.
} 
did not need to familiarise themselves with deep-seated cultural conceptions, as these were not particularly relevant in the Makassarese dealings with a European company. What the Dutch needed to understand was the tactical intent behind the Makassarese suggestions and proposed revisions, as secular interests were primary concerns in these, too. In other words, I shall be arguing that a more contextual and secular interpretation of the Makassarese actions and their meaning might be as plausible as Andaya's structural cultural interpretation.

\section{Andaya on the protection of sovereignty as a "typical South Sulawesian feature," and its imprint on the 1637 treaty}

One imprint of the typical South Sulawesi conception of the protection of sovereignty in the 1637 treaty was, according to Andaya, that it "forbade the Dutch from continuing their hostilities against the enemies in the lands and seas belonging to the ruler of Goa, and explicitly stated that the enemies of one would not become the enemies of the other." ${ }^{27}$ This regulation "asserted the sovereignty and power of Goa in the traditional fashion." ${ }^{28}$ The key qualification is "in the traditional fashion."

At the outset, it is hard to accept that concern about autonomy by itself was peculiar to South Sulawesians. Just a brief look at early modern European history suggests otherwise. ${ }^{29}$ But Andaya's argument for a dichotomy between European and South Sulawesian conceptions of "autonomy" is based on a proposition of an absolute difference in meaning, nature, and intent in the pursuit of "sovereignty." This kind of conceptual antagonism is what caused the mutual misconceptions. Andaya's line of argument is based on his proposition about the spiritual conception of ruler-lineage-state and treaty in South Sulawesi..$^{30}$ Two questions arise. First, if, for the sake of argument, we accept Andaya's assumptions, how incomprehensible would the South Sulawesian conceptions have been to Europeans, who at least shared the historical experience of contests over sovereignty? And, second, why would the Makassarese apply their local tradition in disputes with

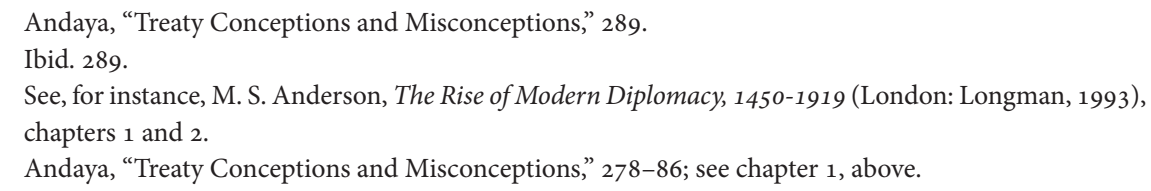


an outsider party like a European company? Only one response is possible to the latter question: they were "culturally blindfolded" and thus unable to apply an alternative set of thoughts and actions. I reject both the assumption of incompatibility and the proposition of "cultural block."

\section{Problems in the analysis}

Andaya's structural line of argumentation for one presupposes that when dealing with Europeans, Alauddin in the 1637 case, and his successors in negotiating for the other treaties, were unable to switch their approach to negotiation from a fixed local mode. But how sure can we be that the Makassarese considered their dealings with the Dutch from a "metaphysical" or "spiritual" point of view, and did not apply a more "realist," secular approach in these cases, which definitely did not form part of the internal South Sulawesian hierarchy of power? Secondly, Andaya does not take into account the existence of a category for state interaction particularly designed for outsiders, pointed out by Resink and others.

Speaking for the realist alterative as the relevant interpretation key for the 1637 negotiation is that power relations in the secular sense were a preoccupation for the Makassarese during the treaty negotiations. ${ }^{31}$ Furthermore, if we assume that the pragmatic model of diplomacy that, as we have seen, underlay the Directors' General Instructions already in 1609, constituted a norm, how plausible is it that the Company's servants overseas, and an experienced one like Van Diemen at that, would stick to a blueprint of European concepts and procedures of treaty making in their overseas practice?

Lastly, there is a comparative argument that undermines Andaya's insistence on incommensurability. Let us again accept that conceptions, practices, and institutions of diplomacy differed in early modern Europe and Southeast Asia. The key question remains whether such differences made for systematic miscommunication. As for Andaya's example of “sovereignty," I do not think there was. Sovereignty issues in their general form-that is autonomy of territorial decision making - represented a type of conflict that was well known in both Europe and Southeast Asia. So, there are a number of reasons why we should not at the outset accept that Alauddin and the Dutch negotiators were caught in a game of mutual misunderstanding.

31 See section 2, below. 
Nor should we assume that the treaty itself contained two distinct and separate parts, one Eurocentric treaty blueprint and one typical South Sulawesian component. If there was a kind of mutual understanding and haggling over conflicts over shared issues, the miscellaneous regulations might just as well be seen as products of compromise on secular issues with differences in the colouration of meaning, but nonetheless mutually comprehensible.

My own proposition is that such was the case in this instance: The 1637 treaty represented a negotiated compromise between actors who did communicate with each other in a meaningful way, and the resulted compromise entailed a mix of concessions and wins on both sides.

\section{Alauddin's claim of perceptions of perpetuity as typical of the South Sulawesi treaty tradition}

When Sultan Alauddin insisted that the 1637 treaty was binding not only for the present, but for future governors-general,,$^{32}$ Andaya holds that this represents another local cultural imprint of the South Sulawesi conception of treaty "in conformity to local practices." 33 What it conforms to is that in the South Sulawesian tradition a treaty was never seen as being terminated, but existed for perpetuity: "Once a treaty had been agreed upon it remained a permanent agreement which could be resurrected and renewed or allowed to recede into the background in the face of other superior political and spiritual force. The enduring sacred documents were made once and for all." ${ }^{34}$

So, according to Andaya, the perpetuity claim in the 1637 treaty originated from the South Sulawesi tradition even if it was presented "in the form of a European treaty. ${ }^{35}$ It entails two alternative assumptions. It might mean that the Makassarese really wanted to integrate the VOC into the South Sulawesian political and spiritual hierarchy, although this is contradicted by the Makassarese stand during the negotiations. ${ }^{36}$ Alternatively, it might mean that the Makassarese were mentally or culturally incapable of applying any approach other than the local model, although they were dealing with an outsider. The latter is Andayas position.

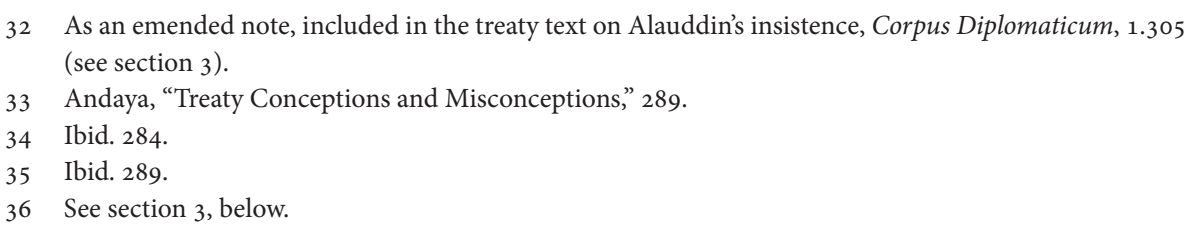


As for the possibility of Makassarese familiarity with the European treaty tradition, Andaya holds that they could not have gained any knowledge or experience in European treaty making from the Portuguese, as there simply is no evidence of any treaty making with them. ${ }^{37}$ The VOC treaties of 1637,1655 , and 1660 represent the only occasions in which Makassar entered into a formal treaty arrangement with a European power..$^{38}$ The Makassarese, according to Andaya, then entered into all these negotiations equipped only with their local conceptions. The proposition rejects cultural dynamics in response to novel contextual challenges. It represents another assumption that I reject on grounds of the Makassarese negotiation performance.

\section{Antagonistic notions of "breach of contract"}

One consequence of the divergent meanings of the perpetuity of a treaty in the European and South Sulawesian traditions is that the notion of "breach of contract" did not really exist in the South Sulawesian tradition. Whereas in the European sense breach of contract was conceived as specific actions that ran contrary to specific terms in the treaty, the South Sulawesian conception of treaty allowed for shifts in alliances reflecting changes in the real world without considering such shifts a breach of prior treaties. The treaties were still considered valid, as an integral part of the realm's living tradition. When actual power centres changed and old alliances were broken and new ones formed, the de facto obsolete treaties fell into the shadow of the new ones, but always with the possibility of reactivation should further changes in power relations or spiritual prestige require it: "Once a treaty had been agreed upon, it remained a permanent agreement which could be resurrected and renewed or allowed to recede into the background in face of other superior political and spiritual forces." ${ }^{39}$

The notion of the treaties as "enduring sacred documents" 40 was no impediment against stability or dynamic readjustments. Quite the contrary: it facilitated both: "The treaties, oaths and the whole treaty making procedure were part of a continuing process of reassessment of political and spiritual affiliations to

37 Andaya, “Treaty Conceptions and Misconceptions," 289.
38 Ibid. 289.
39 Ibid. 284.
$40 \quad$ Ibid. 284. 
assure the establishment of a hierarchy of states which accurately reflected the power situation in South Sulawesi." ${ }^{41}$

On this background Andaya ranks the South Sulawesi states' diplomatic interactions as superior to that of Europeans or the Company in this regard, the latter representing a use of treaties as "instruments of oppression," 42 the former "a means of establishing proper and peaceful relations." 43

Leaving the moral contest aside, the problem with Andaya's contrast here, as in the above, is that it rests upon the assumption that the Makassarese would apply their local conceptions and norms of treaty making in their dealings with a non-local, outside party that was not an integrated part of the South Sulawesian hierarchy.

The convention of insisting on the perpetuity of the treaty, in the sense of "enduring" (eeuwige), was an integral component of the Company's contractual repertoire. The phrase functioned as a formal guard against breaches of contract. If in concluding the treaty Alauddin felt that he had got the best terms he could, all things considered, his insistence on perpetuity might just as easily be explained by contextual factors as by cultural ones. He might, in fact, have had every reason to have the final treaty confirmed as a fixed agreement.

\section{Implications of unnumbered articles}

Andaya points out that the typical form for a Company (and by extension the typical "Western European") treaty was to number the treaty clauses and reserve one single issue for each respective article. ${ }^{44}$ This convention runs counter to South Sulawesian conceptions of "treaty." "The local states viewed the treaty not in its individual parts, but as a total document," he writes, and where "the treaty represented an open declaration of a shift in the spiritual and political power relationships in the area." 45 The difference between numbering and not numbering for Andaya springs from the antagonism between the "treaty" conceived of as a list of specific agreements in the European tradition, as opposed to a general act of symbolic bonding in the South

\footnotetext{
Ibid. 284 .

Ibid. 284 .

Ibid. 284 .

Ibid. 287 .

Ibid. 288 .
} 
Sulawesian tradition. In the latter, the nature of the relationship between the treating parties was already regulated in the implications of the preamble. There was no need for explicating specific regulations at all; they were already implicitly stated. ${ }^{46}$

The regulations of the 1637 treaty are not numbered, and the absence of numbering could then be taken as a Company concession to South Sulawesian tradition. But to conclude that is simply wrong. The treaty clauses, although not numbered, are all one-issue regulations, starting with "that" - twelve in all. Moreover, as we shall see, there is a consistent logic in the chronology of the unnumbered clauses. So, disregarding the absence of formal numbering, the treaty is, in Andaya's view, a typical Western treaty. By implication, it should therefore be "foreign" to Alauddin in the sense that it was culturally incomprehensible. Again, the counter-argument can be made that several of the specific points were raised by Alauddin himself, and the final formulation of these points came about as results of revisions proposed by Alauddin. ${ }^{47}$ So, even if the Dutch treaty proposal differed compared to those found in the local South Sulawesian tradition, it was neither incomprehensible nor incompatible with it, at least not to a degree that prevented Alauddin from formulating changes to defend his interests. Alauddin's negotiation performance does not conform to an assumption about his ignorance of what was going on.

\section{The swearing ritual as an example of local imprint}

A final example of a local trait from South Sulawesian treaty making was the mode of swearing on it. Here, Andaya points to the ritual drinking of palm wine stirred with a kris, and taking an oath on the Koran. ${ }^{48}$ In the case of the 1637 treaty, no such ritual took place. The signing of the treaty by both parties was accompanied by a conventional exchange of gifts. ${ }^{49}$ Should we take this to mean that the Company overran the Makassarese with their own secular mode of ritual confirmation of treaty? Two arguments speak against this: First, there is no reason to assume that Alauddin would want the Company to take part in a Sulawesian ritual of oath taking, as it would imply that the Company was

\footnotetext{
46 Ibid. $280-81$.

47 See sections 2 and 3 below.

48 Andaya, "Treaty Conceptions and Misconceptions," 287.

49 Van Diemen's Report, DRB June 22-26, 1637, 289-90.
} 
being integrated into the South Sulawesian hierarchy of states. His behaviour during the negotiations clearly indicates that he was striving to minimise the Company's presence and influence. ${ }^{50}$ As for the Company, its representatives might well have agreed to such an act, because allowing the locals to swear according to their local practices was an established Company practice. This concession may have represented no more and no less than an implementation of the advice from the home country to accommodate local practices.

\section{Section conclusion}

The examples that Andaya gives of local imprints in the 1637 treaty do not shake his conviction that it represented a European type of treaty. Following Andaya's assumption of mutually incompatible conceptions regarding contracts, the negotiations represented a miscommunication between the Company negotiators and the Makassarese. Seen from the South Sulawesi side, the specific regulations in the Company's proposed treaty were regarded as unimportant, and their implications were not fully understood by the Makassarese. This proposition assumes that both parties were "prisoners" of their respective traditions, which blocked functional communication.

Illustrative of this view is that as late as the Bongaya Treaty, Andaya holds that the Company and Makassar "differed fundamentally in the manner they invoked the treaty as a legitimizing document." ${ }^{11}$ Even in the post-Bongaya period, there were conflicts between the Company and the South Sulawesian states: "except for certain exceptions, the difficulties stemmed basically from the conflicting South Sulawesi and European conceptions of treaties and treaty-making." ${ }^{52}$ As for the exceptions, specifically those instances in which the Company gave concessions to local practice, as in the 1655 treaty, it did so because of its weak bargaining position, or because the treating parties were themselves of minor importance to the VOC. ${ }^{53}$

Andaya concedes then that the Company's negotiators were neither unaware nor totally ignorant of the local mode of local treaty making. ${ }^{54}$ But the

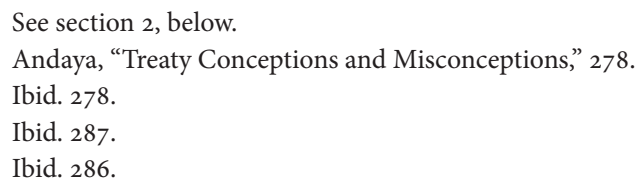


model they generally applied in their own treaty making was generally "framed in the Western European tradition of treaty-making with little or no attempt to accommodate local practices." ${ }^{55}$ Makassar, however, did not adopt "the content or intent of the European treaty" in the contracts of either 1637 or $1655 .{ }^{56}$ The evidence of the negotiations for and the final text of the June 26 treaty strongly suggests otherwise, both for the Company's as well as the Makassarese understanding of its partner's respective motives and modes.

\section{Section 3: The significance of communicative performance in the treaty negotiations}

\section{Brief chronology of events from June 22-June 26 and their implications}

The events from the arrival of Van Diemen's fleet outside the roadstead of Makassar on June 22 and up to the signing of the treaty on June 26 can be split into two main phases. From June 23 to the afternoon of the 24 th was spent on establishing contact with Alauddin, and seeking out his position on entering into a treaty with the Company. Having received an affirmative reply about this (via middlemen), the Company's conditions for the treaty were presented to the Makassarese envoys on June 24. This was the start of the real negotiations. All that happened from then on followed a pattern in which the Dutch presented conditions and propositions for the treaty, which were reviewed by Alauddin and members of his court. In this process, the sultan came up with revisions and amendments, which in their turn were reviewed jointly by the Company's chief negotiators, Anthony Caen and Van Diemen, aboard ship. Caen would then return to shore with the revised propositions, which again were reviewed by Alauddin. This "ping-pong" game of treaty bargaining took place June 24-26. I shall analyse both phases in detail.

\section{Section propositions}

My proposition is that the conclusion of a treaty between Sultan Alauddin and the Company on June 26 was the result of a process of actors communicating

55 Ibid. 288.
56 Ibid. 289. 
and bargaining within a shared framework of conceptions. This was so because the treaty communication was determined neither by European conceptions brought from overseas by the Company nor the Makassarese acting from genuinely South Sulawesian conceptions. The negotiations took place in a mutual understanding of the issues and their implications for both parties. This interpretation finds corroboration in the actual chronology of events from the time Van Diemen anchored outside the roadstead of Makassar up to and including the signing ceremony.

\section{Events of June 22: Determining the sultan's intentions}

On June 22, Van Diemen's fleet anchored off Makassar. The first observations noted were an Achenese vessel in the roadstead, the flags of the English and Danish lodges inside the city, and more significant, five "blood flags" flying from various Makassarese fortifications. ${ }^{57}$ Van Diemen deliberated with his next in command, Anthony Caen, and a decision was made to show signs of their peaceful intentions. ${ }^{58} \mathrm{~A}$ white flag was hoisted and a salute of five cannon shots given. The Makassarese response was to lower their flags, but no salute was given. During the evening, however, the Dutch noticed that the guard on the beach had been strengthened. ${ }^{59}$

This ambiguity of this response must have fitted well with the Dutch expectations. When arriving at Makassar, Van Diemen did not know whether to expect hostile actions or a willingness to negotiate. So far, Van Diemen and Alauddin could be said to have behaved like dogs meeting not yet knowing whether to bark, bite or wag their tails.

\section{Events of June 23: The Achenese ambassadors as communication link and mediators}

\section{Morning June 23}

Two immediate tasks presented themselves after the first encounter June 22, namely to find out Alauddin's intentions and if they were friendly, determine how to establish a communication channel with him. As it

57 Van Diemen's Report, DRB June 22, 1637, 280.

58 Van Diemen's Report, DRB June 22, 1637, 281.

59 Van Diemen's Report, DRB June 22, 1637, 281. 
turned out, both tasks were solved with the assistance of the Achenese anchored at the roadstead. As no Makassarese vessel had approached the Dutch by the following morning, a decision was made at the ship's council to launch a smaller vessel, carrying a white flag to approach the Achenese in order to get information about the state of affairs in Makassar and to see if the Achenese would be willing to act as go- betweens and bring a message of the Company's intentions of peace to Alauddin. ${ }^{60}$ The Dutch got almost more than they could have hoped for. After half an hour, the sloop returned carrying four Achenese with it. These Achenese had been serving as envoys to Alauddin, and so they volunteered to act as messengers to him for the Company. ${ }^{61}$

Their report on Alauddin's feelings concerning the arrival of the Dutch explained both the ambiguous actions the evening before as well as the absence of any vessels to greet them that morning. According to the Achenese envoys, Alauddin was fearful of Dutch intentions and had forbidden any ship to approach the Dutch vessels. Furthermore, Makassar had recently been hit by a plague with a death toll of a "hundred thousand," obviously implying that the Company had arrived at a difficult time in Makassar. ${ }^{62}$ From the Dutch point of view, this might seem an opportune time to strike a deal.

Having in any case cleared up the reasons for the absence of any Makassarese initiatives for contact so far, as well as having acquired a clearer indication of Alauddin's situation, it was time for the Dutch to act. Van Diemen asked the Achenese to inform the sultan that the Dutch had come with peaceful intentions, and therefore wanted to send envoys ashore. For this to take place, the sultan must indicate his intentions for peace by hoisting a white flag as the Dutch had done. ${ }^{63}$ The Achenese agreed to act as middlemen conveying the message to the sultan. The Achenese were then brought back to their own ship, alongside which came a Makassarese longboat. ${ }^{64}$ Having been informed about the Achenese talks with the Dutch, the Makassarese longboat returned to shore. Before long, another Makassarese boat set out for the Achenese vessel, presumably carrying Alauddin's response to the Dutch initiative. After another Makassarese visit to

\footnotetext{
60 Van Diemen's Report, DRB June 22, 1637, 281.

61 Van Diemen's Report, DRB June 22, 1637, 281.

62 Van Diemen's Report, DRB June 22, 1637, 281.

63 Van Diemen's Report, DRB June 22, 1637, 281.

64 “duijsentbeen." Van Diemen's Report, DRB June 22, 1637, 281.
} 
the Achenese, it was reported to Van Diemen that Alauddin's response to the Dutch overture was that he himself was inclined towards peace, and that he had expected Dutch envoys to come ashore the day before. Not long after that, the Dutch saw a big white flag flying at the main Makassarese fort. ${ }^{65}$

It is worth noticing that up to and including the hoisting of the flag of peace, all communications between the Company and Alauddin had been either by signals or via third parties. I take this as indicative of both Van Diemen's and Alauddin's doubts about each other's intentions at the time. It seems plausible to argue that had it not been for the Achenese middlemen, the whole communication could be viewed as "dumb barter" diplomacy.

With the Makassarese hoisting of a white flag, the next step was to prepare for direct negotiations. As it turned out, these were a no less complicated affair than establishing communications had been. The negotiations were characterised not so much by misunderstandings springing from cultural incompatibility as by mutual suspicion of each other's intentions and motives, and by conflicting interests.

\section{Negotiating for negotiations, June 23}

With the goodwill sign given by Alauddin, around noon a five-man Dutch delegation, including a "halberdier" and a trumpeter, was sent ashore to establish a procedure for the negotiations. ${ }^{66}$ Besides again declaring the Company's desire for peace, the Dutch proposition was that the sultan should send envoys to the governor-general's ships the following day, to have the Company's intention for peace verified and hear its initial conditions. As security, the Dutch would offer hostages to be held ashore while the negotiations aboard ship were going on.

The Dutch mission was received by Sultan Alauddin, his father, and nobles of the realm. The Dutch delegation placed themselves with legs crossed "according to the customs of the land." ${ }^{67}$ They then observed while Alauddin read their letter and conferred and deliberated with his father, the prince of Tello, and other nobles. Alauddin's response was clear: He declared himself in favour of a peace, and added that he would send two of his ambassadors to the

\footnotetext{
65 Van Diemen's Report, DRB June 22, 1637, 281.

66 Van Diemen's Report, DRB June 22, 1637, 282.

67 Van Diemen's Report, DRB June 22, 1637, 281.
} 
Company's ship as requested. As a gesture of his good intentions, the offer of hostages was declined. Two of the sultan's envoys were then sent to the ship in the company of the Dutch delegation for preparatory talks concerning the negotiations of the treaty.

\section{Initial negotiations on board the ship, June 23}

When Alauddin's two envoys boarded the Company's ship around five in the afternoon, it had already been decided that Anthonie Caen, being fluent in Malay should do the talking. ${ }^{68}$ "Having now (at last) entered into communication," as Van Diemen comments, ${ }^{69}$ Caen explained the Dutch objectives in coming to Makassar. First, the Dutch fleet intended to attack two Spanish galleons that were believed to have sought refuge in Makassar, but as that information had proven to be false, this point was withdrawn for the time being. ${ }^{70}$

The plan to attack the Spanish galleons at the Makassar roadstead clearly presupposed the sultan's acceptance of the Dutch waging war against their enemies in Makassarese waters. Whether aware of it or not, it is clear that Caen's opening statement in the preliminary talks entailed a position that could be taken as a provocation by Alauddin. That it was a delicate issue can clearly be seen from the wording about this in the final treaty. ${ }^{71}$ Although the matter was dropped in this first meeting, a controversial issue had been raised, namely the Company's right to pursue its enemies in Makassarese waters, and the issue was to reappear in succeeding sessions. Although he did not press the point any further in this first meeting, Caen went on to explain the second objective of the Dutch presence, namely to conclude a treaty of "peace and friendship" 72 with the sultan. He then listed the Company's conditions for such a peace.

It is noteworthy that the Company's initial intentions were presented as not only seeking a treaty of peace, but one of peace and friendship. In standard VOC diplomatic terminology, that meant treaty of alliance. What the Company in the final end got was a peace treaty. ${ }^{73}$ One article in the final draft declared a bond

\footnotetext{
68 Van Diemen's Report, DRB June 22, 1637, 283.

69 “dat nu in passant comende." Van Diemen's Report, DRB June 22, 1637, 283.

70 Van Diemen's Report, DRB June 22, 1637, 283.

71 The issue was more generally covered but modified in the final treaty text. See 1637 treaty, unnumbered art. 7, Corpus Diplomaticum, 1.304. See also section 3, below.

72 “vreede ende ende vruntschap." Van Diemen's Report, DRB June 23, 1637, 283.

73 The title of the 1637 treaty began "Condition for peace..." 1637 treaty, Corpus Diplomaticum, 1.303.
} 
of alliance in the sense that both parties obligated themselves not to conspire with the other party's declared enemies, and if that one was attacked by such, the other would come to their aid. ${ }^{74}$ There is a telling insertion of praise for the unique qualities of the Company as an alliance partner in this clause, possibly with an implicit threat against those who would choose to side with the Company's enemies, however, "keeping in mind that the Dutch would always feel obligated to protect their allies from all unreasonable actions." 75 Still, what the Company got in the end from Makassar was less than what they initially hoped for.

Regarding the Company's conditions for the peace, the only one presented by Caen at the preliminary meeting of June 23 was that the sultan should not allow his subjects to trade in "enemy places" such as Malacca and the coast of Ceram. ${ }^{76}$ The condition is easy to explain from the Company's point of view; it was intended to prevent the "smuggling" of cloves. But the condition also had further political implications for the relationship between the Company and Makassar. Because of its close connection with the Portuguese and the vital role of the Portuguese community in Makassar's commercial life, Alauddin could hardly afford to side openly with the Company against them. But this is clearly what the Dutch expected. As we shall see, Alauddin solved this issue in the final treaty by allowing the Company to pursue their aims in this matter, but at the same time diminishing his own responsibility by leaving the enforcement of the sailing ban exclusively to the Company, while simultaneously forbidding the Company to pursue their enemies in Makassar roadstead. ${ }^{77}$

The demand for sailing restrictions concluded Caen's list of the Company's conditions for a treaty. Caen then went on to discuss the procedure for further negotiations. If the Dutch conditions were accepted, the Dutch proposition was that negotiations should take place the following morning. The proposed procedure was that Alauddin should notify the Dutch, who would then send "competent persons and an honourable delegation"78 to "conclude the peace in the appropriate manner." 79 The two Makassarese envoys then took leave with

1637 treaty, unnumbered art. 8, Corpus Diplomaticum, 1.304; see analysis in section 3.

"Behoudens dat de Nederlanders t'allen tijde haere geallieerde tegens onbehoorlijcke overlast moeten protegeren." 1637 treaty, unnumbered art. 8, Corpus Diplomaticum, 1.304; see section 3.

76 Van Diemen, Report, DRB June 23, 1637, 283.

771637 treaty, unnumbered arts. 3 and 6, Corpus Diplomaticum, 1.304.

78 "Een ander gequalificeert person ende aensinnelijcke swiette." Van Diemen's report, DRB June 23, 1637,283 .

79 "om den vreede in behoorlycke forme te sluiten." Van Diemen's report, DRB June 23, 1637, 283. 
the letter in which the Dutch declared their intentions and conditions. They promised to return with the sultan's reply the following morning.

What had the Dutch achieved in their second day of negotiations? Quite a lot actually: Not only had they been received with apparent goodwill by the sultan, but they had also entered into direct negotiations and had presented their claims. What, then, were their further expectations for the negotiations to follow? Clearly that the treaty would be agreed on, signed, and sealed the following day! It was not to be that simple, however.

\section{Events of June 24: A simple "misunderstanding"?}

The agreement with Alauddin's two envoys on the afternoon of June 23 was that if Alauddin accepted the Company's conditions, he would give notice the following morning for the Dutch delegation to come ashore to conclude the treaty. But as morning came, there was no sign of messengers from the sultan. Van Diemen then again turned to the Achenese for information as to what was happening. The Achenese explained that the sultan had been waiting for the Dutch to come ashore for quite a while. When informed about the Dutch expectations, Alauddin had declared his intentions and wish for peace, and had been expecting the Company's envoys already the day before. He proposed that the negotiations should proceed as originally suggested by the Dutch. ${ }^{80}$

It is probably indicative of Van Diemen's doubts about the sultan's real intentions that he sent no delegation ashore right away. Instead, it was decided that a message be sent to the sultan to inquire if an audience now was convenient. ${ }^{81}$ Whether this procedure had an ironic element in it is impossible to say, but what is clear is that the letter that this "preliminary" delegation brought with them was not without the implicit reproach of the sultan and a hint of self-righteousness for the Company. Assistant Merchant Van Collster, who led this mission to find out whether Alauddin was ready for negotiations, was instructed to ask the sultan whether he would receive a Dutch delegation because the Dutch "had been waiting for an answer as promised by him." ${ }^{22}$ The sultan met Van Collster in a conciliatory manner. He said that he himself had been waiting quite a while for

\footnotetext{
80 Van Diemen's report, $D R B$ June 23, 1637, 283.

81 Van Diemen's report, DRB June 23, 1637, 284.

82 “conform toesegginge op antwoort was blijven uit te zien Van Diemen's Report." Van Diemen's report, DRB June $23,1637,284$.
} 
the Dutch to appear, and then with a laugh he declared that the blame must be put on a misunderstanding by his envoys. ${ }^{83}$ Van Collster was thereupon brought back to the ship to confirm the sultan's readiness for the audience.

The "misunderstanding" about proper procedure was critical in the sense that if it had not been cleared up, it would have led to an increased lack of trust. And had it escalated, that lack of trust might well have led to a breakdown in negotiations before they even started. Van Diemen's way of handling it was, as we have seen, to suggest that the sultan's side was not upholding its agreements. Alauddin preferred simply to brush the affair aside while at the same time he offered an outstretched hand to the Dutch. Judging by his actions, Alauddin seems to have had a fairly accurate perception of what was at stake at the time. In any case, having thus cleared up the initial misunderstanding, on the morning June 24, the scene was set for "real negotiations," namely an agreement on the specific contents of the treaty.

\section{Negotiations of substance, June 24}

Caen, who had done the initial talking with the Makassarese envoys the day before, was appointed chief negotiator of a six-person delegation, including a trumpeter, all "well-dressed" for the task. Once ashore, the delegation was received with honour and brought to the court to meet with the Makassarese negotiation party: Alauddin himself, and prominent members of the elite. ${ }^{84}$ So, after some delay it was time to determine among members of the Makassarese elite themselves the terms of the treaty.

After giving another concession to protocol by passing on the governorgeneral's greetings to Alauddin, Caen repeated that the purpose of their mission was to negotiate the terms for a formal peace with the sultan. ${ }^{85}$ There seems to be an adjustment here compared to the day before. Caen's proposed treaty of "peace and friendship" of the day before was reduced to "peace" and "peace" only. This might well reflect that Van Diemen and Caen had lowered their expectations in view of the complications they had already experienced in securing a negotiating position.

\footnotetext{
83 “een abuijs van zijn volk.” Van Diemen's report, DRB June 23, 1637, 284.

84 Van Diemen's report, DRB June 23, 1637, 284.

85 "Van de condition die op het sluijten des vrede mocten voorgestelt worden." Van Diemen's report, DRB June 23, 1637, 284. One should note that neither "friendship" nor "alliance" are mentioned.
} 
The Company's initial conditions for peace were also repeated, but they were not phrased in the same manner. On June 24, the demand for a ban on sailing to Malacca was openly stated as being directed against the Portuguese. The sultan should prohibit his subjects from sailing to Malacca and Ceram because the former was in the hands of Company's declared "arch-enemies." It is not inconceivable that the implication of this demand was that if the Makassarese did not comply, the Dutch would consider them enemies, too. Also on the speculative side, it might well be that the explanation of the war against the Portuguese could have been taken as an invitation to Alauddin to take a pro-Dutch stand against the Portuguese. After all, who would want to side with deceivers, unless they be deceivers themselves!

\section{Alauddin's first response, June 24}

After Alauddin had conferred with his suite, prince of Tello acted as spokesman. He declared once more that the sultan "highly applauded the offered peace" ${ }^{87}$ and that he wished "nothing more than to confirm an everlasting treaty" ${ }^{\prime 8}$ This was an exaggeration, to say the least. After the initial gesture of general goodwill, Alauddin, still speaking through prince of Tello, went on to give the Makassarese position on the Dutch proposals in more detail, raising several objections and proposing several revisions.

As for a Dutch prohibition on Makassarese sailing to Malacca and Ceram, the sultan held forth that sailing to those destinations were traditional rights of his people and beneficial to the welfare of his realm. ${ }^{89}$ Still he accepted the prohibition in principle, by recognising the Company's right to enforce the ban in "unfree waters," 90 and that the exercise of rights of sanction should not be regarded as an infringement or breach of contract from the Dutch..$^{91}$ This was

\footnotetext{
86 “openbaere erfvijanden." Van Diemen's report, DRB June 23, 1637, 284.

87 “den aengeboden vrede op't hooghste behaechte." Van Diemen's report, DRB June 23, 1637, 284.

88 "Item niet anders verlanghden alls om deselve te conformeeren ende voor eeuwich te continueeren." Van Diemen's report, DRB June 23, 1637, 284.

89 “Tot beter welvaert van zijn landt souwde exerceeren." Van Diemen's report, DRB June 23, 1637, 285.

90 "Datt wij zijn onderdaenen off subjecten op gemelte onvrij vaarwaetters bejegennende als vijanden aenslaen mochten." Van Diemen's report, DRB June 23, 1637, 285.

91 The grant of the Company's right of sanctions continued thus: "sonder dat het selve eenige verbreckinghe van het selve eenige verbreckinghe aen dese contract veroorsaecken soude." Van Diemen's report, DRB June 23, 1637, 285.
} 
also what was agreed upon in the final treaty. ${ }^{92}$ Although giving in to the Dutch demand, Alauddin did leave his imprint on the regulation of the sailing ban issue. First, he made his statement on the traditional Makassarese sailing rights in the "unfree waters," and although accepting the Company's terms, neither the blame for breaches nor the obligation of enforcement was laid on him. He must have considered it the best he could get given the situation he was in with a Company fleet anchored in his roadstead. Alauddin's recognition of the "persuasive power" of the Company's military strength was explicated both during the negotiations and in the final treaty. ${ }^{93}$

Seen in this light Alauddin seems to have been acting rationally to protect the secular interests of Makassar, in particular its sovereignty and livelihood. When he made concessions, as in the above example, his strategy seems to have been to give away what the Company would very likely take anyway, given their superior naval strength. From such considerations of the asymmetrical balance of military strength it seems reasonable to suggest that Alauddin's thinking went something like the following: If he refused to comply with the Dutch condition, they would act to enforce it anyway, while he himself risked war with the Company. Total compliance, on the other hand, would mean that if he failed to enforce the prohibition, which he in all likelihood would, he would himself be accused of a breach of contract, the likely outcome of which again could be open war.

If we view the Makassarese acceptance of this perspective, it might as likely originate from a shared reason of state rationality between the Makassarese and the Company's negotiators as from a miscommunication between two parties who were unable to transgress their traditional mental framework. It is also well worth noticing that the Dutch demand for a sailing ban was not phrased in legal generalities. The formulation of the regulation was casuistic and concrete. This all suggests that Alauddin and Van Diemen not only were players in the same game, but were able to perceive it as such.

With the Makassarese acceptance of the Company's conditions for peace on June 24, the conditions for a treaty seemed settled. Depending on Dutch approval of the Makassarese revisions, all that remained was the signing and

\footnotetext{
921637 treaty, unnumbered art. 3, Corpus Diplomaticum, 1.304; see section 3.

93 See below, especially section 3 .
} 
sealing of the treaty. ${ }^{94}$ The procedure for the final signing was agreed as follows: On Caen's return to the ship, Van Diemen was to signal as soon as he had accepted the sultan's revisions and signed the treaty. The sultan was then to give his return salute from the fort. ${ }^{95}$ But the final deal was not closed yet. Before he returned to the ships Caen raised the issue of establishing a Company lodge in Makassar. ${ }^{96}$ This raising of an issue of substance after the negotiations proper had been concluded could be regarded as a breach of protocol, but on the other hand, in principle the request should not be regarded as controversial, since the right of permanent residence had already been granted to the Portuguese.

But, from the Makassarese point of view, the request for a permanent Dutch lodge was both controversial and delicate. It put Alauddin in a dilemma, because to reject it outright would be offensive, while conceding to it would put Makassar in an awkward position. A Dutch presence in Makassar would increase the probability of outright violence between the Dutch and other Europeans in the realm itself. More important, it might expose the Makassarese to increased Dutch influence in all their affairs. In that sense, the request for a permanent lodge went to the heart of their concerns over Makassarese autonomy and sovereignty. Alauddin solved the dilemma by replying that an establishment of a Dutch lodge "may well happen, but first they had to come to trade." 97

In the final treaty text Alauddin's vague answer was worked into a compromise: The Company was allowed to establish a lodge, but not on a permanent basis, the right was restricted to periods of stay for Company ships..$^{98}$

Furthermore, the establishment of a Company lodge in Makassar meant that a whole new range of issues, particularly concerning jurisdiction in cases of conflict between Company servants and the sultan's subjects or third parties residing in Makassar, had to be regulated. Such concerns figured either

\footnotetext{
94 Van Diemen's Report, DRB June 24, 1637, 285.

95 Van Diemen's Report, DRB June 24, 1637, 285.

96 "Alls off seer gaerren eenige residenten op Macassar wilde houwen." Van Diemen's Report, DRB June $24,1637,285$.

97 Van Diemen's Report, DRB June 24, 1637, 285.

98 The crucial formulation was "zoo langh hier een off meer schepen ter rheede hebbebde." 1637 treaty, unnumbered art. 1, Corpus Diplomaticum, 1.303-304.
} 
implicitly or explicitly in several of the clauses of the final treaty text.99 The ruling on these political and juridical issues also became a major topic in the negotiations.

\section{Dutch deliberations and swift response on the ship, June 24}

After Alauddin's response on the lodge issue, Caen returned to the ships for deliberations and instructions on how to respond to Alauddin's response. Van Diemen was quick to accept Alauddin's propositions, and ordered the firing of the salute to confirm his signing of the treaty, thirty-two shots in all. "After some waiting," a "counter-salute" was fired from the Makassarese fort, from "three pieces." 100

Van Diemen noted both the imbalance in numbers of shots fired and the interval between the Dutch and Makassarese salutes, which suggests he thought the Makassarese response was asymmetrical. He still may have harboured doubts about Alauddin's real intentions and motives, as he "seems to be totally under the spell of our enemies and feigned friends." 101

On the other hand, there can be no doubt that after receiving Caen's report Van Diemen was convinced that only a few formalities remained before the Company could sign and seal the treaty with Makassar. Nevertheless, the following day, when Van Diemen and Caen originally planned to devote to the concluding formalities, saw another round of negotiations.

\section{Alauddin's amendments and continued negotiations, June 25}

On sending Caen ashore with an "honourable" retinue on the morning of June 25, the Dutch expected Alauddin to sign the treaty agreed to the previous day.

\footnotetext{
991637 treaty, unnumbered arts. 2-3, 5-6, and 11-12. For the negotiations on these issues, see below. For the final formulation of the regulations, see section 3.

100 Van Diemen's Report, DRB June 24, 1637, 285.

101 "Apparent door onse vijanden and geveijnsde vrunden d'ooren voll geblasend wesende." Van Diemen's Report, DRB June 24, 1637, 285.
} 
Instead, Caen was met by several amendments proposed by Alauddin. As these undisputedly represented Makassarese deliberations and a further response to the Dutch proposals of June 24, the sultan's proposals for amendments and his way of putting them forward on June 25 are worth analysing in detail. In them we are faced with an autonomous Makassarese diplomatic response to the Dutch initiative "in the raw."

Alauddin's proposed amendments, written in Malay, were presented as intended "to strengthen the obligations and commitments of the contract for both sides." ${ }^{102}$ Alauddin also repeated his "sincere and sole intention for a lasting peace," 103 and assured that his amendments were "completely in line with what had been agreed to the day before, translated in his presence into the Dutch language." 104 Alauddin requested that the June 24 document with the governor-general's signature be returned, and that his own amendments be included in a new draft of the treaty. ${ }^{105}$

It was a clever and cunning move by Alauddin. Ironically, Caen's request for a lodge after the formal ending of the meeting June 24 was met by a symmetrical breach of protocol by Alauddin, because he demanded new revisions after the negotiations were supposed to have been concluded. Alauddin's wish to amend and revise put the Dutch in a dilemma. Given his intentions of making the treaty more solid and binding, the Dutch could hardly object without a loss of face. Alauddin's amendment raised the question of jurisdiction in criminal cases in Makassar when Company servants were accused of crimes. Here the sultan demanded that he should hold supreme and sole authority. ${ }^{106}$ Undoubtedly the sultan's amendment was directly connected with the Dutch request for a permanent lodge.

\footnotetext{
102 "omme te dienen tot bondiger onderhoudinghe ende meerder verseeckeringe van't gecontracteerde aen weder sijde." Van Diemen's Report, DRB June 24, 1637, 286.

103 "den vreede recht meenende, ende niet anders socht dan die lang te continueeren." Van Diemen's Report, DRB June 24, 1637, 286.

104 "punctuelick conform de meeninge in’t bijwesen des Coninckx getransalateert ende in Nederlandts overgenomen hadde." Van Diemen's Report, DRB June 24, 1637, 286.

105 Van Diemen's Report, DRB June 24, 1637, 286.

106 "d'onse wanner in sijn land coomen te vergrijpen. Off ijmant te beschadigen straffen sall." Van Diemen's Report, DRB June 26, 1637, 286.
} 


\section{Deliberations and decisions on Alauddin's amendments on board, June 25}

On board the ship, all Alauddin's amendments were found acceptable, except for the one concerning jurisdiction over the Company's subjects when residing in Makassar. Although he euphemistically said that it must be "slightly revised," ${ }^{107}$ Van Diemen's position was that Alauddin's proposal was unacceptable. His counterproposal - that the Company itself should correct its own personnel-represented a radical break with the sultan's claim of full sovereignty. ${ }^{108}$ The Dutch counterproposal thus not only represented more than a "slight revision," it implied an infringement on the sultan's judicial autonomy, or sovereignty. As we have seen Andaya states that this was a point that any South Sulawesi ruler would never compromise on, as it concerned his and his lineage's pride and honour, ${ }^{109}$ but as it was, Alauddin did bargain when the matter became an issue during the further negotiations, and the final solution in the treaty was a compromise between Alauddin's proposition and Van Diemen's counterproposition. The supreme sovereignty of the sultan in cases involving the Company and other European nationals residing in Makassar as well as between the Company and Makassarese subjects and others residing in Makassar was recognised. On the other side, the Company's chief resident had the right to sit in and be heard in such cases. ${ }^{10}$

\section{The June 26 negotiations}

On Friday, June 26, Caen went ashore with an "impressive following" 11 for the final negotiations, bringing with him two documents: the Dutch response to Alauddin's revisions and amplifications from the day before, and the original treaty text of June $24 \cdot{ }^{12}$ In the following exchange with the sultan, Caen first declared that the Company agreed to all of the sultan's minor amendments,

\footnotetext{
107 “Een wenig veranderen.” Van Diemen's Report, DRB June 26, 1637, 286.

108 “dat van ons eigen volck souden blijven corrigeeren." Van Diemen's Report, DRB June 26, 1637, 286.

109 See my treatment of Andaya's positions above.

1101637 treaty, unnumbered art. 5, in which the Sultan's supreme authority was recognised: "alle voorvallende questien tusschen de Nederlandsche ende d'Engelschen, Deenen, Portuguesen, Makassaren etc. bij de Maijesteit affegedaen sall worden ... mits dat het presente Nederlandts oppe hooffd mede in sijn raedt sall compareren." Corpus Diplomaticum, 1.304.

111 “aensienkijcke suijte." Van Diemen's Report, DRB June 26, 1637, 286.

112 Van Diemen's Report, DRB June 26, 1637, 286.
} 
and that these could well be included in the treaty. ${ }^{113}$ He then turned to the controversial issue of jurisdiction over Company servants. Having put forward the Dutch counter-proposition of a "joint" sitting and hearing in such cases, Caen went on to give the Dutch rationale, which tellingly did not represent an example of principal legal thinking "à la Europe." Caen's argument was that the Company's autonomy in jurisdiction over its own personnel was the "standard practice" elsewhere in the Company's area of operation in Asia. ${ }^{114}$

It should be noticed that Caen's argument here is not built upon general principles of law, but on precedents and actual practice. If the argument here is used tactically to acquire rights on par with those of other nations and peoples, it still aligns more with the Directors' recommendations of pragmatism than an appeal to European legal formulas.

In his response, Alauddin stuck to his original position of maintaining sole and unabridged jurisdiction. Any outsider, be they English, Danish or Portuguese, or any other outside people who came to trade, were under the sultan's jurisdiction. ${ }^{115}$ His position on the one hand is thus in keeping with Andaya's proposition about the sacrosanct status of sovereignty in the South Sulawesi states-system. But, on the other hand, it is noteworthy that Alauddin's legitimation of his stand does not refer to idioms of or arguments from this tradition. In fact, he justifies it in the same fashion as Caen, by pointing to already established practice. The sultan's unabridged authority was "the rule and practice that was being followed regarding the handling of justice regarding the English, Danish and Portuguese and all other foreigners that had come to trade in his land." ${ }^{116}$ So, if there were antagonistic positions, the arguments for them followed similar lines: custom and practice was the shared point of reference. A proposition about conflicts of interest within a shared field of competition is then just as plausible a frame of interpretation as one of "conflicting treaty conceptions."

After hearing Alauddin's position and his argument for it, Caen concluded that they would "come no further on this point." ${ }^{117} \mathrm{He}$ would have to confer with Van

\footnotetext{
113 Van Diemen's Report, DRB June 26, 1637, 286.

114 "hoe wij in meest alle quartieren van Indien daer negotieeren meesters over ons volck waerren." Van Diemen's Report, DRB June 26, 1637, 287.

115 Van Diemen's Report, DRB June 26, 1637, 287.

116 (Alauddin) "bleef parsisteerren ende vaststaen also seijde ... d'Engelsen, Portugeesen ende alle andere vremdelingen die in sijn land resideerren off coomen handellen sulcx subject sijn." Van Diemen's Report, $D R B$ June 26, 1637, 287.

117 Van Diemen's Report, $D R B$ June 26, 1637, 287.
} 
Diemen before agreeing, and consequently Caen asked permission to return to the ship to do so. ${ }^{118}$ Back on the ship Van Diemen and Caen came up with a compromise position involving a "slight change" of the text "according to the king's wishes [and] which would be favourable to both sides." ${ }^{119}$ The revision gave the Company's resident the right to appear in the king's council and have a voice in the final decision. ${ }^{120}$ If the Dutch were accorded a place in judicial matters concerning their own personnel, the revised proposition was better for Alauddin than the original one, because the Company was allowed no jurisdictional autonomy, and the sultan's supreme position in judicial affairs was recognised.

The revised proposal was then included in the (new) draft treaty, which was signed and sealed anew by Van Diemen. What was left then should be for Alauddin to accept and sign. Around noon then, and for the second time Caen went ashore, and we must assume in the hope that the treaty would now finally be signed.

\section{The second negotiations, June 26}

Meeting with the sultan for the second time on June 26, Caen offered the revised treaty text to Alauddin for his signature, with the appropriate deference, ${ }^{121}$ upon which the sultan reportedly "showed every sign of satisfaction." ${ }^{122}$ That should have been it-mission accomplished. But there was still another hurdle to jump, and it was Alauddin who set it up. He requested the addition of a clause stating that the treaty would be binding not only for the present governor-general, that is Van Diemen, but for future governors-general as well. ${ }^{223}$ Caen had no objections to this point, and so it was agreed. ${ }^{124}$

\footnotetext{
118 Van Diemen's Report, DRB June 26, 1637, 287.

119 "goetgevonden ... tselve point een weijnich tot des koninckx begeeren tusschen beide te veranderen." Van Diemen's Report, DRB June 26, 1637, 287.

120 "hij [the sultan] over d'onse wanner in hun in sijn landt comen te verlopen of te vergrijppen recht ende justitie recht ende justitie sall mogen administreeren mits dat her presente Nederlants opperhoofd in sijnnen raet compareren ende stemme hebben sall." Van Diemen's Report, DRB June 26, 1637, 287.

121 "met de vereijste eerbiedicheijt." Van Diemen's Report, DRB June 26, 1637, 287.

122 “darinne seer goet contentement nam.” Van Diemen's Report, DRB June 26, 1637, 287.

123 "Doch alsoo considereerden dat de Generaells oordonnararij naer drie jaerren verandert werden... datt dese contractie soo wel bij de naercomelingen als de presente generaell soude van weerden gekent ende achervolgcht warden." Van Diemen's Report, DRB June 26, 1637, 287.

124 Van Diemen's Report, DRB June 26, 1637, 287.
} 


\section{Conclusion, Section 3}

The issue of the treaty's duration illustrates problems in Andaya's approach on a number of issues. It is difficult to see what precisely Andaya would have us believe is the cultural specificity of Alauddin's claim. ${ }^{125}$ The insistence on durability might as likely come from contextual considerations as from spiritual notions of "treaty." In other words, Alauddin may simply have thought that he had gotten the best terms he could under the circumstances.

Even if Andaya's view of the sacred nature of South Sulawesi contract logic is accepted, the question remains: Was it this perception that "directed" Alauddin's expectations and performance during the June 1637 negotiations? Some facts contradict such an assumption. Alauddin was not dealing with another Makassarese power. He was dealing with a European outsider. Second, the issues involved concerned practicalities in formalising a relation with this outside power, not issues of relative hierarchical rank. The context implies that the concerns and conceptions in the South Sulawesian model of diplomacy were irrelevant in the negotiations with the Company from the start.

Third, Alauddin's performance during the negotiations shows that his preoccupation lay with obtaining the optimal results on the practical issues raised by the Dutch. Concerns of prestige and hierarchy were only indirectly involved. Suppose, then, that from Alauddin's point of view, the terms he got at the end of the June 26 session were the best he could get, considering the balance of strength between himself and the Company. Alauddin's insistence on the permanence of the treaty may too just as well be explained by contextual as by structural reasons. The former explanation is actually supported by Alauddin's remark in the treaty text itself, where he says that he would have wished it otherwise, but in view of the Dutch naval military strength he saw no other option but to accept. ${ }^{126}$ Taking such contextual considerations into account, Alauddin had immediate reasons for insisting on the perpetuation of the treaty. The claim may thus not have stemmed from particular South Sulawesian sacred conceptions of treaty, but more likely from contextual concerns over secular power politics. This proposition has more general methodological

\footnotetext{
125 See section 1 , above.

126 "Dat hem in zijn rijck geensints sullen sullen mogen beschadigen, allsoo tegen de Nederlanders geringh van maght zegt te wesen." 1637 treaty, unnumbered art. 2 (see also unnumbered art. 7), Corpus Diplomaticum, 1.304. See analysis of treaty text, below.
} 
issues. For in Andaya's explanation, we are invited to explain Alauddin's actions as reflexes where "tradition is speaking through him." But the evidence of the negotiations suggests otherwise, namely that Alauddin was consciously acting out of secular reflections on the situation and context he was in.

Finally, Alauddin was acting in a mode that was understood by the Dutch. As for miscommunications, insistence that the treaty was binding "forever" was not a foreign idea never formulated in the VOC contracts ${ }^{127}$. But in all fairness, it must be taken into account that Andaya's argument for misconception is that "forever" meant something different in the South Sulawesi context than in the Dutch, given the sacred or metaphysical logic in which it was conceived. But that counterargument rests on the assumption that Alauddin was bringing his local conception of treaty to the negotiations with the outsider Dutch, that is, that he was disregarding the fact that he was dealing with "outsiders." But, if we follow Resink, the Makassarese had their own separate institutions reserved for dealing with outsiders. The proposition is also weakened by Alauddin's performance during the negotiations, which reveals a preoccupation with specific regulations.

There is hardly any correspondence between Alauddin's actions during the June negotiations 1637 and what one might expect from Andaya's conception of the typical South Sulawesi treaty. Contrary to Andaya's propositions about the relatively peripheral position of specific regulations in the treaty, and compared to the primary focus on the treaty as a "mythical" regulation of relative status positions of treaty, Alauddin's preoccupation in his dealings with the Dutch lay in the substance of specific treaty regulations. The back and forth and the final agreement over the issue of jurisdiction over Company servants in Makassar illustrates this well. Nor does the Dutch performance fit with assumptions about being "hung up" by a master manual of "international law." The 1637 treaty was a negotiated one, with give and take on both sides. Judging from their respective performances, both Van Diemen (and Caen) and Alauddin acted pragmatically during these negotiations, trying to get their best in the circumstances they were in. "Their best" meaning the best practical solutions to actual problems, neither conceived nor articulated in terms of local tradition or in terms of international law.

That Alauddin's insistence on permanence was accepted on the spot corroborates the proposition that the Dutch also felt that they had obtained

127 chapters 7 and 8 below. 
the optimum result. In fact, for all the initial misunderstandings leading up to the negotiations per se, and for all the hurdles during the negotiations, the two parties understood each other well enough to conclude a treaty that was characterised by compromises.

\section{Section 4: Text, meaning, and nature of the June 26 treaty}

\section{Section introduction}

For Andaya, what caused the clash in making the Company-Makassar treaty was that the former stuck to European standards and methods that were incompatible with the South Sulawesian tradition. In the section on the negotiations for the 1637 treaty, I have argued that this seems a dubious proposition. What I shall do in this section is to demonstrate that neither Andaya's proposition about the typical European reference to international law, nor his assumption of miscommunication due to conflicting and incompatible frames of cultural references are convincing when we consider the text of the final treaty.

\section{The typical Company treaty as opposed to the South Sulawesian tradition, according to Andaya}

The expectation in the South Sulawesi function and meaning of "treaty" was that it served to reflect shifts in power relations and alliances. It was dynamic and flexible: the constant alignment and realignment of vassal states from one overlord to another was an expected phenomenon that resulted from an on-going process by which each state sought its proper level within the interstate hierarchy. Shifts in alliances that resulted from new agreements were not seen as breaches of contract in South Sulawesian logic, but as a reflection of the South Sulawesian leaders' subtle understanding of the function of both while assuring the political as well as the spiritual welfare of their states. ${ }^{128}$

128 Andaya, “Treaty Conceptions and Misconceptions," 285-86. 
Leaving aside the unlikely implicit proposition that South Sulawesians assumed that by concluding a treaty with an outsider party like the Company the latter was automatically included in the local hierarchy of power, Andaya's point is that European standards and the Company's practice were built on a totally different platform. In Andaya's words, the Company "introduced a new concept of treaties and treaty-making in South Sulawesi." "129

What was then so "new" and "different" about it? The emphasis in the European contracts lay on specified and detailed regulations with the expectation that these be honoured as to their precise and specific wording: According to Western European treaty practices at the time, once a treaty text had been formulated, "the provisions therein were considered to be binding to all signatories." ${ }^{130}$ The dynamism and flexibility that lay in the South Sulawesian conceptualisation of "treaty" were then consistently interpreted as lack of trustworthiness and breaches of contract. Whereas local South Sulawesi treaties in essence represented a mechanism for the distribution of political and spiritual "capital," to the Company they represented a means for acquiring profit: "The treaties between the Company and the native states were ... always basically commercial with the foremost aim being the acquisition of trading advantages for the Company. But such treaties were totally alien to the concept of treaties in South Sulawesi." ${ }^{131}$

So, both in meaning and intent, the treaty making between the Company and Makassar represented a clash between two conceptual worlds. That applied to the respective forms of the treaties, as well; i.e. between the South Sulawesian treaty whose general function lay in preserving "harmony in society", ${ }^{132}$ and the typical Western treaty with "its carefully worded articles." ${ }^{133}$

\section{Accommodation as the exception to the rule}

Andaya notes that elements from the South Sulawesian tradition could be incorporated into the treaty text. He also mentions that at times, the Company incorporated elements of the local treaty mode and form; but this was the

\footnotetext{
129 Ibid. 286.

130 Ibid. 286.

131 Ibid. 288.

132 Ibid. 284.

133 Ibid. 286.
} 
exception, and limited to cases where the Company was in a weak negotiating position or in dealings with insignificant native states. ${ }^{134}$ Thus, Andaya's argument for explaining the exception to the rule is that the Company would depart from its preferred mode of imposing its own treaty tradition either when it felt itself bargaining from a weak position, or from a position where it felt no threat at all.

\section{Andaya on antagonistic interpretative frameworks as the rule}

One should note that although Andaya seemingly allows for the possibility of compromise, the idea of compatibility is still rejected. If there is compromise, it is really the conjoining of separate forms. Andaya's perspective does not allow for compromise as mixing and blending on the same and individual point, because real communication is ruled out by the assumption of antagonistic interpretative frameworks. But, as I have tried to demonstrate in my discussion on the negotiations, the making of the 1637 treaty was a process between actors who did communicate with each other in meaningful ways. That is reflected in the text of the treaty, which precisely puts down the mix of concessions and gains on both sides arrived at during the negotiations. To demonstrate my point that the treaty was a result of give and take, I shall give a brief overview of the contents of the respective clauses, before analysing in more detail how the issue of sovereignty is handled.

\section{The specific regulations of the treaty}

The specific regulations in the 1637 treaty are not numbered. ${ }^{135}$ Simple reckoning by paragraphs starting with "that," and splitting one of these into two, yields twelve specific regulations in all. I shall briefly summarise the contents of each separate "article," and indicate the connection between the final regulations and the negotiations that led up to them. For the sake of clarity, I will use my own numbering of the clauses. All references are to Heeres' Compilation.

\footnotetext{
134 Ibid. 287.

135 See section 1 , above.
} 
The first clause states that the Company's right to establish a lodge remained restricted to the periods when its ships were in the roadstead of Makassar. ${ }^{136}$ The final regulation on the issue of the Company's request for a lodge thus reflects a compromise between Caen's request and Alauddin's response on the first day of real negotiations, when Alauddin rather coldly had retorted to the Company's request that "first they had to come to trade."137

In the second clause, the Company's obliges itself to guarantee the sultan's sovereignty and safety, ${ }^{138}$ and in the third clause this obligation is elaborated to apply to all foreigners residing in Makassar. ${ }^{139}$ Not stated, but implicitly clear enough, the Dutch were not to start any hostilities towards other European nations while in the sultan's domain.

Not introduced by a "that," but still an issue by its own right, the ban on Makassarese sailing to Malacca and the coast of Ceram is included in the third clause. ${ }^{140}$ The reason why it is included in the paragraph banning Company violence in the sultan's domains is easy to understand. It states an exception to the ruling of nonviolence by the Company because it allowed sanctions against sailings in the "unfree areas." As had been agreed during the negotiations, then, the responsibility of enforcement lay explicitly in the hands of the Company.

The fourth item concerns the mode of action in case of conflict between the Company and the sultan's subjects. Such conflicts should not be regarded as breaches of the peace between the Dutch and Makassarese people, but be handled in "the most delicate manner." ${ }^{141}$ The regulation thus represents the final agreement on the back and forth haggling on the issue during the negotiations.

136 "dat zoo lang hier een off meer schepen ter rheede hebbende." 1637 treaty, unnumbered art. 1, Corpus Diplomaticum, 1.303 .

137 See section 2, above.

138 "Hem in zijn rijck geensints sullen mogen beschadigen." 1637 treaty, unnumbered art. 2, Corpus Diplomaticum, 1.304 .

139 "De Nederlanders ook gedurende desen vreede niet vermogen zullen, tegen Zijne Maijt nogh niemandt onder desselfs gebiet sorterende vijandtlijckheidt te betoonen." 1637 treaty, unnumbered art. 3, Corpus Diplomaticum, 1.304.

140 "Behoudens dat desselffs subjecten in onvrij vaarwaters, te weten omtrent Malaca, op de cust van Ceram etc. sullen vermogen als vianden aen te tasten ende te nemen, ' $t$ welck aen dit tractat geen infractie zall veroorzaeken." 1637 treaty, unnumbered art. 3, Corpus Diplomaticum, 1.304

141 "Dat om particuliere questie met ijmandt van de zijne geen verbrekingh van vrede comen, maer op het gevoeghelikste gemodereerdt werden zal." 1637 treaty, unnumbered art. 4, Corpus Diplomaticum, 1.304 . 
The fifth ruling concerns how to handle eventual conflicts between the Company and the other European nations residing in Makassar. The procedure agreed upon is that the sultan should have "the final say." 142 The Company's senior merchant (opperhoofd) was, however, accorded the right to sit in and be heard at the proceedings. ${ }^{143}$ The final wording on the issue then reflected the last Dutch compromise proposal by the Dutch to Alauddin's rejection of their original proposal during the negotiations.

The sixth ruling is partly in favour of Alauddin's interests as it expressly forbid violent actions by the Company against its European enemies in Makassar's roadstead. ${ }^{144}$ At the same time, the Dutch were to enjoy the same freedoms as the other European nations ${ }^{145}$ - another negotiated compromise inscribed in the treaty.

The issue of intra-European fighting in the harbour at Makassar is further elaborated on in the following paragraph, which simply states that the sultan neither could nor would be held responsible for such belligerent actions. ${ }^{146}$ An explicit explanation is given whereby the sultan points to his impotence regarding naval military strength. ${ }^{147}$ Still the Company was declared free to chase and fight their enemies outside the roadstead. ${ }^{148}$

The eighth unnumbered clause treats the political relations between the Company and Makassar more generally, defining their rights of autonomy in foreign policy and defining limits to their mutual commitments. Each party was free to attack its own enemies, but neither was obliged to assist the other in case of an attack by a third party. ${ }^{149}$ In short, the Company and Makassar were not allies.

\footnotetext{
142 “Bij de Maijt. affgedaen zall worden." 1637 treaty, unnumbered art. 5, Corpus Diplomaticum, 1.304.

143 "Mits dat het presente Nederlandts opperhoofd mede in zijn raedt sall compareren." 1637 treaty, unnumbered art. 5, Corpus Diplomaticum, 1.304.

144 “zijn rheede ongevioleerdt zullen laten." 1637 treaty, unnumbered art. 6, Corpus Diplomaticum, 1.304.

145 "De Nederlanders ende ook gelijcke vrijheidt (as the other Europeans in Makassar) genieten." 1637 treaty, unnumbered art. 6, Corpus Diplomaticum, 1.304.

146 "hem (the Sultan) allsdan de schullt niet sullen geven." 1637 treaty, unnumbered art. 6, Corpus Diplomaticum, 1.304 .

147 "allsoo sulx ter zee niet beletten kan." 1637 treaty, unnumbered art. 6, Corpus Diplomaticum, 1.304.

148 "Mits dat de Nederlanders op gelijcke maniere bij gelegenheidt hare revenge sullen mogen nemen." 1637 treaty, unnumbered art. 7, Corpus Diplomaticum, 1.304.

149 "Dat ijder met zijn vijanden zal aenspringen, sonder gehouden te wesen den andren te adsisteeren." 1637 treaty, unnumbered art. 8, Corpus Diplomaticum, 1.304.
} 
The ninth article represents a qualification of the preceding one. The nonalliance status was modified by a reciprocal vow not to enter secret negotiations with third parties, which might jeopardise the peace. ${ }^{150}$ So, there were some restrictions on autonomy after all.

The tenth unnumbered article is the only one concerning trade directly, specifying export tolls, ${ }^{151}$ whereas the final two clauses concerned actions to be taken in cases of runaways and converts. They included the reciprocal obligation of returning runaways ${ }^{152}$ and a reciprocal abstention from acts of conversion. ${ }^{153}$ The treaty concludes with the amendment, presented by Alauddin on the final day of negotiations that the treaty should be binding on future governors- general.

\section{Comments: The nature and form of the treaty}

The 1637 treaty presents regulations for practical issues concerning political relations between Makassar and the Company. Of the twelve clauses, only one concerned regulations on commercial interactions. The regulations for political interaction, regarding both relations with third parties and bilateral relations between Makassar and the Company, predominantly represented issues that had been brought up during the negotiations, or were derived from them. None of them were formulated in European legal terms, nor made with reference to international law. All of them were casuistic, and formulated with due regards to specifics. As such, none left much room or need for "cultural interpretation."

Had Alauddin applied a local South Sulawesi treaty conception along the lines of Andaya's model, he would have been blinkered. But his performance during the negotiations proves that he was not. The imprint of the negotiated compromises in the final treaty gives the same impression. I shall elaborate the proposition of Alauddin's accommodated" concept of "sovereignty" in further detail.

\footnotetext{
150 "Dat van beijde zijde geen vreemde praetjens ofte uijtstroijselen die den gamaeckt vreede eenighsints hinderlijck moghten wesen, lightelijck sullen aennemen." 1637 treaty, unnumbered art. 9, Corpus Diplomaticum, 1.304 .

1511637 treaty, unnumbered art. 10, Corpus Diplomaticum, 1.304.

1521637 treaty, unnumbered art. 11, Corpus Diplomaticum, 1.305.

1531637 treaty, unnumbered art. 11, Corpus Diplomaticum, 1.305.
} 


\section{The issue of "sovereignty"}

Andaya's proposition is that "sovereignty" in the South Sulawesian sense was a sacred concept infused with emotions of pride and prestige, ${ }^{154}$ and thus constituted the core of South Sulawesian thinking on self-esteem and rank. ${ }^{155}$ It was an issue for which any South Sulawesian ruler would sooner give his life than compromise on. ${ }^{156}$ But, Alauddin all the same did compromise with the Company in 1637 , and consciously so, most likely to protect his realm.

In the preamble of the Contact between Makassar and the Company of June 26,1637 , the type of treaty is given as "agreed conditions for peace." 157 Alauddin's status as contractor was given as "king of Makassar" and he was titled "His Majesty." Van Diemen acted as contractor on behalf of the Company in the position as governor- general of "The Dutch state in Asia." ${ }^{158}$ The preamble then clearly deviates from the typical South Sulawesi diplomatic idiom, as no specific type of relationship or implicit distribution of reciprocal rights between the contractors was included. Still, rather than looking at this as an intrusion of Company standards, this might be explained by the fact that neither party saw the inclusion of the Company into the local South Sulawesi states system as relevant. After all, Alauddin did not even accept a permanent Company lodge in Makassar. The South Sulawesian model of preamble might simply have been regarded as both irrelevant and undesirable to him.

The same goes for labelling the agreement as a treaty of peace rather than as an alliance. Van Diemen probably hoped for the latter, but the request was quickly put aside. Alauddin, on his side, must have preferred a treaty of peace and peace only rather than an alliance, as his performance during the negotiations indicates that he was trying to avoid any tighter bonds than the ones he could not refuse without risking war with the Company.

The preamble is furthermore clearly "European" in the sense that it is presented as a symmetrical state-to-state treaty. Such symmetry does admittedly mark a break with the South Sulawesi traditional preoccupation with

\footnotetext{
154 Andaya, “Treaty Conceptions and Misconceptions," 284.

155 Ibid. 285 .

156 Ibid. 284.

157 "Conditien ... op het treffen van de vrede." 1637 treaty, Corpus Diplomaticum, 1.303.

158 "den Nederlandtschen stant in Orienten." 1637 treaty, Corpus Diplomaticum, 1.303
} 
hierarchy. ${ }^{159}$ But did that mean it was incomprehensible to Alauddin and that consequently he could not act rationally within such a framework? The counter-propositions and amendments that Alauddin came up with during the negotiations and the compromises laid down in final text give little merit to such a proposition. Both point more in the direction of a ruler trying to preserve his symmetrical position in relation to the Company while keeping the Dutch at arm's length. In other words, the South Sulawesian thinking about hierarchical systems did not apply in Alauddin's strategy towards the Company. The issue was "sovereignty" and autonomy, but these concepts may not have been conceived in the South Sulawesian framework in dealings with the Company. More likely, they functioned as defensive tools for holding a threatening outsider at bay.

\section{Explications and implications of secular, defensive "sovereignty"}

Eight of the articles in the 1637 treaty concern the demarcation between the Company's rights and the sultan's sovereignty, either in his domestic realm or his and the Company's relations with third parties. Not discounting that prestige and pride were parts of Alauddin's package of concerns, and for the sake of argument, even accepting that metaphysical concerns held priority on the local scene, a concern for secular power compatible with the Dutch conception underlay the compromises reached during the negotiations and was inscribed in the final treaty.

Consider, for instance, the second clause concerning the keeping of peaceful relations. Alauddin demands a binding oath regarding the Company's peaceful intentions "that [the Company] should never do him any harm." ${ }^{160}$ Alauddin himself gives a secular reason for the compromise on his authority on this issue, namely his underdog position compared to the Company as far as military power was concerned. ${ }^{161}$ Concerns about secular power seem more likely as a motive than prestige and pride in the spiritual sense here.

\footnotetext{
159 Andaya, "Treaty Conceptions and Misconceptions," 285.

160 "dat hem in zijn rijck geensints sullen mogen beschadigen." Corpus Diplomaticum, 1.304.

161 "also tegen de Nederlanders Gering van maght zeght te wesen." Corpus Diplomaticum, 1. 304, also quoted above.
} 
The fourth ruling, which stated that conflicts between Company servants and the sultan's subjects should not be regarded as a breach of the peace and that such problems should be solved by delicate mediation, represented another negotiated compromise. But, if Alauddin ultimately felt that the final ruling meant an undermining of his sovereignty, the negotiated solution was still better than the initial Company proposition. Considering that a uncompromising stand on the issue might well have led to open war, which is the implication of Alauddin's lament about his relative inferiority in strength, the final compromise on the issue of jurisdiction might well have represented considerations of a secular and contextual nature. The point is that primary concerns of prestige and pride and metaphysical considerations do not invite compromise to the same degree. The same goes for all the compromises in the treaty: in the procedure for handling conflicts between the Dutch and other Europeans in Makassar, as well as between the Dutch and the sultan's subjects, treated in the fifth clause, and the threat to his sovereignty by the imminent danger of the Company bringing its wars with European rivals to Makassarese waters, the topic of the sixth and seventh articles. One can almost hear a sigh of resignation in Alauddin's recognition of the Company's right to pursue its enemies. It is followed up by Alauddin's admission of his own impotence as far as naval warfare was concerned: "At sea, there was nothing he could do about it." ${ }^{162}$

In Alauddin's admission above, we are confronted with a kind of conceptualisation of sovereignty and power that is neither abstract nor "mystic" but secular and contextual. The same goes for the regulations on prohibited and permissible alliances in the two succeeding articles, which obviously represented an infringement on Alauddin's autonomy. But what Alauddin achieved was better than an enforced alliance. And it is clear that what the Dutch obtained was less than what they wanted, too, namely a treaty of "peace and friendship. ${ }^{163}$ The final treaty specifies terms for a bilateral peace, but with no strings from a bilateral alliance attached. Somewhere along the line, Van Diemen and Caen must have opted merely for "peace," considering it to be the best they could get, and the peace they got was the maximum Alauddin was willing to offer.

\footnotetext{
162 "hem (the Sultan), also sulx ter zee niet beletten en kan," unnumbered art. 7, Corpus Diplomaticum, 1.304 .

163 See below, and: "section 1."
} 
That the Company-Makassar relationship was an evolving one, and thus both fragile and fluid, can also be seen in the curious ending of the eighth clause. Having stated beyond any reasonable doubt that the Company and Makassar were not allies, there comes a passage that presents a lamentation on the absence of positive obligations to assist each other: "even if inclined to do so," ${ }^{164}$ which suggests that the Company intended to secure a positive alliance from the outset. The Dutch "sigh" was probably what was left of Van Diemen's initial hope for a treaty of alliance.

The hoped-for positive alliance becomes clear from the following paragraph, which is formulated like an advertisement for an alliance partnership with the Company. Compassion and loyalty were the typical traits of the Company's treatment of its alliance partners: "The Dutch always felt an obligation to protect their allies against unreasonable harassment." 165

The meaning of these formulations, which by the way clearly must be ascribed to the Dutch, can be interpreted in a different way, however. In addition to being seen as an implicit invitation for Alauddin to enter into an alliance with the Company, it could also be read as an implicit warning about the Company's intention to interfere on behalf of its allies in Makassarese waters, if Makassar decided to go against them. Maybe for that reason it was a "protection" that Alauddin never asked for.

As for implicit subtleties, the above example is as close as we get in the treaty text. Furthermore, none of the articles are formulated with reference to or in terms of international law. The general characteristic of the treaty is that the regulations represented concise formulations on the compromises that had been reached during the negotiations. What we see in the final treaty is not at all the product of "cultural collision." Neither is it a dual product with disconnected components of the South Sulawesian and Western treaty traditions. It represents the endresult of the give and take process that started with the negotiations of June 24-26.

\footnotetext{
164 “off te ware sulx uijt lieffde deden," unnumbered art. 8, Corpus Diplomaticum, 1.304.

165 "behoudens dat de Nederlanders t'allen tijde haere gealieerde tegens onbehoorlijcke overlast moeten protegeren," unnumbered art. 8., Corpus Diplomaticum, 1.304.
} 


\section{Chapter conclusion: Treaty compromise by context and meaningful communication, not cultural collision and miscommunication}

Rumours about Van Diemen's mercilessness in defending the Company's monopoly in the Moluccas ${ }^{166}$ must have reached and made an impact on Alauddin before the 1637 negotiations. It is reasonable to see his recurrent lamenting about his relatively weak naval strength in the light of his fears of Company war actions. Alauddin's handling of the Company's claim to the right to pursue their Spanish and Portuguese enemies in Makassarese waters points in the same direction. The final agreement thus represented a pragmatic solution reached by rational calculation, in which Alauddin's considerations on asymmetrical capacity for maritime warfare must have played a role. Similarly, his decision to allow the Company to sit in on the cases involving Company personnel represented a pragmatic solution. Although both these issues had clear implications regarding sovereignty, they were treated as practical problems, and solved pragmatically. No principles of international law, no references to South Sulawesian concepts of "sovereignty" were involved, either during the negotiations or in final treaty.

The 1637 treaty was not the outcome of representatives of two parties speaking mutually unintelligible languages. It came about as a result of mutual negotiations over secular interests in a context in which both parties considered reaching a negotiated solution better than the alternative. The two parties understood each other well enough to make meaningful communication possible. Their initial modes or models of diplomacy and treaty making may have been different; but they were not so incompatible as to make meaningful communication impossible.

166 Witteveen, Antonie van Diemen, $217 \mathrm{ff}$. Witteveen also underlines that Van Diemen, apart from using his "iron fist," could also use a "velvet glove" (218), as was the case with Makassar in June 1637. 



\section{5}

\section{Policy Discussions and the 1655 Treaty with Makassar-A Matter of Trust and Belief}

\section{Section 1: Chapter introduction}

The topic of this chapter is the deliberations that occurred within the High Government of Batavia concerning Makassar in 1655, and the treaty, which was made on basis of the decisions on policy that were reached. ${ }^{1}$

\section{The 1655 context}

On October 23, 1655, the High Government decided to find out if the Makassarese were inclined towards peace and sent members of the Council of the Indies, the governor of Ambon, Willem van der Beeck, ${ }^{2}$ and the Armenian trader Chodia Soliman to determine if this was the case. ${ }^{3}$

When the High Government took the initiative for peace negotiations in October 1655, it was for several reasons, chief among them the Directors' worries about the high costs of the war and its detrimental effects on trade. ${ }^{4}$ But seen in a broader perspective, and of more relevance in explaining Governor-General Maetsuyker's willingness to accept the treaty terms of the 1655 treaty, is probably the Company's pressed situation at the time.

\footnotetext{
1 For the period from the conclusion of the 1637 Treaty to the outbreak of the war I refer to the chronology of Company-Makassar relations p 10-11. above.

2 Van der Beeck was until 1654 Governor of Ambon, Stapel, Het Bongaais Verdrag, 53, n. 4.

3 Ibid. 53.

4 Ibid. 53 .
} 
After the end of the truce with the Portuguese in 1651, the High Government received orders from the Directors to continue the struggle against the Portuguese east of the Cape. ${ }^{5}$ The Company was thus engaged in war with the Portuguese in Ceylon until 1656. ${ }^{6}$ Relations with Banten also caused concern, particularly following the installation of Ageng as sultan in 1651.7 Added to this, the relations with Palembang and Aceh were troubled. ${ }^{8}$ Finally, the Company's position in Taiwan was worrisome, affected as it was by the chaos resulting from the civil war between the Manchus and Ming loyalists in the south, among them Coxinga, who was no friend of the Company. ${ }^{9}$ Given these concerns, and with troops tied up in the Moluccas and Ceylon, ${ }^{10}$ one must conclude that there were also external pressures for making Maetsuyker accept the terms of the treaty of December 28, 1655. As for the reasons for declaring war in the first place, the conflict over destitution claims regarding the São João Baptista and Nazareé ships, which involved both Francisco Vieira de Figueiredo and the Sultan, must be added. ${ }^{11}$

\section{Chapter sections and propositions}

I shall begin by giving a brief chronology of the diplomatic interaction between 1650 and 1655 to clarify my subject and my propositions. The analysis proper consists of three sections. The first concerns the Directors' advice on Makassar in the 1650 General Instructions; I intend to identify the general scope of manoeuvre and approach that the Directors' gave the High Government. I propose that the tenor of the advice on Makassar conforms with the generally pragmatic approach to overseas diplomacy in the 1650 Instructions. In the following section, I undertake a textual analysis of the conflicting views over policy between Governor-General Maetsuyker and the Governor of Ambon, De Vlaming van Oudshoorn, at the close of hostilities in 1655. The latter saw total victory over Makassar as a necessary precondition

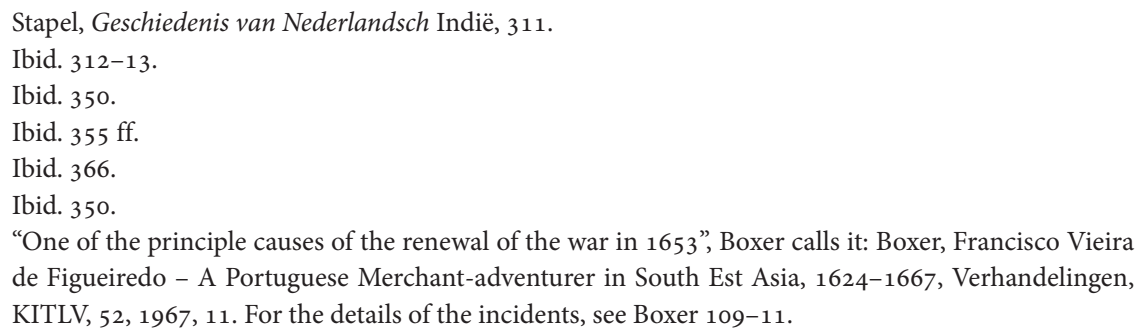


for the establishment of a lasting peace and the protection of the Company's interests in the Spice Islands, whereas the former argued that the conclusion of a satisfactory treaty by fall 1655 was not dependent on a total military victory.

I propose that although the two parties held contrary views, their respective arguments sprang from the same raisons détat. The difference between the two lay in their perceptions of Makassarese intentions: Maetsuyker's arguments were built on trust in the Makassarese, De Vlaming's on distrust.

When Maetsuyker won the day, the form of the proposed peace treaty of 1655 was based on the assumptions that the Makassarese were sincere in their wish for peace and their vow not to interfere with the Company's trade monopoly in the Spice Islands. In the third section, I analyse the regulations and formulations in the 1655 treaty from this perspective.

In summary, my aim is to demonstrate that the advice of the Heeren XVII on Makassar, the discussions between De Vlaming and Maetsuyker, and the regulations and formulations in the December 28 treaty all sprang from considerations of local context. The Company's policy towards Makassar between 1651 and 1655, the 1655 discussions on how to deal with Makassar in the future, and the final arrangements in the 1655 treaty all serve as examples of pragmatic overseas diplomacy.

\section{Sources}

The following chronological overview is mainly based on Stapel's Het Bongaais Verdrag, ${ }^{12}$ which in its turn to a large extent is built on Valentijn. ${ }^{13}$ In the first section of textual analysis, I rely mostly on the advice regarding Makassar in the 1650 General Instructions. ${ }^{14}$ The policy advice and instructions in individual letters from the Directors during the main period are not analysed, but only referred to because of their influence on policy decisions in Batavia. The 1650 Instructions offers the framework within which the High Government was supposed to work.

As for the discussion between Maetsuyker and De Vlaming, I rely on Maetsuyker's general letter of December $24,1655,{ }^{15}$ which refers to De Vlaming's

\footnotetext{
12 Stapel, Het Bongaais Verdrag (PhD diss., Leiden University, 1922).

13 François Valentijn, Beschryvinge van Oost Indiën, vol. 1 (Dordrecht: 1724), Molukse Zaaken, 1.286323, and Ambonse Zaaken, 2.166-203.

14 All from Mijer, Verzameling van instructiën.

15 December 24, 1655, GM 3.4-8.
} 
arguments. Maetsuyker's advocacy of the negotiation options to the Directors and his implicit refutation of De Vlaming's plan offer a coherent and consistent deliberation on policy options from which it is possible to reconstruct a "diplomatic worldview." Still, some comment on the use of the Generale Missiven as a source for understanding diplomatic culture and outlook is needed.

\section{A comment on the Generale Missiven as a source for understanding "overseas diplomatic culture"}

The High Government's reports on its dealings with and decisions on policy to the Directors could well be said to represent justifications of how the Company rights and interests had been protected and defended. According to $\mathrm{W}$. $\mathrm{Ph}$. Coolhaas, Maetsuyker particularly underlined this. If the Generale Missiven were aimed at pleasing the Directors, they are all the more relevant as a key to understanding the shared diplomatic culture of the High Government and the Directors at the time. The same goes for De Vlaming's argument for a military solution. The factual contents are not the issue here in either case, but I shall focus on the mode of arguing as indicators of perceptions and attitudes. In this capacity, the discussion over policy towards Makassar in Maetsuyker's general letter and De Vlaming's letter to the Directors show equally well what the two men thought might please and convince the Heeren XVII.

\section{Section 2: Conflicting assumtions of diplomatic performace 1650-1655}

\section{A brief chronology of diplomatic interaction, 1650-55}

The Makassarese stand on allowing permanent residency for the English and Portuguese but not for the Company was a thorn in Batavia's side. ${ }^{16}$ On February 28, 1650, Evert Janssen Buys was sent to Makassar with instructions to enhance the Company's prestige and discredit the Company's European rivals there. ${ }^{17}$ Sultan Maliki Said was given an extract of the 1648 HispanoDutch Treaty of Münster that emphasised the considerable concessions that had been made by the Spanish. ${ }^{18}$ The story of the beheading of Charles I in

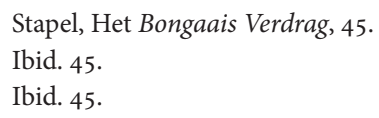


1649 was used to discredit the English. ${ }^{19}$ Although partly a matter of prestige, the wish to establish permanent residence in Makassar had to do with the need to acquire a steady flow of information on what was going on there.

The conflict between the Company and Makassar stemmed from the fact that smuggling from Ambon undermined the Company's monopoly regime in the Moluccas. When rebellion in Ambon broke out again in $1648,{ }^{20}$ the Company suspected and later verified Makassarese support for it. ${ }^{21}$ War with Makassar as a result became the only option. A decision for war was made by the High Government on October 23, 1653, and on November 8, Admiral De Vlaming van Oudshoorn set out as superintendent of the eastern quarters, and commander of the land and seas forces. ${ }^{22}$

It is important to note that the final decision to go to war on Makassar did not come until the fall of 1653 after a series of failed missions to seek a peaceful solution. These negotiations were respectively Jacob Hustard's mission, which left Batavia January $16,{ }^{23}$ and that of Evert Buys, whom De Vlaming sent from Buton on June $18 .{ }^{24}$ De Vlaming took his own initiative for negotiations on September 22 of the same year. ${ }^{25}$ On the news of the Sultan Maliki Said's death and the instalment of his son Hasanuddin as sultan, the decision was taken on December 10 to send Buys to Makassar to see if the mood had changed for the better. ${ }^{26}$ When he confirmed that this was not the case, the war was escalated. The initiatives to see if a negotiated solution could be reached were important in two respects. They underscored the fact that negotiations were the preferred means for solving the conflict with Makassar. The decision to start negotiations again upon the accession of a new sultan, hints that the evaluation of the Makassarese plans and prospects determined the choice between the continuation of war or the start of negotiations for peace. In 1655, the central issue for the High Government became when and how to conclude the war. It was on this issue that De Vlaming and Maetsuyker laid out their differing assumptions about the intentions of the Makassarese.

\footnotetext{
19 Ibid. 45.

20 For the various rebellions in Ambon, see Blussé and de Moor, Nederlanders Overzee, 138-41.

21 Stapel, Het Bongaais Verdrag, 46-47.

22 Ibid. 49.

23 Ibid. 46 .

24 Ibid. 47.

25 Ibid. 49.

26 Ibid. 50.
} 
The decision to seek peace with Makassar by negotiations to be carried out by the Council of the Indies on October $23^{27}$ was partly motivated by pressure from the Directors, who felt that the war was costly in terms of both military expenditures and loss of trade. ${ }^{28}$ As we shall see, Maetsuyker adopted this line of argumentation.

As it was, Van der Beeck and Soliman, arrived in Makassar December 28, and were successful in their dealings. A treaty between Van der Beeck on behalf of the Company, and Sultan Hasanuddin of Makassar was signed December 28 and countersigned in Batavia February 2, 1656.

\section{Makassar as a category 3 territory in the 1650 General Instructions}

At the outset, Makassar belonged to the polities that fell under category 3 of the 1650 tripartite classification. As such it was a place of trade where the Company could neither dictate nor decide the terms of interaction, but should accommodate itself to the local ruler. ${ }^{29}$ As we have seen, the advice on mode of operation in places falling under category 3 was that the Company must trade "without causing any offence to anybody." ${ }^{30}$ The importance of information gathering was also stressed. ${ }^{31}$ Finally, the High Government was instructed to take particular care not to cause conflict with the local princes and rulers of those places $^{32}$ because that would prove "most harmful for the Company's well-being." ${ }^{33}$ This general advice also applied to Makassar.

Yet, Makassar was an extraordinary case. Thanks to its proximity to and entanglement in affairs of the Eastern Archipelago, it was a place of primary importance to the Directors, as its actions had direct implications for the Company's possessions and position in the region.

That Makassar was intrinsically intertwined with the Company's vested interests in the Moluccas modified the recommended restraint and

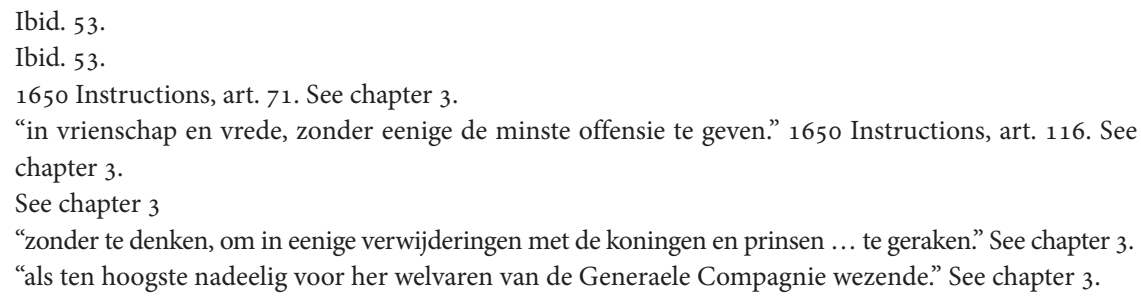


accommodation, and amplified the Company's need to obtain information on Makassarese plans. This was, however, hampered by the absence of a permanent Company residency. In the 1650 Instructions, information gathering was stressed by the Directors as being vital to improving the Company's relative position compared to the English and the Portuguese.

Two articles in the General Instructions of 1650 are devoted to Makassar, namely articles 44 and 45 . In the former it is emphasised that the profits that could accrue from trade on Makassar should not be the High Government's primary concern. Taking the magnitude of trade and therefore also the great numbers of people frequenting Makassar into consideration, the Company should trade there with the aim of obtaining information, particularly on the doings of other European traders." ${ }^{34}$ The Company must further out seek information with a particular eye to whether in due time a situation might arise whereby the Company could get ahead of its European rivals. ${ }^{35}$ In other words, the Directors encouraged information gathering from a political and commercial point of view.

Profit-making motives were however entangled with political ones. The smuggling and trade of cloves from Ambon via Makassar was the subject of the article 45. The cloves brought by Makassarese sailing to Ambon and sold to the English and Portuguese residing there was causing "considerable damage" ${ }^{6}$ to the Company. Although this smuggling seemed to be subsiding, the High Government was reminded that one could never know whether there would be an upsurge in the future. It was therefore "all the more important for the Company's servants to stay in contact with the king and Court of Makassar to keep their ears and eyes open to what was really taking place there, and what might serve the Company." ${ }^{37}$

Article 45 merely repeated the substance of the preceding one. The only difference between the two paragraphs was their perspective. Article 44 concerns

"om nevens de kleine negotie van de Compagnie aldaer te hooren en te zien wat er passeert en zonderling ten regarde van de europeische negotianten." 1650 Instructions, art. 44, Verzameling van instructiën, 81 .

"op welcke action (de europeische negotianten) naauw gelet moet worden, om dezelve in tijd en wijle naar gelegenheid van zaken te mogen preveniëren.” 1650 Instructions, art. 44, Verzameling van instructiën, 82

37 "de presentie van de ministers van de Compagnie omtrent het hof en den koning van Makassar te meer nodig is, om te hooren en te zien, wat aldaar passeert, en de Compagnie te mogen dienen." 1650 Instructions, art. 45, Verzameling van instructiën, 82. 
the relative standing of the Company as compared to its European rivals in Makassar, while the second deals with the issue of smuggling directly. The shared message was that the High Government must acquire the most accurate information possible about plans in Makassar to serve the Company's interests. No further instructions were given as to how exactly the High Government should go about improving the Company's position in Makassar. The appreciation of the situation, as well as the specific mode of action was left to the discretion of the High Government. All this aligns well with the tenor of the General Instructions, namely that the High Government was expected to perform within the general framework laid down there and supplemented and elaborated in particular letters by the Directors.

As for choice of action and implementation of policy, the High Government was expected to adjust its approach to the context in situ. The Directors could only provide the general framework in the 1650 Instructions, and give some general advice. Still, the costs of war-both direct military expenditures and the loss of trade-were a worry that made the Directors press for a conclusion of peace..$^{38}$

\section{Implications in the Directors' advice on Makassar, 1650}

The Directors' advice on Makassar in the 1650 Instructions did not explicitly say much more than this: get your share of information and political influence at the expense of the Portuguese and the English. But, in this advice there were two important implications for Batavia's diplomacy towards Makassar. Reducing the influence of other Europeans in Makassar implied undermining their influence at the Makassarese court, and enhancing that of the Company. This could only be achieved by a diplomatic approach that was at least superficially accommodating. An alternative would be to engage the Company's European rivals at sea, but then this would mean the risk of falling out with the Makassarese at the political-diplomatic level. A third option was of course to engage the Makassarese directly in a costly campaign both at sea and on land. The 1650 Instructions remain silent on these options, but the High Government's reflections in the period 1653-55 oscillated among them. The reason lay in the problem of deciding how Makassar's role in the Ambonese rebellion against the Company's monopoly regime should be tackled.

38 Stapel, Het Bongaais Verdrag, 53. 


\section{Section 3: The De Vlaming-Maetsuyker Controversy Concerning When to End the War: the shared pragmatic mode of thinking about overseas diplomacy, and the assumptions in Maetsuyker's "soft approach"}

\section{Section topic and problem}

A disagreement rose between Governor-General Maetsuyker and De Vlaming concerning how and when to end the war with Makassar. De Vlaming's position was that any treaty with Makassar should be based on a military victory. Against this position of "treaty by total victory only" Maetsuyker argued for negotiations as soon as the Makassarese were "ripe for it." This discussion may have started already in fall 1654, when De Vlaming was in Batavia November 1-24, to confer with the High Government, and when he presented a letter to the Directors in which he proposed a strategy for a final victory over Makassar in order to settle the Company's problems with it once and for all.

In this section, I focus on the respective arguments as presented by Maetsuyker in the missive of December $24,1655 .{ }^{39} \mathrm{My}$ aim is twofold: to reconstruct the shared implications of the pro and con arguments for war, and second, to establish the particular characteristics of Maetsuyker's argument in favour of negotiations.

\section{Presentation of the two contestants}

\section{Maetsuyker: Career and historiographic evaluation}

Maetsuyker was legally trained and had practised at the provincial court of Holland. He had been "headhunted" by the Directors as part of a campaign to straighten up corruption and irregularities in the judicial system in Batavia. He left for Batavia in 1636, and was the author of the Bataviasche Statuten. He gained diplomatic experience as envoy to the Portuguese, viceroy in Goa, served as governor of Ceylon, and was appointed director-general before his election and official appointment as governor-general in $1653 .{ }^{40}$ Stapel praises him for his "great capability" and "exceptional political talents," particularly in dealing with local rulers. ${ }^{41}$ 


\section{De Vlaming van Oudshoorn}

Arnold De Vlaming van Oudshoorn was appointed governor of Ambon in 1647. In the view of Stapel and others, he was a man of energy, but little empathy ${ }^{42}$-a man with an "iron fist," 43 or an ijzervreter (swashbuckler) as Blussé calls him. Tellingly, De Vlaming's performance in Ambon drew criticism from Governor-General Van der Lijn who held that he was imposing too much hardship on the local population..$^{44}$ Nonetheless, De Vlaming was the one who was put in charge of suppressing the rebellion in Ambon. In short, he had earned his position and prestige for reasons quite different from Maetsuyker. When De Vlaming openly opposed Maetsuyker's policy, he could do so because of the strong position he had already earned in the service of the Company.

\section{Propositions}

The contrast in Maetsuyker's and De Vlaming's approaches to Makassar may be explained partly by differences in character: Maetsuyker was prudent and calculating, De Vlaming devious and energetic. Such armchair psychological judgement should not overshadow another important factor that reveals itself from a close reading of Maetsuyker's counter-argument to De Vlaming's offensive tactics. It becomes clear that their disagreement was embedded in diverging views on what to expect from the Makassarese, or, more specifically, Hasanuddin's intentions and motives. Maetsuyker believed that Hasanuddin would honour a treaty in which Makassarese non-intervention in the Spice Islands was stated. De Vlaming believed that no matter what the treaty said on this point, the Makassarese would continue to interfere. Diverging appreciation of context conditioned the diverging views on tactics. This is supported by the shift in policy after 1655 , when an appreciation of the sultan's motives and real intentions were reinterpreted in line with De Vlaming's positions, and in 1660, when direct military intervention in combination with opposition from within Makassar itself became promising. ${ }^{45}$

\footnotetext{
42 Ibid. 294.

43 Stapel, Het Bongaais Verdrag, 46.

44 Stapel, Geschiedenis van Nederlandsch Indië, 294.

45 See chapter 6, below.
} 
Although Maetsuyker and De Vlaming started from distinct assumptions and arrived at different conclusions in 1655, both conformed to the pragmatic mode of thinking about overseas diplomacy. No appeal to international law was included in the respective arguments. Both applied a mode of argument that would now be termed a "cost-benefit analysis," as seen from the Company's perspective. Thus, even when Company opinion overseas was split on tactics, it is still possible to reconstruct a shared framework of thought about overseas diplomacy for the two divergent arguments.

\section{Textual analysis, Maetsuyker's advocacy for the negotiation option in the missive of December 24, 1655}

The section on Makassar in the December 24 missive starts by giving some general reasons for the decision to start negotiations. The illicit export of cloves from Makassar had caused the High Government "serious worries." ${ }^{4}$ The High Government did not concur with De Vlaming's proposal "to avoid participation by others... and that the foreigners should be deterred." 47 Such a policy would only provoke increased cultivation of cloves in places unheard of before, ${ }^{48}$ and thus lead to a volume of smuggling that the Company could not possibly contain. ${ }^{49}$ The result would be a heavy draw on the Company's resources from which only the Company's rivals stood to profit. ${ }^{\circ 0}$

It was understood that the third parties reaping the fruits of the imperfect control were the other Europeans, particularly the Portuguese, residing in Makassar. The above argument sums up Maetsuyker's general opposition to De Vlaming's militant approach, which he considered counterproductive in terms of cultivating local goodwill, too costly to be effective, and therefore damaging to the Company's interests.

\footnotetext{
46 “ons in groote becommeringen hout." December 24, 1655, GM 3.5.

47 "Dat om het minste dat iemant anders daarin willen participiren ... de vremdelingen te detereren." December 24, 1655, GM 3.5.

48 "Maer dat deselve door ons groot woelen eer sullen worden waecker gemaeckt om haer totte cultur ende aenplantinge van nagelen te begeven, daer se anders noyt en souden hebben om gedacht."

49 “Te meer om dat ons hetselfde (the smuggling) overal te beletten t'eenemael onmogelijck is." December $24,1655, G M 3.5$.

50 "In welcken gevalle de Compagnie onder de sware lasten sal moeten beswijcken ende andere mette vruchten van deselve doorgaen." December 24, 1655, GM 3.5.
} 


\section{On De Vlaming's excessive use of force as counterproductive in particular}

The suggestion that De Vlaming's hard method was alienating the locals and creating opposition instead of goodwill was further elaborated by Maetsuyker in a separate section. Maetsuyker criticised De Vlaming's excessive use of force, which, according to him, alienated the locals and thus created opposition. He ventured more general considerations on the counter-productivity of using violence in the Moluccas to obtain good relations with Makassar. Maetsuyker then referred to De Vlaming's conduct of operations against Buton and Makassar during the war. The High Government "had wished that his Excellency had not shown up there and had abstained from hostile actions against the city." ${ }^{51}$ This specific reproach was then expanded into a more general deliberation over whether resorting to violence actually was conducive to improving relations with Makassar. Maetsuyker's again argued that it was not; quite the contrary: "Such bravado just caused bitterness and contempt and thus jeopardized the state of peace that was so vital to the Company." ${ }^{2}$ By implication, only tactful negotiations could secure a much-needed peace; provocative actions only worked against it.

\section{The basic assumptions in De Vlaming's argument for prolonged war until total victory}

As we have seen, Maetsuyker presents in essence a cost-benefit analysis, in which the argument against De Vlaming's plan is that the costs of sanctions would exceed the returns. De Vlaming used the same type of reasoning for his pro-war stand, but argued that long-term gains would surpass short-term losses. According to De Vlaming, the Makassarese were not really inclined towards peace..$^{53}$ From this it followed that the Company had "nothing to gain from negotiating a treaty under the present circumstances," 54 that is before a

\footnotetext{
51 "Wij wenschten wel, dat sijne E. daer op die wijse niet en ware verschenen of tenminste op de stadt uytter zee geen hostiliteyt hadde geplecht." December 24, 1655, GM 3.6.

52 "Also diergelijcke bravaden niet dan meerder verbitteringe en connen verwerken, tot verachteringe streckende van de vrede, die de Compagnie soo noodich is." December 24, 1655, GM 3.6.

53 "Geen groote genegenheyt tot vrede en accommodatie van sacken te hebben." December 24, 1655, GM 3.6.

54 “daer geen voordeel voor de Comp.e uyt gesien te connen worden." December 24, 1655, GM 3.6.
} 
total military defeat had been forced upon them. Although the sultan and court proclaimed themselves inclined towards peace, they harboured consistent expansionist ambitions in the Eastern Archipelago. The Company therefore had to be on constant alert for Makassarese aggression in the Spice Islands. ${ }^{55}$

For De Vlaming then, war, whether openly declared or not, was structurally built into the Makassarese-Company rivalry over the Spice Islands. No matter what came out of the negotiations, or whatever the terms of their agreement, the Makassarese would always pose a threat to Banda and Ambon. Therefore, the Company would be obliged to direct resources to defending its interests in the Spice Islands. De Vlaming underscored his position with the cost-benefit argument that future commercial gains would outweigh the cost of war. The big volume of trade passing through Makassar was detrimental to the Company's commercial interests. A military defeat of Makassar would put an end to that. ${ }^{56}$

\section{De Vlaming's cost-benefit argument}

The cost-benefit argument in De Vlaming's argument for a military solution was also illustrative of the long-term expansionist thinking in which today's spending yields tomorrow's profits. In any case, both aspects of the argument are indicative of the primary concern of the Company's commercial balance sheet both in the republic and overseas.

\section{Maetsuyker on De Vlaming's cost-benefit argument for war}

Maetsuyker's counter-argument to war as a means of securing future gains turned De Vlaming's cost-benefit assumptions upside down. War would fall heavier on the Company than on Makassar, which could wage war with fewer costs, claimed Maetsuyker, ${ }^{57}$ supporting his assertion by reference to past

55 "Omdat sij doch echter altijt sowel bij vreede als oorlog hare Oosterse conquesten tegen derselver attentaten sal moeten versekert houden.” December 24, 1655, GM 3.6.

56 "Sijnde besijden dien de vreede met Macassar de negotie tot Batavia schadelijck om de groote vaart, die sij hebben, dewelcke haer moste worden belet.” December 24, 1655, GM 3.6.

57 “die hare oorlogen met seer cleyne costen connen voeren." December 24, 1655, GM 3.6. 
experiences. The Company had paid dearly for its past conflicts with Makassar. ${ }^{58}$ Prolonged war was not a means to increased profit. Instead of spending money on war, Maetsuyker continued, the Company's resources would be more profitably deployed in other projects. ${ }^{59}$

So, sharing the same general pursuit, and within the same framework of reasoning, Maetsuyker flipped De Vlaming's conclusion on its head by a different reckoning of the prospected gains and costs. This difference over approach was not embedded in legal considerations; it was based on diverging assumptions as to what to expect from the Makassarese.

\section{De Vlaming and Maetsuyker on whether to trust the Makassarese}

De Vlaming mentioned unreliability and opportunism as inherent character traits of the Makassarese. They had well proven to be "people that would never wink at breaking their word if it served their own interests." ${ }^{60}$ The Company's prior experience went to prove that: "Each time the Company lowered its guard, the Makassarese seized the opportunity to infringe on Company possessions." ${ }^{61}$ Considering the Company's experience with Makassarese deceit in the past, there were no reasons for trust now.

The divergence in opinion between De Vlaming and Maetsuyker rested on a fundamental difference in belief about Sultan Hasanuddin's trustworthiness. With the conclusion of the 1655 war, a golden opportunity presented itself in which the Company's aims could be achieved by negotiations alone. ${ }^{62}$ This opportunity should not be spoiled by "adventurous war-making." ${ }^{\text {"63 }}$

\footnotetext{
58 "Daer deselve daerentegen de Comp.e soo lastich vallen, gelijck dese jaren genoechsam gebleken sijn." December 24, 1655, GM 3.6.

59 "Behalven dat ondertusschen andere exploiten, daer haer meer voordeel uyt soude connen toevloyen." December 24, 1655, GM 3.6.

60 "Als lieden sijnde, die van het verbreecken van haer wort gants geen werck en sijn maekend, als se daer maer voordeel met connen doen." December 24, 1655, GM 3.6.

61 "Gelijck se t'allen tijde connen, soo haest wij naelaten tegen haer op hoede te sijn ende onse plaetsen met genoeghsame macht beset te houden.” December 24, 1655, GM 3.6

62 December 24, 1655, GM 3.7.

63 "Maer wij oordelen, dat de Comp.e nu haere saecken, God sij lof op soo gewensten voet gebracht sijn ende dat men hoope heeft tot een equitabile vrede te sullen konnen geraken, niet van node en heeft soodanigen hachelijken cans te wagen." December 24, 1655, GM 3.7.
} 


\section{Maetsuyker's counter-arguments to De Vlaming's "grand strategy"}

Maetsuyker declared that ending the war and concluding a peace not only constituted the better option, but were also of vital importance to the Company's interest in the long run. ${ }^{64}$ Continuation of the war would only lead to fanatical, anti-Company sentiment in Makassar; it had to end to "preclude the further spread of illfeeling against the Company." ${ }^{65}$ The argument that prolonged war would entrench a hostile attitude towards the Company was further underlined by the characterisation of the Makassarese as "stubborn and uncompromising." One must therefore be careful not to provoke them. The plausible negative consequences of continued war necessitated a different approach than De Vlaming's provocative use of force.

Neither De Vlaming nor Maetsuyker appealed to legal arguments. Both of them appealed to cultural factors, understood as specific traits of the national character of the Makassarese. De Vlaming argued his position from an assumption of Makassarese ingrained deceit, Maetsuyker from a belief in their sensitivity and pride.

\section{De Vlaming's grand strategy for Makassar rejected-a matter of differing expectations}

The next step in De Vlaming's line of argument was to show how total victory could be obtained. A vital element in his grand strategy was that the Company must encourage local dissent and join forces with local insurgents rising in rebellion against Makassar. He deemed the prospect of finding a local ally who could be used in the interest of the Company good. ${ }^{67}$

Maetsuyker rejected the idea of sowing discontent and division among the Makassarese and so intervening on the side of the rebels on the grounds that it was unrealistic and, moreover, counterproductive in that it would only sow hatred against the Company and foment anti- Company feelings. ${ }^{68}$

\footnotetext{
64 "dat de vrede de Comp.e niet alleen dienstich, maer ten hoognodich is." December 24, 1655, GM 3.6.

65 "Om voor te komen, dat sij haer heyllose concepten niet meerder ernst en comen te vernemen." December 24, 1655, GM 3.6.

66 "gelijck het een obstinate, hertneckige natie is." December 24, 1655, GM 3.6.

67 "dat men bequamelijck twedracht onder de landtsaten soude connen veroorsaecken ende daermet ons voordeel doen." December 24, 1655, GM 3.6-7.

68 "dat eenige gemisconteerende landtsaten dan terstont souden gereet staen met ons te spannen ende tegen de Maccasarse croone op te staen, dat soude t'eenemael op het onseecker gebout sijn. Sijnde eer
} 


\section{Rejecting De Vlaming's war plan as costly, reckless and likely counterproductive-advocating soft diplomacy as an alternative}

De Vlaming's war-plan was simple and bold, namely to attack the southernmost Makassarese forts with 1,200 troops, 600 from Batavia and the rest from Ambon and Banda. All were to land "with a clear dedication to either conquering or perishing." ${ }^{69}$ Maetsuyker, however, found De Vlaming's war plan not only costly and reckless, but also counterproductive. Typically, Maetsuyker's counter-argument started with a tactical consideration on the lack of realism in De Vlaming's plan. Prospects of success were deemed bleak because sowing discontent and tying up with local allies would be difficult as long as the Company did not have "a firm foot on land." ${ }^{\circ}$

\section{Opposing De Vlaming's grand strategy for its lack of long-term realism}

Added to the conviction that the present situation greatly favoured a settlement by negotiation was Maetsuyker's opinion that De Vlaming grossly underestimated the risks involved in settling the issues with Makassar by continuing the war. First, the transfer of troops from Banda and Ambon would jeopardise the security of these "valuable possessions" so that the "enemy would meet an open door to go about as he liked." ${ }^{71}$ Second, even if the war was successful and the Makassarese forts fell into the Company's possession, the Company's limited resources would prevent it from holding them for long. The sheer number of the Makassarese fighting men, their fighting spirit, and their swiftness of mobilisation spoke overwhelmingly against it. ${ }^{72}$ Lack of military realism and

te gelooven dat sij, haer van een uytheemse ende Christenen vijandt op haere eygen bodem besprongen siende, sich te vaster met den ander souden verbinden om denselven met gemene macht van het landt te drijven, gelijk men dat veeltijds soo heeft sien geschieden.” December 24, 1655, GM 3.7

"met resolutie te overwinnen of daer alle te sterven." December 24, 1655, GM 3.7.

70 "hetselve beswaerlick sal wesen in 't werk te stellen, tensij alvooren voet op het landt hebben." December $24,1655, G M 3.7$.

71 "ende de viandt bij verlies van soodanigen getal crijghsvolck een deur geopent om in deselve te gaan grasseren na sijn geliefte." December 24, 1655, GM 3.7.

72 "Ende genomen, den aenslach quam al te gelucken ende wij wierden van hetselve casteel meester, wat hoope om hetselve in te houden tegen de macht van soo menighte duysenden seer moedige menschen 
long-term strategic thinking were thus Maetsuyker's main arguments against De Vlaming's grand strategy.

\section{Arguing the lack of realism in the belief in obtaining local allies}

Maetsuyker logically discredited De Vlaming's belief in obtaining local allies within Makassar itself. In fact, De Vlaming's assumptions were reversed. First, Maetsuyker and the High Government repeated their view that finding allies among local rebels was highly uncertain. ${ }^{73}$ Then they drew up a contrary scenario as the more likely outcome of involvement by the Company, namely that the people of South Celebes would join ranks and be even more united in an attack by a Christian nation. ${ }^{74}$ They concluded their argument by pointing out that this had been the prior experience with Makassarese internal mobilisation in the face of external aggression. ${ }^{75}$

Far from doctrinal legal arguments, the criticism of De Vlaming's policy and defence of the negotiation option were formulated on basis of the nature of the Makassarese, their traits, and empirical, historical experience. The argument represented a form of realist tactical thinking; in a word, it was pragmatic. Having pointed that out, one should note the respective assumptions about the Makassarese.

Maetsuyker and the Council implicitly characterised De Vlaming's approach as "military adventurism." But, significantly neither party clearly labelled their own or their opponent's position. Rather, they both assessed the situation in Makassar and weighed the options for Company action from a practical point of view. Maetsuyker's and De Vlaming's disagreement was one over means,

als den Macassar in minder dan een uyr tijts tegen ons soude connen op de been brengen." December 24, 1655, GM 3.7.

73 "dat eenige gemisconteerde landsaten dan terstont souden gereet staen met ons aen te spannen ende tegen de Macassarese croone op te staen, dat sou 'teenemael op het onseecker gebout sijn." December $24,1655, G M 3.7$.

74 "Sijnde eer te geloven, dat sij, haer van een uytheemsen ende Christen vijandt op haren eygen boden besprongen siende, sich te vaster met den ander souden verbinden om denselven met gemene macht van het landt te verdrijven." December 24, 1655, GM 3.7. "gelijck men dat veeltijds soo heeft sien geschieden." December 24, 1655, GM 3.7. 
and rested on diametrically opposing convictions about whether Hasanuddin could be trusted or not.

\section{Arguing permanent residency and information gathering by way of treaty as opposed to war}

Maetsuyker's diplomatic approach aimed for a negotiated peace that would provide the Company permanent residency and thus better access to information about goings-on in Makassar. The reasoning went like this: By obtaining a peace treaty without provoking the Makassarese into defiance, the Company would be granted a permanent establishment in Makassar and better access to information about Makassarese politics in the Eastern Archipelago. The need for keeping an enlarged garrison in the eastern quarters would be eliminated by the permanent residency of Company servants in Makassar itself, because based on the information by the Company's resident, resources and men could be transferred to Banda and Ambon when needed. ${ }^{7}$

Probably as a pre-emptive move against De Vlaming's argument that the Makassarese could not be trusted regardless of what they might agree on in writing, Maetsuyker went on to say that reliable information could be obtained, even if the rulers of Makassar must be deemed "the most civil and discreet of all Moorish princes in these quarters." 77 In brief, the argument against De Vlaming's proposal for strengthening the Company's military resources in Banda and Ambon on a permanent basis was that permanent residency in Makassar would "do the trick," and at a lower cost. Once again, this was a shared goal through different means, and put forward in practical, not ideological, terms.

\section{The concluding appeal to the Directors}

The Council's point-by-point refutation of De Vlaming's arguments for war ended with an appeal to the Heeren XVII that it shared a clear and unqualified

76 "Ende waneer wij weder een residentie in Macassar nemen, gelijck, soo de vrede getroffen wort, sal dienen te geschieden, soo sullen wij door middel van deselve altijt een oogh in 't seyl connen houden ende van haer doen en ondernenen tijdich advijs hebben om ons van te dienen ende in ' $t$ versorgen van deselve provintiën na te reguleren." December 24, 1655, GM 3.6.

"Behalven dat die van Macassar altijt gehouden sijn geworden wel de civielste ende discreetste te sijn van alle de Moorse vorsten, hier omtrent gelegen." December 24, 1655, GM 3.6. 
conviction that negotiation would best serve the Company's interests under the current circumstances. The credibility of the negotiation option rested on the premise that after years of warfare, in the fall of 1655 there was a sincere Makassarese wish for an enduring peace. This basic assumption was argued in contextual terms, namely that "Given the Makassarese lack of success over the last years, it is to be hoped that they had learnt the lesson not to once again 'stick their noses' into matters that were none of their business. Their interference so far had gained them nothing but had cost them a lot." ${ }^{78}$

The message to the Directors was clear: Now was the time for negotiations, not provocations. It was, in fact, an opportunity that the High Government already had seized by approaching Hasanuddin for a treaty. ${ }^{79}$ The argument for the negotiation option had come full circle. The centre of that circle was a conditional trust in Hasanuddin.

The High Government believed an acceptable, negotiated solution to be imminently at hand. ${ }^{80}$ As the final decision on whether to employ De Vlaming's hard-line or the diplomatic approach lay with the Directors, Maetsuyker underlined, he awaited and would follow the Directors' further instructions. ${ }^{81}$ Still there could be no doubt about the governor-general's preference: He had already sent Van der Beeck for negotiations to Hasanuddin's court.

\section{Considerations of context primary to considerations of law}

Judged by the standards of international law in Europe at the time, De Vlaming's grand strategy represented a clear breach of the rules since his plan involved outside interference in the internal affairs of a sovereign state. If Andaya's proposition about the doctrinaire legalistic obsession of VOC diplomacy were correct, one would expect some comments on the legal dimension on this

78 "Sijnde te verhopen, dat den Macassar door de quade successen, die hij in dese laeste jaren heeft behaelt, de lust oock sal sijn vergaen om voorerst hem weder te steecken in saecken, hem geensints raekende ende die hem tot noch toe geen voordeel, maer wel groote schade hebben toegebracht." December 24, 1655, GM 3.7.

79 December 24, 1655, GM 3.8 .

80 "Invoegen dat wij van geloven blijven dat de Compagniee in alle maniere de vrede, soo daer onder goede conditiën toe comen can, behoort te amplecteren om eens een een eynde van dien lastigen oorlogh te maecken." December 24, 1655, GM 3.7.

81 "ondertusschen daerop afwachten de ordre die U Ed. Ons dienangaende sullen gelieven te geven." December 24, 1655, GM 3.5. 
point. But legal considerations were not mentioned in Maetsuyker's counterargument to De Vlaming's original proposition. Practical considerations as to chances of success were what mattered. Both men argued within a shared pragmatic framework; their difference lay in the prospects of success for their respective proposals.

\section{The significance of dismantled trust after 1655 and its significance in interpreting the 1655 context}

In De Vlaming's version of "divide and rule" as applied to Makassar, we might see embryonic features of a "greater scheme" for restructuring the political geography of South Sulawesi. As we know, this was what did take place after the joint Bugis-Company victory in the 1667 war. De Vlaming's grand strategy came to mature in the five years after 1655, to reach a full explication in the missive of December 1660, when it was at last presented as a viable option. In fact, the Makassarese's continued infringement in the Spice Islands and fluctuations of opportunity for the Company's direct intervention in Makassar came to dictate a continued discussion and drove opinion in Batavia towards a military approach.

But in 1655, Maetsuyker still favoured negotiations based on his trust in Hasanuddin's sincere intention for a lasting peace, and a commitment to noninterference in the eastern quarters.

\section{Opposing standpoints within a shared conceptual framework-the source of differences in policy preferences}

As we have seen, none of the policy preferences were argued with reference to law. Both sides considered the problem with an eye to costs and benefits. Both sides considered their choice of tactics in terms of the overall context and pragmatism, not on basis of legal principals. The question remains, however, as to how much the above-sketched divergence in opinion could be explained by differences in personality.

There is a recurring trait in the historiography to ascribe differences in the formulation and execution of policy to differences in personality. Maetsuyker's approach is thus explained by his being a "cautious person," 
while De Vlaming is judged a "man of action." ${ }^{22}$ This might reflect a difference in temperament, yet the evidence of their arguments suggests that what really divided them were their different assumptions about possible outcomes. The difference between Maetsuyker's and De Vlaming's positions was marked more by diverging perceptions of the situation at hand than in psychologically fixed policy preferences. I stress this point because when we come to the period after 1655, Maetsuyker gradually came to express points of view and arguments that were closer to De Vlaming's in 1655. It would be irrational to assume that Maetsuyker changed personality after 1655 . His appreciation of Hasanuddin as a trustworthy treaty partner did change, and, consequently, so did his view about what constituted an appropriate policy. Too much emphasis on personality in the analysis of diplomatic behaviour may lead us to underappreciate historical context and the role of learning by experience.

The lesson of the disagreement between De Vlaming and Maetsuyker in 1655 and the later shift in policy demonstrates on the one hand that deliberations on policy in Batavia were remarkably vivid, and that policymaking was dynamic. Both features deny fixity to legal principles or fixed personality traits as prime determining factors in policy deliberations and decisions. Both features were illustrative of a pragmatic approach. The determining factor was an appreciation of the situation on the ground. In 1655, Maetsuyker still deemed that the sultan's behaviour warranted a soft approach. That was also the defining trait of the December 28, 1655, treaty.

\section{Section 4: Analysis of the 1655 treaty as a typical product of "soft diplomacy"}

\section{Historiographic positions}

Arguing from his "non-Eurocentric" point of view, Andaya holds that the 1655 treaty "clearly demonstrates the influence of treaty making" and that its contents "read like a typical South Sulawesian treaty." ${ }^{83}$ Then again, taking

\footnotetext{
82 Maetsuyker would not use the sword as long as there was another way out, while De Vaming's fury was "repudiated"; Stapel, Geschiedenis van Indië, 338 and 306.

83 Andaya, "Treaty Conceptions and Misconceptions," 287.
} 
the whole treaty body into account, this was an exception. ${ }^{84}$ Seen from theCompany's perspective, the 1655 treaty came to be judged in rather harsh terms, both by contemporaries, and by later Dutch historians, particularly on the grounds of the concessions made to Hasanuddin. ${ }^{85}$ But it remains a fact that the treaty to which Van der Beeck agreed in Makassar on December 28 was countersigned in Batavia on February 2, 1656. ${ }^{86}$

\section{Propositions, analysis of the 1655 treaty}

I present a somewhat different view of the 1655 treaty. As for Andaya's proposition of its "typical" South Sulawesian nature, a good argument can be made to the contrary, namely that the Company's concessions to Makassar can be read as specific regulations protecting Makassarese interests, in other words that they were conceived in a framework of secular power politics. Seen from the Company's side, although the treaty was made as result of pressure for peace from the Netherlands, it can just as well be considered an exemplary product of the "soft diplomacy" advocated by Maetsuyker. That is my proposition. Hence, I aim to demonstrate that the wording and regulations in the 1655 treaty were wholly consistent with the basic policy assumption held by Maetsuyker at the time, namely that Hasanuddin would indeed ban Makassarese sailings to the Spice Islands. Thus, the governor-general and Council's later criticism of both the treaty's terms and Van der Beeck's performance in Makassar should be seen in the light of a shift in thinking a year later, ${ }^{87}$ when these optimistic assumptions turned out to be wrong. ${ }^{88}$ The concessions made by the Company in the 1655 treaty made perfect sense considering that the Company obtained acknowledgement by Hasanuddin that Makassarese should stay out of the Spice Islands, and that the Company was free to handle third parties who broke the sailing ban at its own discretion. ${ }^{89}$

\footnotetext{
84 Ibid. $287-88$.

85 See for instance Valentijn, Beschryvinge van Oost Indiën, 1.322 and Stapel, Het Bongaais Verdrag, 54 referring also to Speelman's negative evaluation of it.

86 Stapel, Het Bongaais Verdrag, 53.

87 See below.

88 See chapter 6 for elaboration.

89 See analysis below.
} 


\section{Textual analysis}

One of the most telling parts of the 1655 treaty $^{90}$ is the preamble in which Sultan Hasanuddin presents the background and general conditions for the agreement. After having stated who the treaty parties are, ${ }^{91}$ he places the initiative for peace with the Company. The treaty has been concluded "because the governor-general is inclined towards peace." 92 His own reasons for an agreement with the Company Hasanuddin depicts as a necessity due to the imbalance in strength between him and the Company. ${ }^{93} \mathrm{He}$ has agreed to the peace because "the governor-general is a strong and powerful man"94 while he himself, "is so much inferior in strength and power."95 The message is clear: it is the Company who has approached Hasanuddin with an offer for peace, and the sultan, considering his relative weakness, has no other option than to accept. But at the end of the preamble, he states he has managed to secure a treaty that does no harm by rhetorically asking "should I not agree to a peace that clearly implies no harm to my people and subjects." ${ }^{\text {96 }}$

\section{Comments, Preamble}

The inclusion of Hasanuddin's wish for the Company to stand out as the party asking for peace might have been perceived as a face-saving device addressed to the sultan's home audience with no serious consequence for the Company. The transaction of prestige involved here represented a concession that the Company could afford. Given the High Government's willingness to please Hasanuddin on this point, it seems reasonable to believe that the sultan's ambiguous remarks on the peace as being forced on him because of his relative weakness, was accepted for the same reason. The transaction was however counterbalanced by Hasanuddin's positive depiction of the peace at the end of the preamble. He had agreed to a treaty that was not harmful to his people. My

\footnotetext{
90 I follow the text as reproduced in the Corpus Diplomaticum, 2.82-84.

91 The ruler of Goa and Lord of Tello and Ambassador Van Der Beeck on behalf of the Company, Corpus Diplomaticum, 2.82.

92 "Om dat den Gouverneuir Generael will vrede maken." Corpus Diplomaticum, 2.82.

93 As was done by Alauddin in 1637, see chapter 3.

94 "en een groodt man is ende sterck." Corpus Diplomaticum, 2.82.

95 "ende ik, die zoo veell cleiner ben en onmaghtigh." Corpus Diplomaticum, 2.82.

96 "Zoude ick geen vreede maeken wanneer geen quadt aen onse onderdanen doet." Corpus Diplomaticum, 2.82 .
} 
point is That, with the possible exception of his remark about his relative inferior strength, Hasanuddin's presentation of the treaty has as much to do with concerns of secular power as with traditional South Sulawesian concepts of symbolic power.

Seen from the Company's side, both the transfer of prestige to Hasanuddin and the expressed ambiguity about the peace itself were tactical concessions that the High Government could accept as long as it obtained a formal declaration of commitment to stay out of the Moluccas from the Makassarese. Hasanuddin's trustworthiness on this point was, as we have seen, what Maetsuyker had consistently argued for in his rejection of De Vlaming's hard-line approach in 1655.

\section{Concessions}

If Dutch concessions could be made on presumably insubstantial issues such as Hasanuddin's prestige in Makassar, making them on regulations that could well be interpreted as creating loopholes in the Company's privileges in the Spice Islands was another matter. Yet the 1655 treaty was full of such. The first clause, for instance, confirmed that the sultan's subjects still residing in Ambon should be allowed to return to Makassar. ${ }^{97}$ Most of these were people who had taken part in the rebellion against the Company in Ambon..$^{98}$ Articles 2, 3, 4, and 5, all offered loopholes in the ban on Makassarese sailings to the Spice Islands on religious grounds. The Makassarese appeal to religion was probably why the High Government accepted them, thinking them insubstantial. But for the Makassarese, this appeal may well have been interwoven with, and thus have served, political purposes. I shall analyse these articles in detail to highlight the function as well as the probable thinking behind the Company's acceptance of them.

\section{Article 2, 1655 treaty}

The second article in the treaty allowed Muslims residing in Ambon to sail to Makassar: "all Muslims wishing to go to Makassar should be allowed to do so." ${ }^{99}$ The explicit rationale for the concession, clearly coming from Hasanuddin,

971655 treaty, art. 1, Corpus Diplomaticum, 2.82.

98 Corpus Diplomaticum, 2.82, n5.

99 "Dat alle Mooren, die met haren vrije will near Maccassar willen, hem zullen toegestaen werden." 1655 treaty, art. 2, Corpus Diplomaticum, 2.83. 
was presented in terms of religion in the following manner: "According to the Makassarese Religion it would be a grave sin to leave them [i.e., the Muslims in Ambon] in Christian custody."

Heeres regards the Company's agreement to open up for traffic of Muslims from Ambon to Makassar as a "dangerous concession," since some the Ternatese and Ambonese would qualify as "Muslim." ${ }^{101}$ The concession would only appear to be dangerous assuming that Hasanuddin harboured expansionist or aggressive plans. The prevailing thinking in Batavia at the time was that he did not. ${ }^{102}$ It is more likely that the High Government interpreted Hasanuddin's request for the exception regarding the free trafficking of fellow Muslims as another quest for prestige, this time with a religious twist. If so, the High Government was acting on assumptions that fall within Andaya's perception of the symbolic or metaphysical nature of South Sulawesian diplomacy. Contrary to Andaya's assumptions about Company diplomacy then, it was not acting on principles of international law, but, rightly or wrongly, on perceptions of local context and culture.

Goals and means in Makassarese and Batavian policy may not have been identical, but their power politics overlapped. As long as both parties laid claims to influence and sovereignty in the same territory, in the end the agreement had to fail. But if in 1655 the High Government assumed that prestige recognition for internal use was Hasanuddin's primary motive, this could well be traded against guaranties for the Company's monopoly rights. I think such assumptions go a long way to explain all the concessions made in the 1655 treaty.

\section{Articles 3 and 4}

Another concession that was also based on Makassar's role as a protector of its co-religionists was made in article 3, which simply states that none of the Muslims in Ambon would be punished. ${ }^{103}$ In effect, the article offers a de facto general amnesty to the rebels. Once again, this was a Makassarese claim that

\footnotetext{
100 "om dat het voor haer weens hare religie een groodte gesonde i, die onder de Christenen te laten." Corpus Diplomaticum, 2.83 .

101 Corpus Diplomaticum, 2.83, n2.

102 See the foregoing discussion of Maetsuyker's advocasy for the soft diplomacy approach.

103 "Dat alle de Moren, die in Ambon zijn, niet sullen gestraft zijn." 1655 treaty, art. 3, Corpus Diplomaticum, 2.83.
} 
could be explained by motives of prestige, and in that light the concession made perfect sense given the belief that Makassar would from now on not interfere in matters relating to Ambon. Continued contact between Makassar and Ambon was also implied in the following article, which concerned the sultan's right to collect his debts in Ambon. ${ }^{104}$ As in the above, the concession must be explained as part of a "good faith" attitude on behalf of the Company.

\section{Article 5}

In article 5, which concerned the exchange of prisoners, Hasanuddin achieved another advantage with an agreement for the exchange of prisoners: all prisoners being held in Batavia should be returned to Hasanuddin, as likewise all Company prisoners held by Hasanuddin should be returned by him, except those who had converted while in Hasanuddin's custody. ${ }^{105}$ This was still another concession to Hasanuddin made for religious reasons. Again, there is every reason to believe that the High Government primarily regarded this as a pure prestige transaction, and thus of secondary significance.

\section{A brief speculation on Hasanuddin's use of the religious argument in articles 2-5}

If Hasanuddin was appealing to his role as defender of the faith for secular reasons and simply to buy time, as there is reason to believe judging by his later actions, there is every reason to admire his manoeuvring in 1655 . The sultan succeeded in creating loopholes in the treaty to protect his own power position in the Eastern Archipelago by "playing the religious card."

This interpretation, however, implies that Hasanuddin's tactics were not based on the South Sulawesi treaty tradition à la Andaya, but that he exploited the Dutch assumptions that he was in pursuit of religious prestige. A feeling of having been outsmarted in 1655 may help explain Batavia's uncompromising tone in its later hard-line approach. ${ }^{106}$

\footnotetext{
104 "Dat den Coningh zijn schulden, die in Ambon heft uijtstaende, zall mogen doen inmanen." 1655 treaty, art. 4, Corpus Diplomaticum, 2.93.

105 "Excepto die Moorse gewerden zijn." 1655 treaty, art. 5, Corpus Diplomaticum, 2.83.

106 See chapter 6.
} 


\section{Prestige and religion as motives in Company diplomacy}

In maritime Southeast Asia, the Company obviously was a Christian intruder in an environment in which Islam was dominant. This meant that local powers could always appeal to religion as a mobilising force against the Company. One should not, however, underestimate the psychological role of religion as an identity-marker for the Company. But it may have taken the form of the merger between Company honour and divine providence, as I have found in the General Instructions. ${ }^{107}$ Makassar and Batavia differed not in whether, but in the degree to which they used religion to mobilise their supporters. In any case, in the August 1660 treaty, which was negotiated from a different balance of power, the 1655 ruling on converts was reversed, although with qualifications. ${ }^{108} \mathrm{~A}$ parallel instance on reversal with respect to the issue of converts is also found in the negotiations and contracts with Banten in 1659 and 1684. In 1659, Maetsuyker conceded that two converted former Company servants could stay in Banten. ${ }^{109}$ In 1684 , in a situation where the tables had turned completely, the ruling was reversed. ${ }^{110}$ Viewed in this light, it seems reasonable to assume that the concession made with Makassar in 1655 on the issue of converts was not made with a light hand, but made from the conviction that the issue was secondary and must be subsumed to the strategic goal of getting a viable treaty at last.

\section{Articles 6 and 7: Regulating relations with the Portuguese and other third parties}

Article 5 represented the final modification of the Company's monopoly and sovereignty in the Spice Islands. The Company's privileged position in the Spice Islands itself was confirmed in the final article of the treaty, article 8 . The two articles in between concerned how Makassar and the Company should act in relation to the Portuguese and other third parties in general. It is important to note that as we turn from bilateral to multilateral relations from article 5 onwards, the terms in the treaty increasingly favour the Company.

\footnotetext{
107 See chapter 3.

108 See chapter 6 .

109 See treaty with Banten, art. 1, Corpus Diplomaticum, 2.156.

110 See treaty with Banten, art. 6, Corpus Diplomaticum, 3.340.
} 
Regarding the issue of the Portuguese, the regulation was closer to a draw than a win for either party. Article 6 simply stated that "The Company's enemies should not be regarded as the king's enemies." ${ }^{111}$ For one thing, this meant that the Company's aspirations to oust and replace the Portuguese in Makassar were blocked. On the other hand, although only by implication, the Company was still free to fight the Portuguese anywhere else. Still, the reality was that the continued Portuguese presence in Makassar implied continued smuggling with the Spice Islands. In article 7, the recognition of Makassar's autonomy in its policy towards the Portuguese was extended to apply to a general autonomy in its relations with all third-party actors "below the winds." ${ }^{112}$

\section{Comments on the regulation of the Makassar- Company positions in the multilateral interaction regime set down in articles 6 and 7}

It may seem puzzling that the Company, having gained the upper hand in war, not only made serious concessions regarding continued contact between Makassar and Ambon but also agreed to terms that guaranteed full autonomy for Makassar's foreign policy. One factor was the pressure for peace from the Netherlands. Nor can the blame be put on Van der Beeck's poor negotiating performance, because the treaty was, after all, countersigned in Batavia. A better explanation is to regard this puzzle as one that primarily arises in a realist and hard-line frame of thought.

Viewed in the idealistic, soft diplomacy approach of 1655 , the concessions made to Makassar all made perfect sense. Makassar got no more than the standard rights prescribed by category 3 of the General Instructions of 1650. The concessions made were the price to be paid for what the Company got in the final article of the treaty, namely Makassarese recognition of the Company's monopoly and sovereignty in the Spice Islands.

\footnotetext{
111 "Dat de vijanden van d'E. Compagnie des Conings vijanden niet sullen wesen." 1655 treaty, art. 6, Corpus Diplomaticum, 2.83 .

112 "Dat zoo den Coningh met dese off gene natien benedenwints in questie (is), dat d'E. Compagnie haer daermede niet sall mogen bemoeijen." 1655 treaty, art. 7, Corpus Diplomaticum, 2.83.
} 


\section{Securing the Company's monopoly and Sovereignty by treaty: Article 8}

The first part of the eighth and concluding article of the 1655 treaty reads "The Honourable Willhelm van der Beeck requests of the king that no Makassarese, nor subjects of the king, be allowed to sail to Ambon, Banda or Ternate." ${ }^{113}$

This was what the Company's envoys had come for in the first place, the issue on which the Company would not concede. Still it was phrased as a "request." The phrasing clearly entailed yet another prestige transaction and once again in favour of Hasanuddin. But that was in line with the general tenor of the treaty as such.

Still more was working in Hasanuddin's favour in the content and wording of Article 8. The "request" was also modified by the qualification that the sultan could be held responsible for his own subjects, ${ }^{114}$ but that he could not ban the sailing of the many foreign subjects residing in his country. ${ }^{115}$ Even so, the Company was recognised as free to deal with such third parties as it might please. This was put in the voice of the Company: "But if we [the Company] should catch them [the non-Makassarese intruders, we] are free to detain and handle them at our own discretion" ${ }^{116}$ The Company's liberty in this matter was further emphasised by a confirmation that such sanctions would "neither be considered a breach of the peace, nor would the sultan look upon them in anger." ${ }^{117}$ In other words, the Company's exercise of sanctions against third-party infringement of its rights in the Moluccas was not to be regarded as a cause for war.

\section{The conclusion of the 1655 treaty}

From the Company's viewpoint, article 8 was the crux of the 1655 treaty. It fulfilled the High Government's primary aim at the time, as it guaranteed Makassarese recognition of the Company's commercial and political rights in

113 “D’H Willhelm van der Beeck versoekt op den Coningh datter geen Maccassaresen offte andere natien, onderdanen van de Coningh, near Amboijna, Banda offte Ternaten sullen mogen varen.” 1655 treaty, art. 8, Corpus Diplomaticum, 2.83.

114 “dat hij zijn volk can inhouden." 1655 treaty, art. 8, Corpus Diplomaticum, 2.83.

115 "maer dat hij veell vremdelingen en coopluyden in sijn landt hadt, die hij t varen niet can verbieden." 1655 treaty, art. 8, Corpus Diplomaticum, 2.83-84.

116 "maer zoo wij desellve connen crijgen, mogen vrijelijck nemen ende daermede handelen, sulx als wij cunnen.” 1655 treaty, art. 8, Corpus Diplomaticum, 2.84 .

117 "soo en sall 't noghtans dese vrede niet verbreeken ende sall den Coningh daerom niet quat wesen." 1655 treaty, art. 8, Corpus Diplomaticum, 2.84. 
the Moluccas, obligated the Makassarese not to interfere, and guaranteed the Company's right to prevent third parties from doing so. These were Batavia's primary aims in 1655, and securing these goals was what made the treaty acceptable. Maetsuyker's stand on this must have rested on his belief that Hasanuddin would honour the rulings of article 8, and not misuse the concessions he gained in articles 1 through 5 . None of this came true, but it was the basic assumption upon which the 1655 treaty rested. Given this background, it seems fair to say that later historians have either misunderstood or too harshly judged the 1655 treaty. At the least it deserves to be considered in terms of the assumptions from which it sprang.

\section{Chapter conclusion}

The 1655 treaty and regulations make perfect sense within the framework of a soft diplomacy approach in which the defence and protection of the Company's possession of the Spice Islands was the primary goal. It sprang from a conviction that the context and the Company's position were such that more ambitious plans were unrealistic, too costly, and otherwise counter to the Company's interests. Considering that Hasanuddin would no longer interfere with the Company's interests in the Spice Islands, a negotiated peace was the better option. Maetsuyker's positions and policies in 1655 were part and parcel of a pragmatic diplomatic approach, built on trust and good faith. 
6

\section{The Pragmatic Dynamics}

of the Batavian Diplomatic

Mode-Shifts and

Fluctuations in the High

Government's Approach

towards Makassar as

Presented in the Generale

Missiven, 1656-61

\section{Section 1: Introduction to the chapter topic}

The difference in opinion between Maetsuyker and De Vlaming in 1655 originated, as we have seen, from diverging appreciations of Sultan Hasanuddin's intentions. In the period after the conclusion of the 1655 treaty up to the war in 1660 however, there was a shift towards De Vlaming's position that Hasanuddin was inherently untrustworthy. The actual choice of policy was predominantly determined by the logic of the situation. This chapter analyses the shift in policy assumptions from 1656 and the reasons behind the fluctuations in policy decisions as they can be read from the High Government's presentation of them in the Generale Missiven in the period after 1656 until 1661.

Although policy recommendations between 1656 and 1660 fluctuated between accommodation and intervention, the basic underlying assumption for 
both positions marked a break in that there was now little left of the trust in Hasanuddin that had been the basis of the 1655 treaty. This meant that negotiations were increasingly regarded in purely tactical terms. The restructuring of the political order in South Sulawesi by military intervention increasingly came to be viewed as the optimal solution to the Company's problems with Makassar. In 1659, a situation arose in which the prospects of setting forth De Vlaming's grand strategy of 1655 looked promising. As this situation subsided, the arguments against military intervention in conjunction with an internal rebellion were not precisely the same as in 1655 . Instead of claiming the absolute impracticality of implementation, the counter-argument implicitly added "for the time being," that is postponing it until favourable conditions would again arise.

The High Government asserted that this shift of thinking was forced on the Company by Hasanuddin's devious manoeuvres and continued aggressive schemes for the Spice Islands. There was clearly an element of "selling" the argument to the Directors, who always regarded war as a last resort. But, there can be no doubt that Hasanuddin's claims to his rights to sail to the Spice Islands, and his exercise of that right after the conclusion of the 1655 treaty, formed the basis for a break with the 1655 assumptions as well as the revitalisation of the grand strategy for Makassar.

\section{Contextual considerations and factors}

Besides the internal unrest caused by the Bugis rebellion, attention also had to be paid to affairs outside Sulawesi and the Moluccas. In the period 1659-60, one of the most pressing issues for the High Government was Ceylon. At the end of June 1658, the Portuguese gave up their last fort in Ceylon ${ }^{1}$ and the Company had seemingly broken Portuguese power on the island for good. But the Company soon faced war with their former ally, Raja Singha. ${ }^{2}$

In 1658 , the Company had also ousted the Portuguese both in Coromandel and Malabar, ${ }^{3}$ but with the outbreak of war between the Company and Raja Singha, the Portuguese were quick to use the opportunity for their benefit, launching an offensive against the Company in Malabar with success. ${ }^{4}$ The peace with Makassar in August 1660, however, freed troops for

\footnotetext{
Stapel, Geschiedenis van Nederlandsch Indië, 318.

Ibid. 321.

Ibid. 319 .

Ibid. 321 .
} 
engagements both in Ceylon and against the Portuguese. ${ }^{5}$ One must infer that the Company's challenges in both Ceylon and Malabar in 1659-60 made concluding a peace with Makassar a more tempting alternative to prolonging the war.

But there were also other factors that may have both distracted the High Government's attention from Makassar, or made peace seem an alluring alternative. Aceh was one such factor. The period between a peace treaty agreed in December 1655 and one concluded in June $1659^{6}$ saw both Company blockades of the Aceh roadstead and a military expedition against the sultanate. ${ }^{7}$

Probably more alarming were developments in China and their implications for the Company's position in Taiwan. As in 1655, the concern was about the war between the advancing Manchu forces and Ming loyalists in Southern China. The leader of the resisting warlords of the southern provinces was the famous Coxinga. In a letter to the High Government in early 1660, the Dutch governor of Taiwan, Frederick Coyet, reported on rumours that Coxinga harboured plans to evacuate to Taiwan because he could no longer withstand the Manchus, and that a number of Chinese on the island were already in his service and supplying him with information. ${ }^{8}$ This cannot but have increased the tension in Batavia and increased its wish for a conclusion of the war against Makassar.

So, all in all, if circumstances in South Sulawesi at one point seemed to offer the Company a complete solution to its problems with Makassar, there were clearly circumstances outside the Moluccas that weighed against it.

\section{Propositions}

My main propositions are that as trust in Hasanuddin decreased the attraction of De Vlaming's original "grand strategy" increased. Shifts in attitude towards Hasanuddin meant that "negotiations" and negotiated revisions to the treaty on symmetrical terms came to be looked on in Batavia as secondary to waiting for an opportunity to force a "final showdown." The political reordering of South Sulawesi by military intervention came to be viewed as the instrument by which a viable solution of the Makassarese problem could be finally achieved. Whereas the missive of December 24, 1655 had advocated negotiation with no goal beyond

Ibid. 322 .

Ibid. 356 and 358 , respectively.

Ibid. $357-58$.

Ibid. 366 . 
getting an optimal treaty that of December 16, 1660 advocated transforming the political geography of South Sulawesi as the one and only means that could establish a lasting solution to the problems with Makassar.

In this process, the meanings of "negotiations," "treaty," and "war" were readjusted. Negotiations were grounded in the lack of opportunity and a means to implement the grand strategy - that is in the absence of a powerful local ally. Whenever there were prospects of such an alliance appeared, so did advocacy for the grand strategy. This all goes to corroborate my general proposition that the High Government's diplomatic thinking was pragmatic through and through, and not driven by European preconceptions of international law. The aim of this chapter is to show that the pragmatism was dynamic and grounded in considerations of local context and situation.

\section{Focus and plan of exposition}

The High Government's presentation of policy deliberations and decisions concerning Makassar in the Generale missiven between 1656 and 1660 forms the topic of the present chapter and I discuss these presentations in chronological order. The analysis is focused on the way policy options and decisions were argued to explicate both the mode of thinking as well as the emotions involved. At the beginning of the analysis of each respective missive I review events that are relevant to understanding the context for the issues raised and the approach argued. This introductory section is followed by a close reading of the text itself. At the end of my analysis of each missiven, I comment on the relationship between the text and historical context. Many of the events treated here will be analysed in a broader context and greater detail in chapters 6 and 7. However, those chapters analyse Batavia's diplomatic posture towards Makassar. In the present chapter, I deal with the dynamics of Batavia's perception of diplomacy towards Makassar between 1655 and 1660 as presented by the High Government to the Directors in the Netherlands.

\section{Comments on the sources}

As the primary sources here are letters from the Generale Missiven, the same general source critical warnings given in chapter 4 apply: they should be read with an eye to how Batavia sought to please the Directors. Between 1655 and 1661, Maetsuyker signed reports in which the assumptions and positions regarding Makassar ran contrary to his earlier views of 1655 . That and the fact 
that Batavia after 1655 came to endorse an offensive policy, which in general was not to the Directors' liking, goes a long way to explain why the arguments and their respective assumptions are so thoroughly worked out. In that quality, they make excellent material for the study of the language of legitimating a form of overseas diplomacy. As for the general chronology of events, I rely mainly on Stapel's 1922 thesis, Het Bongaais Verdrag (The Bongaya treaty).

\section{Section 2: The missive of December 4, 1656-blaming Van der Beeck}

\section{The 1656 context-the reversal of positive expectations of Hasanuddin}

The missive of February 1, 1656, contained nothing on policy deliberations Makassar. Nor do the two brief letters to the Directors dated 18 and 31 July, respectively.9 It may then seem reasonable to assume that up to late summer 1656 the feeling in Batavia was that the Company's relations with Makassar were well taken care of by the 1655 treaty. Still, Stapel points to the fact that friction and "lack of trust" in the Makassarese was beginning to show, ${ }^{10}$ and by the autumn of 1656 , there was open discord. The point of contention was that Makassarese sailings to Ambon had resumed and Hasanuddin claimed he was entitled to continue the sailings under the terms of the 1655 treaty. ${ }^{11}$ It seems reasonable to date the break with the 1655 model of trust and soft diplomatic approach towards Makassar with these events. The section on Makassar in the letter of December 4, 1656 is symptomatically dedicated to the deliberations on what steps needed to be taken regarding aggressive plans by Makassar.

\section{Textual an alysis, Makassar in the missive of December 4, 1656}

The focus on Makassar in the missive of December 1656 was on new problems with the sultanate, and how they could be blamed on Van der Beeck's poor

9 Symptomatically none of these are found worth mentioning in the relevant section in Stapel, Het Bongaais Verdrag, 52-55.

10 Ibid. 54 "weinig vertrouwen"

11 Ibid. 54-55. 
performance during the negotiations in December of the previous year. In short, the current problems were not the fault of the 1655 decision to negotiate as such, but were blamed on Van der Beeck's poor negotiating performance. He had accepted a treaty that "could give very little contentment" to the Company. ${ }^{12}$ The fault for the substandard treaty terms was given exclusively to Van der Beeck, who seemed to have understood "the High Government's instructions and intentions poorly" ${ }^{13}$ In fact, by acting in "direct contradiction to the High Government's intentions," ${ }^{14}$ Van der Beeck had concluded a treaty that was "totally adverse" to the Company's interests. ${ }^{15}$ Due sanctions had been taken, however: Van der Beeck was now excluded from the Council and had no prospects for promotion. ${ }^{16}$

\section{Comments}

Although ostracised because of his poor performance in 1655, Van der Beeck was still made commander of the return fleet in 1656. ${ }^{17}$ At an earlier time, he and his co-envoy Soliman had also been praised and rewarded for their "good services during the negotiations." ${ }^{18}$ After all, the 1655 treaty was no more than the logical result of Maetsuyker's trust in Hasanuddin. It therefore seems fair to propose that what had changed by December 1656 was not a loss of faith in Van der Beeck's ability as a negotiator but the belief in accommodation as means to solve the problems with Makassar. The merciless denunciation of Van der Beeck in the 1656 missive thus signalled that the High Government had made a decisive shift in expectations towards Makassar. What was the approach argued by the High Government, when confronted with new Makassarese intrusions in the Eastern Archipelago? In view of the challenging situation, a campaign against Makassar was out of the question: Batavia was quarrelling with Banten, it was at war with Aceh, Mataram kept its ports shut to the Company, and the kingdom of Johore and its allies were threatening Malacca. ${ }^{19}$ Appeasement to buy time was the selected option. At the end of

\footnotetext{
12 "Gans weynich contentement connen scheppen." December 4, 1656, GM 3.88.

13 "schijnende onse ordre ende mijninge daerinne qualijck te hebben begrepen." December 4, 1656, GM 3.88.

14 “directelijk met onse intentie strijdigh.” December 4, 1656, GM 3.88.

15 "Geheel ‘t onsen nadeele." December 4, 1656, GM 3.88.

16 December 4, 1656, GM 3.88.

17 DRB 1656, November 14, 10.

18 "De goede officien ... aen d'Ed. Comp." DRB 1656, Novermber 10, 8.

19 "doch uyt veele opsichten het contrarie seer soude mogen vresen." December 4, 1656, GM 3.88.
} 
1656 , the approach was thus to "keep up the appearance of peace towards the sultan but at the same time watch out for an attack." ${ }^{20}$ The tactics towards Makassar must be to offer the sultan every outward sign of peace, including engaging in negotiations that could possibly be drawn out for one to three years. ${ }^{21}$ That was a choice for "mock negotiations," negotiations that primarily served to bar the Makassarese from declaring war on the Company.

\section{Summing up positions and their implications in the missive of December 4, 1656}

A definite shift in Maetsuyker's assumptions and recommended policy towards Makassar is obvious in a comparison of the missive of December 1655 and that of one a year later. Although much of blame was given to Van der Beeck, the message of December 1656 was that the 1655 approach and treaty had proven totally unproductive. By implication, war was understood as the force that could bring about a viable interaction regime and treaty with Makassar. Because the present conditions ruled out that option, the tactics for the time being were to negotiate and to avoid war by buying time. Maetsuyker's positions on and understanding of "treaty" and "negotiations" in 1656 thus seem to have turned 180 degrees from the positions he had taken the previous year. That turn would find its full articulation in the missive of December 17, 1657.

\section{Section 3: The missive of December 17, 1657-full explication of an offensive policy towards Makassar}

\section{Context}

By December 1657, the Company's relations with Banten and Mataram had changed for the better compared to the previous year. Although the Bantenese had been provocatively aggressive in 1656 , the mood turned during 1657 , culminating with a Bantenese initiative for negotiations for peace in December. ${ }^{22}$ The tension regarding Mataram, too, had lessened somewhat, as the ports of

20 "Dien voorst (the Sultan of Makasar) vooreerst al wat te simuleren ende in te sien, maer sullen daeronder echter niet naerlaten naer vermogen op hoeden te sijn." December 4, 1656, GM 3.89.

21 "Soo den Maccassaeren haer maer voor een jaar á drie aen haere onderhandelinge trouwelijck houden gebonden." December 4, 1656, GM 3.88 .

22 Somers, Nederlandsch-Indië, 69. 
northern Java were reopened. As a feared pan- Islamist alliance against the Company did not materialise, the prospect of war with Banten, Mataram, and Makassar, which characterised the previous year, also subsided..$^{23}$ The Company was on the offensive in Aceh and entered negotiations in the summer of $1657,,^{24}$ but peace was not concluded until June 1659. In short, developments in 1657 presented a context that opened a wider range of options and a more offensive policy towards Makassar than the in previous year was possible.

\section{Makassar in the missive of December 17, 1657}

The policy advocated for Makassar in the missive of December 17, 1657, represents an explicit, final break with the approach of 1655 . Now the premise was that Hasanuddin would always look for an opportunity to increase his influence in the Spice Islands, no matter what he might promise to the contrary.

In December 1657, the High Government wrote that only a successful military campaign, devastating Makassarese power once and for all, could in the end secure a viable and lasting interaction regime with the sultanate. This in fact represented an endorsement of De Vlaming's long-held assumption that Hasanuddin and the Makassarese were by nature deceitful and could not be trusted in diplomatic dealings. With this newly adopted framework of principled distrust "negotiations" and "treaty making" came to be understood primarily in tactical terms.

\section{Textual analysis, missive of December 17, 1657: Validating Hasanuddin's hostile intentions and deceitfulness}

The High Government harboured no doubt that Hasanuddin was pressing his right to sail to Ambon in order to inspire a new rebellion there among the VOC's subjects. ${ }^{25}$ After the 1655 treaty had been signed, Hasanuddin had a copy of the contract taken to Ambon where it was shown to the pardoned rebels as a trophy. As the High Government saw it, Hasanuddin was posing as a

\footnotetext{
23 De Graaf, 1977, 106-107.

24 Stapel, Geschiedenis van Nederlandsch Indië, 358.

25 "buyten twijfel niet anders voor hebbende gehadt dan maer occasie te houden om U.Ed. onderdanen tegen U.Ed. daer weder op te ruyen.” December 17, 1657, GM 3.147.
} 
champion of the rebel's cause by perverting an act of mercy granted by the Company's generosity. ${ }^{26}$

Hasanuddin's spite in turning the Company's virtue into a vice and transforming his own vice into a virtue was but one incident where the High Government perceived a generally defiant arrogance and ill will towards the Company building up in Makassar. The Company's commissioners and residents were shown very little respect in public, and a demonstrative haughtiness by certain Makassarese nobles clearly indicated that Makassar was not inclined towards peaceful coexistence with the Company. ${ }^{27}$

\section{Comment: The emotional aspect of the turn from trust to distrust}

The High Government's main point in the drawing attention to the above incidents was clearly aimed at underlining the probability of plans for war in Makassar. The Company was facing a challenge of power politics. Still one should not underestimate the impact of Makassarese provocations to the Company's prestige. The issue of prestige had important implications for the Company's diplomacy, viewed both instrumentally in power politics, as well as taken as an insult to the Company by its own right. From a power politics perspective, not answering Makassarese provocations meant potentially undermining the Company's diplomatic capital in the archipelago at large as well as among potential allies in Sulawesi.

But there are strong indications that the High Government's grievances about the lack of respect may well have had purely emotional motives too. When Maetsuyker's and other advocates of accommodation held forth in 1657 that the sultan was acting with defiant arrogance against the Company, they must have done so with some feelings of having been deceived. After all, the Hasanuddin whom they in 1655 had presented as having learnt not to stick his nose into affairs that were none of his business was in 1657 presented as thumbing his nose at the Company. This may well help explain the

\footnotetext{
26 "Om daeruyt d'inwonders te doen blijcken van de liefde ende genegenheit, die sij (quasi) in het besluyten van hetselve met haerl. pardon van ons t' obtineren tot haerl. hebben bethoont om haer met hetselve op haer sijde te trekken." December 17, 1657, GM 3.148.

27 "is onsen commisaris ende residenten daer doorgaens seer cleen respect aengedaen, sulx sijl. Uyt verscheyde hoofden wel claerlijck doen blijcken haer aen U Ed. Vrundtschap gantsch niet en laten sijn gelegen." December 17, 1657, GM 3.153 .
} 
peculiarly "heated" tone in the deliberations on Makassar in the December 17 missive.

\section{Explaining the probability of Makassarese plans for war and conspiracy against the Company}

If not explaining the emotional aspect of its turnaround regarding what to expect from Makassar, the High Government did emphasise that Hasanuddin's provocations and the demonstrations of anti-Company sentiment in Makassar could only mean that the sultan and his nobles were once again planning for war. ${ }^{28}$ Furthermore, there was alarming evidence of the sultan and his court's encouraging the Portuguese to challenge the Company's military presence in Asia wherever possible. ${ }^{29}$ In other words, the prospects of war were not only considered very likely, they were considered very grave taking the MakassaresePortuguese conspiracy and alliance into account.

\section{The commercial conspiracy, already at work}

If the political-military conspiracy had not appeared in the open yet, at the commercial level a joint Makassarese-Portuguese conspiracy was already at work. By sailing under the Makassarese flag, Portuguese in Makassar were free to trade wherever they pleased ${ }^{30}$ and thus undermine the Company's monopoly rights in the Spice Islands. Judging from this practice and other "absurdities," ${ }^{11}$ there can be no doubt that the Makassarese were determined to continue sailing to the Spice Islands notwithstanding the terms of the 1655 treaty. ${ }^{32}$

\footnotetext{
28 "Soowel de Coningh en de grooten aengaet, alsoo lief met U Ed. weder tot oorloge traden, als in vrede bleven." December 17, 1657, GM 3.153.

29 "Daertoe haer buyten twijfel de Portguesen seer animeren om daerdoor alle uwe wapenen op de custe van Indien ende elders, waer se haer drucken, van hare halsen te crijgen." December 17, 1657, GM 3.153 .

30 "Trachtende haren handeel herwaerts ende derwaerts onder de naeme der Maccassaren ende haerl. ontsagh onbecommert uyt die platse te drijven." December 17, 1657, GM 3.153.

31 In this context to be read as "decoy-arrangments" i.e. on par with the Makassarese sailing flagging themselves as Portuguese.

32 "Al hetwelcke en meer en andere absurditeiten, de Comp.e bij dat hof aengedaen werdende, van ons sijnde ingesien ende dat sijl. onaengesien de vrede, die met haer gemaekt hebben, al echter niet sullen naerlaeten d'oosterse quartieren te bevaeren." December 17, 1657, GM 3.153.
} 


\section{The explanation of the post-1655 strategy}

It was time for the High Government to explain its new strategy. The shift in assumptions and the break with the 1655 line on accommodation began in a "soft voice," but soon rose in volume. The High Government had "seriously begun to have grave doubts about whether staying on friendly terms under the present conditions would serve the Company's interests and whether it would not be better served by once again going to war." ${ }^{33}$ The question must be read as a rhetorical one. The implicit request is illustrative of the post1655 conceptualisation of the position of war in the "war-negotiationstreaty triangle." As it stands in the missive of December 17, 1657, war was presented as the sole guarantor for a reasonable treaty with the Makassarese. In this regard, the High Government now assumed the same position De Vlaming had advocated in 1655. This begs the question: Why advocate for war in 1657 and not in 1656 ? The answer is simple: the context had changed. In 1657, Makassarese provocations had devolved from bad to worse and, just as important, the Company had gained control of the situation with Aceh and the danger of having to fight both Banten and Mataram had diminished.

\section{Arguing the case for war by referring to the deceitful nature of Hasanuddin and the Makassarese}

The High Government's argument for negotiations in 1655 had rested on the assumption that Hasanuddin could be trusted. The call for war in 1657 rested on the contrary assumption. Still, in the missive of December 17, 1657, there is a discrepancy between the uncompromising depiction of Hasanuddin' aggressive intentions, and the relatively "soft wording" of the proposition for militant actions. ${ }^{34}$ This may be explained by the fact that the Directors had been so eager for an end to the war in $1655 \cdot{ }^{35}$ On the one hand, there can be little doubt about the High Government's real intentions. It was no longer deliberating whether war would be the best way to secure a viable interaction regime with Makassar; that had already been decided. What the Councillors

"Soo beginnen wij grootelijckx te twijffelen of deselve vrede op dien voet de Comp.e al voordeelijck sal wesen, en of niet goet en sal sijn weder met haer in oorlogh te comen." December 17, 1657, GM 3.153. 
more likely wondered was the best way to sell this proposition to the Directors. It is against this background that we must read the remaining part of the letter, which contains a return to the "all reasons not to trust Hasanuddin" argument, and turns upside-down the cost-benefit arguments used to counter the pro-war argument in 1655 . In this section, the tone heats up again.

\section{The presentation of Hasanuddin as an unreliable partner in treaty making}

It is reasonable to think that, for the High Government, the Directors' acceptance of the war option rested on their conviction of the irredeemably deceitful nature of the Makassarese. The High Government worked hard to convince the Directors. Its first argument was that Hasanuddin's motives in signing the 1655 treaty had been purely tactical, and his agreement to a peace had only come about because at the time he was unable able to wage war effectively. ${ }^{36}$ But beneath a mask of friendliness, Hasanuddin still harboured plans to attack the Dutch. Given the consistently devious nature and aggressive plans of the Makassarese, an accommodating mode was thus not only futile but counterproductive: "Because the more we appease and accommodate them [the Makassarese], the more they claim [from us] and the more impertinent they become in their claims." 37 The real message read loud and clear: Hasanuddin must under no circumstance be regarded any longer as a reliable treaty-partner. Doing so would harm the Company's interests.

\section{Assurance of the commitment to fend off a Makassarese attack on Ambon and Banda}

On top of the harassment of continued Makassarese sailings to the Spice Islands, the High Government pointed to a range of incidents that clearly

\footnotetext{
36 "Niet anders namentlijck also deselve (tegen haer Haer Ed. Comp.e) met publicque oorloge niet hebben subsisteren." December 17, 1657, GM 3.148.

37

"hoe wij haerl. meer inwillingen ende caresseren, sij noch al meer ende van ons begeeren ende te stouter warden.” December 17, 1657, GM 3.148.
} 
indicated that Hasanuddin and his supporters were escalating their activities in the Eastern Archipelago. The Directors were however assured that measures had been taken to defend the Company's "precious" (costelijcke) possession of Banda and Ambon. Orders had been given that the defences on Ambon and Banda, belonging to the Company by right of conquest, be duly strengthened to ward off any intrusion by the Makassarese or anyone else. ${ }^{38}$

The reference to the Company's legitimate claims to defend its position in Ambon and on Banda "by right of conquest" is the only reference to international law in the deliberations on Makassar in the December 17 missive. The legality of a pre-emptive war on the other hand, were not considered. The option of war was, as in 1655 , discussed in terms of pragmatic cost-benefit considerations. If the mode of thinking in this regard was the same as in 1655, in 1657 both assumptions and conclusions of the war option had been turned upside down.

\section{A return to, and turnaround of, the 1655 cost-benefit arguments about war}

An important argument in the High Government's promotion of the war option in December 1657 was that the relatively low costs of war outweighed the gross long-term benefits to be gained from it. In essence, this was an endorsement of De Vlaming's position in 1655. Disregarding its argument of the lack of realism in the war plan in 1655, and countering the 1655 argument that war would mean a lessening of trade, and thus a loss of profit for the Company, in 1657 the High Government pointed out that war would disturb Makassar's trade. ${ }^{39}$ No mention was made of the Company's losses.

\section{Comment}

The arguments presented for war in 1657 illustrate not only the break with the positions of 1655 , but point to a break in the High Government's general mode of thinking about the VOC's relations with Makassar. In 1655, Maetsuyker's

38 "Soo hebben wij nu ordre gegeven, als voors. Plaetsen Comp.s eigen landen metten den swaarde gewonnen sijnde de voorsz. Vestinge daer hetsij met ofte tegen haerl. gemoede geweldelijck te doen leggen, ende de Maccasaren ende alle andere vremdelingen van daer en omtrent te houden." December $17,1657, G M 3.148$.

39 "Als wanneer wij haer in retorsie tenminsten oock haeren handel seer souden becommeren." December 17,1657, GM 3.153. 
assumption about Makassarese intentions in seeking peace rested on potential losses of trade due to war. The mode of argumentation in 1655 thus built on an assumption of shared concerns over trade losses as a motivation for peace in both Makassar and Batavia. In 1657, war and the impending losses in trade were the means to force Makassar to a lasting peace. By implication, the terms of the treaty to follow that war would be of a quite different nature than the treaty of 1655 .

\section{The argument concerning the excessive costs of war countered}

The High Government's positions in 1657 regarding the costs of war equalled De Vlaming's positions of 1655. The High Government now argued that the military expense of a campaign might well be kept within reasonable limits. A campaign would not imply much of an increase compared to what the Company was already spending on its defence of Ambon and Banda. In 1657 alone, the High Government had had to deploy 573 soldiers to discourage and prevent Makassarese intrusion..$^{40}$ That was approximately the same number that would be required for a campaign. War would thus mean minimal or no additional expense. ${ }^{41}$

\section{Reassuring that the security of Ambon and Banda is not jeopardised and arguing the soundness of the war plan}

The 1655 counter-argument to war had been that the transfer of troops from Ambon and Banda would jeopardise the defence there. This argument was rejected in 1657. Now the argument ran that the transfer of troops from Ambon and Banda was not only a necessary prerequisite for the success of the campaign, it should also be regarded as a tactically sound adjustment since the troops were already there, ready, and packed. ${ }^{42}$ Deploying them in Makassar was sensible and the High Government assured the Heeren XVII it would never do so in a way to cause peril. ${ }^{43}$ Timing was the decisive factor in the High

\footnotetext{
40 "Want wij desen jaere al echter om op haer ende haerl. bedrijf toe te sien een nombre van 573 soldaten sijn genootsaeckt geweest uyt te setten." December 17, 1657, GM 3.153.

41 "Dat al omtrent sooveel is wij by tijde van oorloge te doen plachten, ende dan weynich of gene oncosten mede gepraevenieert warden." December 17, 1657, GM 3.153.

42 "Indien wij deselve chrijghsmacht van daer over becomen." December 17, 1657, GM 3.153.

43 "gelijck vreesen, dat niet sullen doen mogen, soo wij geen pericul willen loopen." December 17, 1657, GM 3.153 .
} 
Government's argument here. If undertaking the campaign during the eastern monsoon, ${ }^{44}$ one need not worry about attacks on Ambon and Banda..$^{45}$ All in all, considering the serious challenge that Makassar posed for the Company, and the good prospects of a successful campaign undertaken at low cost and risk, it was the time to act. If no military actions were taken, the Company stood the danger of facing irreparable damage. ${ }^{46}$

\section{Inscribing Makassarese deceit towards the Company as structurally embedded}

Having advocated the arguments for going to war and the good prospects for success, the appeal to the Directors to endorse the plan returned to the basic premise, that the Makassarese could never be trusted. In its 1657 version, this view is given an additional twist. Deceit by the Makassarese towards the Company was described as a structurally inherent trait in Makassarese character and society. When the Makassarese had proven to be untrustworthy, it was because they were by nature opportunistic and would break contractual obligations at any time to serve their own best interests. ${ }^{47}$ Maetsuyker's volte-face could hardly be more striking. He now assumed that by their very nature they neither could, nor would, be trusted either at present or in the future.

\section{The cultural-religious argument}

The psychological argument for inherent Makassarese deviousness was supplemented by a cultural-religious argument. When the Makassarese by their nature would gladly break any promise with any party, the case for the Company was even worse, representing as it was a Christian party. ${ }^{48}$ The religious code in Islam read that it was no sin for a Muslim to dishonour a treaty with Christians, the latter being considered unbelievers. ${ }^{49}$ In short, regarding promises made to the

\footnotetext{
44 Meaning the period October-February.

45 December 17, 1657, GM 3.153.

46 “een onversettelijcke schade aengedaen te werden." December 17, 1657, GM 3.153.

47 "wie haer aen eeden trouwe ofte beloften niet houden gebonden, als sij met dezelve te breecken maer voordeelen te behaalen weten." December 17, 1657, GM 3.153.

48 "Doch vornaementlijck tegen ons Christenen te doen hebbende." December 17, 1657, GM 3.153.

49 "Die sij voor ongelovige houden en geen sonde van en maecken of sij bedriegen ende te cort doen ofte niet." December 17, 1657, GM 3.153.
} 
Company by the Makassarese, the latter could cheat and lie as much as they liked without breaking their own religious code. Makassarese fraud and deceit towards the Company were thus presented as structurally embedded, by both cultural predisposition and religious sanction. Any hope for change was naïve and futile.

\section{Comments}

Propositions that this negative portrayal of the Makassarese represents a typical Eurocentric perception would do well to consider the timing and context of these remarks. Rather than interpreting this characterisation as "orientalist," it would seem more to the point to regard it as ex post facto rationalisations of what was considered in Batavia as consistent Makassarese breaches of contract. One would also do well to view the proposition about inherent deceit in the light of the need to "sell" the war option to the Directors. After all, the High Government's advocacy for war basically rested on the proposition that words alone would never suffice and that a solid, durable treaty with Makassar had to be enforced by the sword.

In no way can the above remarks be regarded as originating from fixed Eurocentric preconceptions. The contrast between the declared optimism and trust that provided the arguments for the initiative for peace and the negotiations in 1655 and the realism that characterises the thinking in 1657 goes to disprove that. The thinking about the role of religion and the appeal to religious concerns may be said to have beencompletely reversed. The concessions made on religious grounds in the 1655 treaty sprang from an assumption of a separation between the religious and political spheres in Makassar. In 1657 the political implications constituted the primary focus. Learning from experience must explain this change of position from 1655 to 1657.

\section{Summing up the break with the 1655 assumptions and positions in the Generale Missiven of December 1656 and 1657}

The 1656 letter marks a general break with the optimism of 1655 and the belief that the differences with Makassar had been sorted out by the treaty that year. The 1657 missive to the Directors argued for a new direction. This shift must be explained by Hasanuddin's resumption of his activities in the Spice Islands, which was regarded as a clear breach of treaty in Batavia. But there was more to it than the terms of the treaty. The uncompromising pro-war stand, the 
language used, and the essentialist characterisations of Hasanuddin and the Makassarese in the 1657 missive betray the fact that the High Government felt fooled by Hasanuddin. It was a matter of restoring prestige and face.

In the deliberations over Makassar presented to the Directors after 1657, the issue was not whether to war, but whether the moment was ripe or not, or whether the desired result could be achieved in some other way. The missiven after 1657 and up to the war in 1660 reveal a fluctuation of recommendations for war and tactical considerations.

\section{Section 4: The missive of December 14, 1658 Context and focus}

The background for the approach to Makassar in the missive dated December 14,1658 , was that the Company was still formally in a state of war with Banten, but relations with Mataram had eased since the susuhunan (king) had reopened the northern harbours in the spring..$^{50}$ Still the fear of an anti-Company alliance between Mataram and Makassar lingered..$^{51}$ Letters and reports from Makassar and increased Makassarese activity in the eastern provinces confirmed and strengthened the Council's fears of Makassarese plans for war. ${ }^{52}$

The High Government's outward response to the Makassarese challenges of 1658 was accommodation, but it kept a sharp eye on the possibility of war. On August 20, merchants Joan Barra and Pieter Schuyftang were sent to Makassar to ease tension and keep relations as normal as possible. ${ }^{53}$ This was clearly a defensive move dictated by Batavia's ambivalent situation at the time. The missive of December 1658throws light on how Batavia viewed regional politics in the archipelago in an unclear situation, and how the High Government's presented its response to the Directors. Of special interest is that the prospect of being confronted by a coalition of Muslim states led to elaborate deliberations on the role of religion in overseas diplomacy, or more specifically, on how to tackle the religious divide between the Company and its Muslim friends and foes.

50 H.J. De Graaf, De Regering van Sunan Mangku-Rat I Tegal-Wangi, vorst van Mataram, 1646-1677, Verhandelingen KITLV, 33, S'-Gravenhage - Martinus Nijhoff, 1961, 107.

51 Ibid. 105.

52 Stapel, Het Bongaais Verdrag, 58.

53 Ibid. 58-59. 


\section{The fear of a Makassar-Mataram alliance, and the implications for the Spice Islands}

The section on relations with Makassar in the December 1658 letter started with a repetition of the 1657 position that the Company should not trust the Makassarese, but be on the alert. ${ }^{54}$ The High Government then turned to the the 1658 situation, namely that Makassar was trying to mobilise other powers in the archipelago as allies in its struggle against the Company. Information had been acquired that Makassar had sent envoys to Mataram asking the susuhunan to close the northern ports (of Java) to the Company. This initiative aroused anxiety that Mataram could be talked into trying to starve Batavia. ${ }^{55}$ The High Government believed that Hasanuddin presumed that a blockade of the northern harbours would lead to unrest in the Company's possessions in the eastern quarters. ${ }^{56}$ The contact between Makassar and Mataram thus confirmed and actualised the High Government's fear of aggressive Makassarese plans for the Spice Islands, "from which one most certainly should presume that the Makassarese had no friendly intentions towards the Company."57 That was a euphemism. The real message to the Directors read that in view of a possible MakassarMataram alliance, the Makassarese threat to the Company had acquired a new, more serious dimension, namely a threat to the Company's possessions in the Spice Islands.

\section{Deliberating on the nature of religion in Makassar's expansion efforts}

The mobilisation appeal behind the anti-Company alliance was taken to lie in the religious division between the Company and its Muslim antagonists. Makassar's religious prestige made possible a rallying of its co-religionists in

54 “Invogen wij voor dat rijcke altos wel verdacht ende op hoede sullen dien te sijn." December 14, 1658, GM 3.216.

55 "Havens voor ons weder soude sluyten om ons daermede tot necessiteyt ende hongersnoot te brengen." December 14, 1658, GM 3.216.

56 "Dat sij wel weten, dat in de oosterse quartiren strackx mede ongelegentheden verorsaeckt." December 14, 1658, GM 3.216.

57 "waeruyt men met recht wel soude presumeren, de voors. Maccassaren van geen goet voornemen tegen de Compagnie." December 14, 1658, GM 3.216. 
the archipelago against the Company. The fact that a significant Makassarese fleet had been sent to Mena on northern Timor to offer "protection" was but one example of how the political and religious dimensions were intertwined in Makassar's expansionism. The population on Mena was still heathen, but the Makassarese initiative could be regarded as part of a more encompassing plan by which the Makassarese sought to secure dominance over Mena by converting the population to Islam..$^{58}$

\section{Comment}

The worries over the Makassarese approach towards Mena serve well as a springboard to offer some comments on the High Government's thoughts on the role of religion and religious prestige in Makassar's expansion effort after 1655. As we saw in chapter 4, the concessions made in the 1655 treaty were made in large part in response to Hasanuddin's appeal to his concern for his co-religionists. Andaya takes this at face value, as an example of two contradictory means and ends constellations: Makassar was pursuing religious and political prestige by, among other things, economic means, while the Company sought power and prestige as means to increase its profit. ${ }^{59}$

My proposition regarding the Company's concessions is that these were given with the implicit understanding that Hasanuddin's motives had to do with religion and prestige only. Seen from the viewpoint of power politics, they were insubstantial. The Company's understanding at the time was congruent with Andaya's propositions. But in 1658, the explicit understanding was that the appeal to religion went hand in hand with, or was even deliberately used for, political purposes. When the High Government that year pointed out that the Makassarese court was well known for its religious $\mathrm{zeal}_{,}{ }^{60}$ the issue of concern was clearly the ability to mobilise political and -military support that Makassar possessed by means of its religious prestige. The scenario depicted in 1658 was that the Company faced the prospect of war with the three largest Muslim powers in the archipelago, Mataram,

58 "Sij haere dominie over die eylanden noch mede sullen soecken te verbreyden ende desselve, noch heydenen sijnde, tot de Mahumetise religie te brengen." December 14, 1658, GM 3.216.

59 Andaya, The Heritage of Arung Palakka, 46.

60 "In hetwelck het Maccassars hoff op haere wijse vrij devoot schijnt te sijn." December 14, 1658, GM 3.216. 
Banten, and Makassar. Joined together in faith and purpose, these would represent a formidable power, both ideologically and militarily. However, in the 1658 text, the magnitude of the challenge of the combined forces united by faith is not further elaborated. This could be explained by the fact that the implication was more than clear enough at the outset. For my purposes, the relevant point is that the High Government was aware of both the twin religious and political nature of Makassarese expansion and the potential of using religion as a tool for political mobilisation in the archipelago, and that this represented a shift compared to the thinking in 1655 .

\section{The High Government's change of view on the mix and hierarchy among the pursuits of power, prestige, and profit}

Andaya's cultural-divergence model shows an absolute dichotomy between the Company's quest for influence in the Eastern Archipelago and that of the Makassarese: Makassar sought pride and prestige, the Company optimal trading opportunities. As I have pointed out in the analysis of the 1657 missive above, as well as in my analysis of the instructions from the Netherlands, there are reasons to believe that the preservation or restoration of prestige, both at the individual, personal level and for the Company as a corporate unit a role in political considerations both at home and in Batavia. The frequent display of corporate pride in rituals and ceremonies when celebrating Company successes at Batavia is a phenomenon that comes to mind. ${ }^{61}$

A comparable, if not necessarily identical sense of "prestige" and "pride," whatever its cultural particularities, likely played a part in both Batavian and Makassarese politics. If the Company's politics were not free from "contamination" by non-commercial concerns, it seems unlikely that Hasanuddin's politics were absolutely "uncontaminated" by secular concerns of profit and power. Such differences as there were between the Company and Makassar seem more appropriately explained as a divergence in "mix" and balances than by absolute dichotomies.

The proposition of the December 1658 missive is that Hasanuddin played his religious-prestige card in a game he also conceived of in terms of power

61 See F. De Haan, Oud Batavia, 2nd ed. (Bandoeng: A.C. Nix, 1935), 135 ff. 
politics. The High Government no longer viewed the assumptions about religious concerns as purely symbolic. In 1658, Batavia acknowledged the substantive role of religion in the power politics of the Indonesian archipelago.

\section{Concluding the analysis of the December 14, 1658 letter: The difference of tone in the 1657 and 1658 letters}

A striking feature of the 1658 missive is that it is calm and "matter of fact" in tone compared to the one of December 1657. My suggestion is that the "heated" tone of the earlier letter reflected the then still-fresh feeling of having been cheated by Hasanuddin. By 1658 , the assumption of Hasanuddin as a fraudulent partner in diplomacy had become a premise in the High Government's thinking about Makassar. After the initial "emotional blow-out" in 1657, the High Government went back to a cooler presentation on how to handle Makassar based on their new set of assumptions.

\section{Shared characteristics of the 1656, 1657, and 1658 missiven in contrast to that of 1655}

What distinguishes the approach to Makassar in the three missiven of 1656 , 1657 , and 1658 is that they originate from a perceptual framework markedly different from the one of 1655 . Those of 1656 and 1657 made clear that the High Government's preferred solution to the problems with Makassar was a military campaign. In the 1658 , that station was already passed. Starting a war on Makassar was out of the question because it might help trigger a war with a broader anti-Company alliance. The Company reverted to a time out for tactical reasons. When in August 1658 Barra and Schuyftang were sent to obtain the sultan's permission to reopen the Company's trade in Makassar, their instructions were to concede to all Makassarese claims "as much as the Company's prestige could suffer." 62 This does not mean that the idea of going to war against Makassar had been abandoned. In the 1658 setting, negotiations and accommodation were forced by the logic of the political situation at large.

62 "als behoudens Compagnies reputatie eenigzins mogelijk was." Instructions to Barra, August 20, 1657, in Stapel, Het Bongaais Verdrag, 58n5, taken from Van Dijk, "Borneo." 
The purpose of Barra's and Schuyftang's mission was to temporarily cool down the situation.

\section{Section 5: The December 16, 1659 missive: Reporting on Negotiations with Low Expectations The primacy of contextual considerations}

Three events mark the period January-December 1659: the sending of another embassy to Makassar, headed by Willem Basting, who left Batavia on February 25; the outbreak of rebellions against Makassar by Mandars and Bugis; ${ }^{63}$ and the long-delayed decision to wage war on Makassar in the coming November. ${ }^{64}$ Of these events, only the Basting mission is elaborated on in the December 16, 1659 missive. The decision for war was not included, but the Mandar and Bugis rebellion was mentioned as a factor that was diverting the energy of Makassar court away from the Spice Islands.

The High Government did not refer to the possibility of creating an alliance with the Mandars and Bugis however. (Those issues would receive full attention and elaboration in the missive of December 16, 1660.) But, the section on Makassar in the December 1659 letter was dedicated to the Basting mission. This is surprising, considering that the 1659 context presented a scenario in which the option of putting De Vlaming's original plan of intervention was much more relevant than in 1658. Contributing to this was that peace had been concluded with Banten in July 1659. ${ }^{65}$ My proposition is that this new situation made the High Government ambivalent about the Basting negotiations. In my analysis of the missive of December 16, 1659, I shall focus on how this ambivalence towards negotiations colours the High Government's presentation of it to the Directors.

\section{The chronology of the Basting mission}

On January 10, the High Government sent lengthy instructions to Barra and Schuyftang in Makassar, informing them of its plans to send out a negotiation

\footnotetext{
63 Andaya, The Heritage of Arung Palakka, 48.

64 Stapel, Het Bongaais Verdrag, 62.

65 See Corpus Diplomaticum, 2.155-61.
} 
mission to "seek out" the possibilities for an agreement with Makassar, even though there was little hope of success. On February 10, the Council decided to send Willem Basting on this mission. He was instructed to be accommodating with respect to Makassarese damage claims, but he was to stay firm on the demand that the Makassarese must keep out of the Spice Islands. ${ }^{66}$ Inconclusive negotiation between Basting and Hasanuddin took place in Makassar on April 1,7 , and $27 .{ }^{67}$

The chronology of the negotiations suggests that the main purpose of this embassy might well have been to buy time. In response to Hasanuddin's claims of his contractual right to sail to the Spice Islands, Basting insisted that he had to confer with his superiors in Ambon before taking a decision. For his part, the governor of Ambon, Jacob Hustard, declared himself unauthorised to take a decision on the matter. Basting's mission in Makassar ended inconclusively when he asked the sultan for permission to return to Batavia to discuss the matter and get a decision from the highest authority directly. On his return to Batavia on September 16, Basting gave his oral report. The crux of the problem remained the sultan's insistence on his lawful right to sail to and from the eastern quarters.

\section{Textual analysis}

The essence of the High Government's presentation of the 1659 negotiations to the Directors was that it had stuck to an outwardly accommodating approach. During the negotiations, it had, for instance, let go of its initial claim that Hasanuddin swear by oath that once his damage claims had been met, he would have no further claims on the Company. ${ }^{68}$ In the fall of 1659, the contextual counter-arguments against war in 1658 had changed. A treaty of peace and friendship had been concluded with Banten on July 10, 1659. ${ }^{69}$ Moreover, the Mataram-Makassar alliance had failed to materialise and relations between the two were cool until November the same year. ${ }^{70}$ As the High Government saw it, the probability of Hasanuddin going to

\footnotetext{
66 Stapel, Het Bongaais Verdrag, 59.

67 For this and the below on Basting'as mission, see ibid. 60-62.

68 December 16, 1659, GM 3.253.

69 Corpus diplomaticum, 2. 155-160.

70 De Graaf, 1961, 49-50.
} 
war alone was low. On his own, without foreign help, he was no match for the Company. ${ }^{71}$

The decision for new negotiations in the beginning of 1659 must be seen against the background of general pressure from home to avoid war, and because the peace with Banten had not yet been concluded.

Considering the change of context in the autumn of 1659 , it is a puzzle that a more offensive approach was not considered. The High Government's presentation of Basting's report quickly kills any propositions about a possible return to the accommodation model. The High Government felt provoked by what it deemed as Hasanuddin's contemptuous treatment of Basting. However much the High Government regarded its own proposals and claims to be "totally fair and reasonable," ${ }^{72}$ Hasanuddin had been presenting his own desire in a "most disrespectful manner." ${ }^{33}$ This, the High Government held, must lead to the conclusion that Hasanuddin was only looking for a pretext to declare war to have his way with the Company completely on his own terms, rather than seeking a peaceful agreement in earnest. ${ }^{74}$ The Makassarese performance had only confirmed the High Government's pessimistic assumptions about Hasanuddin.

The report to the Directors on the negotiations in the December 1659 missive suggests that war as the ultimate means to finally resolve all the problems with Makassar was still in Batavia's mind. If negotiations and compromise were forced upon the Company from an excess of caution and the still unclear situation in 1659, the conditions were drastically changed in the following year. The December 1660 missive portrays expectations of military intervention as the ultimate problem-solver.

\section{Section 6: The December 16, 1660 missive}

The missive of December 16, 1660 encapsulated the period in which a new war with Makassar was launched and a new treaty was agreed on. It also covered a

\footnotetext{
71 "sij allenigh sonder uytenlandts behulp tegen de Comp.e niet substisteren connen." December 16, 1659, GM 3.252.

72 “niet dan volcomen redelijk ende billicke sijn.” December 16, 1659, GM 3.252.

73 "Hebbende haer begeeren oock op een seer laetdunckende wijse den commisaris bekentgemaeckt." December 16, 1659, GM 3.253.

74 "Waeruyt men eerder soude mogen geloven, sij maer redenen soecken om met ons weder tot oorlogh te comen ofte ons t'eenmemael naer haere pijpen dansen, dan dat se van ons trachten voldaan te wesen." December 16, 1659, GM 3.253.
} 
dramatic shift in context as a new Bugis rebellion against Makassar broke out in spring $1660 .{ }^{75}$ This took place after an armistice had been signed between the Company and Makassar, but before the final treaty had been countersigned. The High Government's presentation of relations with Makassar reflects this shift in opportunity. Now the grand strategy was conceived of as the only means that could establish a lasting solution to the problems with Makassar. But, when this option fell with the suppression of the Bugis rebellion, the High Government fell back on a return to the negotiated treaty. I shall analyse these shifts, and will be arguing that Batavia reverted to the latter option out of necessity. The lure of the ultimate solution promised by the grand strategy was still there.

\section{Brief diplomatic chronology, January-December $1660^{76}$}

In January and February 1660, a war fleet under the command of Major Johan van Dam and chief merchant Johan Truytman sailed for Makassar via Ambon. On June 7 , they arrived at the Makassar roadstead where they engaged in a sea fight with the Portuguese. The Makassarese responded by hoisting the war flag. On June 12, Company forces succeeded in taking the strategically important Fort Panakkukang, south of Makassar city. With the fall of the fort, the Makassarese asked for an armistice, which was agreed to the next day. Two important conditions were set for an armistice, namely that the Makassarese send envoys to Batavia to sign a new treaty, and that the Company evacuate the fort until a final peace had been signed.

Van Dam returned in Batavia on July 17 with the Makassarese envoys, and negotiations started in Batavia on July 29. On August 19, a new treaty between the Company and Makassar was signed in Batavia. ZachariasWagenaar and Jacob Cau were assigned to bring the Makassarese envoys home and obtain the sultan's countersignature. They arrived in Makassar October 13, but were not given access to Hasanuddin until November, when they found themselves in a different kind of negotiation situation than they had expected. Hasanuddin proposed radical

76 The below based on Stapel, Het Bongaais Verdrag, 61-68, who in his turn draws heavily on Van Dam Van Ijselt, Mr. Johan van Dam en sijne tuchting van Makassar in 1660, Bijdragen, KITLV, series 7, part 6 (1908): $16 \mathrm{ff}$. 
revisions of the Batavia text and raised new claims. Nonetheless, on December 3, Hasanuddin countersigned a revised version of the August 19 treaty in Makassar.

\section{The Bugis rebellion, 1660}

Hasanuddin was aware of the possibility that the Company might seek an alliance with rebellious Bugis. ${ }^{77}$ Already in February, he had started consolidating Bugis commitment to the defence of the realm, calling in troops from his vassal states as well. In June 1660, he called in manpower to build fortifications for the defence of the capital. ${ }^{78}$ The beginning of the Bugis rebellion can be dated to August 7, when the Bugis in Makassar, some ten thousand of them, decided to return to their homeland because of excessive burdens laid on them in conjunction with the war. ${ }^{79}$ Once returned, they reorganised themselves to rebel against Makassarese overlordship. Hasanuddin on his side raised forces to bring them back into the fold, but it was not until the beginning of October that the rebellion was quelled. ${ }^{80}$ It is worth noting that the Makassarese envoys to Batavia sailed at the beginning of the Bugis rebellion and before serious fighting had broken out. The beginning of the negotiations for the Countersignature in Makassar started before the outcome of the rebellion was clear, whereas the actual countersignature of the treaty took place when the rebellion had been quelled.

\section{Topics and issues in the missive December 16, 1660}

Stapel comments on a divergence in the historiography regarding the High Government's instructions to Van Dam. ${ }^{81}$ Valentijn has it that Van Dam was instructed to negotiate before engaging in actions of war. Stapel however, subscribes to Van Ijselt's version, ${ }^{82}$ which holds that Van Dam was instructed to immediately open attack after having rescued the three remaining Company servants still residing in Makassar. ${ }^{83}$ There is all the reason to support the latter's view. Searching for the possibility of a negotiated solution before acting

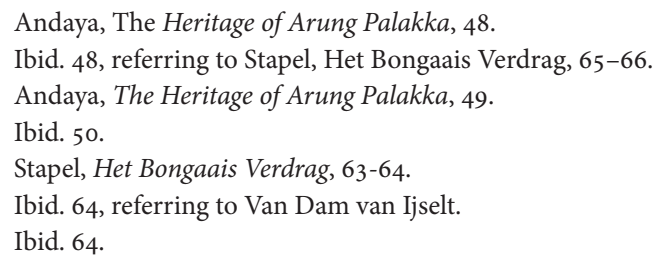


was what one would have expected according to standard procedure. ${ }^{84}$ But because Hasanuddin still stood by his claims in the Eastern Archipelago, the standard procedure no longer applied. The General letter of December 16, 1660, bears witness to that. The High Government's basic preoccupation now was how to cripple Makassar both politically and militarily so that it would no longer pose a threat to the Company. In the period between the sending off of the Makassarese for the signature of a treaty in Batavia and their return for countersignature in Makassar, the Bugis rebellion had made it seem that De Vlaming's plan could be executed, but after the defeat of the Bugis, conditions returned to "normal."

\section{The contextual imprint in the December 16, 1660 missive on Makassar-and the slide from realism towards cynicism}

If the tactical options of the Bugis and Mandar rebellion in 1659 were not yet commented upon in the missive of December that year, in the following year they were dealt with in full. The topic in this section is how the High Government presented this situation in the Missive of December 1660.

With the Bugis uprising in August 1660 and its final repression by the Makassarese in early October, the missive of December 1660 covered a period of two diametrically opposite contexts as far as Batavia's strategic options towards Makassar were concerned. The Bugis-rebellion revived plans for allying with the rebels to solve the problem of Makassar by intervening militarily on the side of the Bugis. The "grand strategy" fiercely rejected by Maetsuyker and the Council in 1655 now popped up again, expanded to involve a total restructuring of the political landscape of South Sulawesi. But in October, when it was clear that the Bugis stood to lose, there was a reversion back to the negotiation approach. This was a totally pragmatic shift. The advocacy for negotiation was mixed with speculation about the inevitability of a new war in which the opportunity to implement the grand strategy might well present itself again. The change in meaning of "negotiations" in the 1660 policy recommendations may be characterised as an explication of a glide from a realistic to an outright cynical understanding of it.

84 Compare for instance the procedure in 1654 , See chapter 5. 


\section{Textual analyses, the December 16, 1660 missive on Makassar: Defending the decision to go to war}

The section on Makassar in the December 16, 1660 missive starts, not unexpectedly, with a ritual assurance that the Company's possessions in Ambon and Banda were now both duly protected and secured against Makassarese intrusion. ${ }^{85}$ The High Government immediately went on to defend its decision to go to war against Makassar. This should have given ample opportunity to legitimate it in terms of international law.

It was an opportunity neglected. The defence of the decision for war was accorded one paragraph only, and the argument for it was exclusively contextual: At the time of the decision it was considered that either Batavia or Makassar would start a war; and it was deemed that it had better be the Company as "the time seemed right. ${ }^{86}$ The "right time" in this context is best translated as "availing oneself of the window of opportunity." The viability of the option was judged by opportunity, not by law. In other words, the High Government's rationale for going to war reflected nothing more than raison d'état thinking brought overseas, pure and simple. That this was the dominant mode of thinking is further illustrated by the High Government's explanation of favourable conditions for successful intervention.

\section{Advocating the grand strategy}

With the outbreak of the Bugis rebellion in August, a Company alliance with them and others chafing under Makassarese authority, of which there were plenty, to overthrow the present regime was presented as highly realistic. ${ }^{87}$ The prospect of toppling Hasanuddin's regime by joining forces with local rebels was even more alluring because it opened a window of opportunity for dealing a crippling blow to Makassar's politico-military power. It would reorganise the political structure of South Sulawesi in such a way as

\footnotetext{
85 "De waardevolle provincie Amboina is royaal van alles voorzien, zo van 700 soldaten w.o. voor Banda, en dat wegens Makassar, waartegens overal dient gewaakt." Dececember 16, 1660, GM 3.314.

86 "hebben dan geraden geacht beeter te sijn, wij selfst eerst op waren ende trachten...Indien het de tijt noch veelen conde, haer in haer eygen landtbodem te vallen." December 16, 1660, GM 3.318.

87 "Op hoope soodanig dese ende gene gemisconteerden (wie daer veele sijn) mochten gaende werden om de wapenen beneffens ons tegen de presente monerchale regeringe mede op te nemen." December $16,1660, G M 3 \cdot 318$.
} 
to dethrone Makassar as a hegemon and reduce it to only one among many powers on the island: "Makassar's might and power could be broken or kept in check for the foreseeable future by dividing the realm into smaller entities, such as had been the case before the Makassarese expansion ${ }^{88}$. This was how the Company's "promised land" of political order in South Sulawesi was envisioned: divide et impera. It was also an unofficial endorsement of De Vlaming's plan of 1655 .

\section{Comment}

Despite its hardly concealed optimism for a final resolution of the "Makassar problem," the call for implementing the "grand strategy" was remarkably calm considering the dramatic measures it proposed. Not only a direct military intervention, but a role for the Company in the construction of a new political order was implied. But with the Makassarese defeat of the Bugis in October, the scheme was put aside for the time being.

\section{Policy preferences fluctuating as to information about context}

Van Dam returned to Batavia with the Makassarese negotiators on July $17,{ }^{89}$ and the Bugis rebellion did not break out until August, so at the time of concluding the negotiations in Batavia, the High Government either did not know of it, or, if it did, felt bound to go through with the process of negotiations now that they had started. Reflections on the option of implementing the more tempting grand strategy must have taken place sometime between the conclusion of the treaty in Batavia on August 19 and the sending of the WagenaarCau mission for countersignature in Makassar on October 13. On the other hand, there is evidence that Cau contacted the Bugis to seek out the possibility of an alliance as late as in November. ${ }^{90}$ It is improbable that Cau would have undertaken this without prior consent or instructions from the High

88 "Mitsgaders deselve trachten te destrueren ende het gemelte rijck weder onder verscheyde cleyne souvereyne Coningjens verdelt te helpen Sooals hetselve voor desen geweest is. December 16, 166o, GM $3 \cdot 318$.

89 Stapel, Het Bongaais Verdrag, 66.

90 Ibid. 67. 
Government. When the Bugis were finally defeated, however, the only realistic option left was to go through with the treaty agreed upon with Hasanuddin.

\section{Comment}

What is striking about the 1660 negotiations for counter-signature of the treaty signed in Batavia on August 19 is that it represented a "double play" in the sense that Batavia was negotiating for a treaty while at the same time searching for possibilities to overthrow its treaty partner. This might be indicative of the fact that negotiations had been "devaluated" to purely tactical devices to be reverted to as long as the grand strategy could not be carried out. Moreover, the Company in the first place had signed a treaty, which meant it had to be honoured. Then again, that was as far as the legal considerations went. More important is that if the High Government seems to have been ambivalent about whether to proceed with the treaty or search for opportunities for an alliance with the Bugis rebels in the late autumn, this should be regarded as a turn towards a cynical interpretation of the diplomatic interaction with Makassar. That turn was not at all legally dogmatic, simply contextually pragmatic.

In the final paragraph of the section on Makassar in the December 1660 missive, the subtext clearly reveals that the High Government at the end of the day placed its bet on another war with Makassar. The section ends by stating that the Makassarese had regained their spirit and started to rebuild their military strength, ${ }^{91}$ but that under the circumstances, there was not much the High Government could do about it." ${ }^{2}$ This reads like regret for a lost opportunity, but it also reads as an implicit hope that such an opportunity would present itself again soon, even if that meant bending the terms of the newly signed treaty.

\section{Bending treaty agreements on Fort Panakkukang in the hope of implementing the grand strategy}

One of the terms of the August 19 treaty in Batavia was that the Company could hold on to Fort Panakkukang until the treaty had been countersigned in

\footnotetext{
91 December 16, 1660, GM 3.318.

92 "Sulcx het schijnt, offer bij dusdanige gelegenheyt door ons niet veel op te doen soude sijn." December 16, 1660, GM 3.319.
} 
Makassar. ${ }^{93}$ With a view to the prospect of another local uprising against Makassar, this ruling was bent to give room for a devious plan. By holding on to the fort the longest possible, the High Government reasoned that the Company might well be able to inspire a new rebellion. Holding on to the fort was thus of strategic importance if an opportunity for intervention in an internal conflict should arise in future. Also, the longer the Dutch held the fort, the more Makassar would lose respect, already on the wane, from its subject people. ${ }^{94}$ The implication was clear enough: loss of respect meant a higher probability for another revolt. It was explained in the following manner: no one could know what the "hot-headed" Bugis would do if the Makassarese tried to regain the fort and were unsuccessful. 95 In short, what the High Government proposed was to bend the terms of the treaty to recreate favourable conditions for the implementation of the grand strategy. However much it may have paid heed to international law, whatever the Company's insistence on pacta sunt servanda, the High Government's perception of treaty making with Makassar in 1660 must be characterised as cynical power politics applied to local, overseas conditions, rather than an uncritical import of European legal formalism.

\section{Comments}

In my view, the position of the High Government towards Makassar as presented to the Directors in the missive of December 16, 1660, represents what can be regarded as the culmination of a downward spiral into cynicism after the breakdown of the order created by the 1655 treaty. Military victory increasingly came to be regarded a far more attractive means of solving the Company's otherwise intractable problems with Makassar, and it was only the lack of favourable local conditions that spoke against it. Such conditions arose briefly in 1660, but entanglements barred Batavia from taking full advantage of the resulting opportunity.

The temptation to make use of the Bugis rebellion as the springboard for launching the grand strategy in 1660 must understood as preconditioned in a

\footnotetext{
93 August 19, 1660, treaty, art. 25, Corpus Diplomaticum 2.176.

94 "Conde het wel sijn, wij reputatieushalve de voorsz. Vestinge noch voor een wijle tijt bleven in behouden ... De vrees van de omliggende volken voor dat rijck (Makassar) is gedaald.” December 16, 1660, GM 3.319.

95 "Wat veranderingh hetselve in de keeteloorige Boegesen soude veroorsacken mogen." December 16, 1660, GM 3.319.
} 
decreasing trust in Hasanuddin as a reliable partner after 1655. The loss of trust hardened the belief in the war option as the favoured means of bringing him to heel. With that came a more cynical view of "negotiations" and "contracts" as second-best options.

\section{Section 7: The Missiven of January 26 and December 22, 1661: The grand strategy in a novel design}

One of the clauses of the 1660 treaty stated that the Portuguese had to leave Makassar within a year. ${ }^{96}$ The English stayed put, however, and filled much the same function that the Portuguese had done. How to solve this problem? "We lean towards the opinion," stated the High Government to the Directors in the missive of January 26, 1661, that "as long as we can't keep the English from sailing to enemy places, we will be better off continuing the war with Makassar than making peace."97 Following the conclusion of the 1660 treaty, the High Government came to take an ambiguous attitude towards the grand strategy as the ultimate solution to the conflict with Makassar, based on pragmatic considerations. On the one hand the Company's strengthened commercial position, and especially the expulsion of the Portuguese, gave way to a kind of thinking that the expulsion clause would suffice as the basis for entrenching the Company's power and influence in Makassar. At the same time, remnants of the original grand strategy survived in the form whereby the Company's new commercial position could serve as a basis for Company dominance over Makassar. This ambiguity is demonstrated in the missive of December 22, 1661.

\section{The plans for the post-1660 commercial regime and its political implications}

The missive of December 22, 1661 may be read as a temporary return to the accommodationist line. It stated that the High Government would "as far as

\footnotetext{
96 December 2, 1660, treaty, unnumbered clause 7, Corpus Diplomaticum, 2.178.

97 "van gevoelen sijn dat als ' $t$ niet en ware om de Engelsen, en dat wij deselve niet mogen verhinderen op vijantlijcke plaetsen te varen, het voor de Comp.e al soo dienstich soude wesen met Mqacassar in oorlogh te continueren dan vrede te maecken." January 26, 1661, GM 3.367.
} 
possible take care not to provoke, but rather please the sultan." ${ }^{98}$ In particular, one had to relieve him of any notion that the expulsion of the Portuguese would lead to commercial strangulation of Makassar. ${ }^{99}$ The latter point explained the choice of accommodation. It must be seen as a tactical device to make Hasanuddin comply with the expulsion clause of the 1660 treaty.

But the High Government also presented the exclusion of the Portuguese as the first step of a broader plan to gain a commercial monopoly in Makassar. The catch was that to succeed the High Government had to play its cards shrewdly. To make commercial dependence on the Company more palatable, assurances had to be made to the sultan that the Company would provide even more cloth and other items than had hitherto been brought to Makassar by the Portuguese. ${ }^{100}$ The High Government also had to guarantee that there would still be room for local Makassarese commercial interests. ${ }^{101}$

\section{Comments}

These concessions were made so as not to suffocate the local economy of Makassar and were directly linked to the plan of replacing the Portuguese in foreign trade by the Company. The plans for the Company's enhanced commercial position in Makassar can thus be seen as a part of the grand strategy of political domination by economic means. The High Government only implicitly revealed the political aspect of its commercial grand strategy. But when it stated that by occupying the role of chief provider of Makassar's imports, it was clear that the Company would in due course drive out both the English and the local Moorish traders. ${ }^{102}$ By depriving Makassar of commercial partners and tying the sultanate commercially to the Company, the Company was also isolating Makassar from potential allies against the Company.

\footnotetext{
98 "Maer om sijn gem. Hooghheyt sooveel doenel. tegenmoet te comen." December 22, 1661, GM 3.376.

99 "De apprehensie, die hij van Macassars ondergangck sij hebbende te doen verdwijnen." December 22, 1661, GM 3.376.

100 "Het lant van Macassar nu wat meerder van alle hande lijwaten ende andere getrockene waren te voorsien als voor desen." December 22, 1661, GM 3.376.

101 "ende daermede wat neering in de stadt te maken." December 22, 1661, GM 3.376.

102 "ende sal hetselve meteene dienen om de Engelsen en de Mooren mettertijt mede te doen verhuysen." December 22, 1661, GM 3.376.
} 
The accommodation advocated was no more than a tactical device to make the plan work. It simply required some co-operation from the sultan, and his co-operation in its turn required obtaining his goodwill. One of the proposed means of easing his worries was, as we saw above, to convince him of the advantages of co-operating commercially with the Company. Another was to obtain his goodwill by buying him off. To give a better "grip" on the Company's takeover of Makassar's foreign trade the High Government thus decided to give the sultan a substantial gift, to the value of around 20000 guilders, in order to "soothe his losses" and "ease his bitterness." ${ }^{103}$

\section{Summing up}

The December 1661 tactics towards Makassar reflected adaptations to the context after the Bugis rebellion had been quelled. Prospects for a war in combination with an internal uprising had waned, and the High Government had to work with what they had obtained in the 1660 treaty. Of primary importance in the treaty was that it guaranteed-in writing, anyway-that the Portuguese would leave Makassar. That opened the opportunity for the Company to drive all unwanted third parties out. To make that happen, the Company had to act with courtesy and accommodation towards the sultan.

In essence the High Government's strategy as spelled out in the missive of December 22, 1661 was that a commercial monopoly would do double duty by securing both the Company's commercial and its political position in Makassar. In that strategy, war was redundant. A dominant position for the Company over Makassar would be secured by the sultanate's commercial dependence on the Company. In this sense, the 1661 plan represented an alternative to the grand strategy based on military intervention. At the same time, it implicitly represented a plan that would place Makassar in category 2 of the 1650 instruction, if the other European nations were expelled too. In this latter aspect, the commercial takeover plan was but a variant of the original grand strategy by contractual commercial means.

103 "ende om hetselve noch wat meer klem te geven soo is oock verstaen Sijn gem. Hoockheyt dit eerste iaer tot versoetinge van sijn schade ende om het ongenoegen weg te nemen, toe te senden een aensienel. Schekagie, begroot 20000 gl. of daeromtrent." December 22, 1661, GM 3.376. 


\section{Chapter Conclusion}

I have included the High Government's plan of 1661 of establishing a viable interaction regime by commercial dependence because it succinctly illustrates the range of tactical options deliberated and advocated by the High Government in the period after the signing of the 1655 treaty and in the immediate aftermath of the signing of the 1660 treaty. When there were fluctuations in perspectives on particular points of policy, these can generally be accounted for by changes in appreciation of the contextual constrictions and opportunities encompassing the wider world of insular Southeast Asia. Flexibility by considerations of context, in other words, was the basic principle in the High Government's policy planning. Principles of law mattered less, if at all. The former went with a pragmatic approach, the latter with a dogmatic one. In general, pragmatism reigned supreme. 



\section{7}

\section{Learning to contract, 1:}

From contractual regulations of interaction towards construction of a relational regime $1637-1660$

\section{Section 1: Chapter introduction}

\section{Topic}

The topic of this chapter is the nature and dynamics of the High Government's treaty making with Makassar between 1637 and 1660. The relevant contracts include in addition to those of 1637 and 1655, already analysed, also the one agreed on in Batavia August 1660. The ones concluded in Makassar in November 1667 and the March 1668 treaty with Tello will be treated in the subsequent chapter. Of the three treaties treated in this chapter, the one of August 1660 will be given priority. The 1637 and 1655 contracts will primarily be referred to for comparative purposes.

\section{Propositions}

According to Andaya, the 1655 treaty marks a deviation from the norm of Eurocentrism in the Company's treaty making with Makassar. ${ }^{1}$ The other contracts, and especially that of November 1667, except for certain

1 Andaya, "Treaty Conceptions and Misconceptions," 287. 
superficial local imprints, still conform to a Eurocentric norm that was incomprehensible to the locals. ${ }^{2}$ I have already discussed and rejected Andaya's proposition about absolute incomprehension. In this and the following chapter, I shall reject Andaya's proposition about the Eurocentric nature of the Company's contractual record with Makassar. I shall instead argue that, in both form and content, the contracts from 1637 to 1668 were primarily marked by assumptions and considerations about local conditions. All these contracts were designed to meet the Company's needs as local conditions and the situation regarding relations with Makassar were perceived at the time. That is my general proposition about the overseas nature of these contracts. Second, I shall also be arguing that Andaya's notion of the inertia of the Company's approach towards treaty making, or to be more precise, its fixity to the European model of treaty is simply misleading. There was a dynamic, and the direction of that dynamic was towards increasing adaptation of the treaty to the local context and situation. This was not an even process however.

\section{Continuities and breaks in the dynamics of treaty making}

If we seek to establish phases in the Company's needs and perceptions, the period following the 1655 treaty could regarded as marking a break between two distinct phases. Up to and including the 1655 treaty, the dominant view in Batavia was that forcing the Company into a privileged position in Makassar was unrealistic. After the 1655 treaty had proved unproductive, the option of forcing or luring Makassar into a dependent position became, as we saw in chapter 5, more and more attractive to the High Government. Although the four contracts of $1637,1655,1660$, and 1667 can in one sense be regarded as a relay-race of contracts written from diverging perceptions of the situation on the ground, and with diverging political ambitions for the contracts, there is also good reason to point to the August 1660 treaty as a break in this chronology.

I argue below that the notion and meaning of "treaty" underwent a change after 1655. The meaning of "treaty" in 1637 and 1655 carried far more passive

2 Ibid. 289. 
connotations than the one of 1660 . The two former contracts carried a conceptualisation of "treaty" as "agreed rules of the game to be adhered to"-whereas the latter ones held far more active connotations, namely "treaty" understood as something to be "worked with to construct an optimal interaction order." The change signalled a move towards a constructivist view of a treaty as a political instrument. It goes without saying that if the contracts were made with an eye to the local situation, the turn towards a more political, constructivist view of treaty meant a sharpening of this focus.

\section{Plan of exposition}

My emphasis in this chapter is on the August 1660 treaty, but I start the discussion with a comparison of the 1637 and 1655 contracts to corroborate my point that they can both be seen as contracts aimed at regulating by rules. I then turn to an analysis of the political constructivist contract of 1660 . All the analyses are based on the texts in Heeres' Corpus Diplomaticum.

\section{Section 2: A recapitulation of the 1637 and 1655 treaties as "soft" treaties}

The context for the treaty making in 1637 and 1655 was different, but not fundamentally so. In 1637, the Company had come to Makassar to open relations with a strategic view to ending smuggling and protecting its possessions in the Spice Islands. ${ }^{3}$ The 1655 treaty was concluded in the aftermath of a war that had been fought for the same reasons.

As for the contents of the two contracts, the major difference lay in the different role that religion was accorded in the later treaty, and the concessions that allowed for continued contact between Makassar and the Spice Islands.

The appeal to religion in the 1655 treaty was made because of the sultan's self-professed commitment to his co-religionists outside Makassar, whereas in 1637 the issue of runaways and converts were treated as issues of bilateral interaction and accordingly formulated in terms of symmetrical, reciprocal obligations. ${ }^{4}$ The 1637 treaty simply stated that the sultan obliged himself to

\footnotetext{
See chapter 4 .

4 See chapter 4 .
} 
return Company runaways while the Company committed itself to do the same with Makassarese runaways. ${ }^{5}$ The issue of religious worship was stated as a general agreement on the free right to worship according to one's own tradition. Both the Company and Makassar were "allowed to practise their respective religion without any constrictions on either side."' I have argued above that the acceptance of the concessions in the 1655 treaty might well have had to do with the pressure from the Directors for peace, but that it might also reflect the belief that the Makassarese after defeat in the war would now honour their treaty obligations. I have also argued that the willingness to accept the concessions at the time might have had to do with a cultural assumption that Sultan Hasanuddin was preoccupied with prestige and symbolic aspects of religion, and that the concessions on religion were inconsequential to the issue of political interference.

\section{The 1637 and 1655 treaties: Different, but still two of akind}

Admittedly, the Company may have achieved more in the treaty of 1637 than in 1655, but regarding the 1655 treaty as a sell-out seems unwarranted. Although it contained concessions that later proved to be loopholes, by article 8 , confirming the Company's monopoly rights, the High Government obtained what it must have considered its primary diplomatic target at the time. For after all, the treaty contained Makassarese recognition and a commitment to respect the Company's privileged position in the Spice Islands. Other concessions were insignificant compared to this vital issue. It thus seems proper to regard the 1655 treaty as a special, but still typical product of the dominating frame of diplomatic thinking in Batavia at the time. Based as this approach was on confidence in Hasanuddin's intentions to stick to his obligations, concessions could be conceded. As I have pointed out in chapter 5 , this assumption of trust radically disappeared in the first years after the signing of the 1655 treaty.

"dat bij aldien eenige Nederlanders op Maccassar quamen wegh te loopen, desselve aen haer meesters weder ter handt stellen sullen, gelijck ook eenige Maccassaren bij de Nederlanders also overcomende, aen Zijne Maij.t restitueeren moeten." 1637 treaty, Corpus Diplomaticum, 1.305.

6 "dat ijder zijn geloff zall vrij hebben, sonder daer in eenighsints gecontringeerdt te warden." 1637 treaty, Corpus Diplomaticum, 1.305. 
I find there to be a distinctive difference between the contracts signed before and after 1655. In the 1637 and 1655 contracts, the voices and viewpoints of Sultan Alauddin and Sultan Hasanuddin, respectively, are quite distinct. Many of the rulings are phrased as regulations of what the Company was allowed. In this sense, the 1637 and 1655 contracts are distinguished as agreements by which the Company partly had to take what it had been forced to accept in negotiations. In 1637 , this happened by rephrasing through negotiations. In 1655 , the concessions were thought compensated by a single article protecting the Company's basic interests. The texts of the August 1660 and November 1667 contracts, on the other hand, bear a quite different stamp, because they present detailed prescriptions for an interaction regime that was meant to serve and protect the Company's interests. This signals that in the post-1655 framework, the "treaty" was turned into something of a constructivist, political instrument. This change did not represent a return to a Eurocentric model of treaty making. It represented an intensification of the overseas contextual approach.

\section{Section 3: The switch to contractual constructivism: The dual nature of the 1660 Treaty}

\section{Section introduction: Topic and propositions}

The August 1660 treaty comprised twenty-seven articles covering all subjects from the status and position of Ambon and Banda, the role of Makassar and the Company in the regional interaction order, to the expulsion of the Portuguese and the mode of enforcing this, the handling of miscellaneous damage claims, and decisions on tariffs. It was thus a far more encompassing treaty both in size and scope than the earlier ones.

Treaty making as political construction would come to full maturity only in the treaty of November 18, 1667; but the treaty of August 1660 represented a turn in this direction. It also demonstrated an increased drive towards formulating the treaty clauses more specifically and concretely.

These turns in the August 1660 treaty were not a shift to a European standard brought overseas. The change in treaty making had to do with the shift in expectations towards Makassar as a trustworthy signatory. The aim of this 
chapter is to demonstrate how this shift towards contractual constructivism was reflected in the contents and formulations of the post 1655 treaties, starting with the break represented by the August 1660 treaty, and ending with the treaties establishing Company hegemony in 1667 and 1668.

\section{Plan of exposition}

In demonstrating the contextual imprint in the form and nature of the August 1660 treaty, I shall be concentrating on the Makassarese traffic to the Moluccas, and the issue of the expulsion of the Portuguese. In conjunction with the latter issue, I shall analyse the implicit Company invitation to the Makassarese to ally against the Portuguese, which I take to be typical of the political construction aspect of treaty making. At the end of the chapter, I shall briefly point to the changes that were made during the countersigning of the August 1660 treaty in Makassar in December.

\section{Section 4: Textual analysis of the August 1660 treaty}

\section{A treaty to be honoured, make no mistake about it}

The concluding paragraph of the August 1660 treaty notes that this is a treaty of sincere "peace and friendship" that should be "observed and honoured." The point on treaty observation was further amplified in the section on the ratification procedure. The treaty was first to be signed by the governor-general and Council and the Makassarese envoys in Batavia, and then by envoys from the High Government and the sultan in Makassar "to secure that all the points be strictly honoured." In the concluding oath swearing, the "one and only almighty and righteous God" was called upon as the final witness ${ }^{9}$ that the treaty was "agreed and confirmed." ${ }^{10}$ Compared to the 1637 and 1655 treaties, the general binding nature of the treaty was thus particularly explicated in the

\footnotetext{
"gehouden en geobserveerdt worden." August 19, 1660 treaty, art. 27, Corpus Diplomaticum, 2.176.

"In alle bovenstaende poincten des te religieuser magh onderhouden worden." August 19, 1660 treaty, art. 27, Corpus Diplomaticum, 2.176.

"met aenroepinghe van de allderheijlighste name van den eenigen allmaghtigen ende reghtveerdigen Godt." August 19, 1660 treaty, art. 27, Corpus Diplomaticum, 2.176.

"bevesstight en geconfirmeerdt." August 19, 1660, treaty, art. 27, Corpus Diplomaticum, 2.176.
} 
August 1660 treaty. ${ }^{11}$ This was a constituent factor in the formulations of the individual articles, too.

\section{Reconstructing the political regime: 1-Limiting Makassarese claims of sovereignty outside Makassar to secure the Company's interests in the Moluccas (articles 1, 2, and 3)}

The three first paragraphs of the August 1660 treaty were all concerned with delimiting Makassar's influence and rejecting its claims of sovereignty outside South Sulawesi. First, the king of Makassar was not to interfere with Buton or territories belonging to it. ${ }^{12}$ The reason given was that these territories were "lands belonging to the king of Ternate." ${ }^{13}$ The same went for Menado: The sultan was obliged to withdraw all claims of sovereignty as these areas "from old belonged" to the king of Ternate. ${ }^{14}$ The sultan also had to set aside all claims to and stop all interference with Tidore and Batjan, ${ }^{15}$ and recognise "their lands and people to be included in the treaty." ${ }^{16}$ The latter meant recognition of their autonomy as guaranteed by the Company.

\section{Comment: Idioms of "sovereignty" in articles 1, 2, and 3 and diplomatic mode}

The political arrangement in the three first articles was aimed at cutting bonds between Makassar and former allies and converting the latter into a "security" ring of independent Company-friendly states around Makassar itself. ${ }^{17}$ The diplomatic means to achieve this was to have Makassar recognise the

11 The July 26, 1637 treaty placed no emphasis on its binding nature; see Corpus Diplomaticum, 1.303 ff. Only the December 28, 1655 treaty was wederzijts onverbreeckelijck; Corpus Diplomaticum, 2.84.

12 "dat de Coninck van Maccassar moghte szijn volck haer voortaen niet en sullen bemoeijen met Butonoffte landen ende plaetsen daeronder behorende." August 19, 1660 treaty, art. 1.1, Corpus Diplomaticum, 2.171.

13 "als zijnde de eijgen landen van de Coninck Mandarhahha van Ternaten." August 19, 166o treaty, art. 1, Corpus Diplomaticum, 2.171.

14 “ook van outs hefft toegekomen." August 19, 1660 Treaty, art. 2, Corpus Diplomaticum, 2.171

15 August 19, 1660 treaty, art. 2, Corpus Diplomaticum, 2.171.

16 "Tijdor ende Bachan met hare landen ende onderdaenen des begeerende mede in dese vrede begrepen zullen zijn." August 19, 1660 treaty, art. 3, Corpus Diplomaticum, 2.171.

17 This was what was finally formalised in the 1667 treaty, see below. 
"autonomy" of these states and the "sovereignty" of their rulers. As for how they incorporated it in the treaty, neither the legal technical terms "sovereignty" nor "autonomy" were used. The terms were the more general "belonging to" or "lands of," and the mode of legitimation was by reference to historical tradition, "from old". rather than law. In neither of these cases should we propose that the Company's treaty idioms were drawn from a specifically or even typical European tradition of international law. Appeal to local diplomatic tradition is a more apt description in so far as it was the local historical tradition and power relations that the Company referred to in legitimising the new political order. Both means and modes were adopted in the November 18, 1667 treaty.

\section{Issue: Ambon, the Spice Islands-banning interference and restricting sailing rights (articles 4 and 5)}

The ban on Makassarese sailings to Ambon, made in article 4, was put in absolute terms, and made without any qualification. In contrast to what had been the case in 1655 , in 1660 there were to be no exceptions whatsoever. The article stated that "those representing the government of Makassar from now on and in the future, should not interfere in the affairs of Ambon, nor bother themselves with complaints coming from the Ambonese, under whatever pretext it might be whatsoever." ${ }^{18}$ The latter formulation of "pretext" held an implicit, but nonetheless obvious, reference to the loopholes in the 1655 treaty. Not only did this article do away with the 1655 concessions, but it also gave a barely concealed retort that the High Government now saw Hasanuddin's appeal to religion in 1655 as tactical rather than spiritual.

The barring of Makassarese influence in Ambon was made even more watertight by the demand that Makassar officially recognise the Company and king of Ternate as the "rightful overlords"19 of Ambon. Thus, Makassar also recognised that the Company and Ternate were rightfully entitled to defend and protect

\footnotetext{
18 "dat die vande regeringe van Makassar van nu voortaan haer niet sullen bemoeijen offte in eenigen delen aenmatigen eenige saecken offte claghten der Amboijnesen onder wat onder pretext het ook zouden mogen wesen.” August 19, 1660 treaty, art. 4, Corpus Diplomaticum, 2.171.

"wettige souverainen." August 19, 1660 treaty, art. 4, Corpus Diplomaticum, 2. 171.
} 
Ambon..$^{20}$ Finally, the area of Ambonese overlordship was defined by naming each island of the domain. ${ }^{21}$ Even so, these seemingly watertight treaty formulations were not considered sufficient in and of themselves. Sanctions for breaking the regulations were specified, too. This was done in article 5. A break in the sailing ban by subjects or inhabitants ${ }^{22}$ of Makassar, including people from Banda, would be met by either killing or enslaving the perpetrators. ${ }^{23}$ Vessels and goods were to be confiscated ${ }^{24}$ without protest by the Makassarese. ${ }^{25}$

\section{Comments: A further turn towards treaty formulations in the concrete and specific}

The regulation on sailings to the Moluccas in the August 1660 treaty conveyed a "no-nonsense, no-compromise" insistence that was more encompassing and radical than in the 1637 treaty, ${ }^{26}$ and stood in stark contrast to the 1655 treaty, in which the ban was formulated as a request. ${ }^{27}$ The particularities of the August 1660 treaty did not represent a return to European legal thinking or terminology. Neither article 4 nor 5 was phrased in "subtle" juridical terminology. The Company's and Ternate's joint sovereignty over Ambon was simply stated, the area was concretely defined, and sanctions for trespassing were likewise clearly and specifically stated.

\section{Securing and protecting the Company's monopoly in the Spice Islands (articles 6 -9)}

Articles 6 to 9 were all dedicated to safeguarding the Company's monopoly in the Moluccas in general. Article 6 concerned the handling of smugglers who

\footnotetext{
20 "daer met sullen laten omspringen ende gewerden." August 19, 1660 treaty, art. 4, Corpus Diplomaticum, 2.171 .

21 August 19, 1660 treaty, art. 4, Corpus Diplomaticum, 2.171.

22 “onderdanen offte inwoonderen." August 19, 1660 treaty, art. 5, Corpus Diplomaticum, 2.172.

23 "doot geslagen off tot lijffeigenen gemaackt." August 19, 1660 treaty, art. 5, Corpus Diplomaticum, 2.172 .

24 “verbeurte van de vaertuijgen en goederen." August 19, 1660 treaty, art. 5, Corpus Diplomaticum, 2.172 .

25 "zonder dat die van Makassar het zellve sullen aentrecken." August 19, 1660 treaty, art. 5, Corpus Diplomaticum, 2.172.

26 None of the repetitions or linguistic "safeguards" of "none whatsoevers" etc. were for instance, present in the 1637 treaty.

27 Art. 8, of the 1655 treaty.
} 
had successfully brought their illicit goods into Makassar. In such cases, the authorities ${ }^{28}$ in Makassar were held responsible for punishing the smugglers ${ }^{29}$ themselves or handing them over to the Company. ${ }^{30}$ At the root of these sanctions lay the familiar device of the sailing pass system, treated in article 7 , which stated that Makassarese authorities were to deny anyone not in possession of a pass the right to enter and trade. Perpetrators had to be handed over directly to the Company. ${ }^{31}$ Article 8 added no new provisions, but simply defined what products were considered contraband. The government of Makassar was not to tolerate any import or trading in the Company's monopoly products: cloves, nutmeg and mace, but should punish perpetrators in the harshest way, regardless of where they might have obtained their goods. ${ }^{32}$

The uncompromising and insistent tone in the formulation of the goods enumerated in article 8 was supplemented by legitimising the Company's monopoly as a blessing from God. The formulation went that the Company had now come to possess all the respective spices of the Eastern Archipelago "by the blessings of God." ${ }^{33}$ At the heart of this formulation was possibly a similar "conceptualisation" of God's blessings of the Company's endeavour that we encountered in the mobilising appeals of the General Instructions. ${ }^{34}$ But this might also be interpreted as a rebuttal to Hasanuddin's appeal for concessions by appeal to his religious authority in 1655 . In any case, in the August 1660 treaty, setting the reference may simply be read as: End of discussion, or, to be more precise: "Any discussion about qualifications is futile on this point."

Art. 9, was a two-part article, dealing with both the Company's conflict with Makassar over its monopoly rights in the Moluccas but also with the exclusion of the Portuguese from Makassar. I shall deal with the former first. A complementary

“Die van de Regeeringe." August 19, 1660 treaty, art. 6, Corpus Diplomaticum, 2.172.

“Lorrendrayers." August 19, 1660 treaty, art. 6, Corpus Diplomaticum, 2.172.

"gehouden wesen ... te straffen off aen de Compagnie te leveren." August 19, 1660 treaty, art. 6, Corpus Diplomaticum, 2.172.

"zonder zeebrieven van de Comp.e varende in Maccassar vermogen, (gene) haven offte negotie te verleenen, maer zullen gehouden wesen aen de Comp.e over te leveren.” August 19, 166o treaty, art. 7, Corpus Diplomaticum, 2.172. "de contraventariers rigoureuselijck sullen gestrafft worden, van waer dessellve die ook sullen mogen gehaellt offte becomen hebben." August 19, 1660 treaty, art. 8, Heeres, Corpus Diplomaticum, 2.172. "Dewijl de Compie de nagelen, nooten ende foelie door de zegen Godes nu allen onder haer gewellt heft." August 19, 1660 treaty, art. 8, Corpus Diplomaticum, 2.172.

34 See chapter 3.
} 
protection against Makassarese infringement on the Company's monopoly in the Moluccas was given by restricting the legitimate legal trading area of the Makassarese. They were not to extend their present trading activities, nor settle further east than Solor and Timor and their surroundings. ${ }^{35}$ By way of illustrating how the High Government's policy had changed in 1660, one should remember that it had at one point considered surrendering Timor to the Portuguese altogether. ${ }^{36}$

\section{Comment: constructing a defence for the monopoly by treaty}

Thus, six articles in the August 1660 treaty (articles 4-9) defined and regulated Makassar's position in relation to the Company's monopoly rights in the Spice Islands, whereas in 1655 the High Government had trusted in only one. In 1655, the High Government had relied on a general recognition of its rights in the Spice Islands and a similar general recognition of its right to defend them. By acting under pressure, and believing that Hasanuddin's demands for specific concessions originated from exclusively religious motives, the High Government had accepted a treaty with potential loopholes in its formulation on the monopoly. In the August 1660 treaty, these flaws were excised, but this was not done by reverting to European concepts of international law. It was done by a meticulous hammering out of the concrete specifics of both "monopoly" and "sanctions." The biggest challenge to the Company's monopoly, and the thorn in the side of the High Government, the Portuguese presence in Makassar, was dealt with in the same manner.

\section{Power politics and the expulsion of the Portuguese (articles 9-12)}

The Portuguese in Makassar were the most serious threat to the Company's monopoly in the Moluccas, and the heart of the 1660 treaty was their expulsion. In the August 1660 treaty, this was presented as a two-stage operation,

35 "de Maccasaren hare in de quartieren van Solor ende Tijmor ende de plaatsen daerom her in negotie niet verder en sullen vermogen uijt te breiden." August 19, 1660 treaty, art. 9, Corpus Diplomaticum, 2.172.

36 Arend De Roever, De jacht op sandelhout, (Zutphen: Walburg Pers, 2002), 216-217. 
first by neutralising any interference from Portuguese in Solor and Timor (articles 9-11), and then by an obligation laid on Makassar itself to expel its Portuguese population (article 12). Given the importance of the issue, I shall go through these articles in some detail.

\section{Articles 9-11: Neutralising the threat from the Portuguese in Solor and Timor and making it a general rule}

Article 9 and 10 laid down Makassar's neutrality with respect to the Portuguese in Solor and Timor. Whereas, as already noted, the first article defined Timor and Solor as the outer boundary of Makassarese legitimate trade, the next article brought the strategic dimension of the issue to the fore. The Makassarese in Solor were not to "support enemies of the Company wherever they might be,"37 which included supplying "men, arms, gunpowder, fuses, boats or whatever it might be." ${ }^{38}$ In article 11, this was all made into a general rule that stated that the Makassarese were not permitted to sail to any places with which the Company was at war, or where the Company was enforcing a blockade. ${ }^{39}$

\section{Summing up: Restrictions on Makassar's foreign policy and autonomy in the precautions to protect the monopoly}

Articles 9 and 10 required Hasanuddin to sign and swear that to assist any Portuguese efforts to infringe the Company's rights would be regarded as a breach of treaty, and therefore considered to be a casus belli. Absolute restrictions were put on Makassarese intervention in the Company's military affairs in the archipelago by article 11. This meant putting severe restrictions on Makassar's foreign policy and autonomy to protect the monopoly. As for form, one should note the specific phrasing and the variants of all-inclusive formulas in these articles, which in the

37 "dat de Maccassaren in de gemelte quartieren van Solor, waer het ook zoude mogen wesen, de vijanden van de Comp'e niet zullen vermogen te adsisteren." August 19, 1660 treaty, art. 10, Corpus Diplomaticum, 2.173. The "enemy" was obviously the Portuguese community on Solor.

38 "met volk, schutt, cruijt, londt, vaertuijgen, vivres offte wadt het zoude mogen wesen." August 19, 1660 treaty, art. 10, Corpus Diplomaticum, 2.173.

39 "de Maccassaren niet sullen vermogen te varen op eenige plaetsen met welker de Comp.e in vijandschap zijn, offte die zij met schepen beset zall hebben." August 19, 1660 treaty, art. 11, Corpus Diplomaticum, 2.173 . 
final analysis reflected the deep distrust of Hasanuddin that had become dominant in Batavia at the time. Again, there was no return to a more formalised legal treaty model in this, but a turn towards the more specified and concrete formulations. The same went for the expulsion of the Portuguese from Makassar.

\section{The expulsion of the Portuguese (article 12)}

When the expulsion of the Portuguese was addressed directly in article 12, it came as a de facto dictate by the Company, formulated in absolute terms: "The Sultan was to ban the Portuguese from all his domains, with all their creatures, and followers from now on and forever." ${ }^{\circ 0}$ In brief, all the Portuguese were to leave Makassar and take all their belongings with them, never to return. No modifications, no qualifications.

\section{A proposition for a reconfiguration of Makassar- Company relations following the expulsion of the Portuguese}

If the expulsion itself was formulated unambiguously enough, another less unambiguous feature of the expulsion clause was the manner in which the touchiness of the situation for the Makassarese was counterbalanced by an ideological remodelling of Makassar-Company relations. The essence of this reconfiguration was that the expulsion came as a necessary consequence of Portuguese meddling with a "natural" Makassar-Company bond of friendship. The expulsion decree itself was ultimately formulated in absolute terms, but the article started off by placing the blame for all the recent problems between Makassar and the Company on the Portuguese: "as the Portuguese alone must be regarded as the only reason for and the sole instigators of all the recent troubles and conflicts that for many years have occurred between Makassar and the Company." ${ }^{41}$ The expulsion was thus legitimised in terms of Portuguese disturbance of an implicit

\footnotetext{
40 "Soo zal de coninck van Macassar desselve (the Portuguese) met haere creaturen ende aenhanck van nu voor althoos zijne landen ende gebiedt ontseggen." August 19, 1660 treaty, art. 12, Corpus Diplomaticum, 2.173 .

41 "dewijle de Portuguese gehouden moeten warden d'eenighste oorsaek ende aenstookers geweest te zijn van alle donlusten ende quesstien, die sedert vele jaeren herwaerts tusschen de cronen Macassar ende de gem. Companie zij voorgeveallen." August 19, 1660 treaty, art. 12, Corpus Diplomaticum, 2.173.
} 
harmony between the Company and Makassar, and was in other words regarded as a just punishment for intrigue and deceit by the Portuguese. The reconfiguration of the interrelationship between the Company, the Portuguese, and Makassar thus cast the Portuguese as the bad guy against Makassar and the Company, the good guys, with the qualification that Makassar had been temporarily misled by the bad guy. This may well be seen as an invitation to a Company-Makassar alliance against the Portuguese..$^{42}$ In any case, the reordering of bilateral ties demonstrates how contractual formulations were being considered and consciously used as elements in constructing relationships. That came to the fore in a number of restitution and damage cases described in articles $13-15,18$, and 23-26.

\section{The blame and shame in damages and debt: 1-Implications of prestige distribution (articles 13-15 and 18)}

Article 12 concluded the regulation proper of the political interaction regime between the Company and Makassar. Four of the six succeeding articles (articles $13-15$ and 18 ) were all concerned with restitution claims, ${ }^{43}$ which, in turn, all held implications of prestige distribution linked to the political realignment outlined above.

\section{Article 13}

Article 13 concerns Hasanuddin's restitution claim on the Dutch for arrest of the ship Joan Baptista, and his accusations that earlier agreements on compensation due him had not been fully met. ${ }^{44}$ Both claims were met with a mix of self-righteousness and deflected blame. The treaty stated that the Company had in fact honoured its obligations in full, even though the sultan's claims were wholly unjustified. When the Company had chosen to compensate the sultan anyway, it had only done so because it wished to preserve good relations with him. ${ }^{45}$ Mimicking the redistribution of blame in article 12, the Dutch

\footnotetext{
42 To support this: See the the High Government's concers about Makassarese worries over the economic effects of expulsion of the Portuguese, chapter 8.

43 Arts. 16 and 17 concern the twin issue of run-aways and converts and will be treated below.

44 For the Joan Baptista incident, see Stapel, Het Bongaais Verdrag, $54 \mathrm{ff}$.

45 "De Compagnie het selve geensints schulldigh is geweest maer alleen betaelt heeft om met Maccassar in goede vrede te continueeren." August 19, 1660 treaty, art. 13, Corpus Diplomaticum, 2.173.
} 
emphasised that the real blame for the whole conflict around the Joan Baptista affair lay with the Portuguese, who in a devious manner had shirked their agreed obligations and still owed the sultan. ${ }^{46}$

\section{Comment}

If we look at the moral equation in the presentation of the issue here, both Hasanuddin and the Portuguese are cast as being in the wrong: Hasanuddin for setting forth unjustified claims, the Portuguese for having deviously misled him. Still, of the two, Hasanuddin comes out better, having been tricked by the Portuguese. In contrast to the Portuguese, the Company reigns morally supreme by virtue of its willingness to meet unjust demands for the sake of reaching an agreement. This implicit moral equation then has a simple lesson for the Makassarese: Switch partners and everything will be all right.

\section{Articles 14 and 15}

Articles 14 and 15 both concern the Company's compensation claim for the flight of Adrighem, who had embezzled 8,00o reals of eight, in Makassar. ${ }^{47}$ The sultan was held personally responsible and was instructed to order the arrest of the Portuguese who abetted the fugitive and hand them over to the Company for punishment. ${ }^{4}$ If he failed to do so, he was to pay 8,000 reals to the Company, on the promise that the money would be returned on the delivery of Adrighem and his accomplices. ${ }^{49}$ By holding Hasanuddin personally responsible, the High Government may have believed that he had been a party to the incident. But as it stood, the real villains were once again the Portuguese. The subject thus entailed the same prestige distribution as in articles 12 and 13 .

\footnotetext{
46 "Door de listige practijken van desselve naderh.t. niet aghtervolght offte nagecomen; en is bedragende [sum not filled in]." August 19, 1660 treaty, art. 13, Corpus Diplomaticum, 2.173.

47 See Stapel, Het Bongaais Verdrag, 60.

48 August 19, 1660 treaty, art. 15, Corpus Diplomaticum, 2.174.

49 August 19, 1660 treaty, art. 15, Corpus Diplomaticum, 2.174.
} 


\section{Courting Makassar in distrust: Articles 23-26}

After a section of articles regulating the bilateral administrative and judicial relations between the Company and Makassar in Makassar, including the grant for a permanent trading lodge (article 19), another group of articles concerning miscellaneous restitution and damage claims were included (articles 23 and 24), and article 26 simply confirming that a settlement had been reached. The respective issues were, in order: The sultan's role as guarantor for Portuguese payment for damage done to the Company's lodge (article 23) 50 $^{\circ}$ and general war damages (article 24). ${ }^{51}$ Article 25 concerned the terms of the Company's evacuation of Fort Panakkukang and the arrangement for Makassarese hostages to be held in Batavia until the treaty had been countersigned. ${ }^{22}$ In these instances, we recount a similar pattern of redistribution of blame and praise as in the above.

In article 23, the sultan should make sure that the Portuguese pay for the repair of damages to some private persons associated with the Company's lodge. ${ }^{53}$ There can be no doubt that at the time, the High Government held the view that the Portuguese actions could never have taken place without the tacit consent of Hasanuddin. ${ }^{54}$ Yet, blame was never laid on Makassar explicitly, nor did the treaty explicitly address any settlement for wrongdoing. The sultan was simply requested to see to it that the Portuguese would be held accountable. This definitely fits in with a friend-foes constellation where Makassar-Portuguese bonds were to be cut and those between the Company and Makassar tied.

The same distribution of blame applied to the compensations for the Company's military expenses in article 24. "The Sultan was to see to it that the Portuguese make good and pay damages to the Company for the considerable costs." ${ }_{55}$ Although a sanction clause stated that the gold and money brought by the Makassarese head negotiator to Batavia should be

\footnotetext{
August 19, 1660 treaty, art. 23, Corpus Diplomaticum, 2.175.

August 19, 1660 treaty, art. 24, Corpus Diplomaticum, 2.175.

August 19, 1660 treaty, art. 25, Corpus Diplomaticum, 2.176.

"De coninck van Makassar door de Portugesen sall doen vergoeden ende uitkeren de cleijne schade." August 19, 1660 treaty, art. 23, Corpus Diplomaticum, 2.175.

54 For the general distrust in Hasanuddin at the time, see Stapel, Het Bongaais Verdrag, 59-62, covering the period from January 1659 to the decision to go to war in 1660 .

55 "de Maij. Van Makassar door den Portugesen aen den Comp.e sall doen opbrengen ende betalen voor de sware onkosten." August 19, 1660 treaty, art. 24, Corpus Diplomaticum, 2.175.
} 
withheld until the matter had been settled, ${ }^{56}$ once again the implication of the general arrangement was that the basis for friendly bonds between the Company and Makassar was prepared by putting the main blame on the Portuguese.

\section{Article 25: Evacuation of Fort Panakkukang}

The expulsion of the Portuguese in article 19 and the damage claims in articles 23 and 24 were all conditioned on the Company's evacuation of Fort Panakkukang. The governor-general and Council declared themselves committed to evacuating the fort and handing it over to the sultan "as soon as the restitution claimed on the Portuguese had been made good and the Portuguese had been expelled from Makassar." ${ }^{57}$ Still another sanction was added: The Company would hold prominent envoys as hostages in Batavia until the expulsion was complete. ${ }^{58}$

The conditions and hostage arrangements attached to the handover of Fort Panakkukang demonstrate that although there was an element of courtship towards Makassar built into the August 1660 treaty, it was one based on conditional trust. That the Company stood for an engagement within reason in 1660 is amply demonstrated by the calling back of the touchy concessions made in the 1655 treaty.

\section{Correcting the mistakes of 1655: Regulations on runaways and converts (articles 16 and 17)}

Articles 16 and 17 of the 1660 treaty were dedicated to the issue of runaway Company servants and how to handle the converts among them. These articles thus concerned not only jurisdiction, but the issue of religious co-existence. As such, they were ripe with implications for both political and cultural prestige, not least because these concerned the issue of religion, which had served as

\footnotetext{
56 "hier aen de Comp.e ter handt gestalt ende gelaten het goudt offte getellt dat d'Heer gesant Poepoe." August 19, 1660, treaty art. 24, Corpus Diplomaticum, 2.176.

57 "soo haest de bovengeroerde possten gellts door de Portuguesen getellt ende opgebraght. Ende desselve voordt uijt Macasar geset zullen wesen." August 19, 1660 treaty, art. 25, Corpus Diplomaticum, 2.176.

58 "tot haere verseckeringh gestellt zall hebben eenighe gequaliiceerde ostagiers tot genoegen van de voorschreven Nederlandsche gesanten." August 19, 1660 treaty, art. 25, Corpus Diplomaticum, 2.176.
} 
Hasanuddin's grounds of appeal for the concessions gained in 1655. The substance of article 16 was that the sultan was obliged to return all runaway Company personnel. ${ }^{59}$ In essence, the article thus only replicated what had earlier been agreed in the 1637 and 1655 Contacts. But the August 1660 formulation of the ruling was far more elaborate and specific. First, the category "Company runaways" was defined as "all those who from time to time had run away (from the Company) and settled in Makassar itself or its surroundings, and those who would defect from the Company from this time." ${ }^{60}$ As if this did not suffice, the "all" was further spelled out in the specific to include "Dutch as well as blacks, slaves as well as free." ${ }^{61}$ This added extra specificity is indicative of how the decrease in trust had led to an increase in observance of the need to close any loopholes in the formulation of treaty clauses. There was more to it, too.

\section{A 1660 convert concession}

One qualification was added to the seemingly watertight ruling on the runaways in article 16. The Makassarese envoy, Popoe, had reservations about the inclusion of converts in the sultan's obligation to return runaways. Popoe noted that as an envoy he was not in position to decide on the matter without further deliberation with the sultan himself. ${ }^{62}$ The solution to Popoe's reservation was pragmatic. It was agreed that a final decision must be postponed until the matter was finally settled during the counter-signing session with Hasanuddin in Makassar. ${ }^{63}$

\section{Article 17}

So even in 1660 a partial concession was granted. But the August 1660 concession was not at all comparable to what had been agreed to in 1655 . The Company's principle, uncompromising position on the issue of converts was made clear in

59 “de coninck van Macassar aen de Compagnie sall doen wederom geven en restitueeren." August 19, 1660 treaty, art. 16, Corpus Diplomaticum, 2.174.

60 "alle de gene dat die oijt offte oijt van haer zijn weghgelopen ende in Maccassar offte het gebied gevonden worden offte die nogh nae dese $\mathrm{t}$ eenigen tijde in Maccassar van de Comp.e sullen weghgelopen." August 19, 1660 treaty, art. 16, Corpus Diplomaticum, 2.174.

61 "zoo Nedelanders, als swarte, Zoo lijffeijgenen als vrije." August 19, 1660 treaty, art. 16, Corpus Diplomaticum, 2.174.

62 August 19, 1660 treaty, art. 16, Corpus Diplomaticum, 2.174.

63 "dat de Heer gesant Crain Poepoe daeronder niet en heft geliven te begrijpen den gene die reede de Moorsche religie aengenomen ende hebben laten besnijden, maer dat het sellver voor de Koninck zoude blijven gereserveerdt." August 19, 1660 treaty, art. 16, Corpus Diplomaticum, 2.174. 
the elaboration of the issue in article 17. Here it was emphasised that henceforth no exception was to be made for converts, who were to be "handed over on par with the other renegades, disregarding any religious conviction or conversion." ${ }^{4}$ The dominant signal in the 1660 treaty was that so far as the Company was concerned, there were to be no more pretexts by appeal to religion.

\section{Chapter conclusion}

The August 1660 treaty had a dual nature. On the one hand it represented a body of specific rulings that were meticulously worked out to meet the challenges as the High Government saw them at the time, namely that the sultanate would continue to pursue its goals in the Moluccas unless prevented from doing so. A political framework was laid down with the purpose of containing and, if necessary, pacifying Makassar. This contractual framework did not represent a variant of European legal sophistication brought overseas. It represented a pragmatic shift towards a new conception of the overseas context of treaty making

The 1660 treaty showed the whip in the Company's diplomatic hand. Yet, there was another open, outstretched diplomatic hand, too. The tenor of the comments on moral blame and praise in the articles on restitution claims was that the Company, although the wronged party, was also the party trying to clear up the mess. By holding up the Portuguese as the ultimate wrongdoers, a moral hierarchy was constructed in which the Company reigned at the top, the Portuguese at the bottom, and Makassar in between. It is difficult not to interpret this other than as an invitation for a Makassarese-Company bond that excluded the Portuguese.

Although this was to prove as illusory as it had been in 1655 , my point in the above analysis is that both the whip hand and the open hand were part and parcel of an pragmatic diplomatic approach towards Makassar that had come about partly as a reaction to the disillusionment over the results of the 1655 treaty. But above all the August 1660 treaty represented a shift in the overall conceptualisation of treaty in which the latter had come to take on a stronger, politically-instrumental meaning.

\footnotetext{
64 "Sullen in alle manieren wederom gegeven worden zonder aenschouw van religie offte besnijdenisse." August 19, 1660 treaty, art. 17, Corpus Diplomaticum, 2.174.
} 



\section{8}

\section{Learning to Make Treaties, Two Treaties of Political Hegemony, 1667-68}

\section{Section 1: Chapter introduction}

The treaties that Cornelis Speelman concluded during his 1667-68 campaign in the eastern quarters can be split into three: The treaties concluded in the Moluccas and with Buton before the fall of Makassar in November 1667, which established a "security ring" around Makassar; the November 1667 treaty with Makassar, which laid down and regulated the Company's hegemony over Makassar; and, finally, the March 1668 treaty with Tello, which secured the latter's commitment to the November 1667 treaty. Taken together, these secured the Company's overlordship in South Sulawesi and the Eastern Archipelago. The way this political hegemony was constructed by treaty forms the topic of this section.

\section{Section propositions}

Both in the substance of the actual regulations as well as in their textual formulations, these treaties were drafted with a sharp eye to the main challenge of the new hegemonic political order, namely how to keep your friends close and your (former) enemies under even closer control. In this section, I argue that the challenges of establishing a hegemonic political order rejected Eurocentrism and were de facto met with hyperpragmatism.

It is a basic assumption in the analysis that neither the treaties with the outer islands nor those with Sulawesi polities should be considered in isolation, but as integrated parts of the same hegemonic structure. But, one 
must separate the parts to see the whole. Also, if all the treaties under discussion here formed integrated parts of the Company's hegemonic structure, variations in their form and content are to be found. These particularities reflected variations in local conditions, and thus represented adaptations made for the preservation of the hegemonic order. My analysis will shift between the general and the specific dimensions of the construction of hegemony.

\section{Plan of exposition}

The treaty complex that secured the Company's hegemony over South Sulawesi and in the Moluccas, was to a large degree the work of Speelman. As for his doings in Makassar and the Eastern Quarters specifically, I sketch the contents of the separate treaties concluded by or on behalf of Speelman and the Company in Buton and the Moluccas between January 4 and June 25, 1667. ${ }^{1}$ Here, I analyse the June 25 treaty with Buton in some detail, as it illustrates how a specific local political challenge was tackled by treaty. I then go on to analyse the contracts concluded in Sulawesi, namely the November 18, 1667 treaty with Makassar and the January-March 1668 treaty with the Tello, with an emphasis on the former. All the quotes and references to the treaty texts are taken from Heeres compilations.

\section{Section 2: The outer islands treaties January-June 1667: Articulation of bonds of vassalage}

The treaties between the Company and miscellaneous Moluccan islands concluded by or on behalf of Speelman between January and June 1667 comprise, in chronological order, a treaty of surrender to the Company by a Makassarese army in Buton on January $4,{ }^{2}$ a treaty of Tidorese recognition of Company overlordship concluded on March 29, ${ }^{3}$ a treaty of pacification and alliance with the king of Tibor on the north coast, also dated March 29, ${ }^{4}$ and three

\footnotetext{
From now on: "The treaties with the outer islands" or "Outer Islands treaties."

Makassar, January 4, 1667, Corpus Diplomaticum, 2.346-48.

Molukken, March 29, 1667, Corpus Diplomaticum, 2.193, 348-54.

Makassar, March 29, 1667, Corpus Diplomaticum, 2.354-55.
} 
successive treaties recognising Company overlordship, by Ternate, dated March 30,5 Batjan April 12, ${ }^{6}$ and Buton, June 25. ${ }^{7}$

The rationale for all these agreements was to establish a security ring of Company allies around Makassar. As such, they were all contracts of vassalage to the Company. They typically detailed restrictions on and procedures for diplomatic interaction with third parties, stated military alliance obligations towards the Company, and gave the Company a veto or final say in the procedure for leadership succession. ${ }^{8}$ For reasons of economy of space, I shall restrict my analysis of these treaties to the issue of vassalage to the Company.

The nature of the political relationship between the Company and the local treating party was implied in the preamble and the concluding confirmation clause, but was usually explicitly stated in a separate articlermally in the middle or at the end of the treaty. ${ }^{9}$ As a rule, it was preceded by regulations for the monopoly regime, restrictions on commercial and diplomatic agreements with third parties, and obligations of the treating party in time of war. The standard formulation of vassalage to the Company typically contained a declaration of recognition of the Company's overlordship by the local prince and his nobles as follows: "Further on the king and his nobles declare that they deliver themselves, their domain and their subjects into the hands of the Company as their protector and defender." ${ }^{10}$

\section{Buton as an exception confirming the rule}

Before commenting on the treaty position of Buton, it must be pointed out that Buton is practically touching Sulawesi and is closer to Macassar than Ternate,

5 Molukken, March 30, 1667, Corpus Diplomaticum, 2.356-59.

6 Molukken, April 12, 1667, Corpus Diplomaticum, 2.359-63.

7 Boeton, June 25, 1667, Corpus Diplomaticum, 2.363-68.

8 The January 4 treaty with Buton and March 29 treaty with the king of Tibor were treaties of a predominantly military nature, whereas the four others more extensively comprise regulations in the economic-commercial and political fields.

9 In 7 th position out of 17 unnumbered clauses of the March 29 treaty with Tidore (Corpus Diplomaticum, 2.350), 5th position out of 10 in the March 30 treaty with Ternate (Corpus Diplomaticum, 2.357), 6th position out of 13 in the April 12 treaty with Batjan (Corpus Diplomaticum, 361). For the June 25 treaty with Buton as a special case, see below.

10 Wijders verclaren opgenoemde Coningh ende sijne Groote hun zelve, hare landen ende onderdanen te stellen en over te draagen in handen ende onder bescherminge van de generale Compagnie, dezelve mits desen erkennende voor hare schut- en schermheer." Treaty with Tidore, March 29, 1667, Corpus Diplomaticum, 2.350. 
although, it was traditionally under Ternatean control. As we shall see below, the latter was a fact that the Company re- incorporated in its treaty relations with the island.

The June 25 treaty with Buton ${ }^{11}$ presented a different case as there was no separate paragraph describing Buton's vassalage to the Company. The treaty followed the standard litany of issues up to and including the ban on receiving envoys from third parties. But it then jumped directly to the rules regarding the procedure for succession. The reason was simply that the vassalage function was secured precisely by the regulations on the succession procedure, over which the Company and Ternate, which was formally placed on par with the Company, ${ }^{12}$ were accorded joint control.

\section{Securing political dominance and stability in Buton by control over succession}

Article 7 of the treaty with Buton stated that the nobles of Buton were obliged to inform the Company immediately in the case of the death of their king. ${ }^{13}$ Delegates from both Ternate and the Company were then to be present for the council of the realm's election of a new king, ${ }^{14}$ and the new king must in their presence swear an oath of obligation on a copy of the June 25 treaty. ${ }^{15}$ In addition, the members of the council of the realm were required to swear that they would never depose the present king and elect another, unless given permission to do so by Ternate and the Company. ${ }^{16}$

The Company's and Ternate's rights of interference and control over the government of Buton went further still. Both were accorded veto rights with

11 Treaty with Buton, June 25, Corpus Diplomaticum, 2.363-69.

12 Treaty with Buton, June 25, Corpus Diplomaticum, 2.368.

13 "Indien den coning van Bouton aflivigh wierd, dan sullen de rijxraden daarvan ten eersten kennisse aan den coning van Ternata ende de Compagnie moeten doen." Treaty with Buton, June 25, 1667, Corpus Diplomaticum, 2.366.

14 "van beijder sijde gecommitteerde mogen worden gesonden, die met de Rijxraad een ander in des overledens plaatse sullen verkiesen." Treaty with Buton, June 25, Corpus Diplomaticum, 2.366.

15 "alvoren bevestight te worden, tot onderhoudinge van dit contract aan de coning van Ternata en de Compagnie in handen van voorschreven gecommiteerde den eed van getrouwighheijt sullen doen." Treaty with Buton, June 25, Corpus Diplomaticum, 2.366.

16 "en als wanneere oock de Rijxraden aan de nieuwe coningh bij eede getrouwheijt sullen beloven, zonder dat de Rijxraden ooijt vermogen zullen een Coningh of te stellen en weder een ander in plaatse te kiezen als met toestaan van de coning van Ternate en de Compagnie." Treaty with Buton, June 25, Corpus Diplomaticum, 2.366. 
respect to the sacking of high officials of the realm. Neither the king nor members of the council of the realm were permitted to "sack" any prominent minister without first conferring with the king of Ternate and the Company, who would jointly look into the matter. ${ }^{17}$

So, the Company and Ternate secured an absolute power to intercede for themselves with respect to both the king and the upper echelon of the Butonese government. But the reach of political control according to the treaty went deeper still: fealty to the treaty by new officials in the Butonese government, whether in high or low positions, was secured by the inclusion of a paragraph stating that they had to swear an oath of loyalty to the June 25 treaty on the Koran. ${ }^{18}$

In case these precautions for guaranteeing a pro-Company regime in Buton were insufficient, it was added that the Company and Ternate in cooperation with the council of the realm were accorded the right to depose any Butonese king who contravened the treaty, and replace him with one who would honour it, without any objection whatsoever. ${ }^{19}$

\section{Conclusion: Buton and the other outer islands: Exception and rule}

The elaborate checks on the rulers of Buton must be explained in terms of context. Speelman's "chain of security" around Makassar depended on the endurance of the peace he had negotiated between Ternate and Tidore. ${ }^{20}$ To protect it, he had to please Ternate, which had claims on Buton. ${ }^{21}$ Considering the ambivalent behaviour of Buton after the surrender of the Makassarese forces in January 1667 , it could not have been too hard to make Company recognition of Ternatese

17 "Den goegoegoe ofte andre diergelijcke hooghe officialen uijt hare bedieninge sullen vermogen te rucken met instellinge van andre, maar gehouden wesen de clagten, diese tegen een soodanigen hebben, aan de coninck van Ternata ende de Compagnie bekent te doen, om nevens hun daar in en over gedisponeert te werden." Treaty with Buton, June 25, Corpus Diplomaticum, 2.366.

18 "en is te verstaan dat sulcke hooghe officialen, oock andere mindere Rijcxgrooten, nieu in bedieninge komende, althoos de getrouwe onderhoudinge van dit contract op den Alcoran sullen besweeren." Treaty with Buton, June 25, 1667, Corpus Diplomaticum, 2.366.

19 "Maar off het geviele, dat den coning van Bouton tegens dit contract of andersints sich quame te buijten te gaan, dan sal de coning van Tarnata ende de Compagnie met de rijcxgroten van Bouton vermogen soodanige coning aff te stellen en in zijn plaatse een ander te verkiesen, sonder eenigh tegenspreecken." Treaty with Buton, June 25, 1667, Corpus Diplomaticum, 2.366.

20 See Stapel, Het Bongaais Verdrag, $119 \mathrm{ff}$.

21 See Corpus Diplomaticum, 2.363, introduction to Treaty with Buton, June 25, 1667, referring to Valentijn 83, DRB 1666-67 112, 115 . 
influence in Buton a reward for Ternatese loyalty. In the Buton treaty, this was resolved formally by the inclusion of the Ternatese as a party to the treaty at the cost of a separate declaration of Butonese vassalage to the Company. Still, if the June 25 treaty was not how the Company typically secured political control, the outcome was the same. The primary concern in the treaty making was the practical functionality of Company control, not principled legality.

\section{The meaning of sequence}

The fact that the article describing the polities' vassalage to VOC followed rather than preceded those specifying restrictions on foreign trade, diplomatic interaction, and military obligations is illustrative of a practical-overseas contextual mode of thinking about treaties. If we were to subscribe to Andaya's propositions, the sequence would have been turned around, that is the treaties would have started off with a general description of the relationship between vassal and overlord, and then deductively gone on to describe the obligations that followed from this legalistic relationship. The mode in the outer island contracts was, however, to start with the concrete economic, politico-diplomatic, and military regulations, and work up to the overarching vassalage commitment that in effect provided these regulations their legitimacy. The Company did not "believe" in "treaties" in the abstract at the time; it practised treaty making according to a casuistic, concrete, and specific approach. This is the impression one gets from reading the treaty with Makassar of November 1667, too.

\section{Section 3: Company hegemony in the November 18,1667 treaty with Makassar \\ Presentation of the November 18 treaty}

The November 18, 1667 treaty with Makassar numbers 30 articles in all, with article 9 and 11 left blank. Article 1 simply stated that all regulations of the August 1660 treaty were considered incorporated in the 1667 treaty with the standard qualification "in so far as they did not contradict regulations in the latter." ${ }^{22}$ Article 30 laid down the swearing and countersigning procedure.

22 "in alle haare deelen en poincten sodanigh naar gevolgt warden, voor soo veel die in desen niet en werden wedersproocken." November 18, 1667 treaty, art. 1, Corpus Diplomaticum, 2.371. 
Thus, with twenty-six original articles of substance, and the August 1660 treaty included, the November 1667 treaty was the most comprehensive treaty concluded between Makassar and the Company. ${ }^{23}$ Many of its regulations were but elaborations and amplifications of regulations from the earlier treaty. The real originality of the November 1667 treaty lay in its being a governmental treaty cementing the Company's position as Makassar's overlord and the political readjustments both in Sulawesi and the outer islands that followed from it.

\section{Contents by categories}

The regulations in the respective articles of the November 1667 treaty can be subsumed under the following three main headings: "Restitution and debts" (articles 3, 5, 13, 17, and 28), "the commercial regime" (articles 8 and 12), and articles that directly or indirectly concerned Makassar's position in the postwar political order. The latter can be further grouped into subcategories such as "Restrictions on interaction with third-party Europeans," including the expulsion of the English (article 6 and 27), "Restrictions on contact with and rejection of claims to sovereignty over local states in the archipelago" (articles 10 and 14-17), and finally a cluster of articles that laid down miscellaneous interaction issues in more specific detail (articles 18-25).

Of special relevance in my context are all the explicitly political articles and the political implications of some of the non-political ones, which helped construct and support the Company's hegemonic position. That goes not only for Makassar itself, but for the whole of South Sulawesi and the Eastern Archipelago, as all the treaties concluded with the outer islands between January 4 and June 25 were incorporated as an integral part of the political system given in the November 1667 treaty. $^{24}$

The hallmark of the November 1667 treaty thus lay in fitting a lord-vassal relationship between the Company and Makassar into a broader network of Company-dominated alliances. Although there were political implications in, for instance, the regulation of the commercial regime in articles 8 and 12, among others, I shall for reasons of space concentrate on the articles

\footnotetext{
23 As we recall, taken in isolation the August 1660 Treaty won the day by one, the 1637 treaty numbered twelve articles, the December 1655 eight. 
that explicitly regulated the political interaction regime, and those whose implications are so special that they need explicit comments. The March 9-31, 1668 treaty between the Company and Tello mainly confirmed the latter's commitment to the November 1667 treaty. I shall analyse it with a focus on its paternalistic tone and form.

\section{Hegemony in the explicit political regulations of the 1667 treaty: Getting rid of the other Europeans}

The first step towards Company hegemony was the expulsion of the Europeans from Makassar. Expulsion of the Portuguese had, as we have seen, been agreed to in $1660 .{ }^{25}$ But due to Makassarese negligence or intentional delay in carrying out this obligation, it remained an issue in 1667. The formulation of the expulsion of the Portuguese in 1667 left no doubt about the Company's insistence that the measure must now be carried out. The Makassarese government was "to see to it that the Portuguese with all their following be expelled as agreed in the prior treaties, without any exceptions or any excuses that the Makassarese government might come up with., ${ }^{26}$ In one stroke, the 1667 treaty both reproached the Makassarese for not having followed up the expulsion terms of 1660 and made it clear that the terms were non-negotiable.

Still, there was the matter of the English, who also had to be expelled. Because this was a new treaty issue, it needed to be justified. But the legitimation itself was not new. The rationale for the expulsion of the English in 1667 was the same as it was for the Portuguese in 1660. ${ }^{27}$ The blame for the recent troubles and war was placed on English. The text started: "as the English must be held as the major troublemakers and be held responsible for the [Makassarese] breaches of contract," ${ }^{28}$ and logically ended up with the conclusion that they must be immediately expelled: "so shall the [Makassarese]

\footnotetext{
25 See above.

26 "Sullen als noch doen vertrecken, in conformiteit van de laatse gemackte contracten, alle Portuguesen met haaren aenhang, gene uitgesondert, waar die onder de regeringe van Macassar worden gevonden." November 18, 1667 treaty with Makassar, art. 6, Corpus Diplomaticum, 2.372.

27 See above.

28 "dewijle de Engelse gehouden moeten worden voor de groote aanstookers en voroorsaackeren van het breecken van voorschreven contracten." November 18, 1667 treaty with Makassar, art. 6, Corpus Diplomaticum, 2.372.
} 
government expel the English and their followers at the earliest possible moment from its jurisdiction." ${ }^{29}$

\section{Comment: A moral legitimation of politics}

Article 6 contained two specific expulsion orders for the Portuguese and the English. The wording regarding the expulsion of the Portuguese referred to the signed treaty of 1660, and the juridical aspect needed no elaboration. Still, there can be little doubt that there was a moral aspect involved, implicit blame being put on the Makassarese for not having carried out their contractual obligations in the first place. Regarding the English the moral blame was made explicit, as it had been with the Portuguese in 1660. The English had to pay for their deviousness, which, by implication, had ravaged the "harmony" that would otherwise have been the normal state between the Company and Makassar. This justified the expulsion while putting the Company in a favourable moral light as a more trustworthy partner than the English. These kinds of implicit and explicit moral judgments are in fact more characteristic of the treaty text than are references to law. Why this is so may well be because the former was more relevant to the rearranging of friend and foe relations than the latter.

Merely stating the Makassarese obligation to expel the Portuguese and the English was not regarded as sufficient, however. It was also added that the expulsion of both parties was permanent and incontrovertible. The possibility that any persons of these two nations should ever be allowed to traffic or trade again in the domain of Makassar was expressly denied..$^{30}$ Finally, the exclusion so outlined for the Portuguese and the English was extended to apply to people of all European nations, formulated in the same uncompromising manner. The Makassarese government was "never again to allow or permit any trade or contact with any other European nations or their representatives whosoever

29 "soo sal de Regeringe die met haaren aenhang met de aldereerste occasie mede van onder haar jurisdictie doen wegh gaan." November 18, 1667 treaty, art. 6, Corpus Diplomaticum, 2.372. At the end of the treaty, in art. 27, it was emphasises that "the king should not hinder the Company's evacuation of the English to Batavia," November 18, 1667 treaty with Makassar, art. 27, Corpus Diplomaticum, 2.379. "sonder dat ymant van de voorschreven natien ofte hare creatuuren oijt of noijt naar desen in enighe plaatse onder den Maccassaren gebiet weder tot negotie off anders geadmittert sullen mogen werden." November 18, 1667 treaty, art. 6, Corpus Diplomaticum, 2.372. 
they might be, or in whatever way they might present themselves, with no exceptions whatsoever." ${ }^{31}$

\section{Comment: form and content in the exclusion articles}

Apart from its moral aspect, the exclusion article demonstrates what might be regarded as an obsessive determination to make the rulings unambiguous and watertight against creative interpretation or claims to have misunderstood them on grounds of ambiguity. The linguistic means to achieve clarity were simplicity of phrasing, repetition, and pre- emptive amplifiers such as "whosoever," "whatsoever," and, last, "with no exceptions whatsoever," as in the above. These features do not necessarily point to a European heritage of treaty making any more than does the moral dimension in the article. More readily at hand seems to be the need to interpret them as originating from the Company's prior experience of treaty making with Makassar.

\section{Article 10: The regulations for military backup and security}

Watertight treaty formulations counted for little if one did not hold a military position to block any new Makassarese military build-up and support the threat of sanctions. The "mistake" of prematurely handing over military positions in $1660^{32}$ was not repeated in 1667. Article 10 laid down the specifics of the military system to back up the Company's hegemony. First, the Makassarese were to dismantle all coastal forts specified by name, as these were "primarily directed against the Company." ${ }^{33}$ Only Fort Sombaopu was to remain, but then only to serve as the sultan's residence and stripped of any military function. Second, no new fortification work could be undertaken in the future without the Company's sanction. ${ }^{34}$

31 "nimmermeer ergens onder haar gebiet nu off naar desen ter negotie off anders mogen inlaaten, admitteren of vergonnen eenige andere Europieanse natie of yimant van harent wegen, ' $t$ sij wie se oock zijn, off hoese moghte genoemt warden geen uitgesondert." November 18, 1667 treaty, art. 6, Corpus Diplomaticum, 2.373.

32 See above.

33 "meest reflecteren om te dienen tot versterckinge tegen de Compagnie." November 18, 1667 treaty, art. 10, Corpus Diplomaticum, 2.374.

34 "sonder dat daarnaar desen enige nieuwe daar ter plates off elders weder mogen gemaeckt warden, ten ware met gemeen goetvinden van de Compagnie." November 18, 1667 treaty, art. 10, Corpus Diplomaticum, 2.374 . 
In conjunction with the Makassarese evacuation of Fort Ujung Pandang and the Company's takeover of it as Fort Rotterdam, a "security" zone around the fort was made by miscellaneous regulations. ${ }^{35}$ These measures would guarantee the Company's security in the bilateral axis with Makassar, but the Company also had to make sure that Makassar would not find local allies in South Sulawesi or in the outer islands to rally against it. In South Sulawesi, this was done by transferring bonds of allegiance from Makassar to the Company. As for the outer islands, it was done in the same manner or by strengthening already established bonds with the Company. Thus, one alliance structure was dismantled and a new one erected in which ties to Makassar were transferred into the hands of the Company. It took four articles, 14 to 17 , to do this for the outer islands. I shall analyse them one by one.

\section{The outer security circle: Bima}

The first link in the outer chain of security that the Company built was Bima, treated in article 14. The article simply stated that the king and nobles of Makassar were "from now on not to interfere with the land of Bima or its belongings." 36 This would have done for substance, but the position of Bima as an area of noninterference for Makassar and as part of the Company's exclusive sphere of interest was elaborately worked out and repeated in the succeeding phrase, which states that Makassar must "let the Company conduct its business there at its own discretion and never, in any way, directly or indirectly, in words or deed, acting against the Company." ${ }^{37}$ Such was the linguistic mechanism of alliance cutting and retying. It was formulated concretely yet simply: Makassar was from now on not allowed to interfere. The Company must run its business undisturbed. No general principles were pointed to. No reference to international law was applied to justify it. It was a simple statement of an absolute, watertight rule.

35 Such as regarding inhabitants and local trade close to the fort, transferring jurisdiction in all inter Company-village affairs to the Company; November 18, 1667 treaty, art. 10, Corpus Diplomaticum, 2.374 .

36 "niet sullen mogen te bemoijen met 't lant van Bima en resort." November 18, 1667 treaty, art. 14, Corpus Diplomaticum, 2.375.

37 "maar de Compagnie daar met late gewerden naar hun welgevallen, sonder de selve nu of oijt na desen, op d'een of d'ander wijse, directeleijck of indirectelijck met raadt off daadt te comen tegens de Compagnie." November 18, 1667 treaty, art. 14, Corpus Diplomaticum, 2.375. 


\section{Article 16: Buton}

In article 16, Makassar's claims on Buton were denounced and the island was implicitly made an integral part of the Company's security ring around Makassar. However, the arrangement was introduced by a damage claim. The sultan was first to give restitution to Buton for manpower taken in a previous raid. ${ }^{38}$ The political arrangement simply read that Makassar was "now and never again to raise any claims on the lands of Buton whatsoever, and renounce such claims now and forever." 39 This was a slight variation on the renunciation clause for Bima, sharing the linguistic hallmark of emphasis by repetition, and phrases blocking appeals to exceptions.

\section{Article 17: Ternate}

The article respecting Ternate started off, as in the case of Buton, with a restitution claim made on Makassar, which was followed by a renunciation of any Makassarese claims to the lands of Ternate. The restitution claims specified the compensation, in numbers and types, for men raided and weapons. ${ }^{40}$ The political renunciation part was explicit, too; giving the names of each area and island for which Makassar was to forego any claims of sovereignty.4 ${ }^{41}$ The prohibition of Makassarese interference in Ternate was covered for the present and future: "the esteemed Government of Makassar wholeheartedly pledged to renounce [any claims of influence] and never again trouble the king of Ternate." ${ }^{42}$ It should be safe; at least there was no ambiguity involved.

It is noteworthy that the legitimacy of the claim, as in the August 1660 treaty, was justified by an appeal to historical continuity and tradition. The Company's

38 "Sullen aen den Coninck van Boeton ten eersten vergoeden en restitueren alle soodanige menschen als met laesten in een overval den Maccassaren in dat lant gerooft." November 18, 1667 treaty, art. 16, Corpus Diplomaticum, 2.375-76.

39 "sonder nu off oijt nimmermeer naar desen te houden off te hebben eenige de alderminste pretentie op op eenige van de landen van Bouton, daar van bij desen renuncierende." November 18, 1667 treaty, art. 16, Corpus Diplomaticum, 2.376.

40 "De geroofde menschen van Xulas, en daar beneven 10 stukken ijser canon, 2 metale prince stucken en 3 bassen, etc." November 18, 166, treaty, art. 17, Corpus Diplomaticum, 2.376.

41 "Van alle gepretendeerde eigedommen op de eijlanden Saleijer en Pantsiano, als mede op de gantsche Oostkust van Celebes..., d'eijlanden Bangaij en Gapij, als andere.” November 18, 1667 treaty, art. 17, Corpus Diplomaticum, 2.376.

42 "en de welcke de hooggemelte Regeringe van Makassar opregtelijck afstaat, belovende nimmermeer naar desen de coninck van Ternate te turberen." November 18, 1667 treaty, art. 17, Corpus Diplomaticum, 2.376 . 
recognition of the Ternatese claim was based on that the areas in question had "belonged to the king of Ternate from old." ${ }^{43}$ By denouncing the legitimacy of any Makassarese claims on these areas and supporting the legitimacy of the Ternatese claims, the special relation between the Company and Ternate as allies in the outer island contracts was obviously reaffirmed, but it was supported by reference to the local political order of old.

\section{Summing up and comments: The articles cutting bonds of alliance to the Makassarese and transferring them to the Company}

The formulaic language regarding the severance of Makassarese claims and bonds of overlordship in the areas covered in articles 14, 16, and 17 is consistently concrete and specific. No technical terms of law or general principles or derivatives of general juridical abstracts like "sovereignty" are involved. This indicates that these articles were drafted within in a mental framework of defining specific, concrete rights more than in terms of deducing them from general principles of law. Symptomatic of the former empirical, casuistic approach is that two of the three articles dealing with Makassar's renunciation of political ties start off with a damage claim made on Makassar to be paid to the offended parties.

Another aspect of the introduction by damage claims on Makassar is that it likely helped emphasise the shift in alliances and relative positions of Makassar and the Company in the regional hierarchy that was taking place. Any restitution claim, by definition, involved reconfiguring an original asymmetry. In the cases above, Makassar was identified as the original wrongdoer, and the victims were compensated by Makassar thanks to the mediation of the Company as overseer. The restitution claims made on Makassar on the one hand thus signified a break in the old master-servant relationship between Makassar and its former vassals even as it validated the position of the Company as the new overlord. The same kind of logic and arrangements were applied when it came to the rearrangement of political relations and Makassar's new position in the political regional system in South Sulawesi itself.

43 "van outs de croone van Ternate in eijgedom compterende." November 18, 1667 treaty, art. 17, Corpus Diplomaticum, 2.376. 


\section{Section 4: Restructuring the political geography of South Sulawesi by treaty}

The alliance with Arung Palakka and the Bugis was what made the victory over Makassar and the remapping of the political landscape of South Sulawesi possible in 1667 . It took eight articles-18 to 25 -in all to inscribe the new political order in the treaty. I shall go through them one by one, with the aim of pointing out their case- conditioned, instrumental nature.

\section{Article 18: Rewards to the Bugis allies and Makassarese recognition of autonomy for Bone and Loeboe}

The restructuring of the political map of South Sulawesi rested on Makassar's recognition of full autonomy for the Company's Bugis allies, Bone and Loeboe. It was inscribed in the 1667 treaty with the following wording: "Furthermore the honourable (Makassarese) Government renounces all claims of overlordship over the lands of Bone and Loeboe, recognising their leaders as autonomous royals and rulers." 44 In addition, the renunciation was reinforced by the sultan's personal oath, in which he committed himself to have "no claims whatsoever" 45 on those areas.

\section{Article 19: The punishment of Laijo and Bancala for siding with Makassar against the Company}

If the reward for the Company's Bugis allies was secession from Makassarese overlordship and recognition of autonomy, those realms that had sided with Makassar such as Laijo and Bancala paid a price. Both states were required to renounce and hand over parts of their domains that the Company had conquered during the war. These areas were to be "recognised by the Kings of Laijo and Bancala as autonomous parts with autonomous rulers and lords

44 "Voorts renuncieert de hooggemeldte Regeeringe van alle heerschappije over de lande de Bougijs en Loewoe, deselve lantheren erkennende voor vrij geborene coningsprincen ende heeren." November 18 , 1667 treaty, art. 18, Corpus Diplomaticum, 2.376. 
... where they themselves from now on and for ever could make no claims of authority." ${ }^{46}$ In short, the winners, the Company and its allies, took what they considered fair to take. The ruling represented an application of the rule of the rights of conquest by sword pure and simple. That rule was applied to the areas treated in article 20 , as well, where the principle was made more explicit.

\section{Article 20: Elaborating territorial rearrangements as legitimate by rights of war}

In article 20, the Company and allies stripped Makassar's authority over "the lands between Boeloe-Boeloe to Turate" and further down to Bonaija" on basis of the "rights of conquest in war." 47 These lands from now on were to be "recognised as having won their independence and remain autonomous and free." ${ }^{48}$

\section{Summing up: Transfers of sovereignty and territory}

The two cases of redistribution of sovereignty above came as result of the Company's war with Makassar and its allies. Their legitimation by right of conquest can hardly be regarded as uniquely European; it is for instance hard to believe that such transfers of domain and sovereignty would be incomprehensible to the local actors. ${ }^{49}$ In other words, the Company's treaty regulation on this issue followed what was probably a universal norm rather than a peculiarly European one, and one that aligned with local practices.

46 "De coningen van Laijo en Bancala met het gansch lant van Turata ende Padjingh en al wat daar onder hoort, staande den oorlogh tot de Compagnie overgekomen ... te erkennen voor vrije soningen, Heren en landen, daarse niet ter werelt op en hebben noch en houden te pretenderen, de selve ontslaande van alle voorgaande heerschapij en gebied, nu en altoos." November 18, 1667 treaty, art. 19, Corpus Diplomaticum, 2.377.

47 "van de Compagnie en haare bondgenoten volgens reght van oorloge." November 18, 1667 treaty, art. 20, Corpus Diplomaticum, 2.377.

48 "Sullen sijn en blijven als eigen vrij gewonnen landen." November 18, 1667 treaty, art. 20, Corpus Diplomaticum, 2.377.

49 Compare for one Andaya's account of wars and dominion transfers in South Sulawesi, in Andaya, The Heritage of Arung Palakka, chap. 1, "State and Society in South Sulawesi in the $17^{\text {th }}$ Century," 9-45. 


\section{Sanctions against local petty states that had sided against the Company and its allies}

There was also the challenge of how to handle the states that had sided with Makassar against the Company, but which had not actually been conquered during the war. This was the case for Wajo, Boeloe-Boeloe, and Mandar, which were treated together in article 21.

The article started off with a dose of blame and shame, branding the states of Wajo, Boeloe-Boeloe, and Mandar as criminals for having sided against the Company and its allies. ${ }^{\circ}$ As in the cases of other former foes, the sanctions were that their alliances to Makassar were to be cut and transferred to the Company. ${ }^{51}$ Makassar's abandonment of all claims on and ties to these states was further emphasised as valid "from now and henceforth forever, without any exception whatsoever." ${ }^{2}$ The break was supplemented by an explicit noninterference clause that stated that these states "neither directly or indirectly, not now nor ever must supply the Government of Makassar with manpower, weapons, gunpowder, lead, provisions, or advice or actions, whatever it might be called." ${ }_{33}$ So, although the petty states took the shame, the weakening of the power of Makassar was the aim. However, the point to us is the way it was formulated: Once again, the wording is direct and focused and with repetitious language to close any possible loopholes.

\section{Configuring the respective polities into a hegemonic system (articles 23-25)}

Having forged a new system of alliances and distributed rewards to friends and retribution to former foes, it remained to integrate the respective treating parties in Sulawesi and the outer islands into a coherent system, which was done in articles 23-25. Numbers should not deceive however: these three articles

50 "misdadigh aan de Compagnie en hare Bondgenoten." November 18, 1667 treaty, art. 21, Corpus Diplomaticum, 2.377.

51 "verklaart de hooggemelte regeringe (Makassar) te abandonneren end ons daar met te laaten gewerden." November 18, 1667 treaty, art. 21, Corpus Diplomaticum, 2.377.

52 “Nu off oijt nae desen." November 18, 1667 treaty, art. 21, Corpus Diplomaticum, 2.377.

53 "sonder deselve (the Government of Makassar) directelijck off indirectelijck, nu off oijt nae desen te sullen secunderen met volck, wapenenen, krujt, loot, spijse, raad, daet off andersints, hoe het oock genoemt mogte werden." November 18, 1667 treaty, art. 21, Corpus Diplomaticum, 2.377. 
made up the jewel in the hegemonic contractual crown. It was through them that a coherent hierarchical system, with the Company at the summit, was constructed.

\section{Article 23: Reconfirming the Company's political hegemony}

Article 23 started with a confirmation of article 6, in which the privileged position of the Company, to the exclusion of all third parties, was laid down. ${ }^{54}$ It was but a statement of the basic precondition for the Company's new political position in the area, namely its de facto overlordship over Makassar. The rest of article 23 spelled out Makassar's obligations as a vassal to the Company. It was first obliged to help secure the Company's privileged position by committing itself to tracking down and expelling any non-Dutch Europeans who tried to settle down in Makassar, "in case any third party against its wish attempted to settle down, it must refuse and deny this with all its might and power, according to its treaty obligation." ${ }_{55}$ The recognition of the Company's status as overlord also carried the obligation to assist it militarily when called upon to do so, ${ }^{56}$ and as was the case with the outer islands the Makassarese were forbidden to engage in any diplomatic negotiations with any party being at war with the Company. ${ }^{57}$ In short, the vassalage position of Makassar precluded both the means to and opportunity of launching autonomous foreign policy initiatives.

As for the formal explication of Makassar's submission to the Company, it was presented as a derivation of Makassar's obligation to call in defensive assistance from the Company in case of third-party intrusion. When first let out however, it was repeated and reaffirmed as a statement of the general lord-vassal relationship between the two: If the Makassarese were not able to fend off third-party intruders they should call upon the Company for help, by right of

54 "belooft in conformiteit van't seste artikul hare landen voor alle anderen natien gesloten te houden." November 18, 1667 treaty, art. 23, Corpus Diplomaticum, 2.378. 1045

55 "en in cas enige van deselve tegens hunnen danck daar in sich begeerden neder te slaan, deselve met alle vermogen en magt te sullen afweren volgens hare gehoudenisse van desen contract.” November 18 , 1667 treaty, art. 23, Corpus Diplomaticum, 2.378.

"Sullen sij oock gehouden wesen, daartoe geroepen wesende de E. Compagnie te adsisteren met alle vermogen tegen sodanige vijanden als hun hier bij of omtrent Makassar tegen de Compagnie moghten openbaren." November 18, 1667 treaty, art. 23, Corpus Diplomaticum, 2.378.

57 "dat sij in geen onderhandelinge van vreede off andersints treden sullen met enige natie, daar met de Compagnie is in oorlog." November 18, 1667 treaty, art. 23, Corpus Diplomaticum, 2.378. 
its position as Makassar's overlord. ${ }^{8}$ The inscribing of the Company's overlordship over Makassar in November 1667 was thus neat and simple. One does well to notice that the general statement of Makassar's vassal position is derived from a specific obligation. A "Eurocentric" approach would have had it the other way around.

\section{Article 24: Incorporating Makassar's vassalage position into the new local and regional treaty system}

In article 24, Makassar and the other vassal states and allies were incorporated into a system of overarching regional alliance. The article simply stated that the treaty of "lasting peace, friendship and alliance"59 between Makassar and the Company was to be regarded as "also binding" 60 for the kings of Ternate, Tidore, Batjan, and Buton, as well as for the kings of the other states of Sulawesi: Bone, Soppeng, Loeboe, Turate Laijo, and Badjing, "with all their domains and subjects." ${ }^{61}$ The alliance order was also given a prospective twist in that it should be open for "any rulers or princes who would from here on wish to join it." ${ }^{\prime 2}$ Having thus knit the respective contracts into a single unit, it was time for the Dutch to explicate its hierarchical structure.

\section{Article 25: The hierarchy of hegemony}

Article 25 cemented the Company's supreme position in the system of alliance by declaring it the ultimate source of power and authority. In case of conflict between the treating parties, the Company would act as the final institution of peacekeeping and arbitration: "If it be the case that some sort of misunderstanding or conflict between the alliance partners should arise, so must the

\footnotetext{
58 "Ingevalle sij (the Makassarese) daartoe niet vermogens waaren ... als dan de Compagnie als haaren schut- en schermheer tot adsistentie soude versoecken also wij verclaren, deselve Compagnie in dier qualiteit te erkennen." November 18, 1667 treaty, art. 23, Corpus Diplomaticum, 2.378. "duurende vreede, vriend- en bontgenootschap." November 18, 1667 treaty, art. 24, Corpus Diplomaticum, 2.378 .

60 “ook werde begrepen." November 18, 1667 treaty, art. 24, Corpus Diplomaticum, 2.378.

61 "met alle haare landen en onderdanen." November 18, 1667 treaty, art. 24, Corpus Diplomaticum, 2.378. Repeated in the final article: "nevens alle de coningen en prince in dit verbont begrepen." November 18, 1667 treaty, art. 30, Corpus Diplomaticum, 2.380.

62 "soodanige andere landheeren en vorsten als naar desen sullen versoecken mede in dit bontgenootschap te mogen treden." November 18, 1667 treaty, art. 24, Corpus Diplomaticum, 2.378.
} 
involved parties not act or go to war against each other, but present the issue to the Captain of the Hollanders for arbitration." ${ }^{3}$ If on the other hand, the arbitration proved unsuccessful, and one of the parties refused to accommodate, the remaining parties were made collectively responsible for sanctioning the uncompromising party. This collective responsibility was formulated in rather moralistic terms: "But if one of the parties still after arbitration stubbornly refuses to accept and bow to reason, then the other parties should jointly help the grieving party to see the just cause." ${ }^{64}$ The implicit condemnation was thus but a negative complementary of the positive appeal in the preceding paragraph, where the intention of the arbitration was presented as to "eliminate disagreements and to preserve the good brotherhood between the alliance partners." 65

\section{Summing up: The Company as hegemon by treaty}

Sweet words of harmony and collective responsibility should not fool us. The crux of the matter in the political reordering of the November 1667 treaty was that all treaty commitments by all the Company's treaty allies were based on, and bound together by, the Company's position as ultimate "protector and defender." The system was held together by the recognition of the Company as overlord. This hegemonic position acquired its character from the fact that none of the other partners owed any vertical allegiances to each other, aside from being bound together by shared allegiance of loyalty to their overlord, the Company. If this was a brotherhood, it was headed by the Company as Big Brother. Still, it is well worth noticing that this compound was presented as a unity forged by shared interests, although ultimately protected and preserved by the Company.

63 "Off het geviele dat tusschen de bontgenoten ende respective coningen het een off ander misverstant eenige differentie quame te ontstaen, so sullen partijen niet stracx malkanderen daarom eenigh ongemack off oorloge aandoen, maar haar questie de capitain der Hollanders bekent maecken, omme soo het mogelijck is, door bemiddelinge van desselve, de oneeigheden uijt de weg te leggen.” November 18, 1667 treaty, art. 25, Corpus Diplomaticum, 2.378-79.

64 "Maar indien een van de partije naar geen bemiddelinge luijsteren ende hartneckig blijven wilde, sonder sich na de rede te voegen, als dan sullen de gemeene bontgenoten de andere naar vereijsch ende regt van saken te hulpe komen." November 18, 1667 treaty, art. 25, Corpus Diplomaticum, 2.379.

65 "de oneenigheden uijt de weg te leggen ende goede broederschap te conserveren." November 18, 1667 treaty, art. 25, Corpus Diplomaticum, 2.379. 


\section{The language of Big Brother}

In the November 1667 treaty, the mode of formulation of the political regulations, even more so than in the 1660 treaty, reveals an almost obsessive pursuit to fill in possible gaps and block loopholes for Makassarese evasion by being as concrete and specific as possible. Prior experience and lingering suspicions that Hasanuddin would try to take advantage of loopholes and bend the treaty to his advantage must have lain behind this. Lack of trust also goes to explain the endless repetitions of pre-emptive formulations such as "any," "without exception," "whosoever," "under what pretext whatsoever," and so on, at the expense of European legal jargon in the November 1667 treaty, as had been the case in the one of August 1660. That is easy to explain: Both were contracts engineered for low expectations to Makassar as a partner after 1655. But, as we have seen, the High Government also had other means than the rational, down-to-earth treaty text of securing bonds of loyalty. The treaty with Tello of March 1668 was exclusively based on such means.

\section{Section 5: The 1668 treaty with Tello: Paternalism as the cement of loyalty}

The March 9-31, 1668 treaty between the Company and Tello was a treaty between the Company and the raja of Tello and Karaeng Linques, who had originally sided with Makassar but were absent from the signing of the November 1667 treaty. ${ }^{66}$ The March 1668 treaty was meant to secure their loyalty to the former. In this regard, it completed the hegemonic regime laid down in the November 1667 treaty. The crucial and in fact only rationale of the March 1668 treaty was thus the explication of the unqualified commitment of the raja of Tello and Karaeng Linques to the 1667 treaty and thus the declaration of their total submission to the Company. What is of interest to us regarding the March 1668 treaty is the form that was applied to achieve this. For, while the November 1667 treaty was certainly not free of paternalistic implications, the public abject submission to the Company was the essence of the March 1668 treaty. 
The treaty was presented in the form of a declaration by the raja of Tello in which he explained his decision to declare himself a friend and ally of the Company by reasons of the "loyalty and fatherly care that the Company had always displayed toward its allies." ${ }^{67}$ The praise of "fatherly care and protection" was further elaborated. The king of Tello put himself and his heirs under the protection of the Company to be recognised as "true friends and allies of the Company, which would take care of their needs like a father" ${ }^{\prime \prime 8}$ because the Company would protect Tello "from any wrongdoings or injustice that might befall it." ${ }^{69}$ The king also declared that he had arrived at his decision to offer himself as friend and ally "by advice from and consultations with his overlords, brothers and subjects." ${ }^{\circ}$ In other words, the act of submission was unanimous and uncontested. The submission to the Company was further on presented as comprehensive; the king had decided to "commit himself, his whole realm and all his jurisdictions to the Company." ${ }^{71}$ The bond between Tello and the Company was also presented as being irrevocable, binding not only on the king himself but on his heirs and successors, as well. ${ }^{72}$

\section{Hegemony by patrimony}

The way in which the March 1668 treaty was framed and phrased in paternalistic terms marked it as being distinctively from that of November 1667. But, the March 1668 treaty was after all not a treaty of technical regulations, but a demonstrative act of submission. When the lord-vassal relation was expressed in local idiom by hierarchical family relations, as is the case here, it may well illustrate the Company's willingness to accept or even prefer the local idiom to specified and numerated articles in the treaty so long as it did not jeopardise

67 "mij erinnerende de getrouheyjt en vaderlijcke zorge, waar met de de Compagnie doorgaans en altoos is angedaen over hare verbonde vrunden en bondgenooten." March 9-31, 1668 treaty, Corpus Diplomaticum, 2.381.

68 "waare vrunden en verwanten van de Compagnie, die se hout en neemt in haare vaderlijcke bewaringe." March 9-31, 1668 treaty, Corpus Diplomaticum, 2.381.

69 "opdat ons van niemande ter werelt eenigh leet of onreght mogte overcomen." March 9-31, 1668 treaty, Corpus Diplomaticum, 2.381 .

70 "naar ingenomen advijs van mijne lantsheer en broeders en onderdanen, te raade te zijn gewerden." March 9-31, 1668 treaty, Corpus Diplomaticum, 2.381.

71 "mij en de mijne, oock nevens dien mijn gantsche rijcke en jurisdictie, noch nader en int bijsonder met deselve Compagnie te verbinden." March 9-31, 1668 treaty, Corpus Diplomaticum, 2.381.

72 "en tevens te versoecken dat ik niet alleen in hare bescherminge particulierlijck aengenomen, neen maar oock mijne kinderen." March 9-31, 1668 treaty, Corpus Diplomaticum, 2.381. 
more specific agreements formulated elsewhere. If so, this only goes to demonstrate that the Company drew on a variety of modes for multiple needs in the overseas context. Which to choose was determined by an assessment of the local overseas situation.

\section{Section conclusion: The 1667 and 1668 treaties of hegemony}

The November 1667 treaty was titled an amendment ${ }^{73}$ to the 1660 treaty, but it was more of a political revolution as far as changes in regional power relations were concerned. The 1667 "amendments" restructured the entire bilateral interaction regime between Makassar and the Company by excluding or restricting Makassar's bilateral interactions with Europeans and non-Europeans in the archipelago. It restructured the political geography of Sulawesi by cutting political bonds that had made Makassar a political hegemon and redirecting these bonds of allegiance to the Company. The treaty mode and means by which these transformations were secured were far from exports of European style legal parlance. They represented adapted constructions to meet practical challenges of given overseas context and situations.

\section{Chapter conclusion}

My analysis of the respective treaty texts treated in chapters 7 and 8 shows that the formulations and content of the post 1655 treaties were more the product of adaptation to assessed needs on site than the transfer of legal ideas from Europe.

The treaty making was not based on a single model. The treaty- record with Makassar between 1637 and 1668 demonstrates that there were a variety of modes in the Company's toolbox of overseas treaties, too. Which mode to apply was determined by the specific needs it was supposed to serve, and the perceived options and constrictions in a given situation or context.

Above all, treaty making was a dynamic learning process. The logic went as follows: Appreciation of context was formed by experience. As experience was accumulated, so the dynamics of treaty making accelerated. The motor in these

73 "Naarder artijculen ende poincten." November 18, 1667 treaty, Preamble, Corpus Diplomaticum, 2.371. 
dynamics lay in the processing of overseas experience, not in the implementation of or deduction from legal principles brought from overseas.

Evidence from the treaties reveals a lot of "engineering" in terms of working out the constituent parts of the machine as well as the structure of the machine itself. Throughout this analysis, I have demonstrated that the design of the machine as well as the fitting of its parts bore a prominent "overseas stamp." That was no coincidence. That was the hallmark of how Company diplomacy came to adapt itself functionally to the particularities of the overseas context. One such change is particularly noteworthy. After the 1655 treaty proved counterproductive, the High Government turned to a much more encompassing and detailed mode of treaty. This occurred in two stages; first by a much more detailed and regulated interaction system in the August 1660 treaty, and then as an even more politically integrated system of hegemony in November 1667. Contrary to Andaya's propositions, I have demonstrated that these changes did not represent a return to European models, but quite the contrary, an even closer orientation towards the overseas context.

As for Speelman's diplomatic performance during the 1667 campaign, some specific achievements should also be noted. First of all he managed to keep the alliance with Arung Palakka and the Bugis intact, which was vital in bringing about the military victory. Second, with the Bongaya Treaty of 1667 , he managed to construct a political order that not only pacified Makassar, but also integrated Makassar and sultanates in the Moluccas into the Company's hegemonic order. Possibly one of greatest of Speelman's achievements in this connection was his successful arbitration and reconciliation between the former enemies, the sultans of Ternate and Tidore, manifested in the treaties concluded between them and the Company on March 29 and 30, respectively. ${ }^{74}$ 



\section{9}

\section{The Pragmatic, Empirical Model of Overseas Diplomacy in Cornelis Speelman's Notitie}

\section{Section 1: Chapter introduction}

The challenge of preserving the Company's hegemony by diplomacy

The Company tactics to stabilise their power in Ambon was to cut local bonds, establish equality between the local units and forge new ties with each single local unit to itself as overlord. To establish consensus, the tactic was to play on the elite by giving the village heads a position in the administration, and make them swear an oath to the Company. ${ }^{1}$ The Company's hold of power posed challenges comparable to those in Ambon, as well as similar, but also somewhat different solutions.

The preservation of the Company's hegemonic regime basically rested on keeping the Makassarese at bay; but it depended particularly on the successful preservation of the alliance with the Bugis. There is no evidence to support the proposition that Cornelis Speelman ever believed that these challenges could be satisfactorily solved by treaty alone. The two extra supporting pillars of the Company's hegemonic regime were its military presence in Sulawesi, and the pre-emptive use of diplomacy to preserve the loyalty of both original allies and former foes.

$1 \quad$ Knaap 2004, 41. 
For both the original allies and those who had recently become friends, the diplomatic challenge lay in continuing to cultivate good relations while at the same being on the alert for any signs of a slackening of commitment or independent policy-scheming. Thus, in both cases, preserving the Company's political hegemony depended on diplomacy based on good intelligence on political intrigues locally. The topic of this chapter is Speelman's reflections on and advice about the challenges of the Company's hegemony, and the role of diplomacy in maintaining it, as put forth in his report to the High Government on the completion of his mission in $1669,{ }^{2}$ which was praised by Noorduyn as going "deep into the history of the Buginese and Makassarese." 3 Before I start to analyse it I shall start by giving a brief overview of Speelman's diplomatic career in the Company to put his performance in and reflections on Makassar into perspective.

\section{Section 2: Cornelis Speelman, a brief diplomatic- military biography}

Cornelis Speelman left the Republic for Batavia in 1645 at the age of 17. Until his death in Batavia on January 11, 1684, he held a variety of positions in the Company's administration. ${ }^{4} \mathrm{He}$ started out as assistant and climbed upwards to become "boekhouder" (bookkeeper) in 1648, "onderkoopman" (junior merchant) in 1649, before he was promoted to "koopman" in 1652. On December 28,1655 , he was made "boekhouder-generaal," and on March 24, 1671, he was appointed ordinary member of the Council of the Indies. With Maetsuyker's death in January 1678, and Rijcklof van Goen's succession as governor-general,

2 "Notitie dienende voor eenen corten tijt en tot nader last van de Hooge Reeeringe op Batavia, tot naarrigtinge van den Onderkoopman Jan van Oppijnen, bij provisie gestelt tot Opperhooft en Commandant in 't Casteel Rotterdam, op Makassar, en van den Capitain Jan Fransz.: als hoofd over de Militie, mitsgaders die van den Raadt." VOC 1276 OB, Inkomen Briefboek Makassar 1671, fols. 684-1007. (Hereafter Notitie.) I have had immense help by comparing the original source with the typed manuscript undertaken by W. Ph. Coolhaas and H. J. de Graaf in 1949-50, now at the KITLV (Nr. H 802). For a brief introduction to the Notitie, see J. Noorduyn, De handelsrelaties van het Makassaarse rijk volgens de notitie van Cornelis Speelman uit 1670 (Amsterdam: Verloren, 1983), $99 \mathrm{ff}$.

3 Noorduyn, 1955, 6.

4 The chronology to Speelman's administrative career in Batava is based on P. C. Molhuysen, P. J. Blok, and L. Knappert, eds., Nieuw Nederlandsch Biografisch Woordenboek, vol. 5 (Leiden: A. W. Sijthoffs, 1921), 1254-57. The section on Speelman's military-diplomatic career outside Batavia is is based largely on F. W. Stapel, Cornelis Janszoon Speelman ('s-Gravenhage: Martinus Nijhoff, 1936). 
Speelman was made director-general. He ultimately took over as governorgeneral on November 25, 1681, in which position he served until his death. Speelman was to receive criticism for sloppiness in performing his duties as governor-general, so that although formally his appointment marked the top of his career, his performance in the position did not. ${ }^{5}$

Still, whatever the evaluation of Speelman's performance within the Company hierarchy in Batavia was, of greater relevance here is his diplomatic and military career and performance outside the colonial headquarters. Speelman's diplomatic experience started with his participation in Councillor of the Indies Joan Cunaeus' diplomatic mission to Persia, September 15, 1651 to November 12, 1652. In his capacity as secretary, he wrote the whole report on the mission, though he is not reckoned to have had any influence over the actual proceedings due to his age, and inexperience. ${ }^{6}$

Stapel credits him for registering events with an observant eye, often recording local modes of negotiating with humorous comments. ${ }^{7}$ All in all, Speelman must have performed well, as after the mission's return to Batavia he was promoted from onderkoopman to koopman on Cunaeus's recommendation. ${ }^{8}$ In this period, and as a glimpse of what was to be his later emphasis on getting to know the ways of the local people, it is evident that at least as early as 1655 he had acquired a working knowledge of Malay. ${ }^{9}$

From July 2, 1663 to October 18, 1665, Speelman served as the Company's governor in Coromandel, one of the more important Company positions outside Batavia. Considering the number of different parties the Company had to deal with there-not just local princes and power holders, but also rival Portuguese, English, French, and Danish merchants-the position demanded particular insight and competence. ${ }^{10}$ Adding to Speelman's challenge during his period in Coromandel was that by January 1665 news of the Second AngloDutch War between the Republic and England had reached Asia. ${ }^{11}$ Symptomatic

For points of charges brought against Speelman after his death for his ill conduct in office, see Stapel, Cornelis Janszoon Speelman, 153. Naar Perzië in 1651-1652 door Cornelis Speelman, (Amsterdam: Johannes Müller, 1908), Inleiding, lxx.

7 Stapel, Cornelis Janszoon Speelman, 5-6.

8 Ibid. 7.

9 Ibid. 8.

10 Ibid. 12.

11 Ibid. 21. 
of Speelman's direct mode of facing challenges was that he asked permission to attack Fort George. Although he received permission to do so, he was asked to return to Batavia to answer to allegations of private trade before he could begin the campaign. ${ }^{12}$

Suspicions about Speelman having taken part in private trade had arisen among the Heeren XVII already in 1662 because of letters sent by Speelman in August that year, in which it was clear that he wanted a diamond stone, originally meant as a present for his wife, cut and sold in the Republic. ${ }^{13}$ We need not go further into details, except to note that Speelman was barred from the Company's service for fifteen months and fined 3000 florins. ${ }^{14}$

The private trade allegations are included here for two reasons. First, Speelman's determination to fight the allegations-as exemplified by his letters written in self-defence (one in January 1664 and two in December 1665) ) $^{15}$ gives us an idea of his tenacity. Second, because the affront Speelman must have felt over the accusations may well have been a motivating factor in his pursuit of personal glory in the Makassar campaign. Andaya, for one, seems to regard this as decisive in Speelman's motivation. "It was perhaps Speelman's desire to vindicate his name," he writes, "which led him to 'reinterpret' his instructions and decide to launch an all-out war against Goa. If glory were to be gained, it had to be on this mission."16 Although Andaya's point is plausible, it should be remarked that nothing in Speelman's behaviour during the Makassar campaign is contradicted by his behaviour prior to it.

As Speelman's exploits during the Makassar and eastern quarters campaign is covered elsewhere, I shall only address it briefly here. When the High Government decided to declare war on Makassar on October 5, 1666, Johan Van Dam, the leader of the 1660 campaign was initially offered the command, but when he declined in favour of returning home, the position was offered to Speelman. ${ }^{17}$ It is noteworthy that this offer was made when only nine of Speelman's fifteen months of suspension had passed. ${ }^{18}$ It seems reasonable to take this as an indication of the High Government's trust in him.

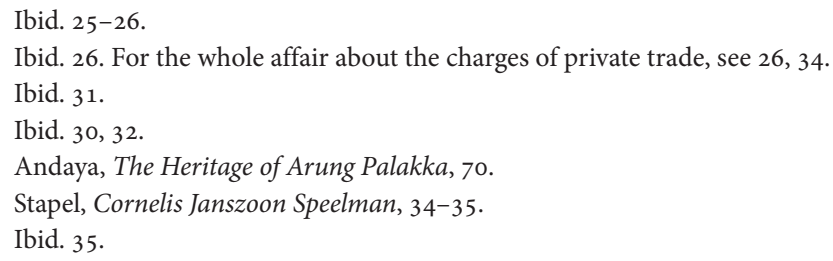




\section{The Java Campaign}

Speelman's next major campaign as commander was in central and eastern Java. In the middle of the 1670 s, a state of unrest and rebellion had arisen there. It started as a rebellion against the susuhunan of Mataram, Amangkurat I, by Trunajaya, the prince of Madura, but in 1675 he was joined in an alliance by Makassarese pirates who had originally sought refuge in Banten after the fall of Makassar, but later emigrated to and settled in the eastern hook of Java. ${ }^{19}$

When the High Government received news that the Makassarese pirates had conquered Surabaya and Grisse, and had handed over both to Trunajaya, the decision was made to fight the Makassarese pirates, but not Trunajaya. After a couple of not too successful raids against the Makassarese pirates, and when the High Government received a request by the susuhunan to lend him support against the Madurese (made in a letter of December 2, 1667, from his governor in Japara), it was decided on December 5 , in an extraordinary session of the Council of the Indies to intervene on the side of Amangkurat I against the Madurese, as well. ${ }^{20}$ Speelman offered himself for the position of command, and was chosen to lead the expedition. He sailed from Batavia with his fleet for the north coast of Java on December 30, 1676. ${ }^{21}$ He would not return to Batavia until April $1678 .{ }^{22}$

During his campaign in central and eastern Java, Speelman concluded five treaties on behalf of the Company with representatives of or with the ruler of Mataram in person. The first was with the susuhunan's governor in Japara, February 28, $1677,{ }^{23}$ the next two with Amangkurat II on October 19 and 20, 1677, respectively, ${ }^{24}$ and another two with Amangkurat II on January 15, 1678, by which the susuhunan renounced his sovereignty over Semarang and surroundings in favour of the Company, and guaranteed monopoly rights for the Company for all the sugar production in the coastal cities. ${ }^{25}$ Taken together, the five contracts secured the Company's superiority over Mataram as well as its commercial monopoly rights. Although political stability was not achieved

\footnotetext{
19 Ibid. $84-85$.

20 Ibid. $85-86$.

21 Ibid. 88.

22 Ibid. 115.

23 Ibid. 90.

24 Ibid. 106. Amangkurat had succeeded his father in July 1677; M. C. Ricklefs, A History of Modern Indonesia since 1300, 2nd ed. (London: MacMillan, 1993), 75.

25 Stapel, Cornelis Janszoon Speelman, 114.
} 
across all of Java before the treaty of Giyanti in $1755,{ }^{26}$ by 1678 , Speelman still had obtained more than the High Government initially had hoped for, or even wanted. $^{27}$

How did Speelman do it? First there was determination and persistence. Already at the initial discussion over the objectives of the Java mission in Batavia, Speelman had put forward the idea that one should not miss the opportunity to see if one could extract monopoly concessions from the susuhunan now that he was in dire need of assistance. The High Government opposed this position. ${ }^{28}$ All the same, already the February 28, 1677 treaty accorded the Company regulation of its eastern border in the Company's favour, securing freedom from tolls and harbour taxes, and gave it the right to build lodges wherever needed, as well as other favours. ${ }^{29}$ Similar privileges were granted in the October 19 and 20 contracts. ${ }^{30}$

While Speelman was dealt a strong hand by the susuhunan's desperate need for assistance, context alone cannot explain his success. Determination and persistence is one part of the answer, but personal charisma must have also played a part. Speelman had, after all, built himself quite a reputation during his exploits before the Java campaign. For one, he was the conqueror of Makassar, and in general, Speelman's fame and high standing among Asian rulers was exceptional. ${ }^{31}$ That Amangkurat commanded all Mataramese to obey Speelman's orders ${ }^{32}$ may have been indicative of this standing. Speelman's insistence on getting to know local conditions must also have played a vital role in his ability to handle local affairs. His Memorie on Java testified to the fact that he had made no exception to the rule of acquiring local knowledge regarding Java and Mataram. ${ }^{33}$

After his return to Batavia and his appointment as director- general after the Java campaign, Speelman increasingly came into the foreground in public life, and his esteem among local rulers continued to rise. Tellingly, letters from local power holders to the governor-general were increasingly addressed to

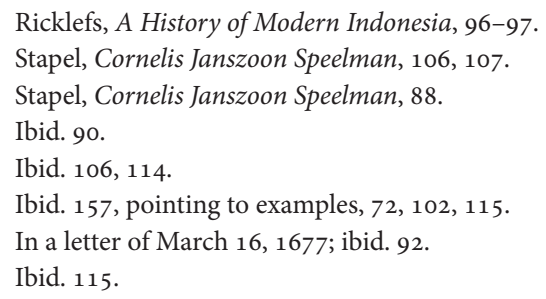


Speelman as well, and even to Speelman alone. ${ }^{34}$ Replies from the High Government increasingly came to be signed by the director-general in addition to the governor-general and members of the Council. ${ }^{35}$

Although Speelman in his period as governor-general, as already mentioned, came to be criticised, he still earned one final success regarding the Company's relations with local Asian powers in this period, namely the pacification of Batavia's neighbour to its west, the trading sultanate of Banten.

\section{The conquest of Banten}

The port-state of Banten was situated on the north-western hook of Java, and comprised also parts of Lampung in southern Sumatra. ${ }^{36}$ Its relationship with the Company, apart from being Batavia’s territorial neighbour to the west, was comparable to and ran in important ways parallel to the development of the Company's relations with Makassar. If one substitutes pepper for nutmeg and cloves, and the English for the Portuguese, we have a similar conflict over trade monopolies and interference of non-Company European rivals that made up the basic conflict with Makassar. Even cycles of negotiations, war, and treaty between Banten and the Company to a certain extent paralleled those between the Company and Makassar. Thus, after a period of conflict in 1636, a truce was made between the Company and Banten that later was confirmed in a treaty in 1639 that in many respects was equivalent to the one concluded with Makassar two years before.

After another period of deteriorating relations after 1639, an agreement for a ten-year peace was made in 1645; but as Banten supported Makassar, a cooler climate again set in. Their rapport worsened when the starkly anti-Company Sultan Ageng came to power in 1651, and tensions heightened as the ten-year truce agreed in 1645 neared its term. Open hostilities started again in 1655, and after intermittent negotiations in 1657 and 1658, ended with a new treaty in 1659 . This is roughly the same period of war and treaty negotiations with Makassar between 1654 and 1660. A short while after the 1659 treaty, relations deteriorated again until Sultan Ageng declared war on the Company

\footnotetext{
34 Ibid. 120.

35 Ibid. 121.

36 The general information on Banten is taken from Guillot, Ambary, and Dumarçay, The Sultanate of Banten.
} 
at the end of April 1680. ${ }^{37}$ To understand the ensuing chain of events up to the peace treaty of April 17, 1684, one has to look at internal conditions and events in Banten from 1680 to 1682 and how the Company reacted to them.

Inside Banten, there was a conflict at the outset between Sultan Ageng and his younger son, Purbaya, on the one side, and his elder son, prince Haji, ${ }^{38}$ on the other. The conflict was caused by Haji's jealousy over being side-lined in favour of his younger brother, but was also caused by differences over policy towards the Company. Haji showed a more accommodating approach than his father and brother. On May 1, 1682, there was a palace revolution in Banten in which Haji ousted his father from power and immediately sent envoys to Batavia to negotiate for peace. ${ }^{39}$ The Bantenese envoys and their entourage reached the roadstead of Batavia on May 8 .

\section{Preliminary negotiations: The issue of letters of delegation}

Negotiations between Bantenese envoys and Speelman and Johannes Camphuis, who were chosen for the task, took place with preliminary hearings about the arrangements and procedures from May 10 to the beginning of June. It is clear from the transcripts of the talks that the Company's aim was to lead Haji's negotiators into a treaty of alliance that would stand up to any formal criticism from rival Europeans, especially the English. Symptomatic of that purpose is Speelman's insistence that the two Bantenese envoys, Sadana and Astradjadja, be provided with a valid letter of delegation of powers from Haji. The discussion of that issue took place on the first day of negotiations proper, May $17 .{ }^{40}$ It is characteristic of Speelman's persuasive mode of negotiating, which combined a paternalistic reproach with a forthcoming attitude. It is worth looking at in some detail.

Speelman opened the session by asking whether the Bantenese envoys had written authorisation empowering them to conclude a treaty ${ }^{41}$ and substantia-

37 The chronology is based on Stapel, Geschiedenis van Nederlandsch Indië, 239, 261, 277, 287, 350-53, and 413-23.

38 Named so after his pilgrimage to Mekka in 1674, Stapel, Cornelis Janszoon Speelman, 132.

39 Ibid. 132-33.

40 The negotiation session is recorded in DRB May 17, 1680, 249-51.

41 "met een credentiebrief waeren voorsien met qualificatie omme met ons in alles te mogen tracteren." DRB May 17, 249. 
ted his request by a reference to the fact that "such was the habit with the Dutch and other nations." 42

Sadana, who was the only one of the two Bantenese ambassadors to speak during the negotiations, replied by saying that the letter from Haji that they had brought on their arrival May 8 was meant to serve this purpose, ${ }^{43}$ and added that according to their custom it should suffice well enough for the purpose. ${ }^{44}$ To this Speelman acidly pointed out that Hajis May 8 letter may well be considered to serve the function of a letter of delegation to the Bantenese, but it did not meet the standards adhered to by the Company. It would have been better if the actual delegation of powers had been explicitly stated. ${ }^{45}$ Rather patronizingly, he repeated that "for the sake of their own convenience in handling their mission, it would have been better still if they had been furnished with a letter clearly expressing their powers as delegated from both the sultan himself and all his nobles." ${ }^{6}$

Speelman went on to phrase his demand for an explicit and specific letter of delegation as an ultimatum: "with no clear credentials, or assurance of delegated powers on behalf of the sultan, all the negotiations might in the end prove to be of no avail and useless." ${ }^{47}$ In other words, if a confirmation by Haji that his two envoys were empowered to negotiate on his behalf was not produced, there would be no negotiations at all. Sadana then had to give in, replying that it would have been better if they had brought such a letter with them." ${ }^{8}$ Sadana offered to return to Banten to get a proper letter of delegation from the sultan, to which Speelman replied that Sadana's rank were credentials enough. Although there was no need for a person of such high rank to go, he advised the Bantenese to instead send someone of lower rank from their entourage. ${ }^{49}$

\footnotetext{
42 "Gelyck onder ons en andere volckeren waere." DRB May 17, 249.

43 "in plaets van dien was dienende." DRB May 17, 249.

44 "na haer wyse genoegsam goet en valiede." DRB May 17, 249.

45 "dat sulx soo waere, maer dat het niet quat waere sulcx expresser by geschrift ware verclaert." $D R B$ May $17,249$.

46 "en oversulcx, toot haar gesantens eygen gerustheyt ontlastinge niet beter soude wesen dat zy sich van den volcomen credentie off volmagt des Conincx en alle de ryxgrooten quamen te voorsien." DRB May 17, 249.

47 "sonder hun volle credentie off vollmagt de conferentien en onderhandelingen wederseyts maar voor nodeloos en onnut zouyden wesen te agten." DRB May 17, 249.

48 "Waarop zy repliceerde sulx mede wel te connen begrypen, dat een volcomen credentiebrieff ...voor haarzelver beter en geruster waere." DRB May 17, 249.

DRB May 17, 250.
} 
So, at the end of what one must regard as a rather humiliating instruction in the proper mode of conducting diplomacy by Speelman, there was also a sugaring of the bitter pill by acknowledging Sadana's rank and status.

One should not mistake Speelman's insistence on proper credentials for dogmatic formalism. There was a real issue involved, but it did not primarily concern the Banten-Batavia axis. It primarily concerned the VOC-EIC axis, and more broadly, relations between the Company and its European rivals. The motive for and intent in obtaining a formal watertight letter of authorisation was to ensure that any agreement between Haji and the Company could withstand challenges to the negotiations' legitimacy from the Company's rivals. Thus, the agreement had to be made "by the book," which required that the Bantenese negotiators be properly empowered. Paradoxically, this issue was but another example of how the context of local interactions imprinted on the Company's mode of approach, although in this case it had the appearance of procedural dogmatism.

In the end, nothing binding came out of the negotiations in Batavia, and the ensuing negotiations in Banten also ended inconclusively because the counterproposals made by the Bantenese were unacceptable to the Company. All the same, relations between Banten and Batavia remained peaceful through $1681 .{ }^{50}$

Inside Banten, however, a civil war erupted in the beginning of 1682, as Sultan Ageng supported by the English and other Europeans residing in Banten sought to regain his power from Haji. As the rebels gained increasing support in the beginning of March, and Haji became isolated in his residence in Banten, he sent a letter to the Company asking for assistance.

Speelman convened the Council on March 1, when a decision was made to assist Haji in order not to miss "this golden opportunity." At the same time, it was also decided that the Company should initially offer to arbitrate between Ageng and Haji. As Ageng did not even respond to the Company's offer, the Company engaged itself militarily on Hajis side. ${ }^{51}$ We need not go into details of the Banten campaign here, except to state that in the end it was a success for the Company, and resulted in the treaty between the Company and Banten of April 17, 1684 that made Banten a vassal state of the Company in all but name.

\footnotetext{
50 Stapel, Cornelis Janszoon Speelman, 133.

51 Ibid. 134-35.
} 
By the time of the signing of this treaty, Speelman had already died, but surmising that he may have had some influence over the outcome, and because parts of the treaty illustrate another aspect of the Company's diplomatic repertoire than we saw in the handling of the delegation of power issue, I shall offer some comments on it.

\section{The 1684 contract}

The April 17-28, 1684, treaty between Banten and the Company ${ }^{52}$ consisted of ten articles and two amendments: a statement by the sultan about the treaty, called an acte van obligatoir (declaration of obligations) and a declaration of remission of debts owed by the Sultan to the Company by the governor-general and the Council of the Indies called an acte van remissie. ${ }^{53}$

The two amendments to the 1684 treaty laid down a transaction in which the acte van remissie gave the Company a monopoly on the purchase of pepper and the sale of Indian cloth in Banten, and in return relinquished its claim on Haji for war costs. The acte van obligatoir also stated the background for Haji's debt of gratitude to the Company for its assistance to him during the civil war. Additionally, in the way it narrated the story of the relationship between Haji and the Company, it sought to make the arrangement between the Company and Haji into a solid patrimonial relationship of Company generosity and altruism reciprocated by gratitude and loyalty from Haji. This also made the relationship impenetrable and immunized the Company against accusations of interference by outsiders. This illustrates a constructivist aspect of treaty making very well, and I shall analyse it in some detail.

The main part of the text in Sultan Haji's acte van obligatoir gives a chronological account of the events from Ageng's abdication in May 1680 to the Dutch intervention in 1682. The background for Haji's precarious position, his letters asking support from Batavia, the Dutch offer of assistance linked to the offer of arbitration and Ageng's rejection of it, and Hajis rescue by the Company, are all recorded true to the basic historical facts. All the same, these facts are described in a manner that underscores the patrimonial bonds between Haji and the Company.

52 In Corpus Diplomaticum, 3.336-51.

53 Corpus Diplomaticum, 3.342-46 and 346-47, respectively. 


\section{The Company as the "Good guy"}

Being narrated in the firstperson plural by the sultan, the prominent theme in the acte obligatoir is his recognition of his bond of gratitude to the Company. The focus is placed on the Company's assistance to him, which has been "rendered so loyally and proved to be so important." ${ }^{54}$ The Company is further praised for having "dedicated itself fully, and spared neither their empathy, nor money nor men" ${ }^{55}$ in their support for the sultan's cause.

\section{The other foreigners in general and the English in particular as the "Bad guys"}

The loyal dedication of the Dutch must be understood as all the more praiseworthy when contrasted to the devious conduct of the other European nations at Banten, who had allied themselves with and supported the rebels with arms as well as with money from the beginning of the rebellion against Haji. ${ }^{56}$ The Dutch thus by both explication and implication stand out as Haji's only true and committed friends. When Haji was still sultan in 1684, it was thanks to the Dutch intervention. Haji's moral obligation to the Company should thus be "obvious to the whole wide world."

\section{Tokens of gratitude}

Given Haji's bond of gratitude to the Company for its efforts in support of his cause and the services rendered to him, the privileges given to the Company are to be regarded as no more than tokens of his obligations to the Company. The commercial privileges are depicted as an offer of compensation made by Haji and not as demands from the Company. They are, in fact, presented as Haji's initial offers. The opening paragraph of the acte obligatoir states that Haji had decided "to approach the Company not only with the promise to

\footnotetext{
54 "de hulpe, die soo getrouwelijk en soo vrughtbaar bewesen is." Corpus Diplomaticum, 3.342.

55 "niet gespaard haar sorg, onkosten en volk om mijn rebellige onderdanen te dwingen en ons te herstellen." Corpus Diplomaticum, 3.344.

56 "Van den beginne des vyandschap af den vyand geholpen met raad en met daad en met wapenen en oorlogengereetschap en met geld." Corpus Diplomaticum, 3.343.

57 "opdat onse schuldige beleydenis en dankbarheyt openbaar werde voor de gantsge wereld." Corpus Diplomaticum, $3 \cdot 344$.
} 
compensate [it] for the war costs, but also to accord an exclusive privilege of all trade on Banten to the Company." 58 Those were Haji's terms or offer if the Dutch would help him keep the throne and establish peace and order in his realm. ${ }^{59}$

It is further noted that the Company is the generous party. Haji's offer of compensation is stated to be less than a fair return for the services rendered to him; in fact, the Company could fairly have demanded more in return for its services or benevolence. ${ }^{60}$ An appeal to legal legitimacy is forsaken for the benefit of motives of altruism, although implicitly mixed with promises of material gain: "Realising the sultan's precarious situation, the governor-general and Council were moved into action by the sultan's promises and their compassion." ${ }^{1}$ The noble aspect of the Company's motives is emphasised.

The Dutch condition that before they could dedicate themselves militarily to Haji's cause, they must first establish whether there were any grounds for arbitration with Ageng, fits into this configuration of benevolence and altruism. The offer of arbitration must be understood as an indication that the Company was dragged into the conflict against its will. In this scenario, the fact that Ageng ignored the arbitration offer is used to present a contrast between a moderate, peace-seeking Company and a hardened and uncompromising Ageng abetted by his European supporters. The Council had decided first to see if there was any possibility of Ageng and the rebels agreeing to a peace, ${ }^{62}$ but the latter "were neither willing to negotiate nor to enter a truce, nor hear any talk of peace, encouraged and supported as they were by other European residents." ${ }^{63}$ In other words, because Ageng was intent on war with Haji and

58 "te versoeken de hulp en bystand der Comp.ie, op conditie, dat wy niet en allen souden voldoen de penningen en oncosten, welcke door de Comp.ie dartoe verspielt soude moeten werden maar daarenboven ook haar te geven octroy van den gatschen handel, met uytsluytinge van alle andre natiën of personen." Corpus Diplomaticum, 3.342.

59 "Alles met conditie, dat wij maaar alleen souden blyven sultan van Bantam, met rust en vrede." Corpus Diplomaticum, 3.342.

60 "reeds merder vereyst werd tot vergeldinge van haer dienst (ofte weldaad)." Corpus Diplomaticum, $3 \cdot 344$.

61 "Wanneer den Gouverneur- Generaal en de Raden van India ... onse uyterste nood sagen, soo sijn sy door onse beloften, en haar medelyden bewogen geworden." Corpus Diplomaticum, 3.342-43.

62 "dat sy eerst souden ondersoken of den sultan Agon en zijn wederspannig volk niet in der minne te vreede konde gestelt werden." Corpus Diplomaticum, $3 \cdot 343$.

63 "maar haar rebellie en hertnekkigheyd ... was soo vermeerdert en toegenoemen, dat sij weygerden aaan te horen eenige redenen of versoek tot stilstant van wapenen of tot vrede gevoed en ondersteunt door de Frangise residenten." Corpus Diplomaticum, 3.343. 
the Europeans residing in Banten conspired with him and encouraged him, the Company was driven to intervene to support the lawful ruler and re-establish law and order.

The Company's accommodationist approach manifested itself even after victory. Although Haji would have liked to see the Europeans who sided with Ageng punished more severely, at the Company's urging he agreed merely to expel them from the realm. ${ }^{64}$

So, not only were the Dutch content to see their European rivals disappear from Banten, events had played into their hands to present it a consequence of their rivals' own doing in a course of events that the Dutch themselves had done nothing to instigate. On the contrary, they had acted as go-betweens to "soften" the attitude of the sultan, to "rescue" their fellow Europeans from a more forceful revenge.

For all the explicit and implicit praise of the Company in the sultan's acte obligatoir, the Company's actions between 1680 and 1682 had another, much more narrowly defined dimension of power politics about it. But, the configuration of the Company's altruism and Bantenese gratitude and obligation had a function in power politics, too. They went to provide legitimacy to both the Company's intervention as well as its post-war arrangement with Banten.

Despite their difference in form, the patrimonial altruism in the depiction of Company-Banten relations described in the acte obligatoir and the seemingly procedural dogmatism in Speelman's stand in the May 17, 1680, negotiations in Batavia were both manifestations of the wide spectrum of pragmatic treaty configurations in the Company's diplomatic repertoire at the time. A close reading of the acte van remissie makes it clear that the altruism was pragmatic and not idealistic, because it was stated as a condition of the remission of debt that it could be revoked at any time should the Bantenes meet their contractual obligations. ${ }^{65}$ Poorly concealed under the Company's self-praise was, in other words, its insistence on its rights by treaty, and implicitly its will to enforce them if necessary.

As we now move on to the more specific topic of Speelman's advice on the diplomatic approach towards Makassar, my proposition is that in that case too Speelman reveals a similar broad-spectered pragmatism.

\footnotetext{
64 Corpus Diplomaticum, $3 \cdot 344$.

65 ende so wij ter contrarie in het gebruyk en geniten van het meergenoemde octroy warden verhindert... om deselve schult ten allen tijden te mogen eysgen en ontfangen, Ibid. 347
} 


\section{Section 3: Analysis, the Notitie On the Notitie as a source for Speelman's thinking about overseas diplomacy}

After having secured the Company's power in Makassar, Speelman left for Batavia in October 1669. Shortly before that, he had begun writing his instructions and advice to assistant merchant Jan van Opijnen, who had been left in charge in Makassar. During the six-week voyage to Batavia and after his arrival Speelman continued working on the manuscript, until it was finally delivered to the High Government on February 17, 1670. The original manuscript is probably no longer in existence, but the oldest surviving copy runs to 646 folio pages in all. ${ }^{66}$ The analysis below is based on the latter.

The Notitie covers the period from Speelman's arrival in Makassar in November 1666 up to his departure. The text is organised in part chronologically and part topically. Thematically, it can be divided into two parts: Speelman's instructions for the defence and administration of Fort Rotterdam, and a survey of the political geography of South Sulawesi. The latter can in turn be further split into sections devoted to the Company's Bugis allies, the outer islands, and former allies of Makassar in Sulawesi. These three parts concern respectively, local colonial administration, descriptions of and reflections on the Company's allies, and descriptions of the Company's erstwhile enemies during the campaign. A striking feature of Speelman's treatment of his subject is his detailed and at times intimate description of individual power holders regarding both their personal traits and personal and kin relations. Quite apart from the political implications, this bears witness to Speelman's thorough knowledge of local affairs.

In addition to information on local political conditions, he also included observations on topography, flora, fauna, geography, and history. Some of this seems to have been written out of a sheer joy of observation and formulation, but most of it was primarily meant to provide relevant information to the Company's residents in Makassar with tacit and explicit advice about how to act to preserve the Company's position.

66 For the chronology and general introduction to the Notitie, see J. Noorduyn, De handelsrelaties van het Makassaarse rijk volgens de notitie van Cornelis Speelman uit 1670 (Amsterdam: Verloren, 1983), 99-101. 


\section{Propositions}

Beginning with Speelman's reflections and advice on diplomacy in the Notitie, I intend to demonstrate that he applied a consistent casuistic approach to diplomatic interaction with local power holders, whether they were friends or foes. He stressed the need to obtain as precise information of local conditions and circumstances as possible, in the evident belief that diplomacy had to be based on a knowledge of and willingness to adapt to local conditions. Conversely, formal legal considerations receive little if any consideration. I shall term this approach "empirical, pragmatic diplomacy." By its pragmatic approach, this also represented a "learning-by-doing" approach to diplomacy. At the risk of repeating myself: The mode was dynamic.

The learning presupposed an ability to make meaningful and relevant interpretations of local conditions and situations. I propose that this was what happened for two reasons: First, the overseas interaction was sufficiently commensurable with European standards to make possible a variety of meaningful understandings and communications. As this was the case, relevant understanding and actions increased over time.

\section{A methodological reminder}

The term "model" may be misleading if it is taken to mean that I suggest that Speelman worked out an explicit, general recipe on the "art of overseas diplomacy" in the Notitie. He did not. What we do find are descriptive overviews of the background and history of friend and foe, as well practical considerations and advice on how the Company could uphold the loyalty of its allies and maintain control over its former enemies. In fact, the very idea of a "general model" of overseas diplomacy runs counter to Speelman's mode of exposition and analysis in the Notitie, which focuses consistently actual cases. All the same, I have chosen to use the term "model" in the title because some general characteristic features of Speelman's thinking about and approach to overseas diplomacy can be reconstructed from his casuistic and concrete exposition. It is this kind of reconstruction that I intend to undertake in the following.

\section{Plan of exposition}

I shall start by briefly introducing Speelman's conceptualisation of the relative roles of treaties, military force, and diplomatic negotiations, before I turn to 
some of his considerations on diplomacy's role in upholding the Company's hegemony in general. I then point to some of Speelman's remarks on the importance of acquiring precise information on local conditions. The main body of the discussion constitutes an analysis of Speelman's case descriptions and assessments of old friends and former foes in South Sulawesi-more specifically, three of the Company's main enemies in Makassar, and the Company's principal ally, Arung Palakka. While all these cases have their peculiarities, they all highlight a characteristic feature of Speelman's "method," namely his keen eye on the personal character and human nature of the men of power with whom he dealt. Not least was his continuous assessment of how their personal characteristics could be used for the benefit of the Company. These traits go to illustrate that Speelman conceived of and handled overseas diplomacy in more "personalised" than "institutionalised" terms. That is but another characteristic of the empirical pragmatic approach.

I shall round off the survey on Speelman to suggest that even some traits in Speelman's physical appearance and personality contributed significantly to his diplomatic success, and that these attributes were reinforced by their compatibility with local perceptions.

\section{The limitations of treaty agreements in upholding the hegemonic regime}

Speelman certainly had no trust in treaties as a regulating means of interaction by itself. The Makassarese, he believed, would agree to any treaty without necessarily having any intention of honouring it. For instance, on the sultan's remark that the "Admiral (Speelman) decides everything and that there was nothing he himself could do about it, but to accept it," Speelman laconically remarks that this was "nicely put, but in reality not so intended." ${ }^{37}$ Promises of support from local allies could be even more confusing and less trustworthy. ${ }^{68}$

However much these examples seem to support Andaya's view of a collision of conceptions about the nature of treaties, one should first look at the weak institutional structure of diplomacy in Europe, and the European record of

67 "den Admiraal is meester van alles, Soo als hij ordonneert, moeten wij tevreeden zijn. Gunt van die zijde wel gezegt, maer niet gemeennt is." VOC 1276 OB, Inkomen Briefboek Makassar 1671, fol. $707 \mathrm{~b}$.

See for instance Inkomen Briefboek Makassar 1671, 718b-719b. 
broken treaties in the fifteenth and sixteenth centuries. ${ }^{69}$ More significant, contextual factors may do more than local political culture to explain Makassar's breaches of treaty with the Company in the period 1637-66. First there was an objective clash of interests in the Moluccas. Second, the terror of distance, and thus the Company's weak sanction power so long as it did not have a territorial base in Sulawesi, must have played a part in Makassarese risk calculations.

As it was, the context changed radically with the Company coalition's victory in 1667 and the establishment of Fort Rotterdam as the Company's colonial headquarters in Sulawesi. Speelman's historical account of the CompanyMakassar interaction between 1637 and 1666 serves to corroborate his view that treaties not backed by realistic military sanctions were of limited value.

\section{Speelman's account of the Company's interaction with Makassar up to 1666-the relative value of treaty regulations to military sanctions}

Speelman's description and analysis of VOC-Makassar interaction from 1637 up to the decision for the campaign on October 25, 1666, proceeds chronologically, using the three cycles of conflict, negotiations, and war, and treaties in 1637,1655 , and 1660 , respectively, as the structuring principle of his story. ${ }^{70}$ The prose is written in a neutral, objective tone with few comments. Thus, Speelman's view of the role of treaties in the Company-Makassar interaction can be reconstructed by implication.

Speelman depicts the "settled peace" of the 1637 treaty $^{71}$ as one that "settled all differences and issues between the two, with all conflicts solved and done with," excepting the issue of a permanent trading lodge for the Dutch. ${ }^{72}$ As for the period from the 1637 treaty to the outbreak of war in 1653, and the 1655 treaty, Speelman merely notes that interactions went on with ups and downs

69 See for instance, Anderson, The Rise of Modern Diplomacy, chapter 1, and Black, A History of Diplomacy, 43-59.

70 With the qualification of course that in 1637 there was no war between Makassar and the Company.

71 "vaste vreede" by Speelman consistently dated to 1636, VOC 1276 OB, Inkomen Briefboek Makassar 1671 , fol. $820 a$.

72 "alle verschillen, verwijderinghe veroorsaackt hebbende, bijgelecht ende vergeleecken." VOC 1276 OB, Inkomen Briefboek Makassar 1671, fol. 820a. 
until $1653 .{ }^{73}$ The incidents that took place that year, and Makassarese support of the rebels in Ambon are given as the reasons that "war came to break out."74 The outbreak of war is thus presented as a logical response to Makassarese provocations and breaches of the 1637 treaty.

As for the outbreak of the war in 1660 , Speelman simply states that the 1655 treaty was of such a nature that the High Government was displeased with it; he refers to its instructions to Van Dam and Truytman in 1660 as evidence. ${ }^{75}$ This statement of fact is all that Speelman offers as an explanation for the High Government's decision to go to war in 1660. Makassarese breaches of the 1655 treaty were by implication what had "led the Honourable Gentlemen to declare the 1655 treaty annulled and actions of war begun." 76 The brevity of the narrative needs no further explanation other than to remark that by 1660 the belief that a settlement with Makassar could be reached by good faith and treaties alone was a dead letter. ${ }^{77}$

Speelman attributes the decision for war in 1666 to continued Makassarese harassment, ${ }^{78}$ which led to Resident Verspreet's departure from Makassar and return to Batavia in 1665, and Wesenhagen's "unproductive negotiations" in February the following year. ${ }^{79}$

Speelman is hardly any more elaborate on the underlying reasons for the outbreak of open conflict here than in his treatment of the background of the 1655 and the 1660 wars. Although he refers to "the real reasons" 80 given in his instructions in October, ${ }^{81}$ in the Notitie the outbreak of the war is again explained as result of Makassarese provocations, namely the Makassarese invasion of

73 "sijnde dit soo onder diverse contenties, goede ende quade wederzijtse bejegeninge etc. gecontinueert." VOC 1276 OB, Inkomen Briefboek Makassar 1671, fol. $820 a$.

74 "tot een openbaar oorloch quam uijt te breken." VOC 1276 OB, Inkomen Briefboek Makassar 1671, fol. 820 .

75 "soodanich, dat hun Ed. Daervan haar misnoegen thoonden, connende blijcken, bij d' instructie voor d'Heer Van Dam en den Ed. Truijtman 1660 verleent." VOC 1276 OB, Inkomen Briefboek Makassar 1671 , fol. $820 a$. "wat rede Hun Ed.le gemoveert hebben, deselve . aff te breecken, en een aenslach op Pannekoka te maecken." VOC 1276 OB, Inkomen Briefboek Makassar 1671, fol.82oa.

77 See chapter 6.

78 “uijt de bedrugtinge van ongemaecq." VOC 1276 OB, Inkomen Briefboek Makassar 1671, 820a.

79 "sonder ijets te verrichten.", VOC 1276 OB, Inkomen Briefboek Makassar 1671, fol. 820a. Speelman seemed to have the correct dates confused, Wesenhage left for Makassar February 16, 1666, see Stapel, Het Bongaais Verdrag, 85, referring to DRB. For the events see Stapel, Het Bongaais Verdrag, 82-85.

80 "de eigentlijcke oorsaecken." VOC 1276 OB, Inkomen Briefboek Makassar 1671, fol. $820 a$.

81 VOC 1276 OB, Inkomen Briefboek Makassar 1671, fol. $820 a$. 
the Sulu Islands and the murder of Company personnel on Saleijer, and the plunder and murder in connection to the wreckage of the ship De Leeuwin. ${ }^{82}$

\section{Summary: The limitations of treaties}

In Speelman's historical survey of Company-Makassar interactions, these are represented as a continuous story of broken treaty terms by the Makassarese. The implicit lesson is that treaties unsupported by political control and a realistic recourse to military sanctions, were worth next to nothing. The functional treaty was one that could be protected and defended within the framework of a hegemonic political and military structure. In the post-1667 order, the alliance structure of the Bongaya treaty and Fort Rotterdam filled that function.

\section{On diplomacy's role in upholding the Company's hegemony in general}

Speelman ends his historical narrative of Company-Makassar interactions with a note of pride in the Company's achievements. With victory and the Bongaya Treaty, not only was peace restored in the land, it was restored with added glory and an enhanced reputation for the Company. ${ }^{83}$ Taking into consideration that the Company's hegemony rested on the various parties' loyalty to it as their supreme overlord, a boost to reputation was beneficial, and a main diplomatic challenge lay in protecting it. But the hegemonic system also rested on the preservation of peace among the local signatories of the Bongaya Treaty. In other words, as hegemon the Company had not only to oversee and keep the allied parties loyal to itself, it also had to concern itself with, and be prepared to interfere in, regional and local conflicts to preserve peace and order. I shall analyse Speelman's presentation of typical challenges in some of these axes and the respective means he recommended for handling them.

\footnotetext{
82 VOC 1276 OB, Inkomen Briefboek Makassar 1671, fol. $820 b$.

83 "in 't gantse land nu weder vreede, met veel meerder reputatie als te vooren." VOC 1276 OB, Inkomen Briefboek Makassar 1671, fol. 820 .
} 


\section{Bugis-Makassar relations}

The approaches towards the Bugis allies, on the one hand, and the erstwhile foe Makassar, on the other, had different ends at the outset. During the campaign and before the conclusion of the 1667 treaty, the challenge was to keep the alliance with the Bugis intact to crush Makassar. In the post-Bongaya order, the challenge regarding the Bugis was essentially to keep its loyalty intact and transfer it into the post- conflict order. For Makassar, the challenge was still to check and eventually pre-empt any ambitions of regaining its former power.

Balancing the power of the formerly dominant Makassar against the rising power of the Bugis proved a challenge. Speelman confided to the High Government that he was well aware that, after the fall of Sombaopu, the Bugis had started to feel uncomfortable about being tied too closely to the Company, ${ }^{84}$ and had from time to time approached Makassar. ${ }^{85}$ Contact had taken place in secret, without either asking for the Company's presence or informing it of the initiative. ${ }^{86}$ Although never explicated by Speelman, the Bugis initiatives not only represented a breach of loyalty, but also of the treaty, particularly article 25, which stated that all such contacts should take place with the knowledge of and in the presence of the Company's representatives. ${ }^{87}$ The High Government need not worry unnecessarily however over these secret negotiations, ${ }^{88}$ consoled Speelman, as nothing seems to have come of it. ${ }^{89}$ His advice on the matter is that one would do well to stick to the agreed articles of the treaty as far as possible and enforce them with discretion and firmness. ${ }^{90}$

It seems fair to suggest that although not explicitly proposed, what Speelman had in mind was a pre-emptive strategy based on balance-of-power thinking. The alliance with the Bugis should be maintained while keeping their ambitions in check. At the same time, it was important to not weaken the Makassarese

\footnotetext{
84 "De Bougijs in dees tijdt haer onder Comp's ontsach wat gevreest en geviert siende." VOC 1276 OB, Inkomen Briefboek Makassar 1671, fol. 821a.

85 "hebben nu en dan al meer met de Maccassaren genegotieert." VOC 1276 OB, Inkomen Briefboek Makassar 1671, fol. 821a.

86 "sonder van ons ijmant present te roepen off daer van kennisse te doen." VOC 1276 OB, Inkomen Briefboek Makassar 1671, fol. 821a.

87 Particularly art. 25 of the Bongaya Treaty. Corpus Diplomaticum, 2.378-39, see chapter 7.

88 "hoedanich negotiatie U,E. haer niet hoeve aen te trecken." VOC 1276 OB, Inkomen Briefboek Makassar 1671, fol. 821a.

89 "soo der dispuijt over viele." VOC 1276 OB, Inkomen Briefboek Makassar 1671, fol. $821 a$.

90 "maer de bekende poincten dienen naer vermogen en met discretie in vigeur gehoude te werden." VOC 1276 OB, Inkomen Briefboek Makassar 1671, fol. 821 b.
} 
too much. If so, a balance of power among the local powers, presided over and regulated by the Company, was to be a governing principle of Speelman's hegemonic order.

\section{Implications}

I regard Speelman's pragmatic reaction to the Bugis breach of contract and his trust in a balance of power to keep both the Bugis and Makassar pacified as illustrative of his pragmatic thinking. Power relations took precedence over insistence on legalisms. One does well to note that this pragmatic approach meant that an observant eye had to be kept on events at the two courts to identify any increase in dissatisfaction and opposition, but at the same time provocative action, which would result in unnecessary aggressive reactions on the part of either the Bugis elite or at the court of Makassar, had to be avoided. If that was true for the main ally and former main enemy, it was also true for the smaller political entities as well. In short, the hegemonic system was built on information and the interpretation of local political activities.

\section{The importance of acquiring precise information on local conditions as the general foundation of the Company's diplomatic performance}

In the introduction to the section headed "Description of the allies,"91 Speelman makes the limitations of his effort clear. His ambition is "not to give genealogical tables of rulers nor account for the precise jurisdiction and authority, or the military strength of their realms," 92 as that would have taken more time than he himself had at his disposal..$^{93}$ Drawing an encompassing political geography of South Sulawesi with the aim of organising the required political order among

\footnotetext{
91 "Beschrijvinge der Bontgenooten." VOC 1276 OB, Inkomen Briefboek Makassar 1671, fol. 708a ff.

92 (ick) "ben niet van sinne daer bij te doende geschlaghtreckeningen, eigelijcx jurisdictie van landen en heerschappijen, nogh sterckte van vermogen." VOC 1276 OB, Inkomen Briefboek Makassar 1671, fol. 708a.

93 "want dat een en andere vereijst wat meer tijdt, als ick nu over hebbe." VOC 1276 OB, Inkomen Briefboek Makassar 1671, fol. 708a.
} 
the local allies had to be left to his successors ${ }^{94}$ who would be able to assess the situation more accurately, ${ }^{95}$ Speelman seems almost to lament this.

In any case, for Speelman, the increase of knowledge based on experience or the accumulation of information on local conditions had to form the basis of the Company's power in South Sulawesi. And one should add that he was far too modest about his own contribution to it. The Notitie is full of information about political fissures, power factions, and the personal qualities of rulers and pretenders in South Sulawesi. This information is not a neutral survey, but a systematic political mapping necessary to preserve the Company's power.

Information about local power is typically presented at two levels of analysis in the Notitie, namely as an analysis of relations of power seen from an historical-contextual point of view, and from the level of personal agency. Of the two approaches, the latter takes primacy in Speelman's analysis. At the end of the day, from the Company's point of view the questions were who to approach because of their position and influence in the power hierarchy, and how to approach them to deter them from scheming against the Company, or how to win them over to the Company's side and make them useful to the Company.

The need for detailed information on local political conditions thus went with the institutional order of hegemony as such, but might have been enhanced by an appreciation of the fluid nature of the overseas context, where personal bonds were stronger than institutional ones. The latter called not only for accurate information on local political conditions, but for intimate knowledge and information about personal character to either bar unwanted persons from power or forge or renew bonds with desirable ones. If information on both context and agency prospects was equally indispensable, it was at the agency, or personal, level that the "art of diplomacy" was practised. The rest of this chapter is dedicated to an analysis of Speelman's performance and advice in four cases that concerned three of the Company's main adversaries in

94 "meest te staade sal comen voor den geenen, die het zijn wercq sal worden onder de bontgenooten selve de gerequireerde orde stellen." VOC 1276 OB, Inkomen Briefboek Makassar 1671, fols. 708a.

95 "wanneer oocq de perfectheijt best en claerest te ondervinden sal wesen." VOC 1276 OB, Inkomen Briefboek Makassar 1671, fols. 708b. 
Makassar-Karaeng Karunrung, the "young king" of Makassar, ${ }^{96}$ and the "king of Tello," ${ }^{\prime \prime}$ - as well as the Company's main ally in South Sulawesi, Arung Palakka.

\section{Considerations with respect to the foe: Karaeng Karunrung}

References to Karaeng Karunrung are scattered throughout the Notitie. In the description of the 1667 campaign, he appears for the most part as a secondary figure, but in the section on Makassar ${ }^{98}$ he is the subject of a lengthy and systematic treatment. In brief Karaeng Karunrung and his brother Karaeng Sumana fell in and out of favour with Sultan Hasanuddin from the 1660 s and up to the fall of Makassar. The two represented a hard and an accommodating approach towards the Dutch. In 1660 Karunrung been replaced as chief minister by the more moderate Sumana, and in 1664, Hasanuddin pressured the banishment of Karunrung from Makassar, whereupon the latter went to Banten and then Passir in Borneo. But in 1665, after the failure of a Makassarese embassy to Batavia in 1664, the peace party led by Sumana was discredited, and 1665 saw the return of Karunrung to the Makassarese court. ${ }^{99}$ Speelman's relation of Karunrung starts with a chronology of his falling in and out of favour at the Makassarese court. ${ }^{100}$ Speelman also offers a description of Karunrung's vices and virtues, and ends up with an account of his own abortive attempt to make Karunrung a Company ally. For economy of space, I shall limit my analysis to Speelman's characterisation of Karunrung's personality, and give some comments on the implications of Speelman's plan to make Karunrung an ally.

\section{On Karunrung's vices}

Intelligence and cunning in a cynical quest for power are the characteristic features of Speelman's depiction of Karunrung's political manoeuvring. Relating the

\footnotetext{
96 This must be Hasanuddin's son, I Mappasomba, in favour of whom Hasanuddin abdicated after the fall of Sombaopu, June 1669. See Andaya, The Heritage of Arung Palakka, 134, I shall be using Speelman's term.

97 This must be Karaeng Tello. Ibid. 121-22. I shall be using Speelman's term.

98 VOC 1276 OB, Inkomen Briefboek Makassar 1671, fol. 816b-819a.

99 Basset 1958, 34-35.

100 VOC 1276 OB, Inkomen Briefboek Makassar 1671, fols. 817bf.
} 
story of Karunrung's return to power in the court of Makassar, Speelman holds nothing back in depicting him as having a totally amoral and cynical personality. Karunrung's re-entry into court opened a Pandora's box of evil. He was now once again in position to "go on with his daily base deeds and ill-doings of murder, provocative behaviour and various sorts of black magic, just as before." ${ }^{101}$ This is a tale so horrifying Speelman goes on, "that it would be inappropriate for decent ears, as it would fill the listener with nausea, and if written down, would take piles of paper." ${ }^{102}$ Speelman then denounces Karunrung's base womanizing and lack of sexual morals: "No one can keep count of his numerous broken marriages, not to mention his concubines." 103 This went together with numerous murders of innocents initiated or committed by him. ${ }^{104}$

Speelman similarly condemns Karunrung's political machinations and motives as amoral. The recklessness of Karunrung's exercise of power is generally recognised by the Makassarese, states Speelman, yet no one dare speak out openly against him. ${ }^{105}$ Karunrung's motives are recognised as base too. All agree that he was out to ruin the realm for no other reason than to avenge himself on the kings of both Goa and Tello for their prior ostracism of him. ${ }^{106}$ In other words, if Karunrung was a base man as far as personal conduct is concerned, his political conduct and motives were no better.

A special case in which Karunrung's cynical politics and womanizing intertwined was his disgraceful abduction of Karaeng Saderbone's wife, a plot for which he recruited the king of Tello. Although rumours had it that Karunrung's intention was to marry his captive, there can be no doubt, states Speelman, that

101 "gaande voort alle sijne vulgaire dagelijcxe misdrijven, en quade comportementen van moord, (ongeschickte vertooningen, bemoeijenisse met tooverijen en anderer dergelijcke, dewelke superstitien, soo wel nogh in den jegenwordigen als in den voorganghe tijdt." VOC 1276 OB, Inkomen Briefboek Makassar 1671 , fol. 818 b.

102 "als sullende de vertellinge daervan voor eerbare ooren onbetamelijcq en met een affgrijselijcq wesen, behalven datter vellen papier met soude gevult worden." VOC 1276 OB, Inkomen Briefboek Makassar 1671 , fol. $818 \mathrm{~b}$.

103 "sijn getroude en weder verlaten vrouwen can hij selve niet mer tellen, ik swijge van sijne bijwijven." VOC 1276 OB, Inkomen Briefboek Makassar 1671, fol. 818b.

104 "Noch veel minder can hij opreeckenen de moorden, door hem selve gedaen, en door de sijne ten sijne bijwesen doen, sonder oorsaecke off waerom.” VOC 1276 OB, Inkomen Briefboek Makassar 1671 , fol. $818 \mathrm{~b}$.

105 "de Maccassaren groot en cleen, siende en observerende sijne directie tot hiertoe stellen vast, maer derven het niet openlijck uijtseggen.” VOC 1276 OB, Inkomen Briefboek Makassar 1671, fol. 818b.

106 "dat hij geen ander opsigt heeft, also om door een totael bederff van het gantse lant sich te wreecken, en te resenteren tegens de beijde coningen over sijne uijtbanninge." VOC 1276 OB, Inkomen Briefboek Makassar 1671 , fol. 818 b. 
he had no other intention than bringing her into disrepute and mistreating her. ${ }^{107}$ The political rationale seems to have been that the act of abduction itself not only brought the abducted wife into disrepute, but her husband, one of Karunrung's adversaries as well. In Speelman's eyes, Karunrung was thus a man in whom deviousness and evil in private and political affairs went together.

Yet, Speelman presents another perspective of Karunrung, viewing him in terms of his strategic use in maintaining the Company's power in Sulawesi. In this light, Karunrung comes out very favourably because of his strategic and cultural competence, which in actual fact may be viewed as an alternative, more positive, way of looking at some of the qualities we have seen Speelman condemn above.

\section{Karunrung's virtues}

"Putting his vices and dubious nature aside,"108 Speelman opened his description of Karunrung's virtues, "on the other hand one does well to appreciate him as a man of intelligence, well-informed about the world around him, and well experienced in both political and military strategy and tactics." ${ }^{109}$ Speelman further praised Karunrung's ability to keep calm and not easily be taken by surprise by unforeseen developments and events. ${ }^{110} \mathrm{He}$ is bright, ${ }^{111}$ possesses a good memory, ${ }^{112}$ and has a sharp eye for observation. ${ }^{113}$ When circumstances demanded, he could also act with the required leniency and forgiveness to tie bonds of allegiance with his people. ${ }^{114}$ In addition, Speelman holds forth that Karunrung has been taught in many trades ${ }^{115}$ and is well spoken. ${ }^{116}$

107 "Dat hij nu met de novo na ons vertrecq sal ten wijve nemen, ongetwijffelt met intentie om desselve dan daernaer in verachtinge te brengen, en met quaet tractement te beswaeren." VOC 1276 OB, Inkomen Briefboek Makassar 1671, fol. fol. 818b.

108 "Sijn boosheeden en quade nature aen een sijde geset." VOC 1276 OB, Inkomen Briefboek Makassar 1671 , fol. $818 \mathrm{~b}$.

109 "men mach hem aenhouden voor een heer van goet verstant, wereldkundich en gauw ervaren, soo wel in politie als oorlogsdirectie." VOC 1276 OB, Inkomen Briefboek Makassar 1671, fol.818b.

110 "Assurant en niet licht verset over onverhoetse toevallen." VOC 1276 OB, Inkomen Briefboek Makassar 1671 , fol. $818 \mathrm{~b}$.

111 “Scherpsinnich." VOC 1276 OB, Inkomen Briefboek Makassar 1671, fol. 818b.

112 "groote memorie." VOC 1276 OB, Inkomen Briefboek Makassar 1671, fol. 818b.

113 "naeuwkerig observantie." VOC 1276 OB, Inkomen Briefboek Makassar 1671, fol. 818b.

114 "oock near gelegenheijt door miltheijd 't volcq hem aenhangigh te maeken." VOC 1276 OB, Inkomen Briefboek Makassar 1671, fol. 818b.

115 “onderwesen in veel fraije exercetien.” VOC 1276 OB, Inkomen Briefboek Makassar 1671, fol. 818b.

116 “seer wel te tael." VOC 1276 OB, Inkomen Briefboek Makassar 1671, fol. 818b. 
Speelman went on to stress that one also had to take into account the cultural competence of Karunrung's upbringing and education. Karunrung's father had for instance let his son be taught by the Portuguese. ${ }^{117}$ Thus, not only did Karunrung speak perfect Portuguese, in addition to several local languages, he read and wrote them, too. ${ }^{118}$ All in all, concluded Speelman, Karunrung stands out as "the most competent of all the people of power in Makassar: none more so than him, none his equal, all of them below his standard." 119

Significantly, Speelman's praise of Karunrung is in terms of diplomatic and political strategic capability and not in terms of personal moral assets. Furthermore, Speelman's profile of political admiration for Karunrung comes close to a self-portrait; at least it is hard not to recognise qualities in Speelman's praise for Karunrung that he himself would not have taken pride in. But there was a more immediate practical dimension to Speelman's praise. Despite all his moral flaws, Karunrung was a man of political competence that could become very useful for the Company. In his virtuous aspects, Speelman considered him a "perfect partner," and so had moved to seek out the possibility of luring Karunrung over to the Company's side.

\section{Luring Karunrung over to the Company's side}

Immediately after the conclusion of the peace of Bongaya, Speelman had approached Karunrung to establish bonds of confidence with him. ${ }^{120}$ But although the prospects looked good in the beginning, in the end it did not work out. ${ }^{121}$ Speelman blames this on Karunrung's initial lack of confidence in him, which he attributed to his generally suspicious and conspiring mind. ${ }^{122}$

117 “door de bestel van de vader sijn meeste onderwijs en de instituatie bij de Portuguesen gehadt." VOC 1276 OB, Inkomen Briefboek Makassar 1671, fol. 818b.

118 "spreeckt hij perfect haere en versceijde anderer hierlandsche taelen, leest en schrijft se mede." VOC 1276 OB, Inkomen Briefboek Makassar 1671, fol. 818b.

119 "Summa boven alle regenten in Maccassar de bequaemste, dies noch in effect meester van sijne meesters." VOC 1276 OB, Inkomen Briefboek Makassar 1671, fol. 818b.

120 "waerom icq oocq al ten eerste near de vreede van Bonaeije gepooght hebbe, met denselven in vertrouwe te comen." VOC 1276 OB, Inkomen Briefboek Makassar 1671, fol. 818b.

121 "maer offschoon geleecq, dat het sich wel soude schicken, soo echter viel het naar mijnen sin niet uijt." VOC 1276 OB, Inkomen Briefboek Makassar 1671, fol. 818b.

122 "want gelijck hij was vol alderhande quade machines sulcx beswaert van gemoet, stacq hij oocq vol achterdocht, en dorffte sich darhalven aen mij niet vertrouwen." VOC 1276 OB, Inkomen Briefboek Makassar 1671, fol. 818b-819a. 
Karunrung's inherent devious nature thus aborted Speelman's scheme to make use of his virtues in the service of the Company.

That Speelman considered recruiting Karunrung to the Company's side despite his vices is still telling of Speelman's view of overseas diplomacy. Karunrung's personal vices were outweighed by his extraordinary political capability. One might even suspect that some of his vices, or at least his cynicism, might have counted as a politico- tactical asset so long as they were used in the service of the Company. In any case, Karunrung's political talents taken into the balance, the benefits were too tempting not to try to secure his cooperation. As such, the effort well illustrates the pragmatic nature of Speelman's overseas diplomacy.

\section{The young king of Makassar}

In Speelman's eyes, the "young king" of Makassar matched Karunrung's base morals. Inclined towards drinking and gambling in his youth, ${ }^{123}$ he continued these habits after coming into power. ${ }^{124} \mathrm{He}$ also demonstrated little interest in more serious matters (of state) ${ }^{125}$ for which he had received little training in his youth. ${ }^{126}$ The lack of education in affairs of state as a youngster probably would not have made much of a difference anyway considering that the king "should not be considered of the brightest kind" at the outset. ${ }^{127}$

In addition to his lack of moral standards, training, and intellectual capacity, Speelman also finds weaknesses of character in the sultan. He is a man of "no direction," 128 "nor resolution,"129 but "self-absorbed." 130 The young king was, in short, a man badly qualified to handle a crisis. ${ }^{131}$

Speelman's judgment of the young king's character flaws with political implications extended to a more personal, private level. He declared him extremely

\footnotetext{
123 "in sijne jonckhejt is hij genegen geweest tot drinken en speelen." VOC 1276 OB, Inkomen Briefboek Makassar 1671 , fol. fol. 819a.

124 "sedert in emplooij comende, is dat naer gebleven." VOC 1276 OB, Inkomen Briefboek Makassar 1671, fol. 819 a.

125 "heeft sich weijnig becommert in observatien van wightige saecken." VOC 1276 OB, Inkomen Briefboek Makassar 1671, fol. 819a.

126 "clein onderwijs ontfangen in sijn minderjarighheijt." VOC 1276 OB, Inkomen Briefboek Makassar 1671 , fol. 819 a.

127 "van deselve 't verstant niet groot sijnde." VOC 1276 OB, Inkomen Briefboek Makassar 1671, fol. $819 a$

128 "geen man van directie." VOC 1276 OB, Inkomen Briefboek Makassar 1671, fol.

129 “noch van resolutie." VOC 1276 OB, Inkomen Briefboek Makassar 1671, fol. 819 a.

130 "disponneert van sich selve." VOC 1276 OB, Inkomen Briefboek Makassar 1671, fol. $819 a$.

131 "niet vervaert en verset in tegenspoet." VOC 1276 OB, Inkomen Briefboek Makassar 1671, fol. 819a.
} 
petty, ${ }^{132}$ never rewarding any services, not even those of his house staff, ${ }^{133}$ and being inclined towards womanizing as well. ${ }^{134}$ In matters of religion, Speelman depicted him as a hypocrite, being outwardly demonstrative in his pious observances ${ }^{135}$ while his real concern was for personal enrichment only. ${ }^{136}$ No moral standards seem to have restricted his quest for more money; any means sufficed for him ${ }^{137}$ to the extent that he would (even) consent to do business with a street slave if he thought he could make even a marginal profit from it. ${ }^{138}$ In short, by Speelman's standards the king was more a petty peddler than a worthy ruler.

In addition, the sultan had a vengeful nature and was filled with hate for his foes, ${ }^{139}$ while he considered all his own faults and misdeeds as pardonable. ${ }^{140}$ He was "In all truth a mock king to serve as a Company king," 141 Speelman concluded. The young king was but a Company puppet, in other words.

This "caricature king," with all his faults and follies, was one that the Company could live well with. Tellingly, after his character assassination of the sultan, Speelman went on to speculate that the break of the Bongaya Treaty and the war that followed ${ }^{142}$ would probably not have taken place, if the real power had lain in the hands of the king instead of, as had been the case, with Karunrung. ${ }^{143}$ The implication is a familiar one, namely that one had to keep good intelligence about which individual or faction held actual power at the court, and to

132 "gierich boven mate." VOC 1276 OB, Inkomen Briefboek Makassar 1671, fol. 819a.

133 "loont gene diensten, sijne domestiquen selve krijgen niet." VOC 1276 OB, Inkomen Briefboek Makassar 1671, fol. 819a.

134 “genegen tot vrouwen.” VOC 1276 OB, Inkomen Briefboek Makassar 1671, fol. 819a.

135 "naer 't uiterlijcq, fijn in het gelove." VOC 1276 OB, Inkomen Briefboek Makassar 1671, fol. $819 a$.

136 "op sijn getijen, heel overgegeven tot geld conquestie." VOC 1276 OB, Inkomen Briefboek Makassar 1671 , fol. 819 a.

137 “'t sij op welcke wijse 't oocq wesen magh.” VOC 1276 OB, Inkomen Briefboek Makassar 1671, fol. 819 a.

138 "sullende een slave van de straet bij hem ter negotie admitteren, soo der een weinich winst bij is. VOC 1276 OB, Inkomen Briefboek Makassar 1671, fol. 819a.

139 “Wraeksuchtigh en haetdragent." VOC 1276 OB, Inkomen Briefboek Makassar 1671, fol. 819a.

140 "evenwel sijn alle misdrijven bij hem voor gelt vergeffeelijcq." VOC 1276 OB, Inkomen Briefboek Makassar 1671, fol. 819a.

141 "echter spuls genoch, om een Comp's coninck te wesen." VOC 1276 OB, Inkomen Briefboek Makassar 1671 , fol. 819 a.

142 See chapter 8.

143 "Dat de vreede van Bonaeije niet en soude sijn vervallen, soo hij sich selve meester waer geweest, en sijn eijgen sinlicheit opgevolgt ware, hebbende het oocq niet an hem geappert, onse successive aenmaningen van herten te amplecteeren, om een eijnde van 't oorloch te maeken. Dan gelijcq hij sijn macht langer onmactig was, soo en dorffde hij sijnen inentie niet te kennen geven, indien se was contrarie de opinie van Cronron." VOC 1276 OB, Inkomen Briefboek Makassar 1671, fol. 819a. 
support Company-friendly rulers however stupid they might be, following the principle that better stupid and friendly than smart and unfriendly.

\section{A shared implication in Speelman's characterisation of Karunrung and the young sultan of Makassar}

Although Karunrung stands out as the chief villain in the history of MakassarCompany relations, there can be little doubt that in Speelman's hierarchy of qualities in a ruler, Karunrung ranked well above the young king. For one thing, whereas Speelman kept a balance sheet between vices and virtues for Karunrung, he recorded no virtues for the young king at all. Some of what he found is detestable, but mostly he found harmless mediocrity. Karunrung's vices seem to imply a certain "grandeur" when compared to the sultan's mediocrity, and to reflect a complementary side of a man of great intelligence, strategic insight, and the ability to act wisely.

I suggest this contrast in depiction reflects that Speelman felt he shared more with the cunning politico-military Karunrung than with the ruler who cared more about satisfying his own lusts and greed than to rule. In this configuration, Karunrung represented a "worthy opponent" whom one should try to lure over to the Company's side. The small- minded, money-seeking sultan, the Company's "mock king", represented but a comical figure of nominal power who the Company could manipulate for its own ends.

\section{The king of Tello}

In the introduction to the characterisation of the King Tello we are, as in the case of the young king of Makassar, presented with the picture of an untrained, incompetent, and spoilt man of power. Only seven months old when recognised as ruler following the sudden death of his father, ${ }^{144}$ the king of Tello's training as a political leader was totally neglected during his childhood. He was not instructed in political matters, but simply left free to follow his personal impulses, whatever they might be. ${ }^{145}$

\footnotetext{
144 VOC 1276 OB, Inkomen Briefboek Makassar 1671, fol. 819a.

145 "maer heel niet geinstrueert, noch in eenige saecken onderricht, volgende onbecommert sijne begeerlijckheijt, 't sij dan goet off quat." VOC 1276 OB, Inkomen Briefboek Makassar 1671, fol. 819a.
} 
Still, Speelman is less critical of his personal vices than he is of either the young king of Makassar or Karunrung. There are no tales of big scandals and excesses told about him, ${ }^{146}$ but neither was there much to praise him for. ${ }^{147}$ The king of Tello stood out in Speelman's description as a grey man of little significance. He was not of evil temperament, ${ }^{148}$ but he does not seem to have been particularly keen on amassing riches for himself either. ${ }^{149}$ Of the extensive means left to him by his inheritance, a lot had been squandered in gifts to women whom he consecutively married and then left. ${ }^{150}$ Apart from this, he seems to have been preoccupied with nothing other than sleeping, eating, and pleasure seeking. ${ }^{151}$

Besides showing little interest in politics, the king of Tello also seems to have felt uncomfortable with the attendant responsibilities. ${ }^{152}$ Still he was not a devious man, ${ }^{153}$ though he seems not to have possessed a lot of courage. ${ }^{154} \mathrm{~A}$ man of little significance, and so seemingly harmless, one would conclude. Still, Speelman noted that after the "last peace" a change could be spotted in the king in that he seemed to have become more observant of political matters, and had started to look behind his back." ${ }^{155}$ This called for an intensified courtship by the Company as it might open the opportunity to bind the king closer to it.

\section{Advice on how to approach the king of Tello}

The political message from Speelman to the High Government and his successors in Makassar was that although the king of Tello seemed to represent

146 "Heele groote uitjspoorigheden ofte quade comportomenten worden van hem niet vertelt." VOC 1276 OB, Inkomen Briefboek Makassar 1671, fol. 819a.

147 “veel loff en wert hem oocq niet toegeschreven." VOC 1276 OB, Inkomen Briefboek Makassar 1671, fol. 819 a.

148 “quaetaertigh is hij niet." VOC 1276 OB, Inkomen Briefboek Makassar 1671, fol. 819a.

149 “onbequam om schatten te samelen." VOC 1276 OB, Inkomen Briefboek Makassar 1671, fol. 819a.

150 "De middelen hem naergelaeten sijn veele, vermindert met begiftinge van vrouwen, die hij al eenige getrout en weder verlaeten heeft." VOC 1276 OB, Inkomen Briefboek Makassar 1671, fol. 819a.

151 "bemoeijt sich nergens met als met slaepen, eten en vermaeck te soecken. VOC 1276 OB, Inkomen Briefboek Makassar 1671, fol. 819a.

152 "onbequaem tot het bestier van saecken." VOC 1276 OB, Inkomen Briefboek Makassar 1671, fol. 819a.

153 "maer niet valsch off bedrieghlelijck." VOC 1276 OB, Inkomen Briefboek Makassar 1671, fol. 819a.

154 “Sijn couragie wert niet seer gelaudert." VOC 1276 OB, Inkomen Briefboek Makassar 1671, fol. 819a.

155 "Evenwel schijnt hij sedert de laetse vreede wat andachtiger te sijn geworden, beginnende oocq wat achterrugge te sien.” VOC 1276 OB, Inkomen Briefboek Makassar 1671, fol. 819b. 
neither a potential threat nor a particularly useful ally to the Company, one would do well to look out for his "political awakening" or if he should start to harbour political ambitions of his own that could be turned to the benefit of the Company. In view of the king's recent political reorientation, he might be drawn over to the Company's side. But that would take planning and due caution. The task of pursuing the switch of loyalty had to be put in the hands of a "trustworthy agent," and one had to take care to isolate the king from "agents with bad influence."156

Working in favour of this scheme was that the king of Tello stood in higher esteem among the population in Makassar than, and was clearly preferred as a ruler to, both the king of Makassar and Karunrung. ${ }^{157}$ So, all in all, prospects did not look bad; at least they were presented as being well worth pursuing. What it would take was clever diplomacy. In Speelman's conceptualisation, and in Company's conceptualisation generally I would say, that meant a man with knowledge of and competence in local thinking and modes of behaviour. If "clever diplomacy" had to be performed by agents well versed in local ways and manners of doing things, the discovery of opportunity for increased Company influence had to be based on assessments of the local situation. Company self-sufficiency and Eurocentrism would have been counterproductive in both cases.

\section{Summing up: The implications of Speelman's assessments of the Makassarese foes}

There can be no doubt that for Speelman, the major flaw in the king of Tello's character, as it was in the case of the young king of Makassar, lay in his lack of interest and training in matters of state. Speelman's harsh judgement of both in this respect represents a complement to his admiration for Karunrung's political competence and abilities. By implication, Speelman's condemnation also demonstrated his own political credo, namely that one must know about affairs of state to take part in them successfully. By

\footnotetext{
156 "Men sal hem genoeghsaem near Comp's intentie connen leijden ... als men door ijmaent, die men vertrouwen magh, quade instrumenten van hem weert." VOC 1276 OB, Inkomen Briefboek Makassar 1671 , fol. $819 \mathrm{~b}$.

157 "Bij het volcq van Goa en Tello is hij verre veel getrocken en bemint, boven den conincq van Goa ende Cronron." VOC 1276 OB, Inkomen Briefboek Makassar 1671, fol. $819 \mathrm{~b}$.
} 
implication, for the Company to take part in local politics, it had to learn about their workings, not to speak of what it took to protect and defend its hegemon position.

It goes for all three of these character assessments that although some of Speelman's observations might resemble gossipy journalism, the gossip in the final instance served a political purpose as part of an assessment of how to act towards these men of power to gain maximum Company influence. In the case of Karunrung, Speelman tried to win him over to the Company's side because of his exceptional abilities; in the case of the young king Makassar, one was better off leaving him be and not provoking him, harmless as he is in his indulgence in private pleasures, and use him as a "mock king." In the case of the king of Tello, one could well have left him be too, if it were not for the fact that his new interest in politics might open new opportunities. It was better to explore and pursue that possibility. Speelman's "gossip" was not "gossip" per se; it was an essential part of his political survey for defending the Company's political hegemony.

\section{A return to the information dimension}

A nicer word for "gossip" is "information." As for Speelman's information about local affairs, he makes explicitly clear that it was based on his personal experience of the kings on site, both friends and foes. ${ }^{158}$ But he also made it clear that he might have gotten some facts wrong, or that facts might emerge that would be contrary to what he had related. ${ }^{159}$

It is beyond my ambition at present to point out what Speelman might have missed or even gotten wrong. What should be noted, however, is that both the implications of Speelman's analysis of local power and his own self-proclamation of their inherent shortcomings point towards a critical approach that is diametrically opposed to a dogmatic Eurocentrism.

\footnotetext{
158 "Dit sij geseght van de voors. 3 princen naer de presenten tijdt, soo uitgenoome informatie, als eijge bevindinge, staande mijn aenwesen hier omtrent, dat icq deselve als vriend en vijant gefrequenteert hebbe." VOC 1276 OB, Inkomen Briefboek Makassar 1671, fol. 819b.

159 "connende niet te min wel sijn date er ergens in mijn voorgaende schrifturen wel iets contrarie desen gevonden wierde." VOC 1276 OB, Inkomen Briefboek Makassar 1671, fol. 819b.
} 


\section{Three aspects of keeping the alliance with Arung Palakka}

In the case of Arung Palakka, the situation was inverted compared to Karunrung and the other foes. It was the task of keeping Palakka as the glue that held together the alliance with the Bugis states that constituted Speelman's overriding challenge and concern. However, his diplomatic approach towards Palakka remained the same as it was in the case with Karunrung; a personalised, pragmatic approach.

Speelman's point of departure in his analysis of Arung Palakka was that both the Company's political hegemony and political stability in Sulawesi depended on his position as uncontested leader of the Bugis. It was not merely important, it was vital; the success of the campaign and the integrity of the Company's hegemony depended on it. There were two potential obstacles to reaching that goal; that Bugis unity would fall apart with the death of Palakka, or that Palakka would lose his hitherto uncontested position as leader of the Bugis. Speelman sought to pre-empt these threats by appealing to both local and non-local traditions.

I have selected three cases that illustrate the composite nature of overseas diplomatic challenges as well as Speelman's pragmatic approach to handling them: his use of Palakka's claim to Soppeng and Bone on the grounds of dynastic rights and heritage; his handling of the succession issue in the event of Palakka's premature death; and the issue of Palakka's speculations on religion as a possible threat to his position should his speculations be known. The first and last were argued in terms of local tradition, the second reflects the institutional difference between the South Sulawesian polities and the Company.

\section{Legitimacy by dynastic claims and historical tradition}

Speelman began his description of Arung Palakka ${ }^{160}$ by laying down the legitimacy of his claims to kinghood in the Bugis realms of Bone and Soppeng. It was a claim based on dynastic legitimacy: Palakka was connected by family ties to both the ruling houses of the Bugis. ${ }^{161}$ Palakka's claim to Bone needed

\footnotetext{
160 For Speelman's description of Arung Palakka in the Notitie, I build on VOC 1276 OB, Inkomend Briefboek Makassar 1671, fols. 708b ff. and 746a ff.

161 "vermaghschapt aen de beijde hooge huijsen der Bougjis." VOC 1276 OB, Inkomen Briefboek Makassar 1671 fol. $708 \mathrm{~b}$.
} 
no extra argument, considering that he came from one of the highest-ranking families there; ${ }^{162}$ but for Soppeng, the situation was more complicated, as Palakka was only indirectly related to its royal house. ${ }^{163}$ Speelman's approach to arguing for Palakka's right to Soppeng was thus made primarily in historic and only indirectly dynastic terms. The logic of the legitimacy of Palakka's claim was that as Soppeng was a dependency of Bone, ${ }^{164}$ so by his dynastic rights to Bone Palakka was in fact a legitimate pretender to the throne of Soppeng, too. He was, claims Speelman, a legitimate pretender to both the royal houses of Bone and Soppeng, by force of traditional custom as well as by legal rights." ${ }^{65}$ The point here is that whereas neither the dynastic nor the historical claim to sovereignty was foreign to European tradition, one would have to know something about local South Sulawesian affairs to discover Palakka's claims to the lineage as Speelman does. That Arung Palakka must have been one of his main sources here does not detract from the fact that Speelman regarded this information as vital to an understanding of the political structure and workings of the political system.

\section{Surveying local political power relations}

Speelman also analysed the political implications of not only dynastic heritage but of current marriage alliances as a source of power. In his account of the quality of Bugis leaders under Palakka's command ${ }^{166}$ is, for instance, one Arou Vacqua, who was married to Palakka's sister. ${ }^{167}$ The marriage tie was obviously seen as leveraging Palakka's "alliance capital," as Vacqua was a lesser prince of Soppeng. ${ }^{168}$ This is but one instance of how Speelman surveyed constellations of local power relations. His listing of genealogical records and marriage alliances, as well as his surveys of local lord-vassal relations and dependency relations all

\footnotetext{
162 "en onder die voor eene van de hooghste rangh." VOC 1276 OB, Inkomen Briefboek Makassar 1671, fol. fol. $708 \mathrm{~b}$.

163 VOC 1276 OB, Inkomen Briefboek Makassar 1671, fol. 708 b.

164 “eijgelijck te reeckenen voor en steende en onderhoorigh Koninckrijck van Bone." VOC 1276 OB, Inkomen Briefboek Makassar 1671, fol. $708 \mathrm{~b}$.

165 "de een en ander soo na is dat hij buijten infractie van outheden couthumen en wetten sustineert, soo wel tot conincq van Soppingh als tot coninq van Bone te comen en te mogen gecooren worden." VOC 1276 OB, Inkomen Briefboek Makassar 1671, fol. 746a.

166 VOC 1276 OB, Inkomen Briefboek Makassar 1671, fol. 709a ff.

167 VOC 1276 OB, Inkomen Briefboek Makassar 1671, fol. 709a.

168 VOC 1276 OB, Inkomen Briefboek Makassar 1671, fol. 709a.
} 
constitute specific aspects of a mapping of local power in South Sulawesi; and that mapping was an indispensable element in the Company's diplomatic structure.

Two questions still arise: Was Speelman's information reliable? And was Speelman capable of interpreting the information he received reliably? A lot of his information must have come from Palakka himself, the rest from local sources, so at least most of it must have been factually correct. And even if such was the case, was Speelman in a position "understand" its deeper implications? According to Andaya, as a European, Speelman was "culturally blocked" from acquiring a deeper understanding. I have two counterpropositions. First, insofar as the interactions between the Company and local powers are concerned, the political cultures of Western Europe and Southeast Asia were sufficiently compatible for a pragmatic transcultural, if still not "perfect," understanding.

None of the cases of legitimacy claims that Speelman explored in detail needed "cultural translation" to achieve a workable understanding in the first place. All were compatible with seventeenth-century Western European political culture. The dynastic principle was the main source of power legitimation in Western Europe, to the degree that even if one considers the Dutch Republic as something of an exception, it still applied to the power position of the House of Orange.

Second, one should note that Andaya's argument rests on the assumption that locals had only one model of political communication at their disposal, their own. But why would they apply that without modifications in transactions with outsiders? The evidence both in the Makassarese use of the Portuguese and in their dealings with the Dutch suggests, to the contrary, that they "imported" what they thought useful, and tried to fend off whatever threatened their freedom of action and autonomy from the outsiders. This points towards a quite different and dynamic interaction logic than that allowed for by the proposition of static mutual misunderstanding. Speelman's cultural competence acquired from his long overseas experience and his fluency in Malay also seems to suggest that he would not have consistently been blocked from understanding local conditions and structures. ${ }^{169}$

169 See, for instance, Stapel, Cornelis Janszoon Speelman, ix. 


\section{The concern over Arung Palakka's lack of legitimate heirs}

After laying out Palakka's genealogy and its political implications, Speelman went on to comment on Arung Palakka's four (official) wives. His "first wife," long a resident in Batavia when Speelman wrote, descended from the kings of Gowa and Saderbone on her father's side and was thus, remarks Speelman, generally to be regarded as of Makassarese descent. ${ }^{170}$ Putting aside Speelman's personal characterisations of her, based on second-hand opinion and on private conversations with Palakka, ${ }^{171}$ the issue was basically political, although there seems to be some disagreement over the role of heredity in the Bugis tradition. Noorduyn for one stresses that the Bugis kingdoms, were "strictly hereditary in character", ${ }^{172}$ although he also admits an aspect of pragmatism, or "pragmatic opportunism" as he calls it in the fact that "people oriented themselves to the person who manifested the greatest concentration of power." ${ }^{173}$ On the other hand Pelras holds that in the Bugis kingdoms no office was properly speaking hereditary, although it was not uncommon for a son or daughter to succeed a parent. ${ }^{174}$ Whatever difference of opinion, there still can be no doubt that for Speelman and the Bugis nobles who he was discussing the matter with, the issue was who should succeed Palakka if he should pass away.

By right of his first wife's descent, Arung Palakka had a legitimate claim to the throne of Makassar. In this regard, his first wife represented both a political asset and a liability. Apart from the prestige inherent in her dynastic heritage, she was regarded with high esteem at the court of Makassar. ${ }^{175}$ But her status also represented a potential danger. This came to the surface in Speelman's response to Palakka's raising the issue of the return of the first wife to Sulawesi. Palakka had put the request gently by asking Speelman "whether he thought

\footnotetext{
170 "Sulcx in 't generael van Maccassarse affcomste." VOC 1276 OB, Inkomen Briefboek Makassar 1671, fol. $747 \mathrm{a}$.

171 "gelijck oocq Sijn Hoogheijt daer van mij betuijcht heeft." VOC 1276 OB, Inkomen Briefboek Makassar 1671 , fol. $747 \mathrm{a}$

172 Noorduyn, 2000, 113,

173 Noorduyn, 2000, 116.

174 Pelras, 1996, 179, 184.

175 “onder de eersten spraecken de Maccaarse coningen seer met groote genegenheijt van desselve." VOC 1276 OB, Inkomen Briefboek Makassar 1671, fol. 747 a.
} 
the High Government would object to it." ${ }^{176}$ Speelman recorded that "he had laughed it away as if that was no issue at all." ${ }^{177}$ But Speelman's laugh in this instance was tactical. On this issue, there is reason to believe that Speelman was double-playing Palakka, or at best was not being totally open with him.

The Company's hegemonic position rested on preserving a relative strength compared to its Bugis allies. The possibility of a Bone- Makassar union, which Palakka's marriage to his first wife made possible and which a return of her to Sulawesi would actualise, could possibly have jeopardised the Company's hegemony in South Sulawesi. Tellingly, after having related his reply to Palakka on the issue on the repatriation of the first wife, Speelman addressed the High Government directly, revealing that he himself had done nothing further to push the matter. ${ }^{178}$ The final decision on the issue he left to the Council, ${ }^{179}$ but he himself was of the conviction that it would be wise to keep an eye on the first wife's association with the Makassarese, "as she is said to possess bold ambitions." ${ }^{180}$ Speelman's fear was that the presence of the first wife in Makassar might well prove a distracting factor in Palakka's war effort and that she may well harbour political ambitions of her own. Concerns of political strategy held primacy over personal friendship at the cost of feeding Palakka with false expectations.

On the other hand, Speelman made a detailed "tour de force" of personal intimacy when describing Arung Palakka's three other official wives. On the one hand, this goes to illustrate the fact, often overlooked or understudied in the historiography, that there were personal friendships and emotional bonds between Company commanders and local allies. After all, Speelman and Palakka were brothers in arms who fought together and drank together, and thus knew each other's personal weaknesses, faults and, not least, emotions. In

\footnotetext{
176 "off dan de Hooge Regeeringe wel toelaten soude, dat sij met hem ginge." VOC 1276 OB, Inkomen Briefboek Makassar 1671, fol. 747a.

177 "daer icq doorgaens om lachte, in sulches schijn, als off dat geen vrage waert was." VOC 1276 OB, Inkomen Briefboek Makassar 1671, fol. $747 \mathrm{a}$.

178 "Tot nogh toe heb ick althoos daer geene geinclineert, van deselve ginder te doen verblijven, dat met fatsoen, staende het oorlogh, conde geschieden.” VOC 1276 OB, Inkomen Briefboek Makassar 1671, fol. $747 \mathrm{a}$.

179 "Wat hun Ed.le nu voorts daerinne disponeren sullen, staat te besien." VOC 1276 OB, Inkomen Briefboek Makassar 1671, fol. 747a.

180 "benick van gevoele, dat het niet onnoodigh sal wesen soo se hier coomt, op hearer ommegangh met die van Maccassar goede acht te geven, zijnde, near ick hoore, oocq seer ambitious en grootshertigh." VOC 1276 OB, Inkomen Briefboek Makassar 1671, fol. 747a.
} 
short, it was human beings, not cultures or legal systems, that were interacting. But if the human factor should not be underestimated in the study of diplomatic practice, Speelman's basic issue concerning Palakka's wives was still basically about power.

The political dimension comes fully to the fore when Speelman rounded off his survey of Palakka's marriage alliances with a brief conclusion on his many by-wives, whom he did not really consider "proper wives." 181 Official wife or by-wife is not the issue, however. The issue is the lack of legitimate heirs to Palakka, and who should then succeed him in the event of his premature death.

As for the by-wives, they could be dismissed or treated more lightly than the four "official" wives because the former could not produce legitimate heirs comparable to the ones produced by the "official" wives. ${ }^{182}$ The problem was, however, that none of Palakka's official wives had yet produced any legitimate successor either. ${ }^{183}$ The closest in the line of succession were thus Palakka's four sisters, all of whom at the time resided in Batavia. ${ }^{184}$

This situation left the matter of the succession of Arung Palakka with all its implications for the political stability and preservation of the Company's hegemony hanging in the air. And Speelman could not let it hang there, the issue was too pressing. The alliance with the Bugis with Arung Palakka as king of both Bone and Soppeng formed the cornerstone of Speelman's plan for Company hegemony in South Sulawesi. An unsolved succession procedure thus represented a potential obstacle for Speelman's venture and the Company's cause in Sulawesi as such. It therefore posed an immediate challenge.

\section{Establishing an agreed succession procedure}

During the campaign, writes Speelman, he had often discussed the matter of succession in the case of Palakka's sudden death with other Bugis leaders. ${ }^{185}$ The key questions were who might be trusted to fill his position as leader of the

\footnotetext{
181 "nu niet veel in aensien als eijge wijven werden gehouden." VOC 1276 OB, Inkomen Briefboek Makassar 1671, fol. 747b.

182 VOC 1276 OB, Inkomen Briefboek Makassar 1671, fol. 748a.

183 "Geene kinderen heeft sijn Hoogheijt van al sijne wijven, nogh bijwijven geprocureert, oocq bij gene van de affgaende en aengecoomende soorte, soodat hij is sonder eenigh wettige eerffgenaem." VOC 1276 OB, Inkomen Briefboek Makassar 1671, fol. 748a.

184 VOC 1276 OB, Inkomen Briefboek Makassar 1671, fol. 748a.

185 “geconfereert." VOC 1276 OB, Inkomen Briefboek Makassar 1671, fol. 748b.
} 
Bugis peoples, and how it would be possible to go on fighting the war with undiminished stamina. ${ }^{186}$ The response, according to Speelman, had been evasive and inconclusive on all occasions. The Bugis commanders neither wished to discuss the matter, ${ }^{187}$ nor had they been willing to point out any likely successor candidates. ${ }^{188}$ All the same, both parties had agreed that it would be necessary to have a plan in place in case Palakka should be indisposed or pass away. ${ }^{189}$

As can be seen from the effort that Speelman put into it, the issue represented a pressing problem of the highest priority, but it was a difficult challenge that required considerable tact. In a meeting where the most prominent Bugis leaders were present, Speelman relates that he had once again put forward the issue in the most "discrete manner" 190 at the end of the session. The response from the Bugis leaders left much to be desired. All of them declared that they were willing to die with the prince if he were to be killed by the enemy. ${ }^{191}$ Speelman put little faith in this declaration, however, cynically adding in parenthesis: "words come easy, but deeds had already proven differently to our men." 192

Speelman, then, obviously pressing for a more decisive solution, collective suicide would hardly solve the problem, presented a scenario in which Palakka had died of illness, that is a situation in which demonstrative self-sacrifice made no sense. The Bugis leaders' response to this scenario was that in such a case they would have no alternative but to turn to the Company. ${ }^{193}$ Still, they refrained from any commitment to identify Palakka's successor. ${ }^{194}$ By implication, the Company was made an integral component in the appointment of a

186 "waeraen men in cas van Radjas verongelucken offte affsterven het gesagh, aen hem over de Bougijse volckeren gedefereert, weder met gerustheijt toevertrouwen ende overgegeven mochte, tot vermijdinge van 't oorlogh derselver." VOC 1276 OB, Inkomen Briefboek Makassar 1671, fol. 748b.

187 "daer zij evenwel niet geerne spraecken." VOC 1276 OB, Inkomen Briefboek Makassar 1671, fol. 748b.

188 “en nogh veel minder om verklaeren van ijmant te doen.” VOC 1276 OB, Inkomen Briefboek Makassar 1671 , fol. 748 b.

189 "hoewel zij selve oordeelden heel nootsaeckelijcq, dat het diende te geschieden." VOC 1276 OB, Inkomen Briefboek Makassar 1671, fol. 748b.

190 “op een gevoelijcque wijse ten tapijte gebraeght." VOC 1276 OB, Inkomen Briefboek Makassar 1671, fol. 748 b.

191 "Ijgelijck woude sterven met sijn Hoogheijt, soo hij stierff van 's vijants hant." VOC 1276 OB, Inkomen Briefboek Makassar 1671, fol. 748b.

192 "woorden sijn dogh niet duijr, 't contrarie van dit opgeven was ons volck al gebleven." Ibid. fol. 748a.

193 "maer van sieckte, daer niets tegen te doene was, zij hadden geen andere toevlught als aan de Comp.e." VOC 1276 OB, Inkomen Briefboek Makassar 1671, fol. 748a.

194 "en conden derhalven niet seggen, wie in sulcken cas van hun des coningx plaetse hoorde te becleeden." VOC 1276 OB, Inkomen Briefboek Makassar 1671, fol. 748a. 
successor to Arung Palakka. But, this was by implication only. The Bugis leaders' response to the succession issue confronted Speelman with a situation in which he neither got any explicit proposals for a plan of action nor suggestions for a procedure to which the ally was totally committed. This was unacceptable for him.

At the same time, the situation might have struck Speelman as ironic, because he was confronted with a situation that would have appeared ideal, given that the Company wanted to establish a kind of direct hegemony over the Bugis. All it would have taken would be to wait for, or even arrange, Palakka's death in battle or otherwise at a convenient moment when control over Makassar had been secured. After all, a situation of political paralysation or conflict in conjunction with a succession crisis was normally viewed as a "golden opportunity" for political intervention in local affairs. ${ }^{195}$ But in the case of Palakka, the conditions were the other way around. Palakka was the indispensable ally without whom the campaign stood to lose its impetus and pace, or fall apart altogether. The plan for his succession was an emergency plan, to secure the success of the whole venture of establishing and upholding Company hegemony in South Sulawesi in case of his premature death.

If Palakka should die on campaign, Speelman could hardly hope for a replacement by a man of comparable status and standing among the Bugis. But he could at least hope for a replacement process in which the Bugis leaders themselves took part, and dedicated themselves unanimously to one and the same candidate. A candidate anointed by the Company alone could hardly expect to be met with the same recognition. So, in this case Speelman was confronted with a situation where he had to take on the role of mediating and arbitrating positions within his local ally camp.

As it was, a plan of action in case of Palakka's premature death was finally agreed upon between the Bugis leaders and Speelman. The nobles declared that they would have no other choice than to turn to the Company, and would therefore not be in a position to declare who should succeed Palakka. They would, however, comply with whatever the Company recommended. And, as they recognised the king of Soppeng as their legitimate overlord, they would also be loyal to his choice for Palakka's successor, which he and the Company

195 Banten 1682 is a classic case, also with Speelman as the executor for the establishment of Company hegemony. See De Jonge, Opkomst, 4.clvi-1clxxi. 
would come up with together. ${ }^{196}$ There then followed a discussion about who would be the least controversial and most competent ruler, about which no conclusion was reached. The matter was finally resolved when the lord of Soppeng and Palakka without further ado simply declared the princes of Craijo to be the primary of the candidates, and thus the group from which the Company should make its selection. ${ }^{197}$

So, even if postponing the actual selection of a specific candidate, the agreement at least produced a procedure with a built-in guarantee of legitimacy by involving the Bugis directly. It was probably the best Speelman could get at the time.

Two preliminary lessons can be learnt from Speelman's tackling of the challenge of securing a succession procedure with the Bugis leaders. Accepting for the sake of argument that Speelman had a deficient understanding of cultural perceptions of power underlying the Bugis unwillingness to name a successor to Palakka, in the end he did reach a solution that both parties could accept. That must have taken at least some cultural competence. Second, the discussion about the succession procedure illustrates an important aspect of what overseas diplomacy was about in general, namely negotiations with local leaders on ad-hoc issues as one went along.

No one even remotely sane would do that without taking into consideration the mode of thinking of the local negotiation partners. The baffled way in which the scenario of Palakka's sudden death was received and tackled by the Bugis leaders might be taken as an indicator of a political environment with a low degree of institutionalisation. In contrast, Speelman's insistence on a rational, predetermined solution to the succession issue might be taken as indicative of a political tradition in which the impersonal took primacy over the personal. But such a structural contrast in which Speelman's positions are taken to have been "dictated" by a pre-imported notion of the institutional holding primacy over the personal misses the mark or is incomplete at best.

As we have seen in other instances, Speelman's reflections on diplomacy towards his Makassarese foes and his Bugis friends demonstrate a tuned appreciation of the "personality factor." A better way of explaining Speelman's pressing for an institutional solution to the succession of Palakka than as an

\footnotetext{
196 "Sij soude alles doen 't gene wij haer deden aenbevelen en erkennende sij hem ook in alles gehoorsamen, insgelijcx dengeene, die hij daer met ons soude goetvinden in plaetse van sijn Hoogheit te laten succederen." VOC 1276 OB, Inkomen Briefboek Makassar 1671, fol. 748a.

197 VOC 1276 OB, Inkomen Briefboek Makassar 1671, fol. 748b.
} 
overreliance on familiar institutional Procedures, is that it was conditioned by context. While predictability as in this case was crucial, Speelman reverted to institutional arrangements because it came closest to insuring the Company's situation. One should also bear in mind that it was partly the charismatic dimension of Palakka's political power that made it so crucial for Speelman to construct an institutional safeguard for a continued alliance between the Bugis and the Company should he pass away. The established institutional solution then represented a pre-emptive device made particularly pressing because of the lack of, or weak, local alternative, an example of a pragmatic approach, although one with a familiar European outcome.

I shall conclude with a discussion of Speelman's pragmatic handling of a totally different issue, namely the threat to Palakka's personal prestige and standing with the Bugis, should he make his personal speculations on religion public.

\section{Arung Palakka's personal charisma and the hazards of going public with his religious speculations}

To a large degree, Palakka's political capital rested on the popularity he held with his men, which did not go unnoticed by Speelman. Illustrative is the latter's recording of an instance in which many of Palakka's men, at a time when they thought him dead, were brought to tears of joy and affection to see him alive and well. ${ }^{198}$ This is another example in Speelman's text in which he comments on emotions. But once again, his objective was to accentuate the political considerations. Not only did Arung Palakka's dynastic heritage identify him as legitimate king of Bone and Soppeng, his personal charisma secured his place as the undisputed leader of the Bugis. This must be upheld. Yet, the prince was in danger of jeopardising his personal prestige by making his thoughts on religion public.

On several occasions, states Speelman, Palakka had confided in him about his animosity towards Islam and announced that he was inclined to renounce his faith, having become more sympathetic towards Christianity. ${ }^{199}$ The only

\footnotetext{
198 "In desen generale toeloop bleecken actien van lieffde niettemin, die veele Bougijs over vreughde van sijn Hooghheijt in sulcken state te recontreeren, met tranen beteughden." VOC 1276 OB, Inkomen Briefboek Makassar 1671, fol. $710 a$.

199 "Bij verscheijdene gelegentheden heft sijn Hooght. In particuliere bijeencomste mij zijne adversiteijt getoont tegen de secte der Mahumetanen, amplecterende onse religie." VOC 1276 OB, Inkomen Briefboek Makassar 1671, fol. 748a.
} 
obstacle to Palakka's acceptance of Christianity was the doctrine of monogamy. It would be unsuitable for a king to have but one wife. ${ }^{200}$

As we have seen above, Speelman refrains from any moral judgements on the Arung Palakka's polygamy in the survey of his four wives, and the issue of polygamy does not concern Speelman in this context. But he accords a rather lengthy passage to the political implications of Palakka's speculations about Islam and Christianity with evident concern.

In addressing the High Government on the issue, Speelman is quick to dismiss any profound religious conviction in Palakka: "However much he [Palakka] professes his sympathies for Christianity, he understands next to nothing of it." ${ }^{201}$ Speelman had tried to enlighten Palakka, but with little success: "Much as I have, to the best of my ability, and in Malay too, from time to time tried to inform him of the general principles of it." ${ }^{202}$ It has all been to no avail, however, as Palakka in Speelman's eyes has problems with his attention and focussing, as often as not diverting the discussion to other topics. ${ }^{203}$ The argument is elaborated further: Palakka is distracted, and without an ability to differentiate between issues of relevance and irrelevance, with a preference for discussing matters of minor importance. ${ }^{204}$ Speelman's judgement of Palakka's intellectual capacity thus stands in stark contrast to his positive judgement of Karunrung's. But it is not primarily in intellectual terms that Palakka's religious concerns are viewed. If Palakka's thoughts on religion are superficial, a whim that should not be taken seriously in Speelman's eyes, what should be taken seriously is that if Palakka's religious thoughts came to light, they might jeopardise Palakka's prestige and position among his own people.

200 "allenlijcq wat swaermoedigh valt aensiende op het Christen huwelijcq, meenende, dat het voor een conincq te hard was een vrouwe te mogen hebben." VOC 1276 OB, Inkomen Briefboek Makassar 1671, fol. $748 \mathrm{a}$.

201 "Dogh evenwel, en schoon hij (als geseght) ons Christen gevoele wel beaengenaemde, soo noghans en verstaet hij daervan niet." VOC 1276 OB, Inkomen Briefboek Makassar 1671, fol. 748a.

202 "hoewel ick nar vermogen, en voor soo veel ick dat in ' $t$ Maleijts zeggen ende hem te verstaen conde, nu en dan in generale termen hem wel eenigh onderright hebbe gedaen." VOC 1276 OB, Inkomen Briefboek Makassar 1671, fol. 748a.

203 "Dogh hij is seer niet attentiff ofte opmerkende, niet alleen darin, maer aen voorts alle andere saecken." VOC 1276 OB, Inkomen Briefboek Makassar 1671, fol. 748a.

204 "seer vergeetelijcq, maer genegen tot discoersen van cleen belang." VOC 1276 OB, Inkomen Briefboek Makassar 1671, fol. 748a. 
Speelman makes it clear to the High Government that on several occasions he tried to warn against and lead Palakka away from his "path of folly." 205 His advice and instructions to Palakka was, he goes on, that Palakka keep his dislike of the Muslim faith a closed subject. ${ }^{206}$ Then, introduced first by what I take as a conventional concession to piety, in which Speelman holds forth that the spreading of the Christian faith is an ultimate duty, ${ }^{207}$ he goes on to stress that it was of still greater importance that the religious issue in the case of Palakka be handled with absolute discretion. ${ }^{208}$

In the actual communication between Speelman and Palakka, this message must have taken the form of a non-negotiable order rather than as friendly advice. Speelman's account of his final instructions to Palakka on the matter cannot be understood in any other way: "bordering on the offensive, Palakka has been instructed not to talk to nor discuss such matters with anyone, to preempt any conflict."209

The consideration in Palakka's reflections on religion is that a local Company ally should not reveal thoughts that might be interpreted as contemplating converting to his European ally's religion. For his part, Speelman, tried to block any conversion out of considerations of political stability and preservation of an invaluable alliance. Speelman's handling of Arung Palakka's thoughts about conversion thus demonstrates an example of how secular political concerns took priority over religious missionary ones, which conforms to the Company rule. But the case also demonstrates a point of methodological significance in overseas diplomacy, namely that one should not underestimate the factor of agency.

For, from a counter-factual, hypothetical point of view, a disclosure of Palakka's toying with the idea of conversion might well have had the disastrous effects that Speelman feared, and broken the alliance with the Bugis. If the

205 "hoe dickmaels ick hem van die vodderij aff getrocken en vermaent hebbe." VOC 1276 OB, Inkomen Briefboek Makassar 1671, fol. 748a.

206 "dat hij best onthielde, 't geene tot naedeel van de voorsz: secte tusschen ons beijde werde bijgebraght." VOC 1276 OB, Inkomen Briefboek Makassar 1671, fol. 748a.

207 "en off wel ten hooghsten plicht zij, 't gelove Christ uijbreijden." VOC 1276 OB, Inkomen Briefboek Makassar 1671, fol. 748a-b.

208 "dat alsnogh sal moeten geschieden, want de saecke veel te teer om niet heel voorsightigh gehandelt werden." VOC 1276 OB, Inkomen Briefboek Makassar 1671, fol. 748b.

209 "Niettemin is hij daerin althoos geconfronteert benevens insinuatie, sich selve in dien deele aen niemant te verclaeren, tot vermijdinge van alle revolutie." VOC 1276 OB, Inkomen Briefboek Makassar 1671, fol. 748 b. 
alliance had broken, it might have changed the outcome of the campaign. Speelman's delicate handling of the problem was probably decisive in keeping the Bugis from falling out over this issue, and thus of equal importance to the success of the Company's venture. The incident at least goes to illustrate how delicate overseas diplomacy was, and how much instinct it took to conduct it successfully. This is not to say that all the Company's agents possessed Speelman's abilities. But to suggest that none of them did, or that cultural differences prevented all of them from acquiring such an intimate understanding of indigenous culture in South East Asia is wide off the mark and leaves the Company's diplomatic successes unexplained.

\section{Speelman's handling of the two obstacles and the diplomatic mode of empirical pragmatism}

Speelman's tackling of the succession procedure and Palakka's religious speculations form striking illustrations of how "big models" sometimes are inadequate at best when confronted with empirical facts at the level of micro-action. Both issues illustrate the kind of practical challenges that Speelman had to grapple with when dealing with his main ally. Even on a more general level it could be argued that this was what overseas alliance diplomacy was about, keeping an observant eye on seemingly trivial "details" that beneath the surface were of crucial importance.

Palakka stood in danger of losing his standing and prestige among the Bugis if his personal speculations on religious issues were made public, with potentially disastrous consequences. When Speelman managed to find a solution to the potential hazards, of both the succession and the religious conversion issues, and managed to manoeuvre himself into a clandestine personal negotiating position with Karunrung (although the outcome was unsuccessful), these achievements were definitely the result of Speelman's "cultural competence" and personality. Qualities that he somehow managed to "fit" into the local cultural matrix of politics.

\section{Section 4: The personal prowess argument}

Finally, there is one factor that in my mind probably was one of the most important in explaining Speelman's diplomatic success, regardless of how he 
acted towards friend or foe. If we keep in mind Speelman's admiration for Karunrung's positive attributes as well as his admiration for Arung Palakka's courage, we can establish a basic motto of Speelman's own values which may be summarised as: "Bold action by good sense." Bold action as an ideal would be compatible with local standards and it seems reasonable to argue that the indigenous elite understood Speelman as a man of extraordinary personal, if not charismatic power. If so he would fall in line with what $\mathrm{O}$. W. Wolters has designated as typical of South East Asian conceptions of power-legitimacy, namely charisma, ${ }^{210}$ and then understood as an ideal type in opposition to European "rational power legitimation."211

If, however, Speelman's reputation as a "man of prowess," was one of his greater assets in his diplomatic performance in Sulawesi, which there is reason to propose, such a proposition spoils the schematic simplicity of the Europe-South East Asia dichotomy of charismatic as opposed to "rational" conceptions of power. I have argued consistently in this chapter, and in this thesis in general, that this dichotomy is generally too simplistic. But, returning to the case in point here, if charisma was one of Speelman's assets, it was also put in force by his recognition of the nature of indigenous conceptions of state power and diplomacy. The two went together in Speelman's pragmatic, empirical diplomacy.

\section{Chapter conclusion}

Negotiations with local power holders on concrete issues formed the foundation of the Company's diplomatic edifice. The diplomatic treaty formed the top floor, the institutional formal level where specific negotiated agreements could be inscribed in writing and presented to the world as "forever binding." But a preoccupation with this level may delude us into drawing mistaken conclusions about "legal formalism," "Eurocentric bias," and the like as the predominant characteristic of the Company's overseas negotiations with local power holders, by overlooking that the basis of these respective treaty agreements was always personally conducted negotiations between local rulers and Company representatives. As we have seen, Speelman did not trust the

\footnotetext{
210 O. W. Wolters, History, Culture, and Region in Southeast Asian Perspectives (Singapore: SEAP, 1982), 9-10.

211 Ibid. 13.
} 
institutional arrangement by treaty to support the Company's hegemony in South Sulawesi alone. It had to be backed up by a military presence and the threat of sanctions. But still more important was the personal diplomacy that underlay alliance building.

Speelman's evaluation of his former Makassarese foes and Palakka and the Bugis allies gives us a glimpse into this agency level of overseas diplomacy. It demonstrates that the cornerstone of Speelman's diplomatic method was the personal bonds that could be established with potential or actual power holders. It also demonstrates that Speelman was working from a realist assumption in which personal ethics and moral standards were viewed as secondary compared with the Company's politico-diplomatic use-value. Establishing collaborative bonds with Karunrung was deemed "good," despite his moral deficiencies because the Company considered his political talents useful. Establishing a fixed procedure of succession in the event of Palakka's premature death, and preventing him from undermining his own legitimacy by going public with his religious thoughts, were "good" in the sense that they were necessary to pre-empt a problematic situation for the Company. Adequate reaction to such challenges had to be based on relatively precise assumptions and assessments of the personal qualities of rulers and members of the local power elite alike, as well as of the local political context and situation. Empirical pragmatism seems to be a relevant term for this kind of approach. 


\section{Thesis Conclusion}

In the introductory chapter, I pointed to positions that I held to be either misleading or incomplete when characterising the nature of the Company's diplomatic practice. In particular I disagreed with the proposition that VOC overseas diplomacy was structurally fixed in typical European conceptualisations. The General Instructions, not only those of 1650, but all of them bear witness to a sensitivity to the particulars of the overseas context, and the need to take these into account when interacting with local parties. The tenor in the general advice issued by the Directors in the Netherlands to the Company's agents overseas was thus not that one should follow European standards automatically, but that one should negotiate and accommodate on basis of pragmatic appraisals of the situation at hand.

The tripartite system of the Directors' manual for the Company's mode of interaction with Asian rulers built on a similar kind of pragmatism. It set up two general principles, first that the Company's monopoly in the Moluccas had to be protected at all costs, which in effect excluded symmetrical diplomatic relations with the smaller Moluccan polities. They were either subservient defenders of the Company monopoly, or enemies who had to be brought under control. But looking at the rest of the charter area, we find a second principle in which the choice of diplomatic mode was built on the Company's relative strength in relation to its respective Asian partners. Where there was parity of strength, or where the Company remained the weaker part, a rule of pragmatism and accommodation reigned as long as this approach did not compromise the Company's interests to an unacceptable degree.

My analysis of Batavia's diplomatic interaction with Makassar in its various aspects reveals pragmatism as key to the Company's diplomatic mode on site. Van Diemen got what he could get into the 1637 treaty not by dictating terms from the European legal canon but by bargaining with the Makassarese with the objective of setting down rules that would protect the Company's interests. In that respect, the two treating parties shared some basic understanding of what they were doing. The 1637 negotiations represented a bargaining over specific contract clauses, a tug of war over shared issues. 
The internal disagreement on whether to continue the war or conclude a peace in 1655 demonstrates that the Company was not a monolithic body as far as decisions over policy was concerned. Opinion was split in Batavia, and opposing political positions were argued, but the opposing positions in the Council of the Indies were both argued in terms of practical cost-benefit calculations that sought to assess the Company's best interests. The ends and framework of reasoning were shared; what the parties disagreed on was the means to achieve the optimal outcome for the Company. It should also be noted that legal aspects were considered secondary in these discussions.

This points towards principled pragmatism as the core characteristic of the Company's diplomatic practice. The break away from "soft diplomacy" that occurred with the disillusionment over the 1655 treaty signified a shift to a consistent realist conceptualisation of power politics that came to dominate Batavia's approach towards Makassar after 1655. All the same, there is an element of continuity involved. Both before and after 1655, the determining factor in policy decisions on Makassar lay in assessments of the Company's contextual opportunities and constraints. The shift after 1655 was determined by an appreciation of context, not by a pre-ordained structural mode of thinking.

Except for the 1655 treaty, with its particular background the formulations and contents of the respective contracts concluded with Makassar are all symptomatic of the pragmatic empirical approach: The clauses are consistently phrased in concrete and specific terms. The model of the form and contents of the treaties is more akin to a merchant contract than to a formal diplomatic treaty. It is also noteworthy that the treaties became increasingly detailed and specific after 1655 . This serves to underline the fact that if the Company's approach was empirical and pragmatic at the outset, it became increasingly more so as contact with Makassar intensified. It is thus simply wrong when Andaya, for one, argues that the treaties were unintelligible to the locals because of their abstract form; the reality was quite the opposite. The treaties were made concrete and specific so that the locals could not find loopholes or ambiguities to exploit.

With its compendious information on local affairs, political and non-political alike, which supplied the Company with useful information that could help it preserve its dominance, Speelman's Notitie is an example of the Company's 
reliance on empirical data in the service of diplomacy, but by its case-specific and bottom-up mode of exposition it is also typical of the Company's empirical approach in general.

Another notable characteristic of the Notitie is Speelman's focus on personality traits as factors in diplomatic interaction. This might reflect an appreciation of a difference in the balance between the institutional and personal dimensions in Western and Asian diplomatic practice. If so, the emphasis on the personal dimension represents an accommodation of diplomatic strategy to the realities of the overseas context. Yet there are broader implications in Speelman's mode of exposition and perception.

Speelman's "diplomatic method" centres on his evaluation of the personal qualities of persons in power basically to know whom one should be on guard against or with whom one could form friendly ties. Sometimes, as in the case of Karunrung, both focuses applied. Considerations of context are subsidiary to an appreciation of personality traits, as his treatment of context focuses on which groups and dynamics in local hierarchies of power might be favoured or not. "Structure" understood as "political culture" or analyses of modes of power articulation in more generalised forms are nearly absent in Speelman's text, which is dominated by concrete and specific descriptions at the local political level. Read as a manual of overseas diplomacy, the Notitie is thus basically a case-focused, bottom-up, and agency-centred deliberation on alternative routes of diplomatic action. It is to a large degree a method I have applied in this thesis. How does it stand in relation to the historiography, and what is to be gained from it?

I started out by numbering five approaches to the understanding of the nature of seventeenth-century VOC diplomacy and the nature of the Company's interactions in Asia: the classical approach of the nineteenth and early twentieth centuries, characterised by a bias towards the political and military dimension of overseas expansion; Alexandrowicz's "system compatibility approach," which focuses on structural similarities between systems of international law in early modern Asia and Europe; and Andaya's opposing proposition of incompatibility advocated in his structural cultural approach, an idea that also popped up in Arasaratnam's refutation of Paulusz. I also included Somers as a forth type, a "legalist-pragmatic approach" because of his stress on both legal and pragmatic considerations in the Company's diplomacy. Finally, I included Van Ittersum because she represents a broadening of the perspective by 
consistently putting the Company's diplomacy and treaty making in a wider historical and political context, and her proposition about the cynical nature of the Company's diplomacy.

I have primarily concentrated on refuting Andaya's propositions about the nature of VOC diplomacy as Eurocentric, and his propositions of structural misunderstanding in communications between Makassar and the Company. My counter-argument regarding the nature of the Company's diplomacy rests on a demonstration of the pragmatic orientation found in both the General Instructions from the Heeren XVII and in the Company's practice towards Makassar. As for the Makassarese, I have partly argued that Andaya's proposition rests on the assumption that they would apply the same model and approach towards an outsider like the Company as they would to a local ruler or state. The illogical assumption of this proposition is that it implies that the Makassarese accepted the Company as an integral part of the South Sulawesian states system, and all evidence points to the contrary. Neither does the evidence point towards an interpretation of CompanyMakassar communications as a structurally determined misunderstanding. Although their motives may have been different, the Company and Makassar were taking part in a communication in which they did understand each other's positions. Functional communication did take place.

Having rejected Andaya's structural approach and propositions, where does that leave me in relation to the other positions in the historiography? First of all, it almost goes without saying that I find the classical approach of the nineteenth and early twentieth centuries too narrowly focused on the formal aspects of international law and the legal dimension of treaty making. This is a criticism that to my mind also partly applies to more modern scholars like Somers. In these cases, it is not so much the arguments advanced that I object to, but the restricted perspective of the analysis. I propose that the picture needs to be filled in with more reflection on the Company's diplomatic practice in its extra- legal dimensions. One line of research that seems to offer itself from such an assumption is a complementary proposition to Alexandrowicz's thesis about the increasing similarity of Asiatic and Western modes of diplomacy because of a tendency towards "westernisation" in Asia, namely that one should also look for incorporations of "Asian elements" or modes of accommodation to local Asiatic modes in the Company's diplomatic practice. Within this line of research, one should specifically look for the Company's mode and criteria of selection for the incorporation of local features. 
As for propositions about the cynical nature of the Company's diplomatic mode as formulated by Van Ittersum, I suggest that she overplays her hand. Her evaluation must be modified because it neither heeds nor covers the complex nature of the Company's approach as a whole. For one, such elements as the role of emotional factors such as pride and prestige are neglected. Besides, if we claim that the Company acted cynically in the case of Makassar, it did so for a reason. Cynicism sprang from the High Government's diminishing trust in Hasanuddin's sincerity in honouring the terms of the treaty and in its observation that the king of Makassar continued to harbour aggressive plans for the Spice Islands. Perhaps "contextual cynicism" might be a more precise term for the High Government's attitude after 1655. But the cynicism was not there from the beginning. The negotiations for a treaty in 1637 took place within a symmetrical framework, and, judged by the evidence, with serious intentions on both sides. As for Maetsuyker's rationale for favouring negotiations instead of continuing the war in 1655 , his attitude seems to have been more idealistic, understood as having "good faith in," than cynical, given his sincere belief that the new treaty would guarantee stable relations with Makassar once and for all. Cynicism only increased as this belief waned. And even then, to my mind, it was not cynicism pure and simple.

Batavia's diminishing trust in Hasanuddin went hand in hand with a change in its appreciation of negotiation and war as instruments of diplomacy. Relative emphasis and preference were reversed and inverted. Negotiations were perceived in increasingly tactical terms, and treaty terms were formulated in increasingly practical detail. Possibly this move could be regarded as a general trend that paralleled the Company's increased power in the seventeenth century. But there is one factor that should not be overlooked in this context, namely that there might have been an element of idealism, here understood as the "pursuit of higher goals and ideals" involved in this development, as well.

As we have seen, a sense of pride and concerns of prestige were already evident in the General Instructions. If there was a sense of self- confidence and pride in the Company and its achievements, pursuing the Company's interest with uncompromising faith may also have contained the belief that it should be done by fair means, or be conducted according to certain moral standards. "Sticking to your promises" might well have been part of this "moral package," and not just a tricky means of extortion. If so, we are close to a moral idealistic 
perception of diplomacy. In such a perspective, the belief that pacta sunt servanda acquires moral-idealistic qualities.

Another weakness of Van Ittersum's work is its limited relevance for generalisations about the Company's mode of diplomacy. Van Ittersum's case is the Moluccas, an area in which the Company held a special position and followed a special policy necessitated by its commitment to defend and protect its policy positions. She also focuses on the legal "child prodigy" Hugo Grotius, who was enlisted as a lawyer to defend the Company to the extent of setting even crooked affairs straight. He was the outstanding example of a legal nit-picker. But, as the Makassar case shows, in places where the Company neither could dictate nor manipulate outcomes, diplomatic interaction was a much more complex affair than could be conceived of in legal terms alone.

If this was true for Makassar up to 1667, it was all the more truer for the larger mainland states outside the Indonesian archipelago. In fact, the area outside the Spice Islands proper, an entity that falls outside Van Ittersum's selection of cases, forms the larger mass of the Company's contact and interaction points. Here one-sided Company manipulation and legal trickery did not offer itself as a viable option. Diplomacy had to be more complex by virtue of the complexity of context, and the Company's weaker position in it.

It follows from the above that I believe one does well to steer clear of absolute dichotomous propositions like Andaya's regarding the Company's and local modes of diplomacy. One does better in looking for where there seem to have been compatibilities and where there were contrasts at a lower level of analysis. Grand models tend to reify themselves instead of offering historical explanation. On the other hand, analysis at the level of agency might offer more solid ground for constructing analytical models. Have I offered such a model here? If I have, I stand in debt to the historiography. If there hadn't been Stapel's thesis on the Company and Makassar, I could never have written this study. Likewise, if Andaya had not formulated his original propositions, I would not have been able to formulate my own angle of approach.

I even probably could not claim full originality to my tentative formulations about how to proceed with further research in the field, because my propositions to a large degree are in line with Speelman's mode in the Notitie, namely to analyse the diplomatic interaction bottom- up from an agency perspective, and to point out how the actions were conditioned and modified by context. Only on this foundation will it be sound to infer structural 
implications that Speelman himself admittedly avoids. I have only argued a middle ground proposition, namely that the Company's mode of diplomatic interaction towards Makassar basically seems to have been determined by a principled pragmatism.

One fundamental question must be addressed at the end. Based as my discussion is on one particular case, Makassar, how can I argue that it also serves to tell us something about the general nature of the Company's diplomacy? On the one hand, it can be argued that to advance a general proposition I should point to a selection of cases, and not restrict myself to only one. On the other hand, general propositions can be, and are, supported by my one case. I shall demonstrate this by my proposition about principled pragmatism.

Pragmatism as the general key to diplomatic performance outside the Company's possessions in the Moluccas is laid down in the General Instructions. As I have shown, it is also a common denominator in Batavia's performance of diplomacy towards Makassar. Why may we assume that this was a general trait in the Company's diplomatic practice towards Asian princes and rulers in the charter area? Simply because the Company's pragmatism rested on the overseas context, or more precisely, the realisation by the Company from the Directors to the Council of the Indies that they could not go about as they pleased regarding relations with most of the Asian rulers. It would neither work nor pay, neither politically nor commercially. Practical considerations meant that the Company could not behave like an idiot abroad, as it knew it could not afford to. This logic worked for the Company's approach towards Makassar until the Company realised that it could no longer afford not to intervene decisively. But when it did, it was because circumstances offered an opportunity to do so. The underlying logic of pragmatic considerations of opportunity as a guide to action was the same for the other states and rulers in the charter area. Mistakes and corrections were made within this general approach, as we have seen in the case of Makassar, but this does not alter the fact that the pragmatic approach constituted the general rule outside the Moluccas. Makassar constitutes a somewhat special case in that sample, but still a case. 



\section{Bibliography}

\section{Primary Printed Sources}

Chijs, J.A. van der, H.T. Colenbrander, and J. de Hullu (eds.), Daghregister gehouden in het Casteel Batavia, vant passerende daer ter plaetse als over geheel Nederlandts-India (31 Vols. The Hague: Martinus Nijhoff, 1887-1931).

Coolhaas, W.Ph., J. van Goor, and H.K. s'Jacob (eds.) Generale Missiven van GouverneursGeneraal en Raden aan Heren XVII der Verenigde Oost-indische Compagnie (13 Vols. The Hague: Martinus Nijhoff, 1960 - 2007).

Heeres, J. E., and F.W. Stapel (eds.), Corpus Diplomaticum Neerlando- Indicum:

Verzameling van Politieke Contracten en verdere Verdragen door de Nederlanders in het Oosten gesloten, van Privilegiebrieven, aan hen verleend, enz. (3 Vols., 's Gravenhage: Martinus Nijhoff, 1907-1934).

Jonge, J.K.J. de, M.L. Deventer, van, and others (eds.) De opkomst van het Nederlandssch gezag in Oost-Indië, Verzameling van onuitgegeven stukken uit het Oud-Koloniaal Archief (13Vols., s Gravenhage: Martinus Nijhof, '1862 - 1909).

Mijer, P., Verzameling van Instructiën, ordonnanciën en reglementen voor de regering van Nederlandsch Indië (Batavia: Lands-drukkerij, 1848)

Speelman, Cornelis, Notitie dienende voor eenen corten tijt en tot nader last van de Hooge Regeeringe op Batavia, tot naarrigtinge van de Onderkoopman Jan van den Oppijnen, bij provisie gesteldt tot Opperhooft en Commandant in 't Casteel Rotterdam, op Maccasser, en van den Capitain Jan Fransz; als hoofd over de Militie, mitsgaders die van den Raadt, anno 1669. VOC 1276 OB, Inkomen Briefboek Makassar 1671, f 684 - 1007, typed manuscript undertaken by W.Ph. Coolhaas and Dr. H.J. de Graaf in 1949 - 50, at the KITLV (Nr. H 802)

Stapel (ed), Pieter van Dam, Bescryvinge van de Oostindische Compagnie, derde boek, 'S-Gravenhaage, Martinus Nijhoff, 1943.

\section{Secondary Literature}

Alexandrowicz, C.H., An Introduction to the History of the Law of Nations in the East Indies, (Oxford: Clarendon Press, 1967).

Andaya, Leonard, The Heritage of Arung Palakka, (The Hague: Verhandelingen van het Instituut voor Taal-, Land- en Volkenkunde, 91, 1981).

Andaya, Leonard, "Treaty conceptions and misconceptions", Bijdragen tot de Taal-, Land-en Volkenkunde 134 (1978), no: 2/3 Leiden, 275 - 295. 
Anderson, M.S., The Rise of Modern Diplomacy 1450-1919, (London, New York: Longman 1993).

Arasaratnam, S, “J.H.O. Paulusz on the Westerwolt treaty in Ceylon: a rejoinder, Bijdragen tot de Taal-,Land-, en Volkenkunde, Deel 138- II/III, 191 - 205.

Barendse, René, The Arabian Seas 1640-1700, (Leiden: CNWS, 1998).

Basset, D.K., "English Trade in Celebes, 1613-1677", Journal of the Malaysian Branch of the Royal Asiatic Society, 31/1 1958, 1-39.

Black, Jeremy, A history of Diplomacy, (London: Reaktion, 2010).

Boxer, C.R., The Dutch Seaborne Empire, 1600 - 1800, (London: Hutchinson, 1965).

Boxer, C.R. Francisco Vieira de Figueiredo: A Portuguese Merchant- Adventurer in South East Asia, 1624-1667, Verhandelingen, KITLV, 52, ('S-Gravenhage-Martinius Nijhoff, 1967).

Blussé, Leonard, Tussen Geveinsde Vrienden en Verklaarde Vijanden, (Amsterdam: Koninklijke Nederlandse Akademie van Wetenschappen, 1999).

Blussé, Leonard and Jaap de Moor, Nederlanders Overzee: De eerste vijfig jaar 1600-1650, (Franeker: Uitgeverij T. Wever B.V, 1983).

Cense, A.A. "Eenige aantekeningen over Makassars-Boeginese geschiedschrijving" Bijdragen tot de Taal-, Land-, en Volkenkunde, CVII (1951), 42-60.

Clulow, Adam, The Company and the Shogun: The Dutch Encounter with Tokugawa Japan, (New York: Columbia University Press, 2014).

Cummings, W., "The Melaka Malay diaspora in Makassar, c. 1500-1669", Journal of the Malaysian Branch of the Royal Asiatic Society 66 (2): 107-122; June 1998.

Cummings, W., Making Blood White: Historical Transformations in Early Modern Makassar. (Honululu: University of Hawai'I Press, 2002.

Dijk, L.C.D. van, Neerlands vroegste betrekkingen met Borneo, den Solo-Archipel, Cambodja, Siam en Cochin-China (Amsterdam: J.H. Scheltema, 1862.

Emmer, Piet and Gommans, Jos, Rijk aan de rand van de wereld: de Geschiedenis van Nederland overzee, 1600-1800, (Amsterdam: Bakker, 2012).

Gaastra, Femme S., "Competition or collaboration? Relations between the Duct East India Company and Indian Merchants around 1680", in: Sushil Chaudhuri and Michel Morineau (eds.), Merchant Companies and Trade: Europe and Asia in the Early Modern Era, (Cambridge: Cambridge University Press, 1999).

Goor, Jurrien, van, De Nederlandse Koloniën: Geschiedenis van de Nerderlandse expansie 1600 - 1975, (Bilthoven: Sdu Uitgevers, (1994), 1997).

Goor, Jurrien, van, Jan Kompenie as Schoolmaster: Dutch Education in Ceylon 1690-1795, (Groningen: Wolters Noordhoff, 1978).

Goor, Jurrien, van, Kooplieden, predikanten en besturders oversee: beeldvorming en plaatsbepaling in een andere wereld, (Utrecht: HES Uitgevers, Utrecht, 1982).

Goor, Jurrien van (ed), Trading companies in Asia: 1600-1830 (Utrecht : HES Uitgevers, 1986). Goor, Jurrien van, Indische Avonturen: Opmerkelijke ontmoetingen met een andere wereld (den Haag: Sdu Uitgevers, 2000). 
Goor, Jurrien, van, Prelude to Colonialism: The Dutch in Asia, (Hilversum: Uitgeverij Verloren, 2004).

Goor, Jurrien van, Jan Pieterszoon Coen,1587-1629 : koopman-koning in Azië (Amsterdam: Boom, 2015).

Graaf, H.J. de, De geschiedenis van Ambon en de Zuid-Molukken, (Franeker: Wever, 1977).

De Graaf, H.J. De regering van Sunan Mangku-Rat I Tegal-Wangi, vorst van Mataram, 1646-1677, vol. I De ontbinding van het rijk, (Leiden: Verhandelingen van het Koninklijk Instituut voor Taal-, Land- en Volkenkunde, d. 33, 39 1961).

Guillot, C.; Ambary, Hasan Muarif.; Dumarçay, Jacques, The Sultanate of Banten (Jakarta: Gramedia Book Pub. Division, 1990).

Haan, F. de., Oud Batavia, 2nd revised Print (Bandung: Nix, 1935).

Hotz, A. “Inleiding”, i-c, Journaal der Reis van den Gezant der O.I Compagnie Joan Cunaeus Naar Perzië in 1651-1652 door Cornelis Speelman, (Leiden: Johannes Müller, 1908).

Huigen, Siegfried.; Jong, Jan L. de. The Dutch Trading Companies as Knowledge Networks (Leiden; Boston: Brill, 2010).

Hägerdal, Hans: Hindu Rulers, Muslim Subjects - Lombok and Bali in the Seventeenth and Eighteenth Centuries, (Bangkok: White Lotus Press, 2001).

Hägerdal, Hans; Lords of the land, lords of the sea: conflict and adaptation in early colonial Timor, 1600-1800 (Leiden: KITLV Press, 2012).

Ittersum, Martine J. van, Profit and Principle: Hugo Grotius, Natural Rights Theories and the Rise of Dutch Power in the East Indies 1595 - 1615, (Leiden: Brill 2006).

Jacobs, Els M., Merchant in Asia: The Trade of the Dutch East Company during the Eighteenth Century, (Leiden: CNWS Publications, 2006).

Jong, J.J.J. P. de, De Waaier van het Fortuin: Van handelscompagnie tot koloniaal imperium. De Nederlanders in Azië en de Indonesische Archipel 1595 - 1959, (Den Haag, Sdu Uigervers, 1998).

Kathirithamby-Wells, J. “Banten: A West Indonesian Port and Polity During the Sixteenth and Seventeenth Centuries, in Kathirithamby- Wells and John Villiers (eds.): The Southeast Asian Port and Polity, (Singapore: Singapore University Press, 1990, 107-127).

Knaap, Gerrit J. : "Crisis and failure : war and revolt in the Ambon Islands, 1636-1637", Cakalele Vol. 3 (1992), 1-25.

Knaap. Gerrit :«Kora-kora en kruitdamp - De Verenigde Oost-Indische Compagnie in oorlog en vrede in Ambon», in Knaap, Gerrit, and Teitler (eds.) De Verenigde Oost-Indische Compagnie tussen Oorlog en Diplomatie (Leiden: KITLV Uitgeverij, 2002), 257-279.

Knaap, Gerrit. Kruidnagelen en Christenen: De VOC en de bevolking van Ambon 16561696, tweede herziende druk (Leiden: KITLV Uitgeverij, 2004).

Korn, V. E. "Problemen der Makassaars-Boeginese samenleving", Bijdragen tot de Taal-, Land-en Volkenkunde, cviii, (1952), 17 - 35.

Leur, J. C. van, Indonesian Trade and Society, English translation, printed posthumously, (The Hague: Van Hove, 1955). 
Lieberman, Victor, "Local Integration and Eurasian Analogies: Structuring Southeast Asian History" Modern Asian Studies, Vol. 27, nr 3, July 1993, 568.

Lindblad, Thomas en Schrikker, Alicia (eds.): Het Verre Gezicht: Politieke en culturele relaties tussen Nederland en Azië, Afrika en Amerika, (Franeker: Uitgeverij Van Wijnen, 2011).

Locher-Scholten, Elsbeth en Rietbergen, (eds.) Hof en Handel Aziatische Vorsten en de VOC 1620 - 1720, (Leiden: KITLV, 2004).

Meersbergen Guido van, Ethnography and Encounter: Dutch and English Approaches to Cross-Cultural Contact in Seventeenth-Century South Asia, Unpublished PhD Thesis, History UCL, 2014.

Mostert, Tristan, "ick vertrouwe, dat de werelt haer op twee polen keert", de VOC, de rijksbestuurder van Makassar en een uitzonderlijk grote globe», in Lodewijk Wagenaar (ed): Aan de opverkant: Ontmoetingen in dienst van de VOC en WIC, 1600-1800 (Leiden: 2015), 77-96.

Nagtegaal, Luc, Riding the Dutch Tiger: The Dutch East Indies Company and the northeast coast of Java, 1680 - 1743, (Leiden: KITLV, 1996).

Noorduyn, Jacobus, Een Achtiende-Eeuwse Kronik van Wadjo - Buginese Historiografie, Proefschrift, Universiteit te Leiden, ('s Gravenhage, 1955).

Noorduyn, Jacobus, "The Wajorese merchants' community in Makassar», in: Roger Tol, Kees van Dijk and Greg Acciaioli (eds.), Authority and Entreprise among the Peoples of South Sulawesi, Verhandelingen, KITLV 188, (Leiden, KITLV PRESS, 2000), 95-121.

Noorduyn, J. De handelsrelaties van het Makassarse rijk volgens de Notitie van Cornelis Speelman uyt 1670, overdruk uit Nederlandse Historische Bronnen, (1983), p. 97-123 (Amsterdam: Verlooren, 1983).

Paulusz, J.H.O.: “The 1638 Westerwolt Treaty in Ceylon: Charges of Dutch Deceit Disproved”, Bijdragen tot de Taal-, Land-, en Volkenkunde, Deel 136-II/III, 321 - 352.

Pearson, M. N.: "The Political Economy of Merchant Empires - State Power and World Trade 1350 - 1750" in Tracy (ed.): The rise of merchant empires, long-distance trade in the early modern world, 1350-1750, (Cambridge; New York: Cambridge University Press, 1990).

Pelras, Christian, The Bugis, (Oxford: Blackwell Publishers, 1996).

Reid, Anthony, "A great seventeenth century Indonesian family: Matoaya and Pattingalloang of Makassar", Masyarakat Indonesia, 8/1, 1-28, 1981.

Reid, Anthony, "The Rise of Makassar", Review of Indonesian and Malaysian affairs, 17, 1983, 117-160.

Reid, Anthony, Southeast Asia in the Age of Commerce, 1450-1680, vol. 1: The Lands below the Winds, (New Haven: Yale University Press, 1988).

Reid, Anthony, Southeast Asia in the Age of Commerce, 1450-1680, vol. 2: Expansion and Crisis (New Haven: Yale University Press, 1993).

Reid, Anthony, "Islamization and Christianization in Southeast Asia: The Critical Phase, 1550-1650" in: Reid, Anthony ed., Southeast Asia in the Early Modern Era: Trade, Power and Beliefs (Ithaca, N.Y.: Cornell University Press, 1993). 
Reid, Anthony, "Pluralism and Progress in seventeenth-century Makassar", in: Roger Tol, Kees van Dijk and Greg Acciaioli (eds.), Authority and Enterprise among the Peoples of South Sulawesi, Verhandelingen, KITLV 188, Leiden, KITLV PRESS, 2000, 55-73.

Reid, Anthony "Early Modernity as Cosmopolis: Some Suggestions from Southeast Asia”, in Sven Trakulhum and Ralph Weber (eds.), Delimiting Modernities - Conceptual Challenges and Regional Responses, (Lexington Books, London 2015), 123-143.

Resink, G.J., Indonesia's History between the Myths - Essays in Legal History and Historical Theory, (The Hague: W. van Hoeve, 1968).

Ricklefs, M.C., A History of Modern Indonesia since 1300, Basingtoke, (London: Macmillan, 1993).

Rietbergen, P. J. A. N., De eerste Landvoogd Pieter Both (1568-1615) - Gouverneur van Nederlands-Indië (609-1614) Deel I, Deel II, (Zutphen: Walburg Pers, 1987).

Rietbergen, Peter and Locher-Scholten, Elsbeth, "Een dubbel perspectief; Aziatiasche hoven en de VOC, ca 1620 - ca 1720", in Rietbergen and Locher-Scholten (ed.) Hof en Handel, Aziatische vorsten en de VOC 1620-1720, (Leiden: KITLV Uitgeverij, 2004).

Roelofsen, C.G. "De Periode 1450-1713”, in A.C.G.M. Eyffinger, (red), Compendium volkenrechtsgeschiedenis, 2e druk, (Deventer: Kluwer, 1991, 43-109).

Roever, Arend de, De jacht op sandelhout, (Zutphen: Walburg Pers, 2002).

Rossum, Matthias van, Werkers van de Wereld; Globalisering, arbeid en interculturele ontmotingen tussen Aziatische en Europese zeelieden in dienst van de VOC, 1600-1800, (Hilversum: Verloren, 2014).

Somers, Jan A., De VOC als volkenrechtelijke actor, Proefscrift, Erasmus Universiteit Rotterdam, juni 2001.

Somers, Jan A., Nederlansch-Indië: Staatkundige ontwikkelingen binnen een koloniale relatie, (Walburg Pers, 2005).

Stapel, F. W. Het Bongaais Verdrag, Dissertation, (Leiden: Groningen [etc.]: Wolters ; 1922).

Stapel, F.W. Cornelis Janszoon Speelman, ('s- Gravenhage: Martinus Nijhoff, 1936).

Stapel, F. W. Geschiedenis van Nederlandsch Indië, Deel III (Amsterdam: Uitgevermaatchappij "Joost van der Vondel”, 1939).

Subrahmanyam, Sanjay, "Aspects of State Formation in South India and Southeast Asia, 1500 - 1650" Indian Economic and Social History Review, 23, 4 1986, 364-377.

Subrahmanyam, Sanjay, "Introduction", in Subrahmanyam, (ed.), An Expanding World, vol.8:Merchant Networks in the Early Modern World, Modern World", xiii-xxiii, (Aldershot, Great Britain: Variorum, 1996).

Talens, Johan, Een feodale samenleving in koloniaal vaarwater, Staatsvorming, koloniale expansie en economisch onderontwikkeling in Banten, West-Java (1600 - 1750), (Hilversum: Verloren, 1999).

Valentijn, Francois, Oud en Nieuw Oost-Indiën : vervattende een naaukeurige en uitvoerige verhandelinge van Nederlands mogentheyd in die gewesten, benevens eene wydluftige beschryvinge der Moluccos, Amboina, Banda, Timor en Solor, Java, en alle de eylanden onder dezelve landbestieringen behoorende : het Nederlands comptoir op Suratte, en de 
levens der groote Mogols: als ook een keurlyke verhandeling van 't wezentlykste dat men behoort te weten van Choromandel, Pegu, Arracan, Bengale, Mocha, Persien, Malacca, Sumatra, Ceylon, Malabar, Celebes of Macassar, China, Japan, Tayouan of Formosa, Tonkin, Cambodia, Siam, Borneo, Bali, Kaap der Goede Hoop en van Mauritius : te zamen dus behelzende niet alleen eene zeer nette beschryving van alles, wat Nederlands Oost-Indien betreft, maar ook 't voornaamste dat eenigzins tot eenige andere Europeërs, in die gewesten, betrekking heeft / Deel I, "Molukse Zaaken”, 286 - 323 and Deel II, "Ambonse Zaaken", 166 - 203. (Franeker : Van Wijnen, 2002, 1724).

Villiers, John, "Makassar: The Rise and Fall of an East Indonesian Maritime Trading State, 1512-1669", in: J. Kathirithamby-Wells \& John Villiers (eds.) The Southeast Asian Port and Polity, Rise and Demise, (Singapore: Singapore University Press, 1990), 143-156.

Vink, Markus P.M., "Images and Ideologies of Dutch-South Asian Contact: CrossCultural Encounters between the Nayak State of Madurai and the Dutch East India Company in the Seventeenth Century", Itinerario 21.2 1997.

Vos, Reinout, Gentle Janus, Merchant Prince: The VOC and the Tightrope of Diplomacy in the Malay World, (Leiden: KITLV, 1993).

Witteveen, Menno, Antonie van Diemen De opkomst van de VOC in Azïe, (Amsterdam: Pallas Publications, 2001).

Wolters, O. W., History, Culture, and region in Southeast Asian perspectives, (Singapore: Institute of Southeast Asian Studies, 1982). 